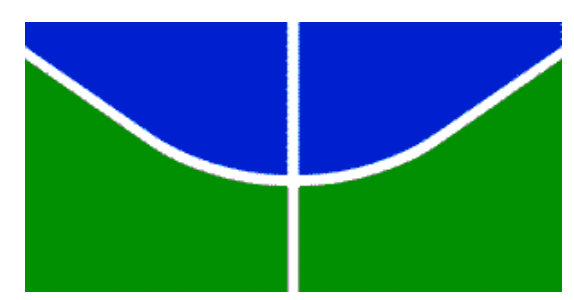

UNIVERSIDADE DE BRASÍLIA

INSTITUTO DE CIÊNCIAS BIOLÓGICAS

PROGRAMA DE PÓS-GRADUAÇÃO EM BIOLOGIA ANIMAL

PaOlin Rocio CÁCEREs VÉLEZ

\title{
NANOPARTICULAS DE PRATA NA PRESENÇA DE ÁCIDO HÚMICO EM MEIO AQUOSO: caracterização físico-química e avaliação toxicológica em modelo zebrafish (Danio rerio)
}


PaOlin Rocio CÁceres VÉLEZ

\section{NANOPARTICULAS DE PRATA NA PRESENÇA DE ÁCIDO HÚMICO EM MEIO AQUOSO: caracterização físico-química e avaliação toxicológica em modelo zebrafish (Danio rerio)}

Tese apresentada ao Programa de Pós-Graduação em Biologia Animal do Instituto de Ciências Biológicas da Universidade de Brasília, como parte dos requisitos para a obtenção do título de Doutora em Biologia Animal.

ORIENTADOR: PROF. DR. RICARDO BENTES DE AZEVEDO CO-ORIENTADOR: PROF. DR. CESAR KOPPE GRISOLIA 
Dedico esta tese à minha família, por acreditar em mim. Mãe, sev cuidado e dedicação foi que deram a esperança para seguir. Familiares e amigos, sua presença significou segurança e certeza de que não estive sozinha nessa caminhada. 


\section{Agradecimentos}

À minha mãe amada, motivação e motor da minha vida, por seu carinho que me acompanham onde eu estiver. Ao meu pai, por seu amor e conselhos sábios. Ao meu irmão José, pelas palavras de ânimo e pelas brincadeiras. À minha irmã Camila, pelas suas palavras de inocência e amor. À minha avó, que é uma mulher maravilhosa, meu exemplo, por seu amor e confiança em mim.

À minha família pelo apoio, paciência e carinho em particular à Efrén e à Anyela, por acreditarem em mim sempre e pela torcida para o sucesso deste trabalho.

Ao meu orientador, Professor Dr. Ricardo Bentes de Azevedo pelo carinho, acolhimento, por confiar e acreditar em minhas capacidades. Obrigada professor por me ensinar a enxergar mais longe!

Ao Professor Dr. Cesar Koppe Grisolia pela oportunidade de trabalhar em seu laboratório e pelo carinho.

Ao Dr. Sergio Moya e à Dra. Irina Estrela-Lopis pela oportunidade de trabalhar em seu laboratório, pela paciência, ensinamentos, confiança e apoio.

À Professora Dra. Sônia Báo por abrir as portas de seu laboratório para a realização de etapas deste estudo e aos alunos que fazem parte da equipe de trabalho do Laboratório de Microscopia pelo auxilio, ensinamentos e amizade.

Ao Professor Dr. Marcelo Henrique Sousa e ao Professor Dr. Paulo Eduardo Narcizo de Souza por me ajudar no esclarecimento das minhas dúvidas e pela paciência que tiveram para me transmitir seus conhecimentos.

Aos professores do Departamento de Genética e Morfologia (GEM) pelo carinho e pela ajuda durante o desenvolvimento do projeto.

À Dra. Maria Luiza Fascineli pela paciência, conselhos, ensinamentos, por estar sempre disposta a me ajudar e, especialmente, pela amizade ao longo desse tempo. Muito obrigada por me dar forças para continuar, por corrigir meus erros e por me motivar a ser uma melhor pesquisadora e pessoa! 
À Dona Zélia por sua amizade, confiança, simplicidade, organização e por contribuir para que tudo corra bem no laboratório. Muito obrigada pelo carinho e pelos conselhos, pois me ajudaram muito para superar situações difíceis.

Às minhas amigas Claudia, Karen, Ludimila e Wania pelo carinho e palavras de apoio quando mais precisei. Obrigada por me ajudar a manter a firmeza nesta caminhada.

Aos meus italianos preferidos, Luca e Desiré, pela companhia, apoio, carinho e por todos os maravilhosos momentos que compartilhamos. Obrigada por cuidar de mim!

Ao Alisson e aos meus colegas do laboratório de Nanotecnologia pela disponibilidade, carinho e amizade. Vocês sempre estarão no meu coração.

Aos meus amigos e colegas que fazem parte do Laboratório "Soft Matter Nanotechnology", do centro de pesquisa CICBiomaGUNE, especialmente à Elena e à Eliana, pelo carinho, disponibilidade, apoio e amizade durante meu estágio no laboratório.

À Universidade de Brasília pelo fornecimento da estrutura para a realização deste estudo.

À CAPES, ao CNPq e ao INCT de Nanobiotecnologia pelo apoio financeiro.

E a todas as pessoas que me apoiaram, auxiliaram e torceram por mim, contribuindo direta ou indireta no meu desenvolvimento pessoal e profissional. 
"Procure ser uma pessoa de valor, em vez de procurar ser uma pessoa de sucesso. O sucesso é consequência." 


\section{Resumo}

A produção e o amplo uso de nanomateriais como as nanopartículas de prata (AgNP) resultam no contato inevitável com o meio ambiente. Em ambientes naturais, as AgNP também podem formar sedimentos por adsorção com matéria orgânica, como o ácido húmico $(\mathrm{AH})$, alterando a sua biodisponibilidade e toxicidade. 0 objetivo deste trabalho foi avaliar o comportamento físico-químico das AgNP na presença do AH em diferentes meios aquosos (água ultrapura-MQ, água do sistema de manutenção do zebrafish-SIST e água reconstituída-REC) e avaliar os efeitos toxicológicos, em embriões e peixes adultos de zebrafish (Danio rerio), das AgNP na presença e ausência do AH. As AgNP com sem a presença de AH foram caracterizadas por espalhamento de luz dinâmico (DLS), microscopia eletrônica de transmissão (TEM), difração de raios X (DRX), espectroscopia no infravermelho por reflectância total atenuada (FTIR-ATR) e espectroscopia fotoeletrônica de raios X (XPS). Embriões ( $n=20 /$ grupo) com 2 horas pós-fertilização (hpf) foram expostos a $\operatorname{AgNP}(0 ; 0,25 ; 0,5 ; 1 ; 1,5 ; 2 ; 2,5 ; 3 ; 4,75 ; 6,5 ; 8,5$ e $10 \mathrm{mg} / \mathrm{L})$, com e sem a presença de AH $(20 \mathrm{mg} / \mathrm{L})$, para determinar a CL50 e avaliar o desenvolvimento embrionário durante 96 horas. Após 96 hpf, as larvas foram coletadas para analisar a incorporação de prata por ICP-MS. Por outro lado, peixes adultos ( $n=7 /$ grupo) foram expostos a 0,10, 20, 30, 40 e $60 \mathrm{mg} / \mathrm{L}$ de AgNP, com e sem AH (20 mg/L). Após $96 \mathrm{~h} \mathrm{de}$ exposição, foi determinada a CL50, os peixes adultos foram eutanizados a fim de coletar eritrócitos de sangue periférico para o teste de cometa, micronúcleo - MN e anormalidades nucleares - AN. As brânquias, fígado e intestino dos peixes foram coletados para análises histopatológicas por microscopia de luz e para avaliação da biodistribuição da prata por ICP-MS. Na análise por TEM observou-se que as AgNP têm formato variável e irregular, com diâmetro médio $26 \pm 16 \mathrm{~nm}$. A complexação do AH com as AgNP $(\mathrm{AgNP}+\mathrm{AH})$ foi observada por ATR-FTIR e corroborada por TEM e XPS. As análises de XPS indicaram também que a superfície das AgNP suspendidas em água MQ e SIST não foi oxidada $\left(\mathrm{Ag}^{0}\right)$ pela presença do $\mathrm{AH}$, mas a superfície das AgNP suspendidas em água REC com a presença do AH foi oxidada para $\mathrm{Ag}^{3+}$. A CL50 calculada para embriões de zebrafish expostos a AgNP foi de 1,19 mg/L AgNP, enquanto que para os expostos a AgNP na presença de AH a CL50 foi de 3,56 mg/L AgNP. As larvas expostas a AgNP apresentam fenótipos com atraso no desenvolvimento $(p \leq 0,05)$ em concentrações maior ou igual a $1 \mathrm{mg} / \mathrm{L}$ de AgNP, incluindo baixa viabilidade, edema 
generalizado, atraso na eclosão e absorção do saco vitelínico. Alterações no equilíbrio e edema cardíaco foram estatisticamente diferentes em concentrações acima de 0,25 e 0,5 $\mathrm{mg} / \mathrm{L}$ AgNP, respectivamente. As malformações observadas foram estatisticamente significativas em concentrações de 1 e 1,5 mg/L de AgNP. Em contraste, os embriões expostos a AgNP na presença de $\mathrm{AH}$ mostraram uma diminuição significativa na frequência de todas as alterações mencionadas anteriormente. Nos testes in vivo com zebrafish adultos, os valores da LC50 para peixes expostos a AgNP foi de 25,0 mg/L e para os grupos expostos a AgNP com AH foi de 40,56 mg/L. A fragmentação do DNA, avaliada pelo teste de cometa e $\mathrm{MN}$, não foi estatisticamente significativa $(\mathrm{p}>0,05)$ para os grupos expostos a 10, 20, $30 \mathrm{mg} / \mathrm{L}$ de AgNP, com ou sem a presença de AH, quando comparados com o grupo controle. Em contraste, o teste de AN mostrou diferenças significativas na frequência de células binucleadas. Apesar da presença de algumas alterações histológicas nas brânquias tais como hipertrofia de células de cloro e células epiteliais lamelares, levantamento do epitélio lamelar, hiperplasia de células mucosas, fusão lamelar e aneurismas, não houve diferenças estatisticamente significativas tanto para os peixes expostos às AgNP quanto para os expostos às $A g N P+A H$, quando comparado com o grupo controle. No fígado e intestino dos peixes expostos a AgNP e AgNP+AH não foram observadas alterações histológicas não obstante a análise por EDX indicou a presença de prata no lúmen intestinal. Embora os biomarcadores genotóxicos e histopatológicos não apresentaram diferenças significativas entre os grupos expostos $(\mathrm{AgNP}$ e $\mathrm{AgNP}+\mathrm{AH})$, o aumentos nos valores da CL50 do grupo AgNP+AH (quando comparada com a CL50 do grupo exposto a AgNP) pode estar relacionada com a presença do $\mathrm{AH}$ na água. Considerando os resultados obtidos no nosso estudo, a toxicidade e biodisponibilidade das AgNP pode diminuir em ambientes aquáticos contendo $\mathrm{AH}$, devido ao $\mathrm{AH}$ através dos seus grupos carboxílicos e fenólicos podem formar complexos fortes com as AgNP. Assim, a presença de ácido húmico em ambientes aquáticos aparece como um atenuador/remediador natural da água poluída com nanopartículas de prata.

Palavras-chave: Nanoecotoxicologia; nanopartículas de prata; ácido húmico; modificações na superfície das nanopartículas; biorremediação. 


\begin{abstract}
The extensive production and use of nanomaterials, such as silver nanoparticles (AgNP), result in their inevitable release into the environment which may harm some organisms. Moreover, nanoparticles can also form sediments by adsorption with natural organic matter (NOM), such as humic acid (HA), changing their bioavailability and toxicity. The aim of this work is to evaluate the physical-chemical behavior of AgNP in different aqueous medium (ultrapure water-UPW, zebrafish facility water-ZFW and zebrafish growing media-ZGM) and to assess their toxicological effects in embryos and adult zebrafish (Danio rerio). The study was carried out both in presence (AgNP+HA) and absence of HA in order to investigate the interaction this NOM on the AgNP. All materials were characterized by dynamic light scattering (DLS), transmission electron microscopy (TEM), x-ray diffraction (XRD), attenuated total reflectance infrared spectroscopy (FTIRATR) and X-ray photoelectron spectroscopy (XPS). In order to calculate the LC50 and to assess the embryo-larval toxicity, two hours post-fertilization (hpf) zebrafish embryos ( $n=20$ /group) were exposed during 96 hours to $\operatorname{AgNP}(0,0.25,0.5,1,1.5,2,2.5,3,4.75$, 6.5, 8.5, and $10 \mathrm{mg} / \mathrm{L})$ both with and without the presence of HA (20mg/L). After $96 \mathrm{hpf}$, zebrafish larvae were collected to analyze silver uptake. Additionally, adult fish were exposed for $96 \mathrm{~h}$ to $0,10,20,30,40$ and $60 \mathrm{mg} / \mathrm{L}$ of AgNP, with and without HA (20 $\mathrm{mg} / \mathrm{L}$ ). The LC50 was calculated and fish ( $n=7 /$ group) were euthanized to collect peripheral blood erythrocytes for comet assay, micronucleus (MN), and nuclear abnormalities (NA) tests. Gills, livers, and intestines were collected for biodistribution and histopathological assessment. TEM analysis showed that AgNP have variable and irregular shape, with an average diameter of $26 \pm 16 \mathrm{~nm}$. The complexation of HA with AgNP (AgNP+HA) was observed by FTIR-ATR analysis and corroborated by TEM and XPS. XPS assays also indicated that the surface of AgNP suspended in UPW and ZGM was not oxidized $\left(\mathrm{Ag}^{0}\right)$ by the presence of HA, but the surface of AgNP suspended in ZGM with the presence of HA was oxidized to $\mathrm{Ag}^{3+}$. The calculated LC50 for zebrafish embryos exposed to AgNP was $1.19 \mathrm{mg} / \mathrm{L}$, while the LC50 for AgNP+HA was $3.56 \mathrm{mg} / \mathrm{L}$. The larvae exposed to AgNP displayed developmental delay phenotypes $(p \leq 0.05)$ with concentrations of at least $1 \mathrm{mg} / \mathrm{L} \mathrm{AgNP}$, including lower viability, generalized edema, delays in hatching and yolk sac absorption. Alterations in body balance and cardiac edema were statistically different at concentrations above 0.25 and $0.5 \mathrm{mg} / \mathrm{L}$,
\end{abstract}


respectively. Observed malformations were statistically significants at 1 and $1.5 \mathrm{mg} / \mathrm{L}$ of AgNP. In contrast, embryos exposed to AgNP+HA showed a significant decrease in the frequency of the aformentioned alterations. The LC50 value for adult zebrafish exposed to AgNP was $25.0 \mathrm{mg} / \mathrm{L}$, while for groups exposed to AgNP+HA was $40.56 \mathrm{mg} / \mathrm{L}$. DNA fragmentation was not statistically significant $(\mathrm{p}>0.05)$ for groups exposed to $10,20,30$ $\mathrm{mg} / \mathrm{L}$ of AgNP with or without HA, when compared with the control group. In contrast, NA test showed significant differences of binucleated cells when compared with the control group. Although some gill histological alterations were observed (chloride cell and lamellar epithelial cell hypertrophy, lamellar epithelial lifting, mucosal cell hyperplasia, lamellar fusion, and aneurysms), there were no statistically significant differences for both AgNP and AgNP+HA when compared with the control group. EDX analysis showed the presence of AgNP in the intestinal lumen, but no histological changes were observed in the intestine and liver of fish exposed to AgNP and AgNP+HA. Considering the results obtained in our study, the toxicity and bioavailability of AgNP in zebrafish can decrease in environments with HA, since HA can form strong complexes between its carboxylic and phenolic groups with the AgNP. Thus, the presence of humic acid in aquatic environments appears as a natural attenuator/remediator of water polluted with silver nanoparticles.

Keywords: Nanoecotoxicology; silver nanoparticles; humic acid; nanoparticle surface modifications; bioremediation. 


\section{LISTA DE FIGURAS}

Figura 1. Classificação, aplicações e impacto para nanomateriais..........................................22

Figura 2. Incorporação celular de partículas nas células dos mamíferos..............................25

Figura 3. Caraterísticas dos nanomateriais e fatores que afetam a sua dissolução...........26

Figura 4. Mecanismos de incorporação de nanopartículas com diferentes formatos......28

Figura 5. Componentes básicos de um sistema de XPS monocromático. ..............................32

Figura 6. Diagrama de um processo fotoelétrico ........................................................................ 34

Figura 7. Componentes principais de um sistema de espectroscopia por dispersão de energia.

Figura 8. Características físico-químicas dos nanomateriais com os respectivos métodos/técnicas comumente utilizados.

Figura 9. Estrutura proposta para uma molécula típica de ácido húmico 53

Figura 10. Esquema do desenho experimental geral desse estudo.

Figura 11. Esquema do desenho experimental da caracterização físico-química dos materiais avaliados nesse estudo.

Figura 12. Esquema do desenho experimental dos testes in vivo. .64

Figura 13. Fotografias de micronúcleo e diferentes tipos de anormalidades nucleares em eritrócitos de sangue periférico de Danio rerio. .81

Figura 14. Caracterização das AgNP por MET. . .86

Figura 15. Difratograma de raios $X$ das nanopartículas de prata em pó . .86

Figura 16. Espectro XPS das AgNP. .87

Figura 17. Espectro Auger das AgNP. . .88

Figura 18. Caracterização do ácido húmico em pó por XPS . .89

Figura 19. Caracterização do ácido húmico em pó por XPS .89

Figura 20. Caracterização do ácido húmico em pó por FTIR. 90

Figura 21. Espectros UV/VIS do AH suspenso em água ultrapura .91

Figura 22. Análise das AgNP na presença de diferentes concentrações de $\mathrm{NaCl}$ .92

Figura 23. Diâmetro hidrodinâmico e potencial zeta das AgNP para diferentes concentrações de $\mathrm{NaCl}$ e pH neutro. . .93

Figura 24. Análise das AgNP na presença de diferentes concentrações de AH. .94

Figura 25. Diâmetro hidrodinâmico e potencial zeta das AgNP na presença de diferentes concentrações de $\mathrm{AH}$ e pH neutro .95 
Figura 26. Micrografias eletrônicas de transmissão representativas das AgNP na presença de $\mathrm{AH}$ em diferentes concentrações às 6 e 24 horas após sonicação.........95

Figura 27. Valores do diâmetro hidrodinâmico das AgNP na presença de $\mathrm{AH}$, em água MQ, REC e SIST

Figura 28. Valores do potencial zeta das AgNP na presença de $A H$, em água $M Q$, REC e SIST.

Figura 29. Valores do diâmetro hidrodinâmico e potencial zeta das AgNP na presença de AH, em água MQ, REC e SIST. .98

Figura 30. Micrografias eletrônicas de transmissão das AgNP com e sem a presença de AH, após 96 horas da sonicação. . .99

Figura 31. Análise por ATR-FTIR do AH adsorvido no filme de AgNP 100

Figura 32. Espectros XPS das amostras de AgNP suspendidas em água MQ.. 102

Figura 33. Espectros XPS das amostras de AgNP suspendidas em água REC.. 103

Figura 34. Espectros XPS das amostras de AgNP suspendidas em água SIST. 104

Figura 35. Parâmetro Auger calculado para as amostras de AgNP em água MQ, SIST e REC com a presença de AH. 105

Figura 36. Espectros XPS das amostras de AgNP, dispersas em água MQ com AH obtidos às $0,24,48$ e 96 horas após sonicação.

Figura 37. Espectros XPS das amostras de AgNP, dispersas em água REC com AH obtidos às 0, 24, 48 e 96 horas após sonicação 108

Figura 38. Espectros XPS das amostras de AgNP, dispersas em água SIST com AH obtidos às $0,24,48$ e 96 horas após sonicação.

Figura 39. Espectros XPS das amostras de AgNP dispersas em diferentes meios aquosos com AH, obtidos às 96 horas após sonicação.

Figura 40. Espectros XPS das amostras de AgNP dispersas em diferentes meios aquosos com AH, obtidos às 96 horas após sonicação.

Figura 41. Quantificação dos íons de prata liberados na água a partir de diferentes concentrações de AgNP com e sem a presença de AH.

Figura 42. Quantificação dos íons de prata liberados na água a partir da concentração de AgNP, com e sem a presença de AH, nos tempos 0, 24, 48 e 96 horas

Figura 43. Concentração letal 50\% das AgNP e das AgNP na presença de AH às 96 horas após fertilização. 
Figura 44. Avaliação do desenvolvimento embrio-larval durante 96 horas da fertilização mediante a exposição de AgNP, AH e AgNP+AH. 118

Figura 45. Imagens representativas dos organismos expostos durante 96 horas às AgNP, com e sem a presença de $\mathrm{AH}$ 119

Figura 46. Micrografias eletrônicas de varredura de organismos expostos às AgNP, com e sem a presença de AH, após 96 horas da fertilização.

Figura 47. Imagens representativas dos organismos expostos às AgNP com e sem a presença de $\mathrm{AH}$.

Figura 48. Prata incorporada nos organismos durante 96 horas de exposição às AgNP com e sem a presença de $\mathrm{AH}$..

Figura 49. Concentração letal 50\% das AgNP em adultos de zebrafish após exposição aguda.

Figura 50. Fragmentação no DNA em eritrócitos de peixes expostos a AgNP com e sem a presença de $\mathrm{AH}$ 126

Figura 51. Índice histopatológico total para brânquia de Danio rerio 129

Figura 52. Cortes longitudinais de filamentos branquiais de Danio rerio. 130

Figura 53. Micrografias representativas de fígado e intestino de Danio rerio de diferentes grupos experimentais.

Figura 54. Micrografias eletrônicas de varredura de intestino de Danio rerio. 132

Figura 55. Concentração de prata no intestino, fígado, rim, brânquia e músculo dos peixes expostos às AgNP com e sem a presença de $\mathrm{AH}$ 


\section{LISTA DE TABELAS}

Tabela 1. Técnicas de caracterização físico-química aplicáveis a sistemas nanoparticulados. 30

Tabela 2. Técnicas aplicáveis para análise de superfícies de nanomateriais 39

Tabela 3. Grupos experimentais considerados para avaliação da toxicidade no desenvolvimento embrio-larval mediante a exposição de AgNP, AH e AgNP+AH...75

Tabela 4. Grupos experimentais considerados para avaliação da toxicidade em peixes adultos mediante a exposição de $\mathrm{AgNP}, \mathrm{AH}$ e $\mathrm{AgNP}+\mathrm{AH}$ . .78

Tabela 5. Alterações histológicas em brânquias, fígado e intestino, classificadas segundo o estadiamento.. .83

Tabela 6. Caracterização da água MQ, REC e SIST por ICP-MS. .85

Tabela 7. Parâmetro Auger calculado para as amostras de AgNP em água MQ, REC e SIST nos tempos 0, 24, 48, e 96 horas após sonicação. 105

Tabela 8. Síntese dos resultados obtidos na avaliação do desenvolvimento embrio-larval durante 96 horas da fertilização mediante a exposição de AgNP 120

Tabela 9. Síntese dos resultados obtidos na avaliação do desenvolvimento embrio-larval durante 96 horas da fertilização mediante a exposição de AgNP+AH. 121

Tabela 10. Ocorrência de mortalidade e sinais clínicos observados nos peixes adultos expostos às AgNP.

Tabela 11. Ocorrência de mortalidade e sinais clínicos observados nos peixes adultos expostos ao $\mathrm{AH}$ e às $\mathrm{AgNP}+\mathrm{AH}$.

Tabela 12. Micronúcleos e anormalidades nucleares observadas en eritrócitos de sangue periférico de peixes (Danio rerio) expostos a AgNP, com e sem a presença de $\mathrm{AH}$.

Tabela 13. Alterações histológicas encontradas nos peixes expostos durante 96 horas a AgNP.

Tabela 14. Alterações histológicas encontradas nos peixes expostos durante 96 horas a $\mathrm{AgNP}+\mathrm{AH}$. 128 


\section{Lista De Abreviaturas e Siglas}

A Aneurisma

AN Alterações/Anormalidades Nucleares

AgNP Nanopartículas de prata

AgNP+AH Nanopartículas de prata na presença de ácido húmico

AH Ácido Húmico

ASTM "American Society for Testing and Materials"- Sociedade Americana para testes e materiais

ATR-FTIR Espectroscopia de Reflexão Total Atenuada no Infravermelho com Transformada de Fourier

AV Alto Vácuo

AVMA "American Veterinary Medical Association"- Associação médica americana de veterinária

B Células com Broto

BB Células com núcleo "Blebbed"

BE Bordadura em Escova

BN Células Binucleadas

CC Células Caliciformes

CL50 Concentração Letal $50 \%$

DE Descolamento do Epitélio lamelar

DH Diâmetro Hidrodinâmico

DLS "Dynamic Light Scattering"- Espalhamento dinâmico de luz

DM Dano Moderado

DNA “Deoxyribonucleic acid"- Ácido desoxirribonucleico

DRX Difração de Raios-X

DT Dano Total

E Estádio

ECS Epitélio Colunar Simples

EDS "Energy Dispersive x-ray"- Energia dispersiva de raios $\mathrm{x}$

EEC "European Economic Community" - Comunidade econômica europeia

EL Edema Lamelar

EPA "Environmental Protection Agency"- Agência de proteção ambiental 
ESCA Espectroscopia Eletrônica para Análise Química

FET "Fish Embryo Acute Toxicity" - Toxicidadeaguda em embriões de peixe

FL Fusão Lamelar

FpL Hipertrofia de células do epitélio lamelar

FT $\quad$ Fator de Importância

FTIR "Fourier transform infrared spectroscopy" - Espectroscopia no

infravermelho com transformada de fourier

H Hepatócitos

HpC Hipertrofia de células de Cloreto

hpf "Hours Post Fertilization"- Horas após a fertilização

HpM $\quad$ Hipertrofia de células Mucosa

HR-MET "High-Resolution Transmission Electron Microscopy" - Microscopia

eletrônica de transmissão de alta resolução

HsL Hiperplasia das células do epitélio Lamelar

HsM Hiperplasia das células Mucosas

ICP-MS "Inductively coupled plasma mass spectrometry" - Espectrometria de massa por plasma acoplado indutivamente

L L Lúmen

LB Células com núcleo "lobed”

MATC Concentração Tóxica Máxima Aceitável

MET Microscopia Eletrônica de Transmissão

MEV Microscopia Eletrônica de Varredura

MN Micronúcleo

MQ Água deionizada

MT Materiais Testados

NCL "Nanotechnology Characterization Lab" - Laboratório de Caracterização de Nanotecnologia

NT Celulas com nucleo "notched"

NTA "Nanoparticle tracking analysis" - Análise de rastreamento de nanopartículas

OECD "Organisation for Economic Co-operation and Development" - Organização para a Cooperação e Desenvolvimento Econômico

PEG Polietilenoglicol 
PVP Polivinilpirrolidona

PZ Potencia Zeta

REC Água Reconstituída

S Sinusóides

SIST Água do sistema de manutenção dos peixes zebrafish

UAV Ultra-Alto Vácuo

US EPA Agência de Proteção Ambiental dos Estados Unidos

USP "United States Pharmacopeia" - Farmacopéia dos Estados Unidos

UV-Vis $\quad$ Espectroscopia no Ultravioleta Visível

V Veia central

XPS "X-ray photoelectron spectroscopy" - Espectroscopia fotoeletrônica de raios $\mathrm{X}$ 


\section{SUMÁRIO}

INTRODUÇÃO.

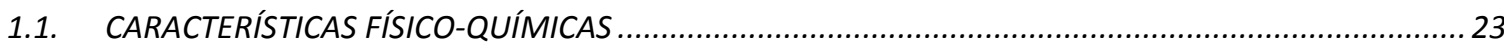

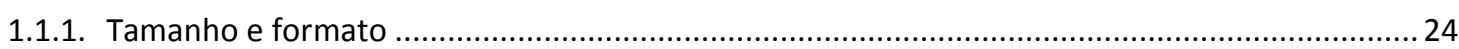

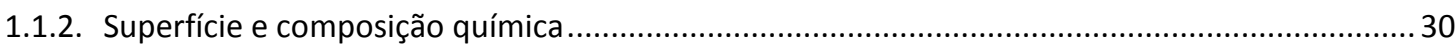

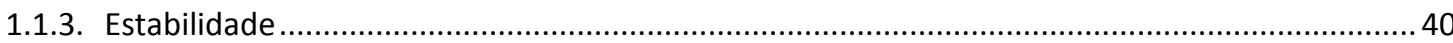

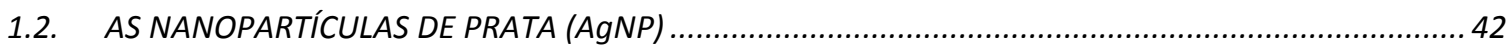

1.3. AS NANOPARTÍCULAS DE PRATA EM AMBIENTES AQUÁTICOS ....................................................

1.3.1. Efeitos Tóxicos das Nanopartículas de Prata em Organismos Aquáticos................................ 47

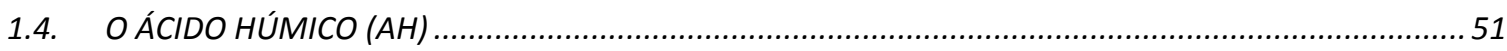

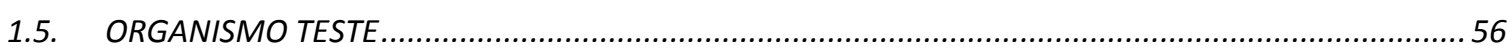

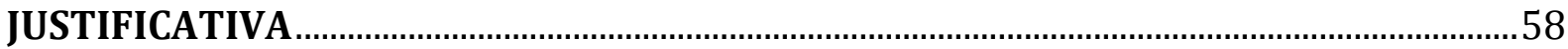

OBJETIVOS

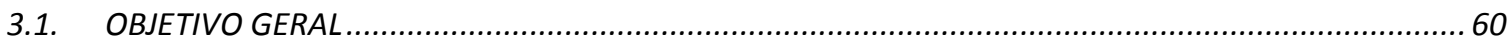

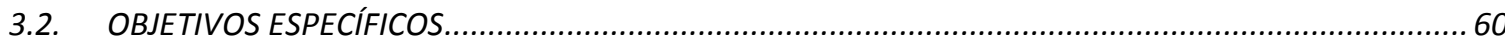

MATERIAIS E MÉTODOS

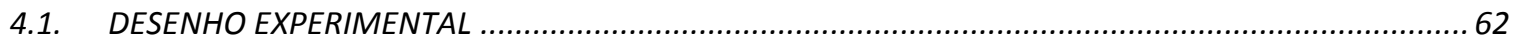

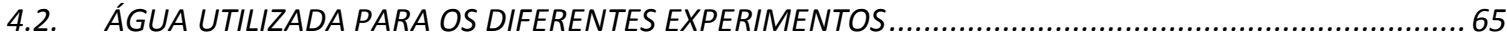

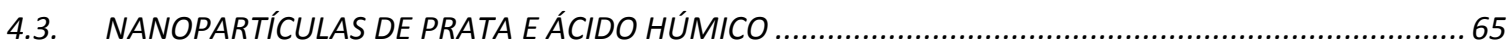

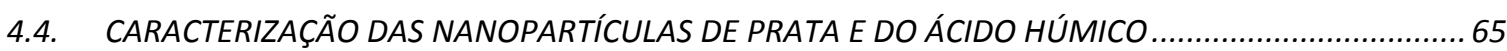

4.4.1. Caracterização da morfologia das nanopartículas de prata...................................................65

4.4.2. Estudo das características cristalinas das nanopartículas de prata .........................................66

4.4.3. Análise da composição química superficial das nanopartículas de prata e do ácido húmico......66

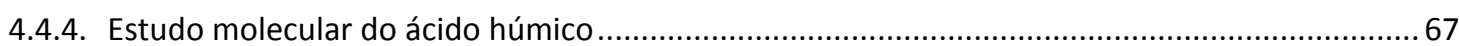


4.5.1. Estudo da estabilidade das nanopartículas em água deionizada em função de diferentes concentrações de $\mathrm{NaCl}$.

4.5.2. Estudo da estabilidade das nanopartículas de prata em água do sistema em função de diferentes concentrações de ácido húmico

4.5.3. Estudo comparativo da estabilidade das nanopartículas de prata para água deionizada, reconstituída e do sistema com concentração fixa de ácido húmico

\subsection{ADSORÇÃO E MODIFICAÇÕES DO ÁCIDO HÚMICO NA PRESENÇA DAS NANOPARTÍCULAS} DE PRATA

4.6.1. Análise das características moleculares....

\subsection{MODIFICAÇÕES NA SUPERFÍCIE DAS NANOPARTÍCULAS DE PRATA EM DIFERENTES MEIOS}

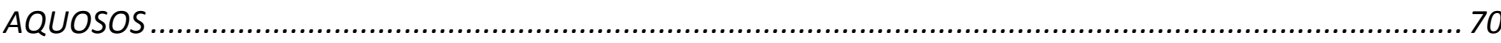

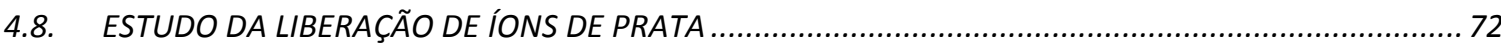

4.9. AVALIAÇÃO DA TOXICIDADE AGUDA, EM ZEBRAFISH, DE NANOPARTÍCULAS DE PRATA SUSPENSAS

EM ÁGUA SIST, COM E SEM A PRESENÇA DE ÁCIDO HÚMICO

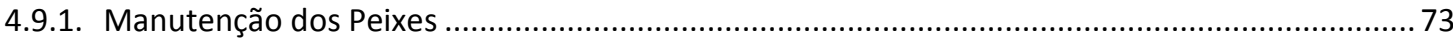

4.9.2. Avaliação da toxicidade aguda no desenvolvimento embrio-larval do zebrafish ...................... 74

4.9.3. Avaliação da toxicidade aguda em peixes zebrafish adultos .................................................... 77

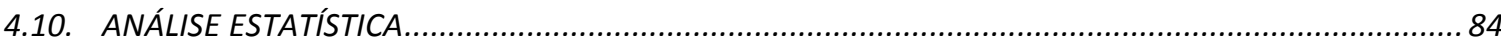

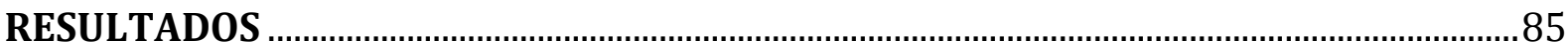

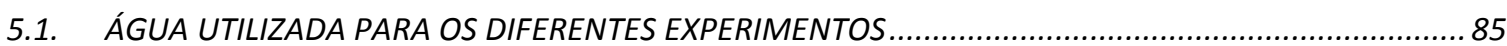

5.2. CARACTERIZAÇÃO DAS NANOPARTÍCULAS DE PRATA E DO ÁCIDO HÚMICO ................................85

5.3. ESTABILIDADE DAS NANOPARTÍCULAS DE PRATA EM DIFERENTES MEIOS AQUOSOS.................... 91

5.4. ADSORÇÃO E MODIFICAÇÕES DO ÁCIDO HÚMICO NA PRESENÇA DAS NANOPARTÍCULAS

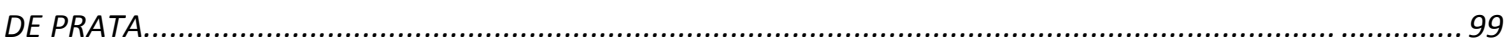

5.5. MODIFICAÇÕES NA SUPERFÍCIE DAS NANOPARTÍCULAS DE PRATA EM DIFERENTES MEIOS

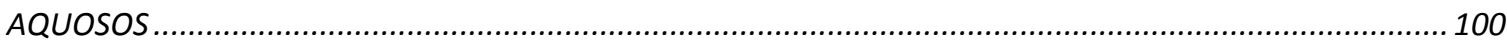

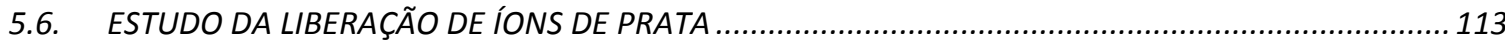


5.7. AVALIAÇÃO DA TOXICIDADE AGUDA, EM ZEBRAFISH, DE NANOPARTÍCULAS DE PRATA SUSPENSAS

EM ÁGUA SIST, COM E SEM A PRESENÇA DE ÁCIDO HÚMICO

5.7.1. Avaliação da toxicidade no desenvolvimento embrio-larval do zebrafish. 115

5.7.1. Avaliação da toxicidade em peixes zebrafish adultos 123

DISCUSSÃO 135

CONCLUSÕES 153

REFERÊNCIAS BIBLIOGRÁFICAS. 154

ANEXOS. 174

8.1. ANEXO A - DECLARAÇÃO DO COMITÊ DE ÉTICA NO USO DE ANIMAIS (CEUA). 174

8.2. ANEXO B - PARÂMETROS FÍSICO-QUÍMICOS DA ÁGUA NOS EXPERIMENTOS in vivo 175 


\section{1.}

\section{\NTRODUÇÃo}

Nanotecnologia, segundo a "International Organization for Standardization" (ISO TC 229, 2005), contempla o entendimento e controle da matéria e processos em nanoescala, tipicamente, mas não exclusivamente, abaixo de 100 nanômetros em uma ou mais dimensões, onde o aparecimento de fenômenos dependentes de tamanho permite novas aplicações. Além disso, abrange a utilização das propriedades dos materiais em nanoescala que são diferentes das propriedades dos átomos individuais, moléculas, ou dos materiais macroscópicos, criando materiais, dispositivos e sistemas melhores que exploram essas novas propriedades. Devido a isto, a nanotecnologia é um dos setores tecnológicos de rápido crescimento e com elevado impacto econômico com aplicações em diversas áreas, como cosmetologia, biomedicina, embalagens, biorremediação, tintas, revestimentos, eletrônicos, catálise, ciências dos materiais, entre outros (NEL et al., 2006; LÓPEZ-SERRANO et al., 2014).

Existem diversas classificações para os nanomateriais (Figura 1), as quais consideram diferentes parâmetros, entre eles: origem (natural ou antropogênica), composição química (inorgânica ou orgânica), formação (biogênicos, geogênica, antropogênica ou atmosférica), tamanho, formato, aplicações em pesquisa e indústria (LÓPEZ-SERRANO et al., 2014). Segundo a Agência de Proteção Ambiental dos Estados Unidos, os nanomateriais atualmente utilizados podem ser agrupados em quatro tipos principais, que incluem nanomateriais baseados em carbono, nanomateriais baseados em metais, dendrímeros e compósitos (U.S. EPA, 2007).

Entre os nanomateriais mais utilizados encontram-se lipossomas, dendrímeros, nanotubos de carbono, fulerenos, derivados do grafeno, óxidos de titânio, nanopartículas de óxidos de ferro, "quantum dots", nanopartículas poliméricas, 
nanopartículas de prata, ouro e platina (SINGH E NALWA, 2011; YANG et al., 2011; PRABHU E POULOSE, 2012; LING E HYEON, 2013; LIN et al., 2014), virossomas e hidrogéis (ETHERIDGE et al., 2013; LIN et al., 2014).

Existem sérias preocupações sobre os potenciais impactos ambientais e na saúde ocasionados pela exposição aos nanomateriais. E devido a isso, diferentes estudos têm sido realizados para avaliar a toxicidade dos nanomateriais, abrangendo principalmente, as interações de diferentes tipos de nanopartículas com organismos aquáticos (ARUOJA et al., 2009; LEE et al., 2012), plantas (MA et al., 2010; NAIR et al., 2010) e seres humanos (ZHAO et al., 2011). Estes estudos levaram ao surgimento da nanotoxicologia, uma disciplina emergente que tem como função principal a avaliação da segurança de produtos provenientes da nanotecnologia (OBERDÖRSTER et al., 2005; OBERDÖRSTER, 2010), contribuindo com o desenvolvimento econômico, a qualidade de vida e com a recuperação e proteção ambiental (OSTIGUY et al., 2009).

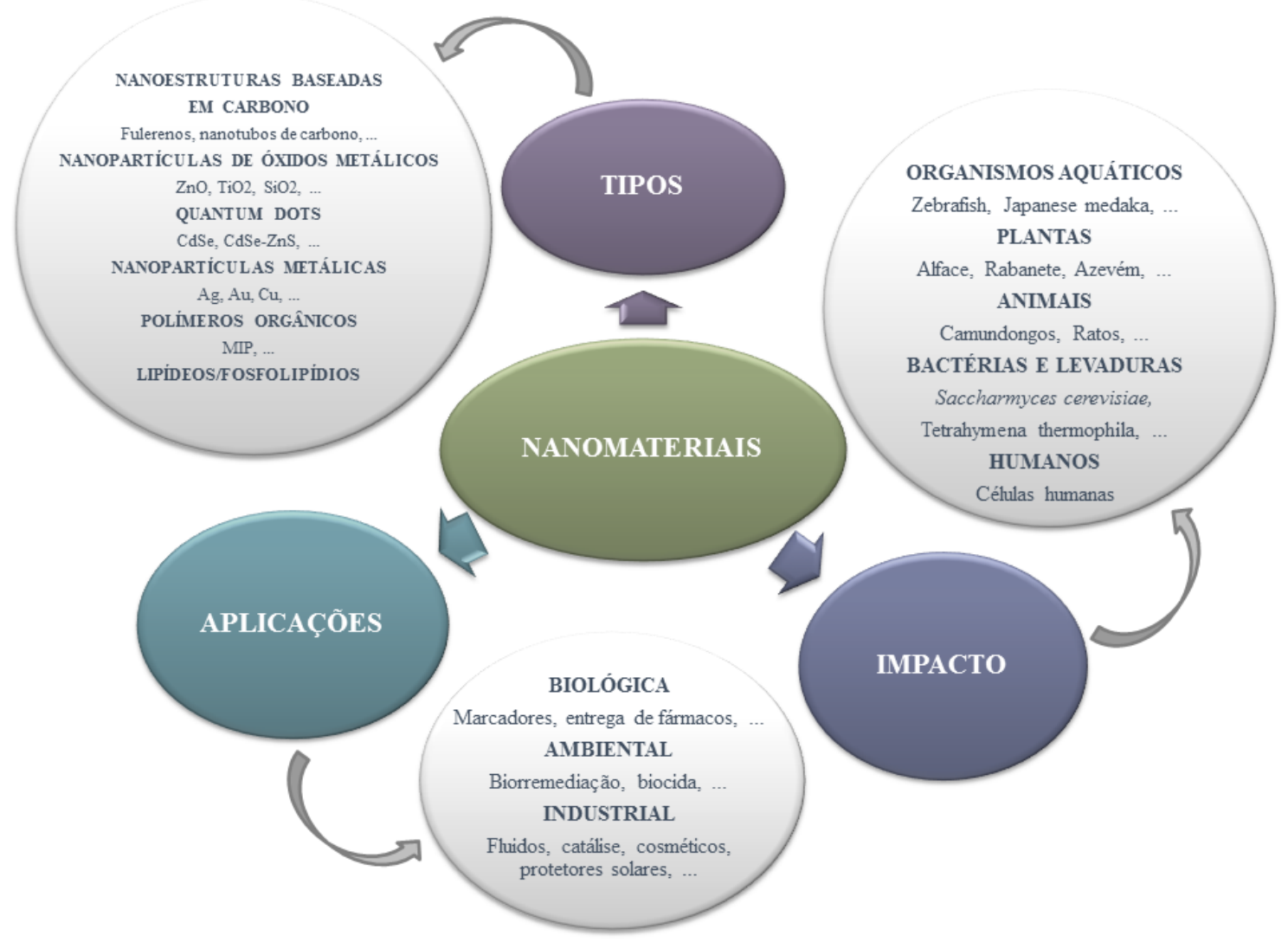

Figura 1. Classificação, aplicações e impacto para nanomateriais. Modificado de LÓPEZSERRANO et al. (2014). 


\subsection{CARACTERÍSTICAS FÍSICO-QUÍMICAS}

Devido ao uso dos nanomateriais em diferentes áreas e aplicações, tornou-se necessário desenvolver padrões robustos para a sua caracterização, a fim de conhecer as possíveis interações fisiológicas, biodistribuição, transporte e endocitose dos nanomateriais através dos diferentes tecidos. Embora atualmente não existam metodologias padronizadas ou protocolos regulatórios, alguns laboratórios como o NLC ("Nanotechnology Characterization Lab") fornecem informações sobre métodos de caracterização físico-química $\mathrm{e}$ de toxicidade in vitro $\mathrm{e}$ in vivo (http://nlc.cancer.gov/working_assay_cascade.asp).

As propriedades físicas e químicas incluem uma vasta gama de características das partículas, tais como a composição elementar, densidade, estrutura cristalina, reatividade química, solubilidade, e as constantes físicas, tais como a condutividade, o ponto de fusão, dureza, e propriedades ópticas (LIN et al., 2014). Para algumas nanopartículas, estas propriedades são as mesmas ou semelhantes às propriedades do material em escala convencional. No entanto, uma das principais razões pelas quais as nanopartículas são de interesse é a capacidade de mudar estas propriedades à medida que diminui o tamanho da partícula, geralmente abaixo de $100 \mathrm{~nm}$, e especialmente abaixo de $10 \mathrm{~nm}$ (POWERS et al., 2006).

Considerando o parágrafo anterior, a apropriada caracterização física e química dos nanomateriais é essencial na determinação das suas propriedades intrínsecas, tais como a pureza, tamanho, solubilidade, carga e cristalinidade, para elucidar a homogeneidade, estabilidade, reatividade, durabilidade biológica, potencial de aplicação destas em diferentes ambientes, assim como, correlacionar tais propriedades com sua atividade biológica e possível promoção de toxicidade (OBERDÖRSTER et al., 2005; CONG et al., 2011). A utilização de diferentes métodos e técnicas de caracterização permite realizar uma abordagem confiável visando garantir a qualidade, segurança e desenvolvimento racional de novos nanomateriais. Entre as técnicas mais utilizadas estão a microscopia eletrônica, espalhamento de luz, espectroscopia óptica, dicroísmo circular, ressonância magnética, espectrometria de massas, espectroscopia e espalhamento de raios X, cromatografia e eletroforese, entre outros (SAPSFORD et al., 2011; LIN et al., 2014). Nos parágrafos seguintes resumiremos a importância de cada 
uma destas técnicas nos processos de caracterização dos nanomateriais.

\subsubsection{Tamanho e formato}

O tamanho é um fator importante a ser considerado quando se trabalha com nanomateriais. Dependendo do tipo de nanomaterial, o tamanho pode ser equivalente ao diâmetro de uma partícula com formato esférico, fornecendo-lhe características especificas como, por exemplo, sua biodistribuição nos organismos. (LIN et al., 2014). 0 tamanho também é uma das características que influencia no tempo de circulação dos nanomateriais na corrente sanguínea, penetração através de diferentes barreiras biológicas; distribuição nos tecidos e também indução de respostas celulares (JIANG et al., 2008).

Outro exemplo da importância do tamanho das nanopartículas em sistemas biológicos vem do fato que a captação celular pode acontecer quando as células são expostas às partículas coloidais com um tamanho que varia de nanômetros a mícrometros, pois as células possuem funções definidas para regular a captação e transporte de componentes biológicos neste intervalo (MAO et al., 2013). Assim, é importante considerar os tamanhos dos componentes biológicos envolvidos no processo de incorporação como, por exemplo, a espessura da maioria das bicamadas lipídicas das membranas celulares, as quais apresentam uma espessura aproximada de 4-10 nm; e o diâmetro do complexo do poro nuclear em vertebrados, que se encontra ao redor dos 80-120 nm. Estas estruturas biológicas com restrição de tamanho natural podem executar funções de barreira na incorporação de partículas, determinando os caminhos e os mecanismos de absorção de nanopartículas com diferentes tamanhos (ZHU et al., 2013).

A Figura 2 ilustra os tamanhos mais cruciais envolvidos em diferentes formas de captação e transporte celular. Na literatura se descreve que a captação de micropartículas maiores que $0,5 \mu \mathrm{m}$ é geralmente através de fagocitose e para as partículas menores que 0,2 $\mu \mathrm{m}$ é geralmente através pinocitose (CHITHRANI et al., 2006; YUAN et al., 2010). A quantidade de receptores envolvidos na captação celular também é em grande parte dependente do tamanho de partícula, desde que o processo de captação celular é fortemente dependente do tempo que tarda a invaginação das 
nanopartículas, que se baseia na velocidade de difusão dos receptores na superfície da membrana celular (JIANG et al., 2008). As partículas coloidais extremamente pequenas ou grandes podem conduzir a uma absorção pouco eficiente ou ineficiente (MAO et al., 2013).

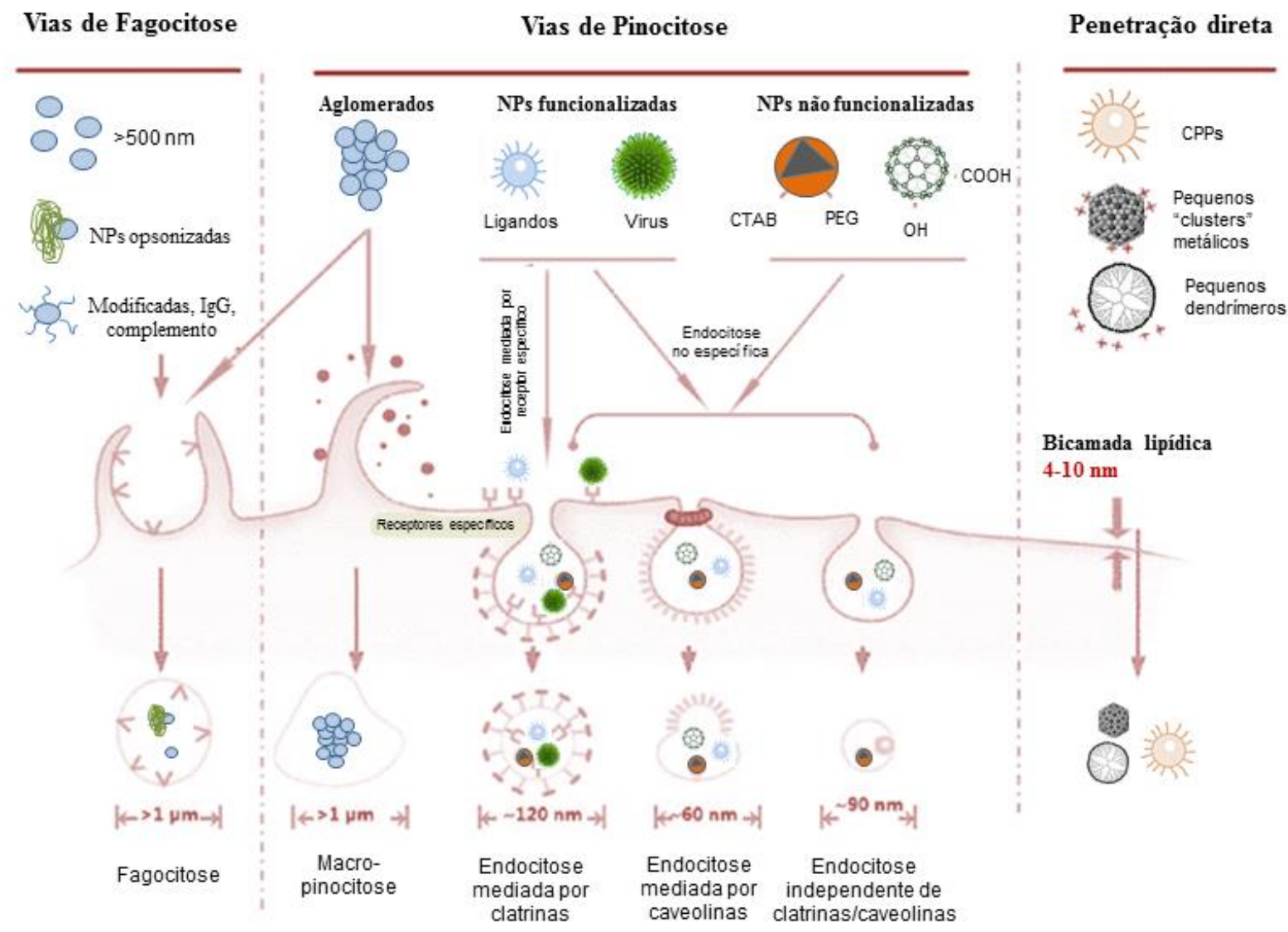

Figura 2. A incorporação celular de partículas é dominada pelos tamanhos biológicos e pelos porteiros nas células dos mamíferos. A espessura da bicamada lipídica da membrana encontrase ao redor dos 4-10 nm. Fagócitos podem captar grandes partículas (ou agregados de partículas), partículas opsonizadas, ou partículas modificadas com ligantes via fagocitose. A incorporação de partículas em células não fagocitárias de mamífero ocorre, principalmente, através de pinocitose ou penetração direta. Com diferentes modificações da superfície, as partículas podem ser incorporadas através de endocitose específica (mediada por receptores) ou endocitose não específica. A heterogeneidade das superfícies das partículas e a dispersão sempre requerem múltiplas vias de captação para serem envolvidos. Modificado de Zhu e colaboradores (2013).

Em geral, a toxicidade das partículas está diretamente relacionada com sua captação pelas células, desde que a velocidade e a quantidade de partículas captadas aumentam ao diminuir o tamanho da partícula, em células não fagocitárias (KETTLER et al., 2014a). Vale ressaltar que uma característica física importante dos nanomateriais, 
associadas ao tamanho, é a área superficial, que implica em maior reatividade da sua superfície e solubilidade (Figura 3). Tais características dos nanomateriais podem fazer com que a atividade biológica seja maior em comparação com partículas maiores, constituindo-se em um ponto crítico na determinação da segurança (MISRA et al., 2012). Obviamente, o formato e a composição química são fatores também importantes que podem influenciar a toxicidade de nanomateriais (LIN et al., 2014).

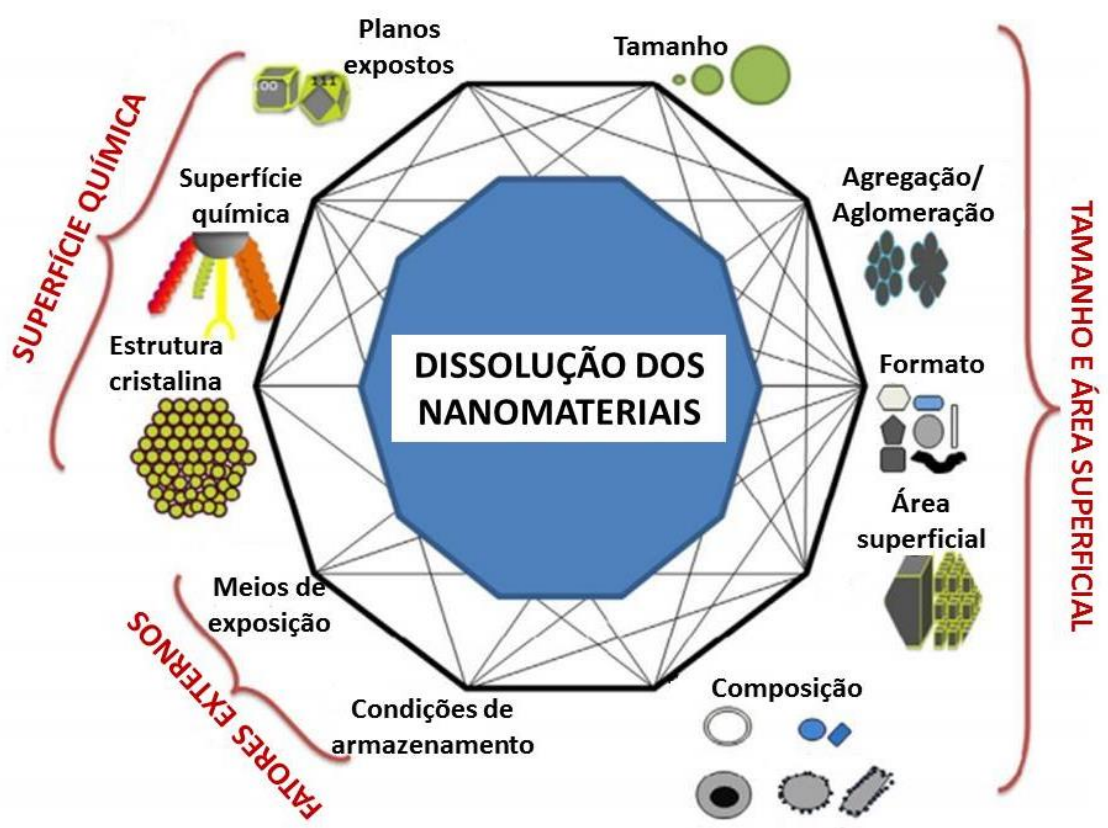

Figura 3. Caraterísticas dos nanomateriais e fatores que podem afetar a sua dissolução. Modificado de MISRA et al. (2012).

Tamanho e consequentemente sua área superficial também apresentam correlação direta com a dissolução dos nanomateriais, uma propriedade importante que influencia seu modo de ação (por exemplo, propriedades antimicrobianas, toxicidade, aplicações medicinais e impacto ambiental). 0 parâmetro físico-químico que controla este processo é conhecido como solubilidade, que junto com a concentração e superfície das partículas, age como uma força motriz na dissolução da partícula. O potencial de dissolução dos nanomateriais pode influenciar a sua persistência e/ou transformação no meio ambiente e atuar como um controle importante na sua resposta biológica, considerando que a dissolução pode levar a liberação de íons altamente tóxicos (MISRA et al., 2012).

A correlação entre dissolução e as propriedades físico-químicas dos nanomateriais é na maioria das vezes difícil de estabelecer. Isto implica a utilização e adaptação de 
diferentes técnicas existentes que permitam realizar uma caracterização eficaz antes de realizar testes de toxicidade (CONG et al., 2011). Assim, a caracterização de nanomateriais é necessária para assegurar que os testes de toxicidade sejam mais confiáveis e reprodutíveis. Sem tal caracterização, os experimentos de nanotoxicidade terão valor limitado devido à ampla variabilidade das nanopartículas, a maioria das vezes desconhecida em diferentes condições experimentais (ROGERS et al., 2007; CONG et al., 2011).

O formato das nanopartículas é uma propriedade importante que pode influenciar a bioacumulação e, portanto, a toxicidade (DAI et al., 2015). Por exemplo, as nanopartículas esféricas de $\mathrm{TiO}_{2}(11 \mathrm{~nm})$ causam 5 vezes maior mortalidade do que as nanopartículas de $\mathrm{TiO}_{2}$ de formato alongado (44 nm x $1500 \mathrm{~nm}$ ) em bactérias Escherichia coli (SIMON-DECKERS et al., 2009). Pal e colaboradores (2015) encontraram que as AgNP de formato triangular inibiram mais eficazmente o crescimento das bactérias (E. coli) do que as nanoesferas ou nanobastões de prata. Zhao e colaboradores (2013) observaram que a hidroxiapatita com formato de agulha retardou em maior medida a eclosão dos embriões de Danio rerio do que a hidroxiapatita com formato de bastonete. Wang e colaboradores (2016) observaram que a toxicidade das nanopartículas de ouro, em embriões de zebrafish, é dependente do formato, encontrando que as nanoesferas de ouro apresentaram maior toxicidade quando comparadas com nanobastões e nanopoliedros. Os estudos mencionados anteriormente são exemplos de como o formato dos nanomateriais tem um importante impacto sobre a toxicidade em diferentes organismos, considerando que as vias e os tipos de incorporação celular dependem também deste parâmetro (MITRAGOTRI, 2009; KETTLER et al., 2014).

Na Figura 4 está representada, a modo geral, a incorporação por endocitose de nanoparticulas com diferentes formatos. Para as partículas concebidas como esféricas, bastões e discos, a endocitose pode ser dividida em duas fases: a invaginação da membrana e as partículas embrulhadas (LI et al., 2012). Durante a primeira fase, as nanopartículas são orientadas para a membrana de tal forma que a interação ligantereceptor torna-se maior, isto devido à maximização da área de contato, estimulando a invaginação da membrana. A cinética da segunda etapa, o embrulhamento da 
nanopartícula, é regulado pela maior curvatura que conduz à reorientação das nanopartículas de formato anisotrópico (por exemplo, bastões e discos). Um dos requisitos para que a interiorização de nanopartículas seja bem sucedida é a liberação de energia para estabelecer a ligação ligante-receptor, que deve superar à energia necessária para a flexão da membrana durante o embrulho (KETTLER et al., 2014a; LI et al., 2012).

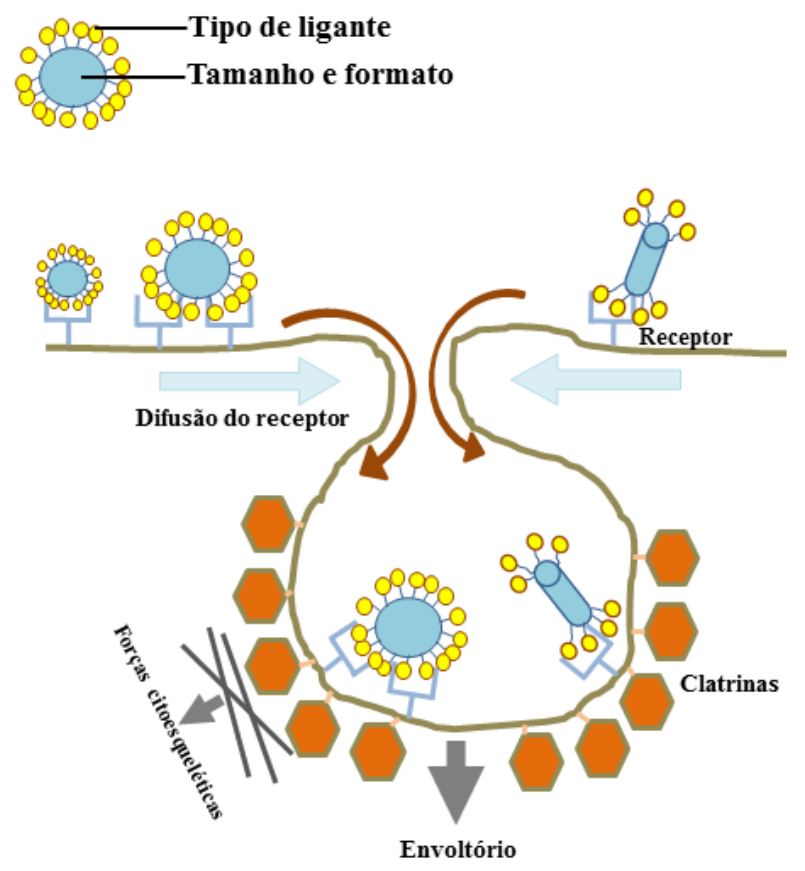

Figura 4. Mecanismos de incorporação de nanopartículas com diferentes formatos. Da esquerda para a direita: absorção de uma partícula grande por fagocitose, interiorização do líquido junto com as partículas por macropinocitose, ligação específica de ligantes a receptores da superfície celular e subsequentemente, endocitose mediada por receptores, e a difusão de nanopartículas através da bicamada lipídica da membrana celular, incluindo proteínas transportadoras/canal. Tomado e modificado de Qiu e colaboradores (2010).

Existe uma ampla variedade de métodos para determinar a distribuição do tamanho e forma das partículas (Tabela 1), incluindo microscopia eletrônica, espalhamento dinâmico de luz, medidas de área superficial, entre outras. Diretrizes de organizações tais como "International Standards Organization-ISO", "American Society for Testing and Materials-ASTM", "United States Pharmacopeia-USP", estabelecem diferentes parâmetros para a realização destas medidas (POWERS et al., 2006). 
A microscopia é uma das técnicas mais importantes que permite a visualização das nanopartículas, fornecendo informação exclusiva sobre o tamanho, formato e morfologia (POWERS et al., 2006). Entre as técnicas baseadas em microscopia, de maior utilização, podemos citar a microscopia eletrônica de transmissão e varredura (CÁCERES-VÉLEZ et al., 2016; CAO et al., 2016); e microscopia de força atômica (TIEDE et al., 2009; DENG et al., 2016). Outra técnica que permite determinar o tamanho dos nanomateriais é a difração de raios X (DRX) (MARIEN et al., 2016).

A luz pode produzir uma serie de informações valiosas sobre as propriedades de macromoléculas, incluindo a massa molecular, dimensões e coeficientes de difusão, bem como das propriedades de associação/dissociação e a dinâmica interna das amostras (SAPSFORD et al., 2011). A determinação da distribuição do tamanho das partículas é frequentemente realizada por meio de uma técnica conhecida como espalhamento dinâmico de luz ("Dynamic Ligth Scattering-DLS"). Embora esta técnica permita determinar (in situ) o tamanho e a concentração de partículas na amostra de uma maneira rápida (SAPSFORD et al., 2011), apresenta limitações relacionadas às características do meio e à polidispersidade das amostras (TIEDE et al., 2009). Outra técnica atualmente utilizada é o "Nanoparticle tracking analysis-NTA", onde se realiza o rastreamento das partículas através do espalhamento de luz a partir de nanopartículas se movendo sob movimento browniano (SAPSFORD et al., 2011). 
Tabela 1. Técnicas de caracterização físico-química aplicáveis a sistemas nanoparticulados. Tomado e modificado de Lin et al. (2014) e Powers et al. (2006).

\begin{tabular}{|c|c|c|c|}
\hline TÉCNICA & $\begin{array}{l}\text { FAIXA DE } \\
\text { TAMANHO } \\
\text { NOMINAL }\end{array}$ & VANTAGENS & DESVANTAGENS \\
\hline $\begin{array}{c}\text { Espalhamento } \\
\text { dinâmico de luz } \\
\text { ab,e }\end{array}$ & $4 \mathrm{~nm}-6 \mu \mathrm{m}$ & $\begin{array}{c}\text { Pode ser também } \\
\text { utilizado para } \\
\text { determinar o potencial- } \\
\zeta \text {, medida de partículas } \\
\text { em qualquer solvente }\end{array}$ & $\begin{array}{l}\text { Menos confiável para } \\
\text { distribuição ampla de } \\
\text { tamanho, Assume } \\
\text { partículas esféricas }\end{array}$ \\
\hline $\begin{array}{c}\text { Difração estática de } \\
\text { luz }^{b}\end{array}$ & $40 \mathrm{~nm}-3 \mathrm{~mm}$ & $\begin{array}{l}\text { Ampla faixa dinâmica- } \\
\text { medidas para material } \\
\text { seco ou húmido }\end{array}$ & $\begin{array}{l}\text { Assume partículas } \\
\text { esféricas, o efeito do } \\
\text { formato é desconhecido }\end{array}$ \\
\hline $\begin{array}{l}\text { Análise de } \\
\text { rastreamento de } \\
\text { nanopartículas }^{h}\end{array}$ & $30-1000 \mathrm{~nm}$ & $\begin{array}{c}\text { Moni/polidispersas, } \\
\text { medidas individuais de } \\
\text { partículas, concentração } \\
\text { aproximada, }\end{array}$ & $\begin{array}{l}\text { Baixa reprodutibilidade, } \\
\text { artefatos pelo preparo da } \\
\text { amostra }\end{array}$ \\
\hline $\begin{array}{c}\text { Varredura/ análise } \\
\text { de mobilidade } \\
\text { diferencial }^{b}\end{array}$ & $2 \mathrm{~nm}-2 \mu \mathrm{m}$ & $\begin{array}{c}\text { Bom para distribuições } \\
\text { de tamanho }\end{array}$ & $\begin{array}{c}\text { Técnica de baixa pressão } \\
\text { à seco, amostras } \\
\text { pequenas }\end{array}$ \\
\hline $\begin{array}{l}\text { Espectroscopia UV- } \\
\text { visível }^{i}\end{array}$ & $\begin{array}{c}\leq 0,5 \mathrm{de} \\
\text { absorbância } \\
\left(\sim 10.000 \mathrm{dm}^{3}\right. \\
\left.\mathrm{mol}^{-1} \mathrm{~cm}^{-1}\right)\end{array}$ & $\begin{array}{l}\text { Tamanho, concentração, } \\
\text { agregação, estrutura } \\
\text { conformacional de } \\
\text { moléculas }\end{array}$ & $\begin{array}{l}\text { Artefatos pelo preparo } \\
\text { da amostra, maior } \\
\text { sensibilidade compostos } \\
\text { orgânicos }\end{array}$ \\
\hline $\begin{array}{l}\text { Microscopia } \\
\text { eletrônica }{ }^{a, c, f}\end{array}$ & $\geq 0,3 \mathrm{~nm}$ & $\begin{array}{c}\text { Boa resolução e imagem, } \\
\text { análise de partículas } \\
\text { individuais }\end{array}$ & $\begin{array}{l}\text { Artefatos pelo preparo } \\
\text { da amostra e vácuo }\end{array}$ \\
\hline $\begin{array}{l}\text { Microscopia de força } \\
\text { atômica }{ }^{b, g}\end{array}$ & $\geq 5 \mathrm{~nm}$ & $\begin{array}{l}\text { Boa resolução e imagens } \\
\text { 3-D, análise de } \\
\text { partículas individuais }\end{array}$ & $\begin{array}{l}\text { Mapeamento de } \\
\text { pequenas áreas, artefatos } \\
\text { pelo contato com o } \\
\text { "cantilever" }\end{array}$ \\
\hline $\begin{array}{l}\text { Área específica da } \\
\text { superfície }^{d}\end{array}$ & $\geq 5 \mathrm{~nm}$ & $\begin{array}{l}\text { Simples e aplicável à } \\
\text { maioria dos sistemas }\end{array}$ & $\begin{array}{c}\text { Assume que as partículas } \\
\text { são monodispersas e não } \\
\text { porosas }\end{array}$ \\
\hline
\end{tabular}

aBootz et al. (2004); bjillavenkatesa and Kelly (2002); cSjostrom et al. (1995); dLowell et al.

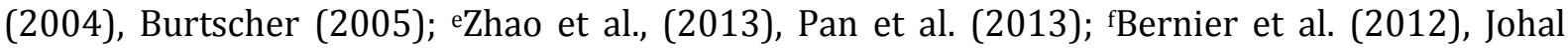
(2011); gSapsford et al. (2011b); hFilipe et al., (2010); Sapsford et al. (2011b); 'Hofmann (2010).

\subsubsection{Superfície e composição química}

As características físico-químicas são em função da composição atômica e molecular da superfície e da estrutura física das superfícies, o que conduz a diferentes respostas como resultado das interações entre o nanomaterial e o meio em que se encontram (POWERS et al., 2006). Entre as diferentes propriedades da superfície 
consideradas como parâmetros importantes estão a composição, área superficial, carga e funcionalização da superfície.

Existem estudos onde se abordam várias questões sobre como a composição química determina a toxicidade dos nanomateriais (BUZEA et al., 2007), pois esta pode influenciar o seu transporte, entrega e biodistribuição nos organismos. As diferentes aplicações dadas a algumas nanopartículas podem fazer com que surja a necessidade de combinar dois ou mais tipos de nanomateriais para formar um mais complexo (PATRI et al., 2006). Como consequência disso, a maioria das vezes torna-se difícil medir diretamente a composição atômica das superfícies, já que muitos destes sistemas estão sujeitos aos contaminantes que podem não ser detectados por análise química geral (POWERS et al., 2006).

A difração de raios X (DRX) é uma técnica que permite conhecer, além da estrutura cristalina, a composição química e o estado dos nanomateriais (SIDDIQUI et al., 2016). Outra técnica que está sendo amplamente utilizada para caracterização química da superfície dos nanomateriais é a Espectroscopia Eletrônica para Análise Química ("ESCA"), ou a Espectroscopia Fotoeletrônica de raios X (XPS) (GREGUREC et al., 2014; PSHYK et al., 2016), que pode ser utilizada para diferentes tipos de amostras, fornecendo informações importantes que permitem correlacionar as propriedades da superfície dos nanomateriais com os seus efeitos biológicos (RATNER, 1996; FLAK et al., 2015; ESGUERRA-ARCE et al., 2016). Desta maneira, a análise mais básica por XPS de uma superfície pode fornecer informações qualitativa e quantitativa de todos os elementos presentes, exceto do hidrogênio e o hélio. As aplicações mais sofisticadas desta técnica permitem conhecer informação detalhada da química, organização e morfologia da superfície (POLITAKOS et al., 2016).

Por ser uma técnica não tão difundida e conhecida, descreveremos, brevemente, os princípios básicos da análise por XPS.

Os componentes principais de um XPS são o sistema de vácuo, a fonte de raios $\mathrm{X}, \mathrm{o}$ analisador de energia e um sistema de dados (Figura 5). Na câmara principal de vácuo, onde a amostra é analisada, é importante que o percurso dos fotoelétrons, desde a amostra até o detector, não colidam com outras partículas da fase gasosa. As fontes de 
raios X são aquelas que usam ânodos de alumínio ou magnésio, sílica, zircônio, prata, titânio e crômio; sendo as mais comumente utilizadas a de magnésio (radiação $\mathrm{K}_{\alpha}$ : $h v=1253,6 \mathrm{eV}$ ) e alumínio (radiação $\mathrm{K}_{\alpha}: h v=1486,6 \mathrm{eV}$ ) (WAGNER et al., 1979).

A radiação X é monocromatizada com um cristal de quartzo antes de chegar à amostra, o qual permite aproveitar uma faixa de energia onde a intensidade da radiação $\mathrm{X}$ é máxima, evitando os picos satélites de florescência de raios $\mathrm{X}$, e que os elétrons de alta energia degradem a amostra. A utilização de um monocromador provoca a diminuição da intensidade dos raios X que interagem com a amostra. Essa diminuição no fluxo energético é compensada no sistema analisador, constituído por lentes que captam a radiação, um analisador de energia e um sistema detector multicanal (WAGNER et al., 1979).

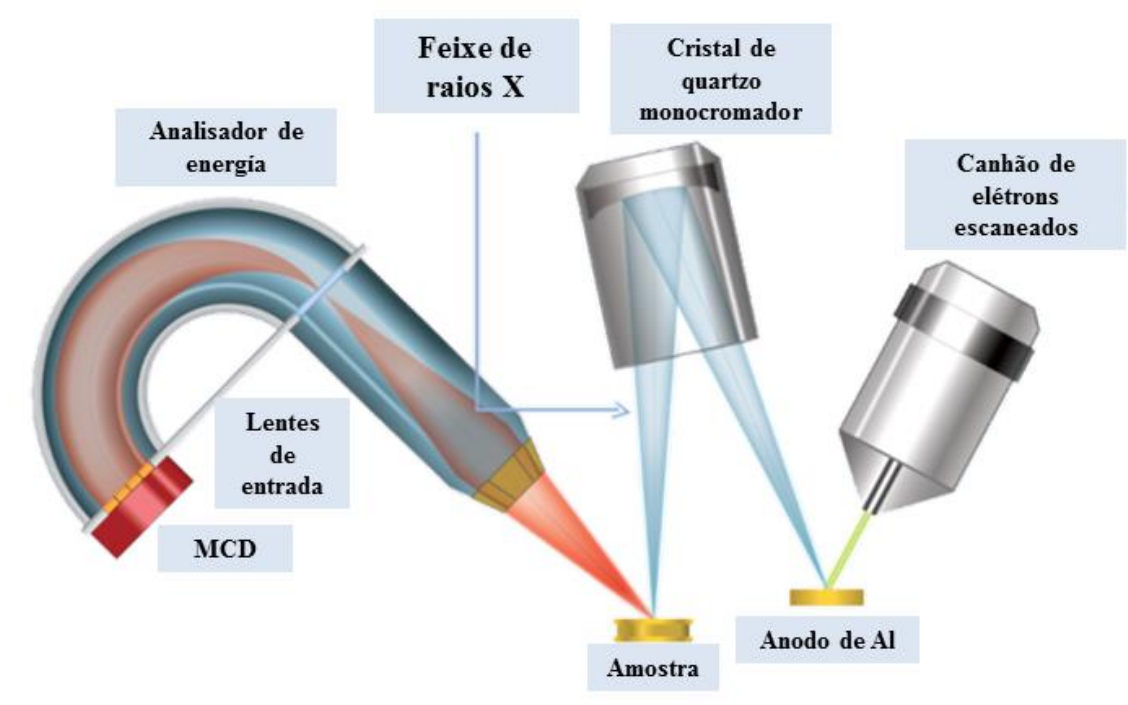

Figura 5. Componentes básicos de um sistema de XPS monocromático. Detector multicanal (MCD).

0 principio físico da espectroscopia de fotoelétrons é baseado na energia de um fóton, a qual é dada pela relação de Einstein:

$$
E=h v
$$


Onde,

$h$ : Constante de Planck $\left(6,62 \times 10^{-34} \mathrm{Js}\right)$

v: Frequência $(\mathrm{Hz})$ da radiação

O fóton é absorvido por um átomo de uma molécula, conduzindo a ionização e a emissão de um elétron do núcleo (camada interna). A distribuição da energia cinética dos fotoelétrons emitidos (isto é, o numero de fotoelétrons emitidos como uma função da sua energia cinética) pode ser medida utilizando um analisador de energia dos elétrons para medir a energia dos fotoelétrons emitidos. Desta maneira, a identidade elementar, estado químico e a quantidade de um elemento detectado podem ser determinadas a partir da energia de ligação e a intensidade de um pico fotoeletrônico (WAGNER et al., 1979).

O processo de fotoionização pode ser considerado de varias formas, uma delas é analisando o processo geral, assim:

$$
\mathrm{A}+h v \rightarrow \mathrm{A}^{+}+\mathrm{e}^{-}
$$

A conservação da energia, em seguida, exige que;

$$
\mathrm{E}(\mathrm{A})+h v=\mathrm{E}\left(\mathrm{A}^{+}\right)+\mathrm{E}\left(\mathrm{e}^{-}\right)
$$

Como a energia do elétron está presente apenas como energia cinética (EC), isto pode ser rearranjado para dar a seguinte expressão para a EC do fotoelétron;

$$
\mathrm{EC}=h v-\left(\mathrm{E}\left(\mathrm{A}^{+}\right)-\mathrm{E}(\mathrm{A})\right)
$$

O termo final entre parênteses representa a diferença de energia entre os átomos ionizados e neutros, e é geralmente nomeado como energia de ligação (EL) do elétron. Isto leva à seguinte equação;

$$
\mathrm{EC}=h v-\mathrm{EL}-\phi_{\mathrm{sp}}
$$


Onde,

$h v$ : energia do fóton

EL: energia de ligação do orbital atômico da onde é o elétron

$\phi_{\text {sp: }}$ função de trabalho do espectrômetro

Na figura abaixo se mostra este efeito:
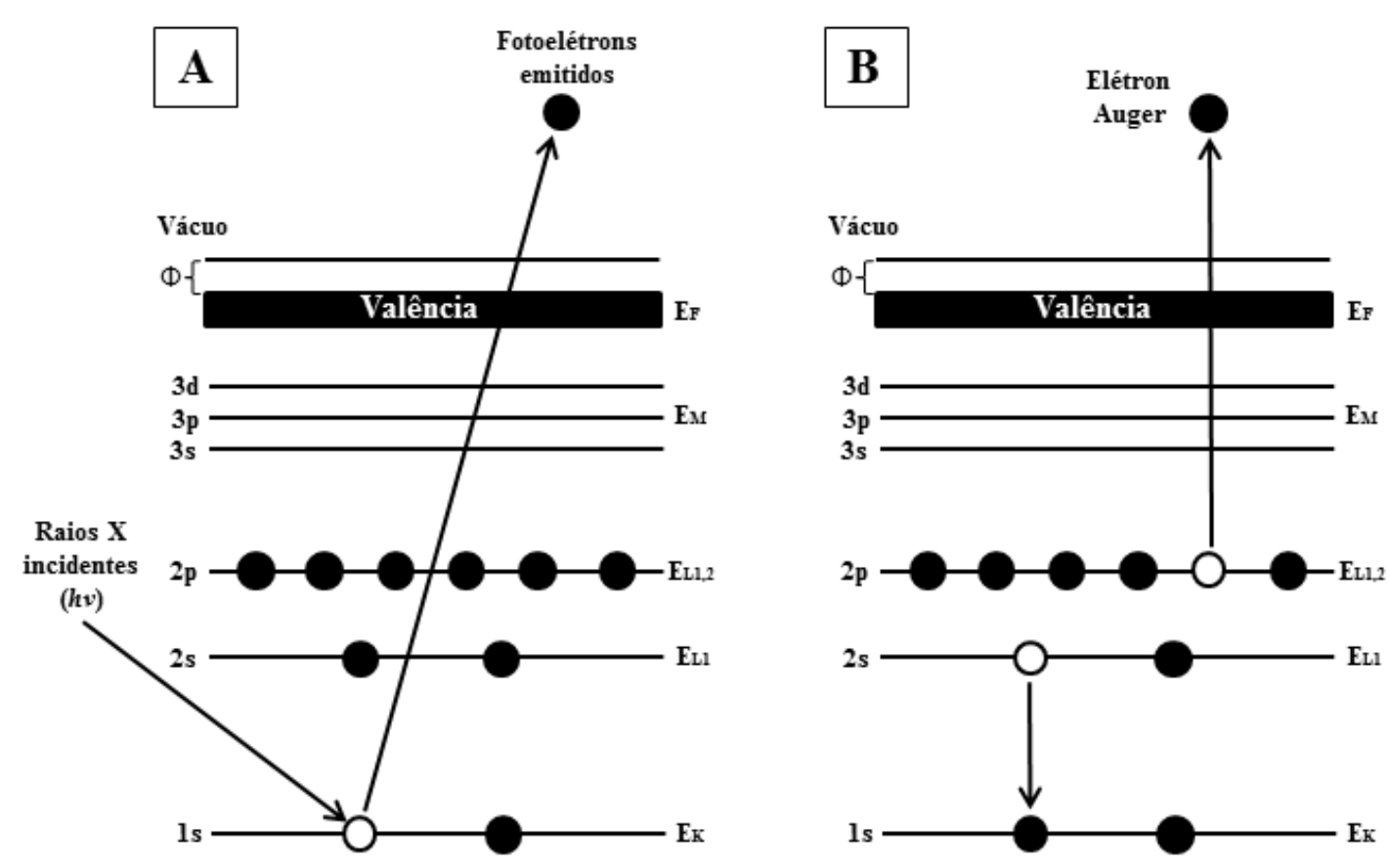

Figura 6. Diagrama de um processo fotoelétrico (A), onde um fóton transfere a sua energia a um elétron que é posteriormente emitido. 0 excesso de energia no átomo é compensado com a ocupação da vacância de baixa energia por um elétron de um nível de energia maior. Outra forma de libera esse excesso de energia é realizada com a emissão de um elétron Auger (B) ou emitindo um fóton de raios X. Tomado e modificado de (WAGNER et al., 1979).

A fotoionização conduz a emissão de fotoelétrons e elétrons Auger que são emitidos devido ao relaxamento dos íons energéticos que sobram após a fotoemissão (Figura 7B). Esta emissão do elétron Auger, ocorre aproximadamente em 10-14 segundos após o evento fotoelétrico. A emissão de um fóton de raio X fluorescente é um processo insignificante na escala de energia, ocorrendo pelo menos de $1 \%$ em cada vez (WAGNER et al., 1979). 
No processo Auger, um elétron cai dentro do orbital vacante interno, e um segundo elétron é emitido, carregando o excesso de energia. Os elétrons ejetados são denominados elétrons Auger, em homenagem ao seu descobridor, o professor Pierre Auger, em 1927. 0 elétron Auger possui energia cinética igual à diferença entre a energia do íon inicial e a dupla carga do íon final, e é independente do modo de ionização inicial. É certo que as energias dos elétrons emitidos não podem exceder a energia dos fótons ionizantes. A energia cinética dos elétrons Auger está compreendida na faixa entre 10 e $3000 \mathrm{eV}$, e o caminho livre médio destes elétrons nos sólidos fica em torno de 0,3 e $3 \mathrm{~nm}$. Por isto, apenas os elétrons originados nas camadas atômicas mais superficiais chegam a ser emitidos. Em síntese, a espectroscopia Auger, uma das mais difundidas técnicas de estudo de superfícies, consiste na análise da energia cinética de elétrons emitidos pela amostra, originários das camadas internas dos átomos (WAGNER et al., 1979).

Outro método comumente utilizado para a análise físico-químico das superfícies é a microscopia eletrônica de varredura, que além de fornecer informação sobre a área superficial, agregação, dispersão e estrutura, permitem conhecer a composição elementar das amostras quando combinado à espectroscopia de raios $\mathrm{X}$ por dispersão de energia (GUSAIN et al., 2016). 0 detector de energia dispersiva de raios X (EDX ou "EDSEnergy Dispersive X-Ray Spectroscopy") é capaz de detectar os fótons de raios-X emitidos pela amostra (Figura 7); estes por sua vez são analisados e classificados em função da sua energia e intensidade. Na análise de EDS é usado um material semicondutor para detectar os raios X em uma contagem eletrônica que resulta em um espectro que representa a análise química da amostra (NYLESE, 2015). 


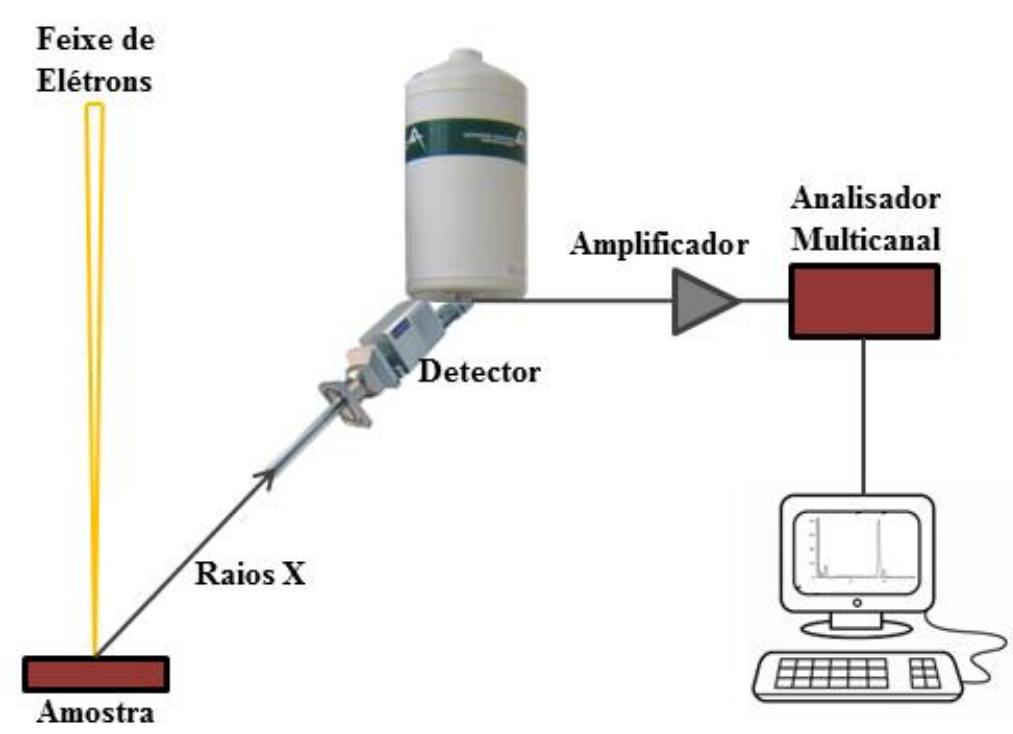

Figura 7. Componentes principais de um sistema de espectroscopia por dispersão de energia. Tomado e modificado de Dedavid e colaboradores (2007).

Como colocado anteriormente, outro parâmetro a ser avaliado, por ter influência direta nos possíveis efeitos tóxicos dos nanomateriais, é a área superficial. A área superficial está em função do número, formato e diâmetro das partículas, de tal modo que quando as partículas se tornam menores, a área superficial específica $\left(\mathrm{m}^{2} / \mathrm{g}\right)$ aumenta rapidamente, podendo ter uma área superficial na ordem de centenas de metros quadrados por grama (POWERS et al., 2006). Desta maneira, a taxa de dissolução, solubilidade, estabilidade, incorporação e geração de espécies reativas de oxigênio, entre outras, podem aumentar drasticamente quando a área superficial é maior.

A área superficial efetiva e a porosidade das nanoparticulas em ambientes biológicos podem mudar como resultado da adsorção de biomoléculas ou pela aglomeração. A medida da área superficial e/ou a porosidade das partículas no meio biológico é limitada a técnicas conduzidas sobre condições fisiológicas simuladas. A técnica mais utilizada para fazer a estimativa da área da superficial é a microscopia eletrônica de varredura (DUFFIN et al., 2001; MAYNARD, 2003).

A carga superficial também é uma característica importante a ser considerada, pois esta modula também a ligação entre os receptores das células, bem como a sua penetração nas barreiras biológicas (LIN et al., 2014). Estudos recentes tem mostrado 
que a incorporação de nanopartículas é favorecida para as carregadas negativamente, em comparação com aquelas carregadas positivamente ou neutras (LIU et al., 2011; LUYTS et al., 2013). As partículas carregadas positivamente podem apresentar um potencial tóxico maior do que as com carga negativa, podendo induzir alterações mitocondriais, produção elevada de espécies reativas de oxigênio (BHATTACHARJEE et al., 2010) e danos no DNA (LIU et al., 2011). Em contraste, no estudo realizado por Park e colaboradores (2013) foi observado que a as nanopartículas de sílica (20nm de diâmetro, com diferentes valores de carga negativa) com maior carga negativa causaram efeitos citotóxicos e geração de espécies reativas de oxigênio em maior medida do que aquelas com carga negativa menor. Contudo, a relação entre carga superficial/potencial$\zeta$ e toxicidade não pode ser totalmente generalizada (LUYTS et al., 2013). Além disso, é conhecido que cargas elevadas evitam a aglomeração e partículas com baixo potencial- $\zeta$ tendem a se agregar, diminuindo a taxa de incorporação nas células (HANAOR et al., 2012; ZHAO E WANG, 2012). A carga superficial é avaliada principalmente utilizando-se

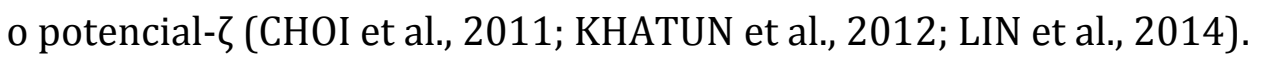

Outra propriedade importante que afeta as aplicações biológicas dos nanomateriais é a sua funcionalização superficial, pois pode determinar a via de captação celular, tráfego intracelular e citotoxicidade (HAVRDOVA et al., 2016). Assim, para as diferentes aplicações, a funcionalização das nanopartículas deve ser cuidadosamente projetada para produzir o efeito desejado (PELAZ et al., 2015). A funcionalização da superfície pode ser feita com diferentes agentes de acoplamento, dando a possibilidade de se ligarem moléculas diferentes que podem alterar as propriedades da sua superfície, modificando sua biocompatibilidade e destino no organismo.

As nanopartículas quando em contato com os fluidos biológicos e/ou o conteúdo celular são rapidamente cobertas por macromoléculas biológicas, tais como proteínas, lípidos e hidratos de carbono, as quais podem alteram as suas propriedades biológicas (GARNETT E KALLINTERI, 2006). Quando se objetiva aumentar o tempo de circulação, nanopartículas são revestidas com materiais poliméricos, tais como dextrano, quitosano, poli (álcool vinílico), poli ( $\varepsilon$-caprolactona) ou poli (etileno glicol) (PEG) (BARRERA et al., 2009). Estes polímeros hidrofílicos ligados à superfície das nanopartículas diminuem o 
processo de opsonização que resulta em uma meia-vida mais longa das nanopartículas revestidas na corrente sanguínea. Além disso, a modificação da superfície das nanopartículas com polímeros melhora a sua estabilização em água e reduz a aglomeração de partículas (CHO et al., 2008). Deste modo, a biodistribuição, movimento de materiais através de tecidos, fagocitose, opsonização e endocitose de materiais nanométricos podem ser modificados dependendo da funcionalização da superfície das nanopartículas (GARNETT E KALLINTERI, 2006).

Algumas das técnicas mais utilizadas para caracterizar as superfícies funcionalizadas dos nanomateriais são a espectroscopia de fotoelétrons excitados por raios X (XPS), a microscopia eletrônica de transmissão de alta resolução (HR-MET) e a espectroscopia de reflexão total atenuada no infravermelho com transformada de fourier (ATR-FTIR). Na seguinte tabela (Tabela 2) estão listados outros métodos comumente utilizados para a análise físico-química das superfícies dos materiais nanoestruturados. 
Tabela 2. Técnicas aplicáveis para análise de superfícies em sistemas nanoparticulados. Tomado e modificado de Lin et al. (2014) e Powers et al. (2006).

\section{PROFUNDIDAD}

TÉCNICA

DE

APLICAÇÕES

LIMITAÇõES

PENETRAÇÃO*

\begin{tabular}{|c|c|c|c|}
\hline $\begin{array}{l}\text { Espectroscopia de } \\
\text { elétrons Auger }{ }^{a}\end{array}$ & $1-5 \mathrm{~nm}$ & Composição da superfície & $\begin{array}{l}\text { Não podem ser utilizados } \\
\text { isolantes devido à carga } \\
\text { significativa, danos na } \\
\text { superfície, AV-UAV }\end{array}$ \\
\hline $\begin{array}{l}\text { Espectroscopia por } \\
\text { perda de energia de } \\
\text { elétrons }^{b}\end{array}$ & Poucos nm & $\begin{array}{c}\text { Composição da superfície e } \\
\text { mapeamento elementar }\end{array}$ & Amostras finas, AV-UAV \\
\hline $\begin{array}{c}\text { Microscopia eletrônica } \\
\text { de varredurac }\end{array}$ & $\mu \mathrm{m}$ & Morfologia da superfície & $\begin{array}{c}\text { Carregamento da amostra, } \\
\text { AV-UAV }\end{array}$ \\
\hline $\begin{array}{l}\text { Microscopia eletrônica } \\
\text { transmissão (alta } \\
\text { resolução, varredura por } \\
\text { transmissão) }^{b, d}\end{array}$ & $<100 \mu \mathrm{m}$ & $\begin{array}{c}\text { Morfologia e estrutura } \\
\text { local }\end{array}$ & $\begin{array}{l}\text { Preparação da amostra, } \\
\text { destruição de materiais } \\
\text { orgânicos, AV-UAV }\end{array}$ \\
\hline $\begin{array}{c}\text { Espectroscopia de } \\
\text { dispersão de energia de } \\
\text { raios } \mathrm{X}^{e}\end{array}$ & $>500 \mathrm{~nm}$ & $\begin{array}{c}\text { Composição e mapeamento } \\
\text { elementar }\end{array}$ & $\begin{array}{c}\text { Alguns raios X gerados não } \\
\text { são detectados }\end{array}$ \\
\hline Difração de raios $\mathrm{X}^{h}$ & $\begin{array}{c}\text { Resolução a } \\
\text { escala atômica }\end{array}$ & $\begin{array}{c}\text { Estruturas terciárias de } \\
\text { materiais cristalinos }\end{array}$ & $\begin{array}{c}\text { Só para materiais } \\
\text { cristalinos de baixo } \\
\text { número atômico }\end{array}$ \\
\hline $\begin{array}{c}\text { Espectroscopia } \\
\text { infravermelho, por } \\
\text { refletância total atenuada } \\
\text { com transformada de } \\
\text { Fourier }^{h}\end{array}$ & $\begin{array}{l}\text { Independente da } \\
\text { espessura da } \\
\text { amostra }\end{array}$ & $\begin{array}{l}\text { Estrutura e propriedades } \\
\text { da superfície }\end{array}$ & $\begin{array}{c}\text { Interferência e forte } \\
\text { absorbância da água; baixa } \\
\text { sensibilidade para } \\
\text { nanomateriais }\end{array}$ \\
\hline $\begin{array}{l}\text { Espectroscopia de } \\
\text { emissão de raios } X f\end{array}$ & Poucos $\AA$ & Composição da superfície & AV-UAV \\
\hline $\begin{array}{c}\text { Espectroscopia de } \\
\text { fotoelétrons excitados } \\
\text { por raios } \mathrm{X}^{g}\end{array}$ & $1-5 \mathrm{~nm}$ & $\begin{array}{c}\text { Análise química da } \\
\text { superfície }\end{array}$ & $\begin{array}{l}\text { Pouca resolução espacial, } \\
\text { AV-UAV }\end{array}$ \\
\hline
\end{tabular}

*Profundidade de penetração da fonte de radiação, alto vácuo (AV), ultra-alto vácuo (UAV). ${ }^{a}$ Unterhalt et al. (2002); ${ }^{b}$ Park et al. (2005); 'Duffin et al. (2001), Bernier et al. (2012);

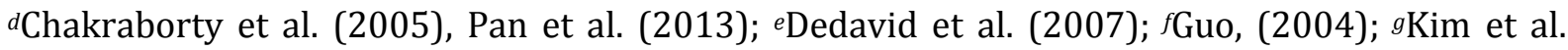
(2005); ' LIN et al. (2014). 


\subsubsection{Estabilidade}

O tamanho, formato, composição química, área superficial, carga, funcionalização e solubilidade, entre outras características, desempenham papéis fundamentais na toxicidade dos nanomateriais, sendo todos afetados/influenciados pela físico-química da água ou do meio onde estão suspendidos (MILLER et al., 2012; BENNETT et al., 2013). 0 tamanho do agregado (e, consequentemente, a taxa de sedimentação) é influenciado pela força iônica e pH via regulação de carga (ADELEYE et al., 2013), mediante o qual a carga superficial repulsiva efetiva dos nanomateriais é diminuída através de blindagem iônica e desprotonação da superfície. Desta forma, as características físico-quimicas dos nanomateriais, entre as quais as mencionadas anteriormente, e as características do meio circundante podem estabilizar ou desestabilizar as partículas em suspensão, e através dos mesmos mecanismos modificar as interações entre os organismos e as nanopartículas (CONWAY et al., 2015).

O estado de dispersão dos sistemas nanoparticulados é outro parâmetro a ser considerado na avaliação da estabilidade das nanopartículas, embora seja um dos mais difíceis de quantificar, pois refere-se ao número relativo (ou massa) das partículas (individuais) no meio de suspensão (POWERS et al., 2006). As partículas individuais podem se manter juntas por interações/forças de atração partícula-partícula (por exemplo, Van der Waals e interações hidrofóbicas), ligação de moléculas adsorvidas (por exemplo, polímeros, proteínas, polissacáridos) ou por meio da interação entre as partículas e o seu ambiente (POWERS et al., 2006). Devido a essas interações, a agregação de nanopartículas pode modificar a sua estabilidade e consequentemente determinar a sua mobilidade, destino, persistência e toxicidade (SALEH et al., 2010).

A agregação pode ser controlada/prevenida por meio de métodos como, por exemplo, ultrassom e agitação, mas estes podem mudar o comportamento das nanopartículas, causando outros efeitos nos organismos expostos (POWERS et al., 2006). A agitação das nanopartículas em suspensão pode aumentar a sua captação em células, devido ao aumento da interação entre eles (HANDY et al., 2012). Outros métodos para evitar a agregação são mediante a utilização de dispersantes, mas a sua utilização pode danificar as células, interferir com os ensaios de toxicidade, alterar a biodisponibilidade e/ou a incorporação das nanopartículas (POWERS et al., 2006). Entre 
os métodos comumente utilizados para caracterizar a estabilidade de sistemas nanoparticulados estão o espalhamento dinâmico de luz (DLS) e a espectrofotometria (CONWAY et al., 2015).

Em resumo, as características físico-químicas dos materiais em escala nanométrica têm potencial para modificar as interações fisiológicas desde o nível molecular até o nível sistémico, tornando o estudo dos efeitos tóxicos decorrentes da exposição aos nanomateriais um assunto de pesquisa importante. Essas interações fisiológicas também podem proporcionar benefícios em aplicações médicas, incluindo avanços na eficácia, redução de efeitos colaterais, prevenção e tratamento de doenças. Neste contexto, a alta produção e utilização dos nanomateriais para diferentes aplicações sugerem a demanda e conhecimento de técnicas robustas que permitam determinar as suas propriedades físico-químicas, tais como, tamanho, superfície, formato, composição, peso molecular, pureza, estabilidade e solubilidade, entre outras. Na Figura 8 estão ilustrados os métodos e técnicas comumente utilizados para a determinação das propriedades físicoquímicas dos nanomateriais.

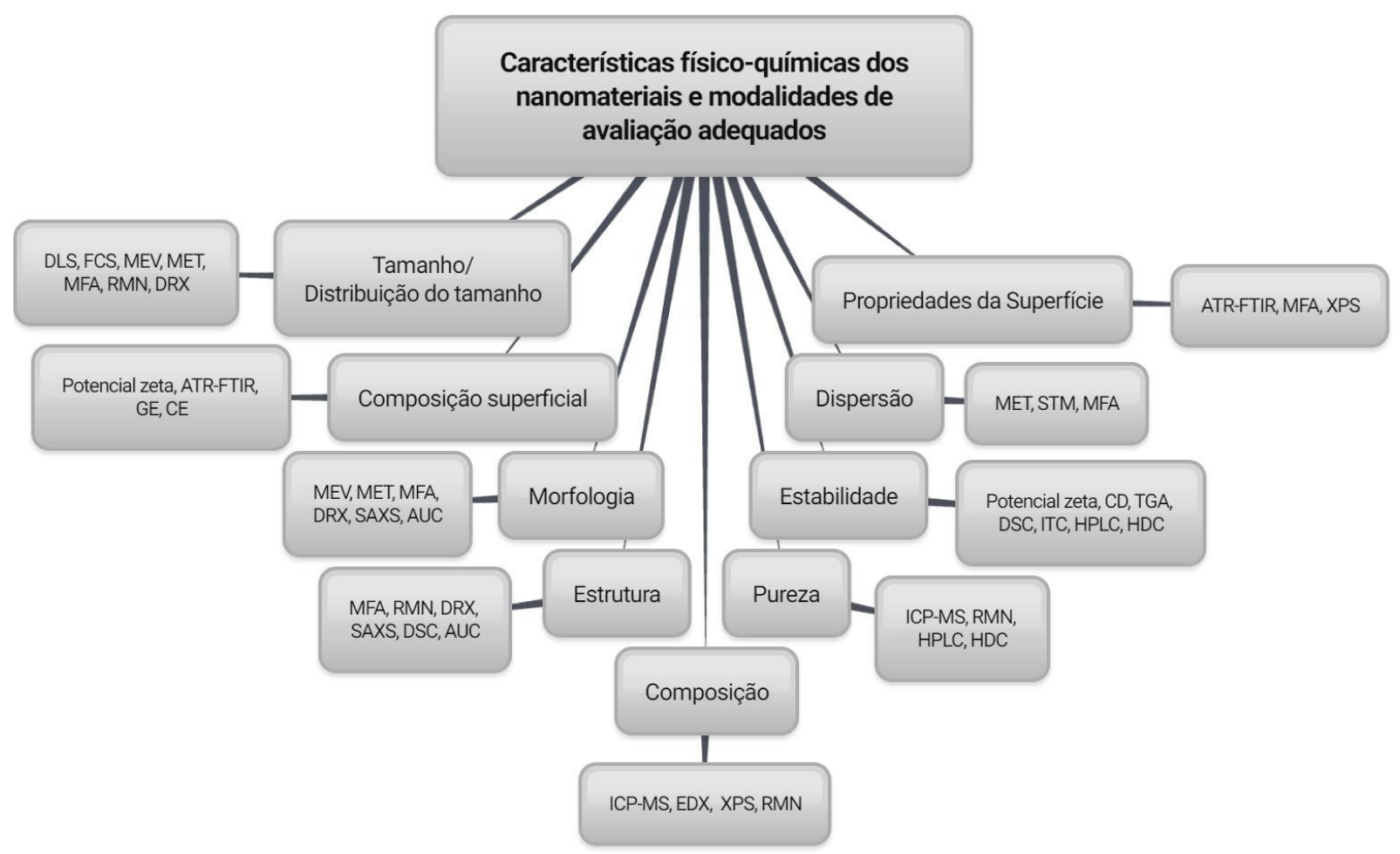

Figura 8. Características físico-químicas dos nanomateriais com os respectivos métodos/técnicas comumente utilizados. Tomado e modificado de Lin e colaboradores (2014). 


\subsection{AS NANOPARTÍCULAS DE PRATA (AgNP)}

Ao longo da história humana a prata tem sido reconhecida por suas diferentes propriedades úteis, como fabricação de moedas, ornamentos, jóias, vasos para vinho e água, aplicação medicinal, incluindo o tratamento de úlceras nos séculos 17 e 18 (YU et al., 2013). Em 1884, o nitrito de prata foi utilizado para evitar a conjuntivite gonocócica em bebês recém-nascidos; em 1967, foi introduzida a sulfadiazina de prata no tratamento de pacientes com queimaduras, permanecendo como o medicamento mais utilizado para feridas de queimaduras serosas (KLASEN, 2000).

A prata é um elemento extremamente raro na crosta terrestre, o que significa que as concentrações são extremamente baixas. Assim, a adição de apenas uma pequena massa de prata a um corpo de água a partir de atividades humanas resultará em grandes impactos em relação às condições naturais (LUOMA, 2008).

Em 1976, foi realizada a inclusão da prata na lista de substâncias perigosas (76/464/EEC) da Comunidade Econômica Europeia (EEC). Desde 1977 até os dias atuais, foi também designada como um poluente em águas naturais pela Agência de Proteção Ambiental dos Estados Unidos (US EPA). Por esta razão, a devida atenção deve ser dada ao seu processo de manufatura, transporte, armazenamento e descarte.

Os critérios norte-americanos de qualidade da água do ambiente sugerem que a vida aquática não será prejudicada se as concentrações de prata não excederem os 3,2 e 1,9 $\mathrm{\mu g} / \mathrm{L}$ em água doce e águas costeiras, respectivamente (US EPA, 2002). Segundo o informe realizado em 1996 pelo Ministério do Meio Ambiente pra Columbia Britânica, os critérios de qualidade da água recomendados para a protecção da vida marinha e água doce estão entre 1,5-3,0 $\mu \mathrm{g} / \mathrm{L}$ e 0,05-3,0 $\mu \mathrm{g} / \mathrm{L}$ de prata total, respectivamente. Nas diretrizes canadenses de qualidade da água para a proteção da vida aquática (2015), foi estabelecido que a concentração tóxica máxima aceitável em longo prazo (MATC) para a prata em água doce pode variar de 0,24 a 1,33 $\mu \mathrm{g} / \mathrm{L}$ para peixes (crescimento) e 0,78 $\mu \mathrm{g} / \mathrm{L}$ para invertebrados (reprodução). A concentração sem efeito observado (NOEC) pode variar de 4 a $13 \mu \mathrm{g} / \mathrm{L}$ para invertebrados, enquanto que a IC20 de invertebrados como Daphnia magna foi estabelecida em 2,95 $\mu \mathrm{g} / \mathrm{L}$. Nessa diretriz também foi estabelecido que as concentrações que causam efeitos tóxicos a longo prazo para a prata 
variam de 1,9 a $23 \mu \mathrm{g} / \mathrm{L}$ para peixes e $0,63 \mu \mathrm{g} / \mathrm{L}$ (MATC) para as plantas.

Os efeitos adversos da exposição crônica à prata coloidal são a coloração cinzaazulada permanente da pele (argiria) ou olhos (argirosis) (IRIS, 1996), resultantes principalmente da exposição às formas solúveis de prata. Além de argiria e argirosis, a exposição a compostos solúveis de prata podem produzir outros efeitos tóxicos, incluindo danos no fígado e nos rins, irritação dos olhos, pele, trato respiratório e intestinal, e alterações nas células sanguíneas (DRAKE E HAZELWOOD, 2005).

A prata nanoparticulada (coloidal) tem sido utilizada por mais de 150 anos e nos Estados Unidos foi registrada como um material biocida desde 1954 (NOWACK et al., 2011). A prata pode formar diferentes complexos orgânicos e inorgânicos, encontrados principalmente (mais estáveis) nos estados de oxidação zero e +1 , embora possam ser encontrados os estados +2 e +3 . 0 nitrato de prata é utilizado frequentemente como um precursor na síntese de diferentes tipos de nanopartículas de prata, as quais possuem uma ampla variedade de formatos (esferas, "rods", fios, triângulos), coberturas (citrato, polímeros, peptídeos, açucares) e tamanhos (REIDY et al., 2013).

Por sua atividade antimicrobiana, antifúngica e antiviral, a prata (nanoparticulada) tornou-se um dos elementos mais utilizados para o desenvolvimento de diferentes produtos nanotecnológicos (FABREGA et al., 2009) entre os quais estão incluídos sabonetes, preservativos, têxteis, máquinas de lavar (DASARI E HWANG, 2010), cateteres, curativos impregnados com prata (CHEN et al., 2006). Por causa disso, há sérias preocupações sobre os riscos ambientais e para a saúde humana advindas da exposição intencional ou inadvertida a esse material, considerando que os produtos que o utilizam podem liberar, ao longo do tempo, prata na forma de íons, nanopartículas e/ou agregados.

Os efeitos tóxicos das nanopartículas de prata em diferentes parâmetros pode ser a consequência da sua capacidade de promover danos às células. A potência das nanopartículas de prata em induzir danos celulares, quando comparados aos íons é dependente do tipo de organismo teste, do tamanho do nanomaterial, entre outros fatores (PARK et al., 2011). As nanopartículas, agregadas ou não, podem ficar na superfície das células, interrompendo seu funcionamento simplesmente pelo contato. 
Também podem atuar como um "Cavalo de Tróia", e uma vez no interior das células podem liberar íons de prata que causariam danos na maquinaria celular (NAVARRO et al., 2008).

As nanopartículas são constituídas por muitos átomos de prata na forma de íons de prata, átomos aglomerados de prata metálica e/ou compostos contendo prata (BALOGH et al., 2001). A grande área superficial é uma propriedade particularmente importante para as nanopartículas de prata, porque pode aumentar a velocidade de liberação de íons, o qual é um dos processos mais importantes a ser considerado em estudos dos possíveis efeitos tóxicos da prata, por ser uma importante via para a sua atividade biológica (LIU et al., 2010; YU et al., 2013). Os íons tem a capacidade de associar-se com outros íons, sendo o próprio íon liberado inerentemente persistente (LUOMA, 2008). A prata iônica é altamente persistente e tóxica para os procariotos (SOTIRIOU E PRATSINIS, 2010), invertebrados marinhos e de água doce (LUOMA et al., 1995) e peixes (LÓPEZ-SERRANO et al., 2014). Além disso, tem uma tendência acentuada para acumular-se nos organismos. Isso devido às suas propriedades químicas que permitem a sua absorção através de proteínas transportadoras da membrana celular, um processo similar ao regulador do transporte de íons $\mathrm{Na}^{+}$e $\mathrm{Cu}^{+}$nas células (BURY, 2009). Entretanto, as nanopartículas de prata não são necessariamente persistentes, pois, podem se dissolver e desagregar, perdendo as propriedades da partícula (LUOMA, 2008; NAVARRO et al., 2008). Nesse sentido, os íons e as nanopartículas de prata são espécies de prata diferentes.

As AgNP se localizam preferencialmente nas mitocôndrias, levando ao aumento da produção de EROs nesta organela; interrompendo a cadeia de transporte de elétrons; induzindo danos estruturais importantes e baixa produção de ATP (ASHARANI et al., 2009). Do mesmo modo, os íons de prata podem se unir aos grupos tiol das enzimas, como NADH desidrogenase, e interromper a cadeia respiratória em bactérias, gerando espécies reativas de oxigênio (ERO) que podem causar estresse oxidativo e dano celular (ASHARANI et al., 2009; LIU et al., 2010). Além disso, as AgNP podem catalizar a redução do oxigênio durante a fosforilação oxidativa, de oxigênio molecular ao radical ânion superóxido $\left(\mathrm{O}^{2-}\right)$. Este radical pode ser convertido em peróxido de hidrogênio $\left(\mathrm{H}_{2} \mathrm{O}_{2}\right)$ e posteriormente ser reduzido a água ou parcialmente reduzido a radical hidroxila $\left(\mathrm{OH}^{-}\right)$, 
um dos oxidantes mais fortes da natureza (BOONSTRA E POST, 2004; ASHARANI et al., 2009). É importante considerar que, as reações entre as AgNP e o $\mathrm{H}_{2} \mathrm{O}_{2}\left(2 \mathrm{Ag}+\mathrm{H}_{2} \mathrm{O}_{2}+\right.$ $2 \mathrm{H}^{+} \rightarrow 2 \mathrm{Ag}^{+}+2 \mathrm{H}_{2} \mathrm{O}$ ) são possivelmente um dos fatores que causam liberação de íons $\mathrm{Ag}^{+}$, aumentando a sua toxicidade (TURRENS, 2003; ASHARANI et al., 2009).

Outras formas de toxicidade causadas pelas nanopartículas de prata podem ocorrer após a aderência das AgNP às membranas celulares ou endocitose, pois há a possibilidade de geração de um fluxo de íons $\left(\mathrm{Ag}^{+}\right)$através das membranas celulares e/ou transporte ativo de $\mathrm{Ag}^{+}$para alvos biológicos sensíveis dentro das células (LIU et al., 2010). Adicionalmente, uma vez realizada a aderência das AgNP às membranas celulares, intermediários do peróxido podem ser gerados, o que poderia oxidar lipídios presentes nas membranas, mas ainda há alguma controvérsia sobre a importância desses mecanismos (LIU E HURT, 2010).

Por outro lado, a prata é conhecida por ter características de um ácido fraco, e há a tendência natural de um ácido reagir com uma base; neste caso, um ácido fraco para reagir com uma base fraca (MORONES E ELECHIGUERRA, 2005; PRABHU E POULOSE, 2012). As células apresentam em sua composição enxofre e fósforo, os quais são bases fracas. Desta maneira, a ação das nanopartículas sobre as células pode fazer com que essa reação tenha lugar, e subsequentemente causar a morte celular. Outro fato importante é que o DNA possui enxofre e fósforo, como componentes principais, e as nanopartículas podem atuar também sobre estes elementos, destruindo o DNA e seguidamente induzindo à morte da célula (HATCHETT E WHITE, 1996; PRABHU E POULOSE, 2012).

\subsection{AS NANOPARTÍCULAS DE PRATA EM AMBIENTES AQUÁTICOS}

O comportamento da prata nanoestruturada em ambientes aquáticos mostra uma ampla variabilidade, pois este depende de fatores como o tamanho, formato e química de superfície, entre outros (LIU et al., 2010). Estudos recentes afirmam que um dos fatores mais importantes a ser considerado é a oxidação das nanopartículas de prata (SOTIRIOU et al., 2012), pois os íons de prata são provenientes dessa oxidação (zero valentes), dada pela reação do oxigênio dissolvido, mediada por prótons e outros componentes presentes na fase líquida (LOK et al., 2007; LIU E HURT, 2010). 
A oxidação da prata é termodinamicamente favorecida à temperatura ambiente $\left(\Delta \mathrm{G}^{0}{ }_{298}=-11,25 \mathrm{~kJ} / \mathrm{mol}\right)$ e tem sido muito estudada, tanto para cristais simples como para nanopartículas (BUKHTIYAROV et al., 2003; BOBROV E GUILLEMOT, 2007; LI et al., 2010). O óxido de prata, quando comparado com a prata metálica, se dissolve mais facilmente em água pura $\left(\mathrm{K}_{\mathrm{ps}}=4 \times 10^{-11}\right)$, resultando na liberação de cátions $\mathrm{Ag}^{+}$ (JOHNSTON et al., 1933). Uma vez que a camada de $\mathrm{Ag}_{2} \mathrm{O}$ é dissolvida, a oxidação/dissolução adicional das AgNP metálicas ocorre apenas na presença de um oxidante na solução (LEVARD et al., 2012). Liu e Hurt (2010) observaram que a remoção de oxigênio dissolvido da água inibe completamente a liberação de íons de prata dissolvidos, demonstrando o papel do $\mathrm{O}_{2}$ na oxidação da superfície das nanopartículas de prata. A reação seguinte foi proposta por Levard e colaboradores (2012), para a dissolução da prata metálica em meio aquoso ácido e aeróbico:

$$
2 \mathrm{Ag}_{(\mathrm{s})}+1 / 2 \mathrm{O}_{2(\mathrm{aq})}+2 \mathrm{H}^{+}{ }_{(\mathrm{aq})} \Leftrightarrow 2 \mathrm{Ag}^{+}(\mathrm{aq})+\mathrm{H}_{2} \mathrm{O}
$$

O íon de prata livre com carga positiva $\left(\mathrm{Ag}^{+}\right)$tem uma forte tendência a associar-se com os íons carregados negativamente em águas naturais, a fim de atingir um estado estável. Em águas naturais pode-se encontrar, principalmente, cinco ligantes aniônicos inorgânicos: fluoreto $\left(\mathrm{F}^{-}\right)$, cloreto $\left(\mathrm{Cl}^{-}\right)$, sulfato $\left(\mathrm{SO}_{4}{ }^{2-}\right)$, hidróxido $\left(\mathrm{OH}^{-}\right)$e carbonato $\left(\mathrm{CO}_{3}{ }^{2-}\right.$ ), que competem pela associação com os metais catiônicos. As ligações também ocorrem com a matéria orgânica dissolvida na água e as constantes de equilíbrio definem a força de cada complexo ligante-metal (LUOMA, 2008). Assim, uma proporção muito pequena do total da prata irá permanecer como prata $\mathrm{Ag}^{+}$(LIU E HURT, 2010) que depende das concentrações dos diferentes ligantes, carregados negativamente, e da força de ligação da $\mathrm{Ag}^{+}$com cada ligante.

$\mathrm{Na}$ água, a especiação da prata é dominada pela concentração de $\mathrm{Cl}^{-}$e, à medida que aumenta a salinidade, os íons livres de $\mathrm{Ag}^{+}$desaparecem ao serem substituídos por uma sequência de complexos de cloreto de prata neutra e aniônica (WOOD et al., 2004). Em água doce, os cloretos estão presentes em baixas concentrações, mas, se há mais átomos de cloreto do que átomos de prata, a prata pode precipitar-se em forma de cloreto de prata, o qual não é disponível para ser absorbido pelos organismos vivos (ADAMS E KRAMER, 1999). Por essa razão, devem ser consideradas avaliações de risco 
da prata acumulada em sedimentos que permitam conhecer as implicações em longo prazo, armazenamento, mobilização, forma e biodisponibilidade de sedimentos.

Em organismos aquáticos, é conhecido que o íon livre $\left(\mathrm{Ag}^{+}\right)$pode causar toxicidade aguda por ligação a sítios específicos nas brânquias, atuando como um análogo ao $\mathrm{Na}^{+}$. Esses locais (ligantes bióticos aniônicos) são proteínas, particularmente $\mathrm{Na}^{+}, \mathrm{K}^{+} \mathrm{ATPase}$, anidrase carbônica, e canais de $\mathrm{Na}^{+}$, que estão intimamente envolvidos no transporte ativo de $\mathrm{Na}^{+}$e $\mathrm{Cl}^{-}$(MORGAN et al., 2004; KALBASSI et al., 2011). Quanto maior a saturação destes locais com $\mathrm{Ag}^{+}$, maior será a toxicidade. Assim, os organismos de água doce expostos à prata estão sujeitos a falhas na regulação iônica (3-24 horas antes de desenvolver patologias) e posteriormente à morte (WOOD et al., 2004).

A prata é significantemente menos tóxica para peixes de água do mar do que de água doce (KALBASSI et al., 2011), embora existam outros fatores que influenciam a tolerância dos organismos teste, tais como, a aclimatação (WOOD et al., 2004). A captação de prata é menor na água do mar do que em água com salinidades intermediárias, mas, em ambos os casos, pode ser acumulada no intestino, bem como no tecido branquial e em órgãos internos, especialmente o fígado (MORGAN et al., 2004; WOOD et al., 2004).

Em resumo, os colóides de prata mais simples podem conter três formas de prata: metálica $\left(\mathrm{Ag}^{0}\right), \mathrm{Ag}$ livre $\left(\mathrm{Ag}^{+}\right)$ou seus complexos, e $\mathrm{Ag}^{+}$adsorvida na superfície das nanopartículas. Isso provavelmente fará com que se apresentem mudanças na sua biodisponibilidade, diferentes características de destino e transporte, com vias de toxicidade independentes ou sinérgicas (LIU E HURT, 2010).

\subsubsection{Efeitos Tóxicos das Nanopartículas de Prata em Organismos Aquáticos}

Em sistemas aquáticos, formas iônicas da prata podem induzir toxicidade em organismos sensíveis a baixas concentrações (na ordem de $\mu \mathrm{mol} / \mathrm{L}$ ) e, como resultado, a concentração limiar da prata, que em critérios de qualidade de água e diretrizes, é baixa em relação à de outros metais (WOOD et al., 1999; BIANCHINI et al., 2002). Embora exista a preocupação sobre a caracterização dos efeitos tóxicos decorrentes da exposição às AgNP, uma compreensão mais abrangente ainda é necessária, isto 
principalmente devido à complexidade do seu comportamento em sistemas aquáticos. Do mesmo modo que para outros nanomateriais, os fatores que tem sido identificados como mais importantes na avaliação da toxicidade são o tamanho, o formato, a área superficial, o comportamento no meio (aglomeração, oxidação e dissolução), a pureza e a influencia das coberturas utilizadas (REIDY et al., 2013).

Hoje em dia vários pesquisadores estão focando seus estudos no esclarecimento das incertezas sobre os mecanismos de toxicidade das AgNP, centrando-se principalmente em propriedades como a adsorção e a absorção. Um exemplo é o estudo realizado por Leclerc e Wilkinson (2014) onde foi encontrado que as Chlamydomonas reinhardtii expostas às AgNP aumentaram a incorporação de prata, quando incrementada a oxidação das nanopartículas na superfície da célula, mas apenas a espécie $\mathrm{Ag}^{+}$foi considerada como a espécie que conseguiu entrar nas células. Por outro lado, no estudo realizado por Khan e colaboradores (2015) foi estudada a dinâmica de bioacumulação de AgNP recobertas com PVP, PEG e citrato, em comparação com a Ag dissolvida, em Daphnia magna e Lumbriculus variegatus. As constantes de velocidade de incorporação para as AgNP foram 2-10 vezes inferior do que para a Ag dissolvida, tanto para D. magna como para L. variegatus. Assim, a toxicidade causada pelas AgNP é mediada principalmente pela dissolução das nanopartículas no meio ou após a incorporação pelos organismos teste, em concordância com os resultados obtidos por Völker e colaboradores (2014), em S. córneo; e por Jo e colaboradores (2012), em Daphnia magna.

Allen e colaboradores (2010) encontraram que a toxicidade aguda (48h $\mathrm{CL}_{50}$ ) das AgNP com cobertura de citrato e do $\mathrm{AgNO}_{3}$ foram semelhantes $(1,1 \mathrm{mg} / \mathrm{L} \mathrm{de} \mathrm{Ag}$ ) em Daphnia magna, incluindo nanopartículas de prata acumuladas no seu interior. Embora os autores não chegassem a esta conclusão, os resultados sugerem que tanto as AgNP como a $\mathrm{Ag}^{+}$liberada a partir das nanopartículas foram responsáveis pela toxicidade. Em contraste, a expressão hepática de genes relacionados com o estresse, em peixes medaka (Oryzias latipes), diferiu entre os organismos expostos a $1 \mathrm{mg} / \mathrm{L}$ tanto de AgNP como de $\mathrm{AgNO}_{3}$ após o primeiro dia de exposição, mas em dias subsequentes foram semelhantes (CHAE et al., 2009a). Outro estudo realizado em mexilhão de água doce (Elliptio complanata) indicou que a exposição às $\operatorname{AgNP}(0,8 ; 4$ e $20 \mathrm{mg} / \mathrm{L})$ resultou num conjunto 
de respostas celulares subletais.

Nos estudos de toxicidade aquática é importante considerar as características físico-químicas do meio, sendo a dureza um dos parâmetros mais importantes para avaliação da biodisponibilidade da prata. Segundo o estudo realizado por Stoiber e colaboradores (2015) em L. stagnalis, as AgNP podem incrementar a sua agregação em água moderadamente dura, especialmente quando recobertas com PEG, reduzindo a sua biodisponibilidade em maior medida do que as recobertas com PVP. Adicionalmente, no estudo realizado por Navarro e colaboradores (2015) foi observado que a biodisponibilidade e toxicidade das AgNP é modificada pelo tipo de cobertura utilizada na nanopartícula, modulando as interações entre as AgNP e as algas (Chlamydomonas reinhardtii).

0 organismo teste e as características das nanopartículas de prata, entre outros fatores, podem causar distintos efeitos em diferentes concentrações. Por exemplo, em gastrópodes como o caramujo Physa acuta, que é particularmente uma espécie sensível às AgNP, foi observado durante exposições crônicas insuficiência reprodutiva (baixa produção de ovos) em concentrações acima de 0,01 mg/L (BERNOT E BRANDENBURG, 2013). Testes realizados em Rana catesbeiana (HINTHER et al., 2010) mostraram que as respostas ao estresse e as dinâmicas de sinalização dos hormônios da tireóide foram alteradas em concentrações muito baixas $(0,6 \mathrm{mg} / \mathrm{L})$. Neste contexto, a importância deste tipo de estudos está na determinação de diretrizes de qualidade da água que permitam proteger aos ecossistemas aquáticos da contaminação por nanopartículas de prata.

\subsubsection{Efeitos Tóxicos das Nanopartículas de Prata em Zebrafish}

Um organismo conveniente para estudar o impacto das AgNP em organismos aquáticos é o zebrafish (Danio rerio). Este organismo teste está sendo muito utilizado na avaliação da toxicidade em ecotoxicologia (YANG et al., 2009), e atualmente para testes de toxicidade de nanomateriais (MUTH-KOHNE et al., 2013; OSBORNE et al., 2015). Entre os estudos realizados para avaliar a toxicidade das nanopartículas, podemos citar a pesquisa realizada por Gupta e colaboradores (2016) em embriões expostos a AgNP. Os embriões expostos expressaram níveis mais elevados de alterações morfológicas na 
cauda, no saco vitelínico e no pericárdio.

Da mesma forma, Massarsky e colaboradores (2013) realizaram estudos com zebrafish, determinando que a $\mathrm{CL}_{50}$ para os embriões expostos a AgNP recobertas com poliacrilato foi de 1,180 mg/L, enquanto que para os organismos expostos a $\mathrm{Ag}^{+}, \mathrm{a} \mathrm{CL}_{50}$ foi de $70 \mathrm{mg} / \mathrm{L}$. As análises demonstram que a toxicidade aguda das AgNP para embriões de zebrafish é principalmente mediada pela liberação de $\mathrm{Ag}^{+}$. A influência do tamanho das partículas e do tipo de revestimento pode, pelo menos parcialmente, explicar as diferenças na dissolução de $\mathrm{Ag}^{+}$(GROH et al., 2014).

Coletivamente, os resultados atuais apontam que a toxicidade é dependente do tamanho das AgNP. De modo que as AgNP menores ( $9 \pm 2 \mathrm{~nm}$ ) podem induzir um aumento muito maior nas taxas de mortalidade e diminuição das taxas de eclosão do que as partículas maiores $(30 \pm 5 \mathrm{~nm})$, dependendo das concentração testadas (MOSSELHY et al., 2016). Além disso, as $\mathrm{AgNP}$ e o $\mathrm{AgNO}_{3}$ induzem diferentes efeitos nas taxas de mortalidade e eclodibilidade. Também foram observados defeitos fenotípicos induzidos pelas AgNP e pelo $\mathrm{AgNO}_{3}$, tais como deformação axial e deposição de $\mathrm{Ag}^{+}$no córion embrionário, respectivamente. Assim, Mosselhy e colaboradores (2016) propuseram que as $\mathrm{AgNP}$ e o $\mathrm{AgNO}_{3}$ induzem diferentes graus e tipos de toxicidade in vivo.

Os perfis de expressão de genes nas brânquias de zebrafish adultos são diferentes para os organismos expostos às AgNP e ao $\mathrm{AgNO}_{3}$, sugerindo que a interação biológica dos nanomateriais é única (GRIFFITT et al., 2009). A observação de respostas específicas para organismos expostos a AgNP e a $\mathrm{Ag}^{+}$, também foram encontradas por Powers e colaboradores (2011) para parâmetros de neurotoxicidade, no desenvolvimento de embriões de D. rerio.

Estudos realizados por Bacchetta e colaboradores (2016) em zebrafish adultos, mostraram que as AgNP se acumulam principalmente nas brânquias, mas não foi encontrada evidência de toxicidade em termos de estresse oxidativo. Em contraste, no estudo realizado por Krishnaraj e colaboradores (2016), além do estresse oxidativo e a imunotoxicidade, foi observado efeito genotóxico, bem como presença de micronúcleos e anormalidades nucleares em células de sangue periférico. Osborne e colaboradores 
(2015) observaram maior redução na actividade da ATPase em peixes expostos a partículas de $20 \mathrm{~nm}$, do que nos expostos a partículas de tamanho maior ou expostos ao $\mathrm{AgNO}_{3}$. Estes resultados demonstram a importância do conhecimento de características da partícula, por exemplo, como o tamanho para a determinação do impacto das AgNP em diferentes órgãos, tais como brânquias e intestino de $D$. rerio.

No geral, os estudos de genotoxicidade e citotoxicidade têm contribuído para o entendimento dos efeitos causados pelas AgNP, pois estes variam consideravelmente, dependendo das características das nanopartículas, do organismo teste e dos parâmetros selecionados para o estudo (SCHULTZ et al., 2014).

\subsection{O ÁCIDO HÚMICO (AH)}

A matéria orgânica natural (MON) é amplamente distribuída nos solos, águas naturais e sedimentos. Mudanças hidrológicas e da composição do solo influenciam a quantidade de matéria orgânica em ambientes aquáticos e a sua natureza química, podendo provocar diferentes efeitos biogeoquímicos no ecossistema (CÉSAR E AZEVEDO, 2008). A concentração natural de matéria orgânica (MO) nas águas superficiais varia tipicamente ENTRE 0,1-20 mg/L (RODRIGUES et al., 2009) e é composta principalmente de substâncias húmicas $(\mathrm{SH})$ que podem ser encontradas amplamente distribuídas ao longo da superfície da terra, na matéria orgânica dos sedimentos terrestres e aquáticos (LITVIN et al., 2012). As SH parecem ser o tipo mais importante de compostos orgânicos no que diz respeito à sua capacidade para formar complexos estáveis com íons metálicos. Por causa do seu potencial de complexação e sua abundância em águas naturais, as substâncias húmicas são de grande interesse na eliminação dos resíduos tóxicos (BOGGS et al., 1985).

As substâncias húmicas diferem de outras substâncias orgânicas encontradas em solos e águas naturais, porque elas já não possuem as propriedades físicas e químicas específicas que caracterizam os compostos orgânicos. As SH são de cor escura, ácidas, predominantemente aromáticas [contendo um ou mais anéis de benzeno $\left(\mathrm{C}_{6} \mathrm{H}_{6}\right)$ ], hidrofílicas (moléculas polares); quimicamente são materiais complexos, e com propriedades de polieletrólitos que variam em peso molecular (SCHNITZER E KHAN, 1978). Stumm e Morgan (1995) descreveram as substâncias húmicas como polímeros 
(300 a $30.000 \mathrm{~g} / \mathrm{mol}$ ) contendo grupamentos fenólicos $(\mathrm{OH})$ e carboxílicos, com um menor número de $\mathrm{OH}$ alifáticos, amino e quinonas (RODRIGUES et al., 2009). Por causa disso, as SH não apresentam características químicas e físicas bem definidas.

Baseados nas suas características de solubilidade, as SH se classificam em ácidos húmicos (AH), ácidos fúlvicos e huminas, (VOETS et al., 2004). 0 ácido húmico (Figura 9) é uma SH solúvel em solventes básicos e insolúvel em condições ácidas (RODRIGUES et al., 2009). As características físicas e químicas de ácidos húmicos dependem de muitos fatores, tais como a procedência do material original, as condições climáticas (zona tropical, subtropical, moderada ou fria), a acidez e o grau de umidade do solo, podendo variar em relação à composição elementar (LANDGRAF et al., 1999).

O ácido húmico é conhecido como um agente oxidante, capaz de formar nanopartículas de prata através da redução de íons de prata à temperatura ambiente (AKAIGHE et al., 2011). 0 caráter oxidante, além de outras propriedades físico-químicas do ácido húmico, pode variar consideravelmente dependendo da sua origem; por exemplo, os ácidos húmicos sedimentares tem a capacidade de reduzir os íons de prata a $22^{\circ} \mathrm{C}$, enquanto que os ácidos húmicos de amostras de solo causam o mesmo efeito a temperaturas muito mais elevadas $\left(90^{\circ} \mathrm{C}\right)$ (AKAIGHE et al., 2011). Devido à ampla variabilidade das características físicas e químicas das $\mathrm{SH}$, estas podem lhe conferir funções específicas em ecossistemas aquáticos e terrestres. Assim, as SH são conhecidas por desempenharem um papel importante nos ciclos geoquímicos de muitos compostos orgânicos e inorgânicos, devido ao seu comportamento eletroquímico e troca iônica (ANGEL et al., 2013).

O AH presente na água possui uma carga eléctrica negativa (potencial zeta), associada à dissociação dos grupamentos fenólicos e carboxílicos, que podem ser determinados por mobilidade eletroforética (WARWICK et al., 2001). Na presença de cátions bivalentes (por exemplo, cálcio) o AH forma agregados intra e intermoleculares devido à neutralização de cargas. Esta hipótese é corroborada por Rodrigues e colaboradores (2009), os quais observaram um aumento do potencial zeta (tornou-se menos negativo) com o aumento das concentrações de cálcio e magnésio no meio, indicando instabilidade da suspensão, principalmente em pH básico. 


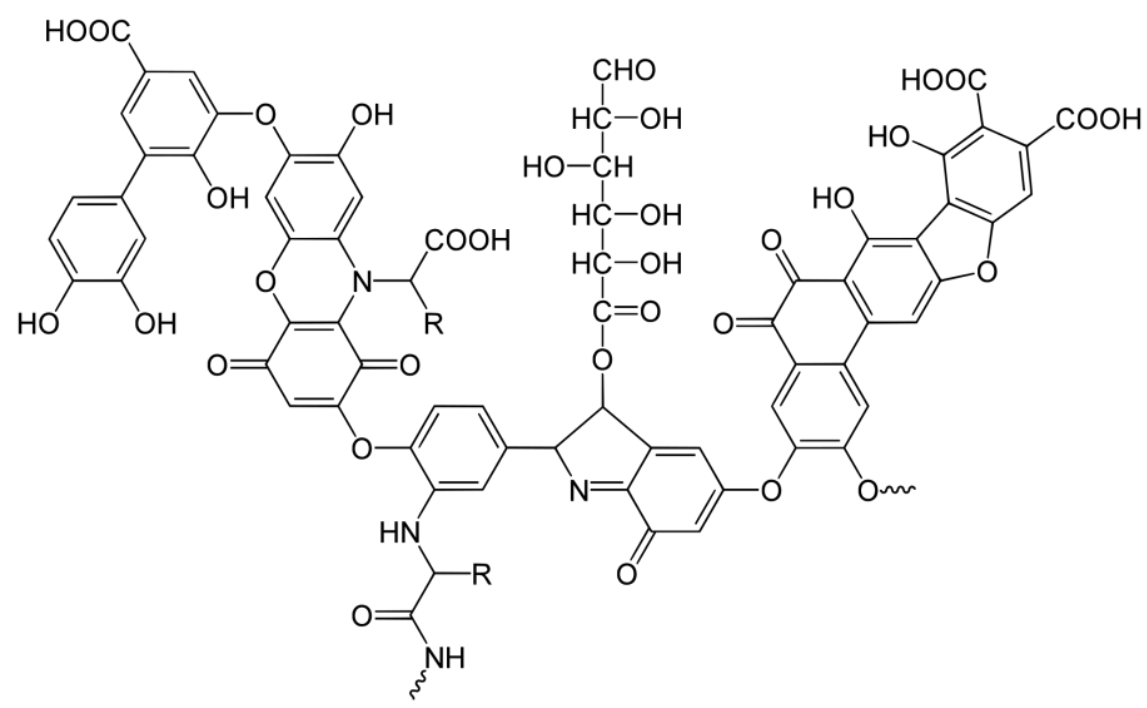

Figura 9. Estrutura proposta para uma molécula típica de ácido húmico, tendo uma variedade de componentes incluindo a quinona, fenol, catecol e açúcar. Tomado de Stevenson (1994).

Os principais sítios de complexação da molécula do AH são os grupamentos carboxílicos e fenólicos. As interações possíveis entre o complexante e os metais podem ter a forma de uma reação de adsorção catiônica via atração eletrostática, como as entre os grupamentos carboxílicos carregados negativamente (dissociados) e um cátion monovalente, ou interações mais complexas (RODRIGUES et al., 2009). As características da molécula orgânica, tais como densidade e tipo de grupamentos reativos, localização dos grupamentos reativos na molécula e tamanho da molécula, e características da solução, tais como $\mathrm{pH}$, força iônica e temperatura, terão grande influência sobre a ocorrência e predominância de determinado mecanismo e a sua estabilidade (NOVAIS et al., 2007).

A constante de formação para a reação entre $\mathrm{um} \mathrm{Ag}^{+}$e as $\mathrm{SH}^{-}$é alta $(\log \mathrm{K} \approx 13)$, sendo de magnitude similar para vários compostos de sulfetos orgânicos, como tióis. Desta maneira, os complexos formados entre a prata (I) e sulfetos são muito fortes (ADAMS E KRAMER, 1999). De igual maneira que para outros metais, a presença de matéria orgânica pode mudar (diminuir) a biodisponibilidade da prata, pela possível formação de um complexo forte com a Ag, o qual pode modificar a acumulação da prata ao longo do tempo (MORGAN et al., 2004). De acordo com o anterior, em ambientes naturais, as nanopartículas podem formar sedimentos pela adsorção à matéria orgânica (TAN, 2003), alterando a biodisponibilidade e toxicidade dos metais, entre os quais os íons de prata (LUOMA et al., 1995). 
O ácido húmico pode revestir as nanopartículas, reduzindo a sua aglomeração (HYUNG et al., 2007), influenciando a biodisponibilidade e toxicidade dos xenobióticos (especialmente metais pesados) em organismos aquáticos (BALAREZO et al., 2002; VOETS et al., 2004), tais como Dreissena polymorpha (VOETS et al., 2004), Paracheirodon innesi (TAO et al., 1999), Daphnia magna (KUKKONEN et al., 1989) e Oncorhynchus tshawytscha (HAMMOCK et al., 2003). Também tem sido afirmado que a química da água, incluindo tanto a matéria orgânica natural como a força iônica da água, pode ser de grande impacto sobre a toxicidade e biodisponibilidade das AgNP, atuando como um captador natural de radicais (GAO et al., 2012). Na maioria dos casos, o revestimento das nanopartículas metálicas pelo ácido húmico induz mudanças no comportamento como diminuição no tamanho dos agregados, sugerindo que o ácido húmico presente em ambientes aquáticos pode modificar, em grande medida, a estabilidade das nanopartículas, especificamente no estado de agregação/dispersão (OMAR et al., 2014).

Como descrito anteriormente, a composição química da matéria orgânica pode modificar consideravelmente as taxas de agregação, dissolução e especiação das nanopartículas em ambientes aquáticos. Essas mudanças no comportamento das nanopartículas na presença de matéria orgânica foram observadas em estudos realizados por Gunsolus e colaboradres (2015), Kim e colaboradores (2013) e Fan e colaboradores (2016), utilizando como organismos teste Shewanella oneidensis MR-1 e Oryzias latipes expostos a AgNP, e em Daphnia magna expostas a nano- $\mathrm{TiO}_{2}$. Por outro lado, Wang e colaboradores (2015) realizaram estudos para avaliar a toxicidade das AgNP em diferentes organismos (Raphidocelis subcapitata, Chydorus sphaericus e Danio rerio), encontrando que a carga da superfície das nanopartículas também pode ser modificada (mais negativa) pela presença de determinadas concentrações de substancias húmicas. Portanto, a liberação de íons foi inibida dependendo das concentrações de matéria orgânica $(\mathrm{SH})$ no meio e, por sua vez, os efeitos tóxicos causados pelos íons liberados diminuíram. Esses resultados sugerem que a adsorção das SH nas nanopartículas constitui uma barreira eletrostática que pode limitar as interações entre as partículas e os organismos, reduzindo na maioria dos casos a toxicidade. 
Além da mortalidade e das mudanças no comportamento dos organismos, existem outros parâmetros que se tem considerado para avaliar os efeitos tóxicos decorrentes da exposição aos nanomateriais, tais como, quantificação da incorporação das nanopartículas (CHEN et al., 2015), alterações morfológicas, danos no DNA (CÁCERESVÉLEZ et al., 2015), geração de espécies reativas de oxigênio e danos mitocondriais (LIN et al., 2012). Autores como Lin e colaboradores (2012) e Chen e colaboradores (2015) encontraram que Chlorella sp. e Danio rerio expostos às nanopartículas de oxido de titânio e grafeno, respectivamente, geraram espécies reativas de oxigênio e danos mitocondriais. Estes efeitos foram mitigados significativamente pela presença de $\mathrm{AH}$, bem como a deposição e acumulação desses nanomateriais no córion dos embriões, corroborando a capacidade do AH para mitigar a toxicidade dos nanomateriais.

Gao e colaboradores (2012) realizaram testes in vivo em Daphnia observando também que quando incrementada a concentração de matéria orgânica no meio, a toxicidade das nanopartículas de prata $(50 \mu \mathrm{g} / \mathrm{L} ; \mathrm{pH}$ 7) diminuiu linearmente. Adicionalmente, estes autores realizaram testes de caracterização físico-química encontrando que o total de prata em suspensão incrementa na presença de concentrações menores que $10 \mathrm{mg} / \mathrm{L}$ de carbono orgânico total (TOC), provavelmente pelo aumento da dispersão das partículas no meio. Em contraste, o conteúdo total de prata diminuiu em concentrações de matéria orgânica maiores do que $10 \mathrm{mg} / \mathrm{L}$ de TOC, indicando um incremento na aglomeração e precipitação das nanopartículas acima de essa concentração.

Embora existam uma grande quantidade de estudos onde foram avaliados os efeitos tóxicos dos nanomateriais, em diferentes organismos teste, os estudos onde se avaliam os efeitos tóxicos decorrentes da interação entre as AgNP e o AH em organismos aquáticos são limitados. Entre esses encontram-se os realizados por García-Alonso e colaboradores (2014), Oliver e colaboradores (2014), Chen e colaboradores (2013), e Kim e colaboradores (2013), nos quais foram avaliados os efeitos tóxicos das AgNP na presença de AH, em P. dumerilii, L. stagnalis, Chlamydomonas reinhardtii, Pseudokirchneriella subcapitata e Oryzias latipes. No estudo realizado por Kim e colaboradores (2013) foi observado que a liberação de íons a partir das AgNP representa maior risco de toxicidade do que as próprias AgNP, e que a presença de ácido 
húmico reduz consideravelmente a toxicidade das AgNP em embriões de peixe medaka (Oryzias latipes), devido à sua complexação com os íons de prata.

Em resumo, a adsorção do ácido húmico na superfície das nanopartículas pode afetar a estabilidade e a dissolução das nanopartículas na água, uma vez que pode reduzir consideravelmente a sua biodisponibilidade, absorção, distribuição e toxicidade em organismos aquáticos.

\subsection{ORGANISMO TESTE}

Os peixes estão no último nível trófico das cadeias alimentares aquáticas e são sensíveis às mudanças ambientais, servindo como um bioindicador da qualidade ambiental (DAUTREMEPUITS et al., 2004; TORRES DE LEMOS et al., 2007). Por esta razão, o peixe dulciaquícola $D$. rerio (zebrafish) vem sendo apontado pela literatura científica como um organismo-teste para a avaliação do potencial toxicológico decorrente da exposição a diferentes substâncias tóxicas, incluindo exposição aos nanomateriais, permitindo o desenvolvimento de abordagens de alto rendimento in vivo (SHIN E FISHMAN, 2002; HILL et al., 2005; HENRY et al., 2007; LIN et al., 2011; PETERSON E MACRAE, 2012).

Uma das vantagens da utilização deste peixe é a sua capacidade de se reproduzir, pois cada fêmea produz centenas de ovos num curto espaço de tempo. Além disso, podese acompanhar facilmente todo o desenvolvimento embrionário devido à transparência dos embriões; e realizar-se vários experimentos geracionais, bem como, investigar a evolução de doenças e identificar as causas de doenças associadas (LAMMER et al., 2009; OLIVEIRA et al., 2009; MIONE E TREDE, 2010; ABLAIN E ZON, 2013).

Em contraste com os ensaios desenvolvidos utilizando cultura de células, os estudos em animais vivos permitem conhecer processos de desenvolvimento complexos que atuam ao longo do tempo para formar organismos adultos (HILL et al., 2005; LEE et al., 2013). Além disso, alguns órgãos do zebrafish apresentam similaridades morfológicas e funcionais aos dos seres humanos, como intestino e fígado, e por isso, os mecanismos e as vias patológicas podem ser correlacionadas entre as espécies (SHIN et al., 2002; ALI et al., 2011; LEE et al., 2012). O genoma desse peixe já foi totalmente sequenciado, permitindo estudos com biomarcadores genéticos de genotoxicidade e de 
alterações de expressão gênica (HOWE et al., 2013).

Deste modo, o zebrafish se apresenta como um modelo in vivo alternativo, rápido, de alto rendimento, rentável, facilmente acessível e fiável, que possui uma boa correlação com modelos in vitro (ZHAO et al., 2013). Considerando as vantagens mencionadas anteriormente, o zebrafish foi escolhido no presente estudo como modelo experimental para avaliar a toxicidade das nanopartículas de prata na presença de ácido húmico, durante o desenvolvimento embrio-larval, bem como em peixes adultos. 


\section{$\int$ USTIFICATIVA}

Estima-se que a produção de materiais nanoestruturados excederá em muito o impacto ocasionado pela Revolução Industrial (NEL et al., 2006). Desta maneira, é urgentemente necessária a obtenção de informações sobre o perigo e o risco toxicológico associados à exposição às nanopartículas (OBERDÖRSTER et al., 2005), o que desempenhará um papel importante na afirmação e crescimento da nanotecnologia (MEDEIROS E MATOSO, 2006).

Diferentes tipos de nanomateriais estão sendo incorporados no desenvolvimento de produtos, especialmente as nanopartículas de prata, as quais são muito utilizadas na fabricação de têxteis, materiais para eliminar as bactérias e odor de roupas, embalagens de alimentos e outros itens, onde as propriedades antimicrobianas são desejáveis (YU et al., 2013). Por esta razão, surge a necessidade de pesquisar, em diferentes cenários, os possíveis efeitos tóxicos das AgNP que permitam ajudar na avaliação das utilizações previstas para este material em nanoescala e para tomar medidas sobre a limitação das atividades que possam apresentar um risco excessivo para a saúde humana e para o ambiente.

Mundialmente, variadas discussões no meio científico e governamental estão sendo realizadas sobre a melhor maneira de identificar e caracterizar o potencial efeito toxicológico dos nanomateriais. Estas discussões referem-se à identificação de metodologias e parâmetros para a caracterização do perigo; às necessidades de desenvolvimento de metodologias alternativas de avaliação; à diversidade, custo e disponibilidade dos nanomaterias (YOON et al., 2009), visando garantir a saúde pública e saúde ambiental.

As AgNP, inevitavelmente, podem entrar em contato com ambientes aquáticos 
naturais cujas características físico-químicas são diversas, tais como temperaturas variáveis, $\mathrm{pH}$, intensidade e duração da luz solar, força iônica, concentração de oxigênio molecular dissolvido, concentração e composição da matéria orgânica natural (GUNSOLUS et al., 2015), entre outras. Cada um desses parâmetros físico-químicos tem o potencial de influenciar a estabilidade coloidal das nanopartículas, modificando a dissolução das AgNP (produção de íons $\mathrm{Ag}^{+}$), cujo efeito é relacionado com a sua toxicidade (XIU et al., 2012).

Entre outras potenciais transformações das AgNP em ambientes aquáticos naturais, as menos compreendidas são as relacionadas ao comportamento e toxicidade das nanopartículas na presença de matéria orgânica (nos solos, águas e sedimentos), o que parece ser causado pela alta heterogeneidade dessas substâncias orgânicas. As mudanças hidrológicas e a composição do solo influem na quantidade de matéria orgânica em ambientes aquáticos e na sua natureza química, podendo provocar diferentes efeitos biogeoquímicos no ecossistema (CÉSAR E AZEVEDO, 2008). É importante mencionar que a matéria orgânica natural é constituída entre 70 a $80 \%$ por substâncias húmicas tais como o ácido húmico, o ácido fúlvico e huminas (CÉSAR E AZEVEDO, 2008).

Embora a quantidade de estudos onde se avaliam os efeitos tóxicos dos nanomateriais é cada vez maior, poucos estudos tem sido desenvolvidos para avaliar os efeitos da interação entre o ácido húmico e as AgNP, em organismos aquáticos. Assim, na avaliação dos riscos ambientais dados pela presença de nanomateriais é importante considerar diferentes características do ecossistema, tais como a presença de ácido húmico.

Desta maneira, o presente estudo descreve as propriedades físico-químicas essenciais das AgNP na ausência e na presença do ácido húmico, em diferentes sistemas aquosos; determina os possíveis efeitos advindos da exposição, através da observação da ocorrência de toxicidade (alterações clínicas e comportamentais, ocorrência de morbidade e identificação da CL50), genotoxicidade (fragmentação do DNA, formação de micronúcleos e anormalidades nucleares) e alterações histológicas (brânquias, fígado e intestino), e quantifica a incorporação de AgNP por espectrometria de massas em peixes adultos e larvas de zebrafish (Danio. rerio). 
3.

\section{$\mathbf{O}_{\text {BEтtvos }}$}

\subsection{OBJETIVO GERAL}

Avaliar o comportamento físico-químico das nanopartículas de prata na presença de ácido húmico em meio aquoso e seus possíveis efeitos toxicológicos agudos durante o desenvolvimento embrio-larval e no organismo adulto do zebrafish (Danio rerio), nas mesmas condições.

\subsection{OBJETIVOS ESPECÍFICOS}

- Identificar o tamanho, a composição e o estado químico das nanopartículas de prata;

- Caracterizar o ácido húmico quanto à sua composição química;

- Avaliar a estabilidade das nanopartículas de prata em diferentes meios aquosos contendo ácido húmico;

- Conhecer as modificações na superfície das nanopartículas de prata em diferentes meios aquosos contendo ácido húmico;

- Avaliar a adsorção e modificações do ácido húmico na presença de nanopartículas de prata suspensas em água;

- Quantificar a liberação de íons a partir de nanopartículas de prata com e sem a presença de ácido húmico;

- Identificar as mudanças nos parâmetros físico-químicos da água na presença de nanopartículas de prata e ácido húmico; 
- Determinar a concentração letal média 50\% (CL50-96h) e os possíveis efeitos toxicológicos decorrentes da exposição a nanopartículas de prata com e sem associação ao ácido húmico, durante o desenvolvimento embrio-larval e em peixes adultos;

- Observar o comportamento dos peixes e determinar os sinais clínicos decorrentes da exposição a nanopartículas de prata com e sem associação ao ácido húmico;

- Avaliar o desenvolvimento embrio-larval durante 96 horas da fertilização, mediante a exposição de nanopartículas de prata com e sem a presença de ácido húmico;

- Quantificar e avaliar a incorporação de prata em larvas como consequência da exposição às nanopartículas de prata, com e sem a presença de ácido húmico;

- Determinar as frequências de ocorrências de micronúcleos, anormalidades nucleares e fragmentação do DNA em eritrócitos dos peixes adultos após a exposição às nanopartículas de prata com e sem a presença de ácido húmico;

- Identificar e quantificar possíveis alterações histológicas em brânquias, fígado e intestino dos peixes adultos, após a exposição às nanopartículas de prata com e a presença de ácido húmico;

- Quantificar e avaliar a incorporação/biodistribuição de prata nas brânquias, fígado, intestino, músculo e rim de peixes adultos expostos a nanopartículas de prata, com e sem a presença de ácido húmico. 


\section{4.}

\section{$\mathbf{M}_{\text {aтrRALIs мётоDos }}$}

\subsection{DESENHO EXPERIMENTAL}

O desenho experimental desse estudo está representado na Figura 10. Na Figura 11 pode-se observar o desenho experimental da caracterização físico-química dos matériais testados, e os testes in vivo realizados estão representados na Figura 12.

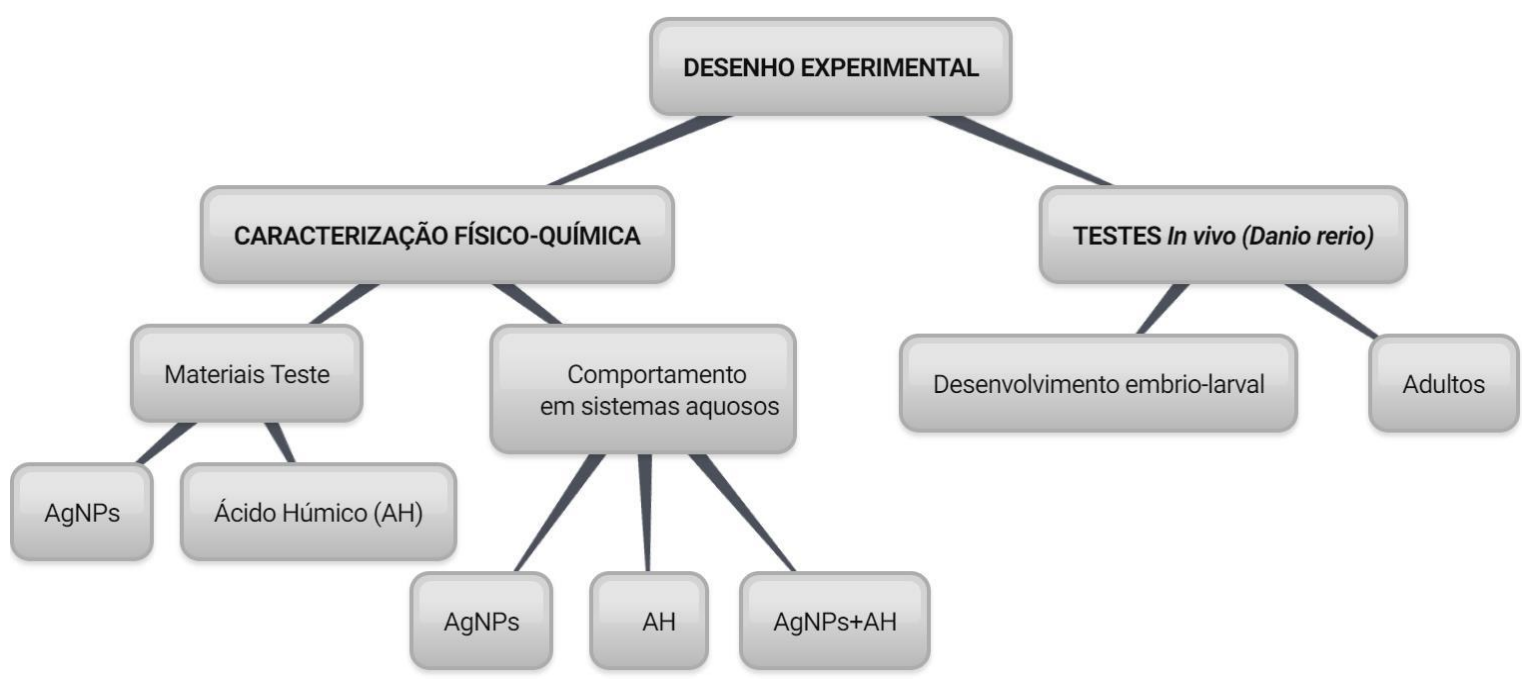

Figura 10. Esquema do desenho experimental geral desse estudo. Nanopartículas de prata (AgNP), ácido húmico $(\mathrm{AH})$ e nanopartículas de prata na presença do ácido húmico (AgNP+AH). 


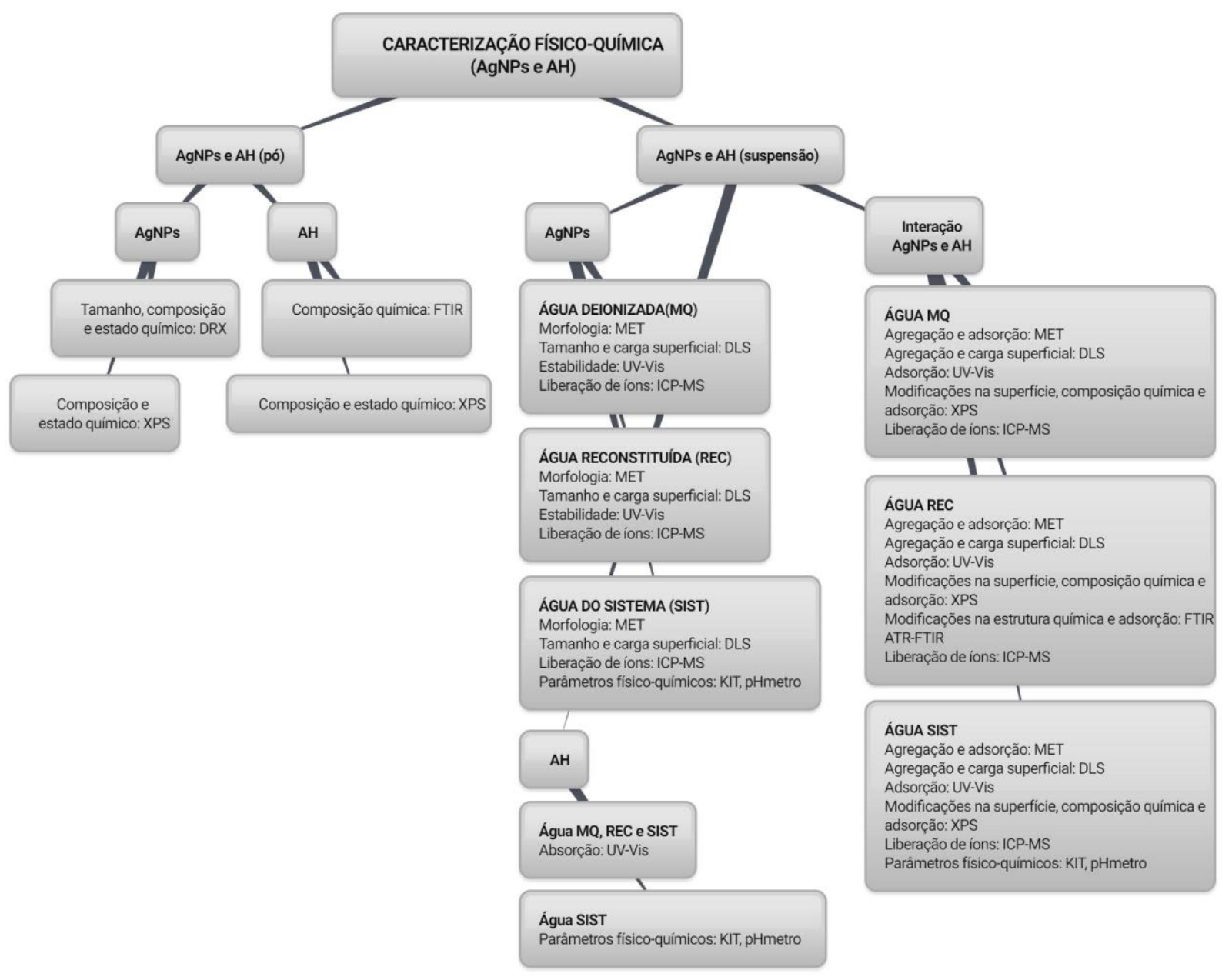

Figura 11. Esquema do desenho experimental da caracterização físico-química dos materiais avaliados nesse estudo. Água deionizada-MQ (NANOpure DIamond de Barnstead, modelo D11931), reconstituída-REC (294 mg/L CaCl $2 . \mathrm{H}_{2} \mathrm{O} ; 123,3 \mathrm{mg} / \mathrm{L} \mathrm{MgSO}_{4} \cdot 7 \mathrm{H}_{2} \mathrm{O} ; 63 \mathrm{mg} / \mathrm{L} \mathrm{NaHCO}{ }_{3}$; 5,5 mg/L KCl), e do sistema-SIST (água de manutenção do Danio rerio), KIT (kit comercial de Labcon ${ }^{\circledR}$ para medição de nitritos, amônia e dureza). 


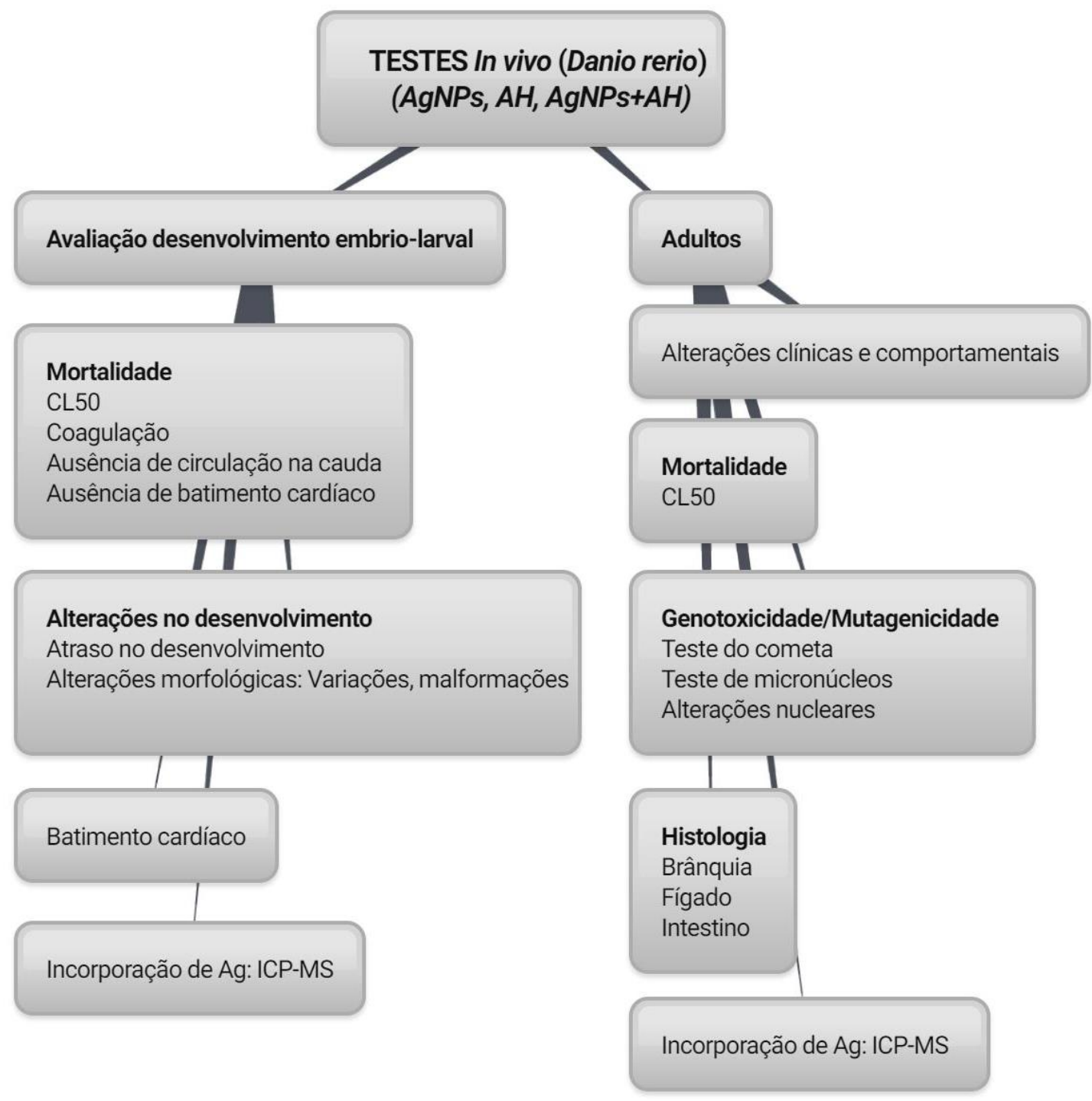

Figura 12. Esquema do desenho experimental dos testes in vivo realizados nesse estudo. Podem-se observar os diferentes parâmetros considerados para avaliação dos efeitos tóxicos, durante o desenvolvimento embrio-larval e em peixes adultos, decorrentes da exposição a AgNP, $\mathrm{AH}$ e AgNP+AH. 


\section{2. ÁGUA UTILIZADA PARA OS DIFERENTES EXPERIMENTOS}

Os testes foram realizados utilizando três tipos de água: água deionizada-MQ (NANOpure DIamond de Barnstead, modelo D11931), reconstituída (REC) e do sistema de manutenção (SIST) do zebrafish (Danio rerio). A água REC foi preparada utilizando água deionizada e uma mistura de sais $\left(294 \mathrm{mg} / \mathrm{L} \mathrm{CaCl}_{2} \cdot \mathrm{H}_{2} \mathrm{O} ; 123,3 \mathrm{mg} / \mathrm{L} \mathrm{MgSO}_{4} .7 \mathrm{H}_{2} \mathrm{O}\right.$; $63 \mathrm{mg} / \mathrm{L} \mathrm{NaHCO}_{3} ; 5,5 \mathrm{mg} / \mathrm{L} \mathrm{KCl}$ ) simulando a água doce, de acordo com o proposto por López-Serrano e colaboradores (2014).

A água do sistema de manutenção do zebrafish é água proveniente da rede de abastecimento comum, previamente tratada com um sistema de filtros de carvão ativado para a retirada do cloro. Após as demais impurezas da água foram removidas pela utilização de filtro de nitrocelulose e posterior utilização do filtro de luz ultravioleta. Os parâmetros físico-químicos da água de manutenção do zebrafish estão dentro dos parâmetros estabelecidos pela OECD 203 (1992). A caracterização da água MQ, REC e SIST foi realizada por ICP-MS a fim de conhecer a concentração de prata, cálcio, potássio, magnésio e sódio.

\subsection{NANOPARTÍCULAS DE PRATA E ÁCIDO HÚMICO}

As nanopartículas de prata "silver nanopowder", (CAS Number 7440-22-4) e o ácido húmico, sal sódico, (CAS Number 68131-04-4) foram obtidos da SIGMA. Os protocolos de preparo desses materiais estão descritos para cada um dos testes realizados.

\subsection{CARACTERIZAÇÃo DAS NANOPARTÍCULAS DE PRATA E DO ÁCIDO HÚMICO}

\subsubsection{Caracterização da morfologia das nanopartículas de prata}

Amostras de nanopartículas de prata (AgNP) foram caracterizadas quanto à morfologia, utilizando-se microscopia eletrônica de transmissão (MET). Para tanto, foram colocados 0,63 mg de AgNP em $25 \mathrm{~mL}$ de água MQ, e as misturas foram sonicadas durante 40 minutos (Vibra-CellTM 75042, $20 \mathrm{kHz}, 500 \mathrm{~W}$ ). Posteriormente, uma alíquota de $10 \mathrm{~mL}$ da mistura anterior foi adicionada a $40 \mathrm{~mL}$ de água MQ. Em seguida, foi realizada uma diluição de 450:150 (água MQ: solução AgNP). Após, $3 \mu \mathrm{L}$ da diluição 
foram colocados sobre uma tela de microscopia eletrônica previamente recoberta com Formvar. As amostras de AgNP foram analisadas no microscópio eletrônico JEOL (JEM1011, UnB - Brasília, Brasil). Os diâmetros de 543 AgNP foram obtidos por análise no programa computacional Motic Images Plus 2.0. A distribuição de diâmetros das partículas foi obtida utilizando-se o melhor ajuste de distribuição log-normal como descrito por Limpert e colaboradores (2001), utilizando a fórmula de Sturges (4).

$\mathrm{k}=1+3,322 \log n$

Onde,

$\boldsymbol{n}$ : número de nanopartículas analisadas.

\subsubsection{Estudo das características cristalinas das nanopartículas de prata}

A caracterização da cristalinidade das AgNP foi realizada por DRX. Pode-se confirmar a presença de $\mathrm{Ag}^{0}$ e obter o tamanho de cristalito das nanaopartículas. Os ensaios de difração de raios X foram realizados em um difratômetro Rigaku - Ultima IV (UnB - Brasília, Brasil), com velocidade do goniômetro de $4^{\circ} / \mathrm{min}$, tubo de cobre (35 $\mathrm{Kv} / 15 \mathrm{~mA}$ ), varrendo-se de 2 a $80^{\circ}$ (escala $2 \theta$ ) com passo de $0,05^{\circ}$. Para análise da fase cristalográfica e determinação do diâmetro médio das nanopartículas foram considerados os 4 picos presentes no difratograma. As posições angulares dos picos de Bragg da amostra foram comparadas com aqueles apresentados pela AMCSD (http://rruff.geo.arizona.edu/AMS/xtal_data/DIFfiles/12873.txt) para prata metálica. Para determinar o diâmetro médio das nanopartículas utilizou-se o método gráfico de Williamson-Hall (Williamson-Hall plot). Os dados das larguras à meia-altura (full width at half maximum - FWHM) dos quatro picos presentes no difratograma, utilizados neste método, foram obtidos por ajuste numérico de funções de pico compostas por lorentzianas e gaussianas utilizando o software PEAKOC 1.0.

\subsubsection{Análise da composição química superficial das nanopartículas de prata e do ácido húmico}

A avaliação da composição química das AgNP (camadas superficiais) e do ácido húmico $(\mathrm{AH})$ em pó foi realizada por XPS. Tal análise foi realizada no espectrômetro SPECS Sage HR 100 (CICBiomaGUNE - San Sebastián, Espanha) com fonte de raios X não 
monocromático (Linha de magnésio K $\alpha$ de 1253,6 eV de energia e $250 \mathrm{~W}$ ) e calibrado usando a linha de $3 \mathrm{~d}_{5 / 2}$ de Ag com uma largura à meia altura (FWHM) de 1,1 eV. A resolução selecionada para os espectros foi de $15 \mathrm{eV}$ e 0,15 eV/step. Todas as medidas foram realizadas em uma câmara de "ultra high vacum" (UHV) a uma pressão de 8x10-8 mbar. Um beamer de projeção eletrônica foi utilizado para compensar o carregamento durante a obtenção de dados de XPS. Foram utilizadas funções Gaussian-Lorentizan (depois de uma correção de base Shirley), onde a FWHM dos picos foram restritas enquanto que as posições dos picos e as áreas foram liberadas no ajuste dos dados.

\subsubsection{Estudo molecular do ácido húmico}

O AH em pó foi liofilizado para a análise espectroscópica FTIR, seguindo o método da pastilha de sal (em KBr) para amostras sólidas particuladas. A amostra sólida de AH foi pulverizada e misturada com o $\mathrm{KBr}$, seguido da sua prensagem, formando uma pastilha transparente. 0 espectrofotômetro utilizado foi o de infravermelho com transformada de Fourier (FTIR), FTIR Thermo Nicolet 6700 (Thermo Electron Corporation, Thermo Fischer Scientific, Massachusetts, EUA; região de 4.000 a $400 \mathrm{~cm}^{-1}$; ganho 8,0; resolução 4.000; 32 varreduras; CICBiomaGUNE - San Sebastián, Espanha).

A solução de AH (20 mg/L) foi preparada utilizando água MQ para análise por espectroscopia UV-VIS. As medições foram realizadas na faixa de 200 a $600 \mathrm{~nm}$, em cubeta de quartzo, utilizando o espectrofotômetro Jasco-630Bio (CICBiomaGUNE - San Sebastián, Espanha).

\subsection{ESTABILIDADE DAS NANOPARTÍCULAS DE PRATA EM DIFERENTES MEIOS AQUOSOS}

Os experimentos foram realizados a $25^{\circ} \mathrm{C}$; $\mathrm{pH} 7,5 \pm 0,5$ e fotoperíodo de 10 horas claro/14 horas escuro. Para todas as amostras avaliadas as condições de sonicação foram: $20 \mathrm{kHz}, 500 \mathrm{~W}$, pulso 5/3 segundos (ON/OFF), $20 \%$ de amplitude, durante 40 minutos, utilizando o processador ultra-sônico Vibra-CellTM 75042. Os detalhes do preparo de cada amostra avaliadas nos experimentos são fornecidos a seguir. 


\subsubsection{Estudo da estabilidade das nanopartículas em água deionizada em função de diferentes concentrações de $\mathrm{NaCl}$}

O efeito da salinidade na estabilidade das nanopartículas de prata foi avaliado em água proveniente do sistema de manutenção dos peixes (SIST) do Laboratório de Genética Toxicológica do Departamento de Genética e Morfologia (IB-UnB), e em água deionizada (MQ) contendo 0; 0,02; 0,04 e 0,08 M de $\mathrm{NaCl}$ (separadamente), totalizando cinco soluções com diferentes concentrações de $\mathrm{NaCl}$. Posteriormente, em $50 \mathrm{~mL}$ de cada solução foram adicionados $100 \mathrm{mg} / \mathrm{L}$ de AgNP e sonicadas utilizando as condições anteriormente descritas. A agregação das AgNP foi determinada pelo monitoramento da sedimentação de agregados de nanopartículas utilizando o espectrofotômetro UV-VIS (SpectraMax M2, UnB - Brasília, Brasil) com uma cubeta $1 \mathrm{~cm}$ de percurso. As mudanças na absorbância a $400 \mathrm{~nm}$ foram obtidas em função do tempo, após sonicação das amostras, ou seja, 0, 40,60, 80, 100, 120 minutos, 24 e 48 horas. Foram realizadas medições do potencial zeta das amostras, nos mesmos tempos, por espalhamento de luz dinâmico (DLS) no equipamento Malvern Zetasizer Nano-ZS90 (UnB - Brasília, Brasil).

\subsubsection{Estudo da estabilidade das nanopartículas de prata em água do sistema em função de diferentes concentrações de ácido húmico}

Para avaliar a estabilidade das nanopartículas de prata na presença de ácido húmico (AH) foram estabelecidos diferentes experimentos utilizando apenas a água proveniente do sistema de manutenção dos peixes do Laboratório de Genética Toxicológica do Departamento de Genética e Morfologia (IB-UnB). Para tanto, foram preparadas as seguintes amostras: água do sistema contendo diferentes concentrações de AH $(0 ; 12,5 ; 25 ; 50$ e $100 \mathrm{mg} / \mathrm{L})$ e com concentração constante de AgNP (100 mg/L), e uma amostra apenas com AH na concentração de $100 \mathrm{mg} / \mathrm{L}$, totalizando seis amostras (50 mL cada). A agregação das AgNP foi determinada pelo monitoramento da sedimentação de agregados de nanopartículas utilizando o espectrofotômetro UV-VIS (SpectraMax M2; UnB - Brasília, Brasil) com uma cubeta $1 \mathrm{~cm}$ de percurso. As alterações na absorbância a $380 \mathrm{~nm}$ foram obtidas em função do tempo, após sonicação das amostras, ou seja, aos 0, 40, 60, 80, 100, 120 minutos, 24 e 48 horas dos procedimentos. Foram realizadas medições do potencial zeta das nanopartículas de prata, nos mesmos tempos, por espalhamento de luz dinâmico (DLS) no equipamento Malvern Zetasizer 
(Nano-ZS90; UnB - Brasília, Brasil). Adicionalmente, $3 \mu \mathrm{L}$ do sobrenadante de cada amostra foi coletado, às 6 e 24 horas após sonicação, e colocado sobre telas de microscopia eletrônica previamente recoberta com Formvar para posterior análise no microscópio eletrônico JEOL (JEM-1011; UnB - Brasília, Brasil).

\subsubsection{Estudo comparativo da estabilidade das nanopartículas de prata para água deionizada, reconstituída e do sistema com concentração fixa de ácido húmico}

Para este experimento foram utilizadas concentrações fixas de AH (20 mg/L) e de AgNP (30 mg/L) em três tipos de água (MQ, REC e SIST). 0 comportamento e a estabilidade das AgNP em diferentes meios aquosos, com e sem a presença de AH, foram determinados realizando medições do potencial zeta e do diâmetro hidrodinâmico das amostras às 0, 24, 48, 72 e 96 horas após sonicação no equipamento Malvern Zetasizer (Nano-ZS90; UnB - Brasília, Brasil).

As amostras de AgNP foram processadas para observar a possível adsorção do AH nas AgNP por MET. Assim, $3 \mu \mathrm{L}$ de cada amostra foram colocados em telinhas de cobre (300 mesh) para análise por microscopia eletrônica de transmissão (JEOL JEM-2100F; CICBiomaGUNE - San Sebastián, Espanha). As amostras (telinhas) foram preparadas em duplicata a fim de realizar em uma delas contrastação com acetato de uranila (0,05\%). Dessa maneira foi possível observar o $\mathrm{AH}$ presente nas amostras e ao mesmo tempo pode-se comparar com as amostras que não foram contrastadas. Separadamente, uma amostra de AgNP foi preparada em metanol (30 mg/L) e sonicadas durante 5 minutos (utilizando as condições de sonicação descritas anteriormente), para observar o comportamento das nanopartículas em meio orgânico.

\subsection{ADSORÇÃO E MODIFICAÇõES DO ÁCIDO HÚMICO NA PRESENÇA DAS NANOPARTÍCULAS DE PRATA}

\subsubsection{Análise das características moleculares}

A fim de conhecer as modificações estruturais e a adsorção do AH nas AgNP, em água REC, foi realizado utilizando a espectroscopia no infravermelho por refletância total atenuada com transformada de fourier (ATR-FTIR). As medições foram realizadas no espectrofotômetro FTIR Thermo Nicolet 6700 (Thermo Electron Corporation, 
Thermo Fischer Scientific, Massachusetts, EUA; região de 2.000 a $1.200 \mathrm{~cm}^{-1}$; ganho 8,0; resolução 4.000; 34 varreduras; CICBiomaGUNE - San Sebastián, Espanha).

Este experimento foi desenvolvido em três etapas: a primeira foi preparar uma solução de AH (100 mg/L) em água REC, o qual foi depositado no suporte para amostras líquidas (cristal ZnSe para ATR "Smart ARK Accessory") e posteriormente foi obtido o espectro. Na segunda etapa, foi preparada uma suspensão de AgNP (3 mg/mL) em metanol, a qual foi depositada na célula de cristal (suporte ZnSe para ATR) e deixou-se secar a temperatura ambiente. Na terceira etapa, a solução de AH (preparada na primeira etapa) foi colocada sobre o filme seco de AgNP. Os espectros foram obtidos às 1, 2 e 3 horas após ter sido depositada a solução de AH no filme de AgNP. Para a obtenção desses espectros foi realizada a subtração do espectro do filme seco (AgNP) nos espectros da solução de AH adicionada, para ser comparado com o espectro obtido da solução de AH (primeira etapa). Este experimento foi realizado segundo o descrito por Bian e colaboradores (2011).

\subsection{MODIFICAÇÕES NA SUPERFÍCIE DAS NANOPARTÍCULAS DE PRATA EM DIFERENTES MEIOS AQUOSOS}

A fim de verificar a oxidação das AgNP, foram realizados diferentes testes utilizando um espectrômetro de XPS (SPECS Sage HR 100; CICBiomaGUNE - San Sebastián, Espanha). Os experimentos foram realizados a $25{ }^{\circ} \mathrm{C}$; $\mathrm{pH} \quad 7,5 \pm 0,5$ e fotoperíodo de 10 horas claro/14 horas escuro. Todas as amostras foram sonicadas durante 40 minutos, pulso 5/3 segundos (ON/OFF) e 20\% de amplitude (Vibra-CellTM 75042, $20 \mathrm{kHz}, 500 \mathrm{~W}$ ).

No primeiro teste foi avaliada a oxidação das AgNP com e sem a presença de AH. Às amostras de água MQ ou água REC ou água SIST foram adicionados $5 \mathrm{mg} / \mathrm{L}$ de AH. Após solubilização do $\mathrm{AH}$, foram adicionados $5 \mathrm{mg}$ de AgNP em um volume de $5 \mathrm{~mL}$ de cada amostra de água e posteriormente foram sonicadas. No total foram preparadas 6 amostras: AgNP em água MQ (Ag MQ), AgNP em água MQ contendo ácido húmico (Ag AH MQ), AgNP em água REC (Ag REC), AgNP em água REC contendo ácido húmico (Ag AH REC), AgNP em água SIST (Ag SIST), e AgNP em água SIST contendo ácido húmico (Ag AH SIST). As análises foram realizadas às 0 (imediatamente após o preparo da solução), 
24, 48 e 96 horas após sonicação.

Em função de que as AgNP em água REC contendo ácido húmico (Ag AH REC) apresentaram mudanças no estado de oxidação, foi realizado um segundo experimento para avaliar a influência do $\mathrm{AH}$ e cada um dos os sais utilizados para o preparo da água REC na oxidação das AgNP. Para tanto, foi utilizada água MQ para preparar 4 diferentes meios aquosos: água $\mathrm{MQ}$ contendo $\mathrm{CaCl}_{2} \cdot 2 \mathrm{H}_{2} \mathrm{O}(294 \mathrm{mg} / \mathrm{L})$, água $\mathrm{MQ}$ contendo $\mathrm{MgSO}_{4} .7 \mathrm{H}_{2} \mathrm{O}(123,3 \mathrm{mg} / \mathrm{L})$, água MQ contendo $\mathrm{NaHCO}_{3}(63 \mathrm{mg} / \mathrm{L})$, e água MQ contendo $\mathrm{KCl}$ (5,5 mg/L). Posteriormente, a cada amostra de água foram adicionados $5 \mathrm{mg} / \mathrm{L} \mathrm{de}$ AH. Após solubilização do AH, 5 mg de AgNP foram adicionados em um volume de $5 \mathrm{~mL}$ de cada água preparada com posterior sonicação. As análises foram realizadas às 96 horas após sonicação.

Baseados nos resultados do experimento anterior, foi estudada a influência da mistura de sais na oxidação das AgNP (terceiro experimento). Para este experimento foi utilizada água MQ para preparar diferentes meios aquosos, os quais continham mistura diferentes dos sais utilizados para o preparo da água REC. No total foram preparadas 3 amostras: água MQ contendo $63 \mathrm{mg} / \mathrm{L}$ de $\mathrm{NaHCO}_{3}+294 \mathrm{mg} / \mathrm{L} \mathrm{CaCl}_{2} .2 \mathrm{H}_{2} \mathrm{O}$; água $\mathrm{MQ}$ contendo $63 \mathrm{mg} / \mathrm{L}$ de $\mathrm{NaHCO}_{3}+123,3 \mathrm{mg} / \mathrm{L}$ de $\mathrm{MgSO}_{4} .7 \mathrm{H}_{2} \mathrm{O}$; e água MQ contendo 63 $\mathrm{mg} / \mathrm{L}$ de $\mathrm{NaHCO}_{3}+5,5 \mathrm{mg} / \mathrm{L}$ de $\mathrm{KCl}$. A seguir, a cada amostra de água foram adicionados $5 \mathrm{mg} / \mathrm{L}$ de AH. Após solubilização do AH, $5 \mathrm{mg}$ de AgNP foram adicionados em um volume de $5 \mathrm{~mL}$ de cada água preparada seguida de sonicação. As análises foram realizadas às 96 horas após sonicação.

A fim de conhecer se o $\mathrm{AH}$ e as sais foram adsorvidas na superfície das AgNP, em todas as amostras analizadas dos experimentos descritos anteriormente foram realizadas lavagens após 96 horas do preparo. Assim, as amostras foram centrifugadas ( $9.000 \mathrm{x} \mathrm{g} ; 21^{\circ} \mathrm{C} ; 30$ minutos) para remover o sobrenadante e lavadas 3 vezes com água MQ. Cada lavagem foi realizada da seguinte forma: foi retirado o excesso de sobrenadante, imediatamente se adicionaram $5 \mathrm{~mL}$ de água $\mathrm{MQ}$, as amostras foram ressuspendidas com ajuda do vortex e centrifugadas $\left(9.000 \mathrm{x} \mathrm{g} ; 21{ }^{\circ} \mathrm{C} ; 30\right.$ minutos). Depois da última lavagem, foi retirado o máximo possível do sobrenadante, e ao redor de $100 \mu \mathrm{L}$ de cada amostra foram depositados nos suportes, deixando secar durante 16 horas à temperatura ambiente no dessecador. As amostras foram analisadas por XPS no 
espectrômetro SPECS Sage HR 100 com fonte de raios X não monocromática (Linha de magnésio K $\alpha$ de 1253,6 eV de energia e 250 W).

\subsection{ESTUDO DA LIBERAÇÃO DE ÍONS DE PRATA}

A fim de conhecer a liberação de íons a partir de AgNP e AH, foram realizados dois experimentos utilizando água MQ, REC e SIST. A análise quantitativa dos íons de prata foi realizada por espectrometria de massas com plasma indutivamente acoplado (ICPMS). Os experimentos foram conduzidos à temperatura ambiente $\left(20^{\circ} \mathrm{C}\right), \mathrm{pH}$ neutro $(6,8-7,0)$ e fotoperíodo de 10 horas claro/14 horas escuro, e o volume preparado para cada amostra foi de $50 \mathrm{~mL}$.

Em um primeiro momento analisamos diferentes concentrações de AgNP em um tempo fixo (96 horas). Para isso, foi realizada a sonicação (pulso 5/3 segundos (ON/OFF), 20\% de amplitude, durante 40 minutos) de uma solução mãe (10 mg/L) de AgNP preparada nos diferentes tipos de água (MQ, REC e SIST) com ou sem ácido húmico $(20 \mathrm{mg} / \mathrm{L})$, e a partir desta solução foram realizadas diluições de maneira a obtermos as seguintes concentrações finais: 10; 3,0; 1,0; e 0,5 mg/L de AgNP em um volume de $50 \mathrm{~mL}$. 0 sistema foi então deixado em repouso por 96 horas e após esse tempo os íons de prata liberados foram separados.

Para o segundo experimento foram preparadas 6 amostras: AgNP em água MQ sem AH; AgNP em água MQ contendo AH; AgNP em água REC sem AH; AgNP em água REC contendo $\mathrm{AH}$; AgNP em água SIST sem AH; e AgNP em água SIST contendo AH. Cada amostra continha $20 \mathrm{mg} / \mathrm{L}$ de AgNP, com e sem a presença de $20 \mathrm{mg} / \mathrm{L}$ de AH. As amostras foram mantidas em repouso e após 0 (imediatamente após o preparo da solução), 24, 48 e 96 horas do preparo foi realizada a separação dos íons de prata liberados ao meio.

Para os dois experimentos, os íons liberados foram separados das nanopartículas em suspensão utilizando os métodos descritos por Liu e Hurt (2010), George e colaboradores (2012), e López-Serrano e colaboradores (2014), com algumas modificações. A separação foi realizada em duas etapas. A primeira consistiu em realizar duas centrifugações (8.912 x g; $25{ }^{\circ} \mathrm{C} ; 20$ minutos; Allegra ${ }^{\mathrm{TM}} \mathrm{X}-22 \mathrm{R}$, Beckman Coulter, Inc.). Na primeira centrifugação foram utilizados os $50 \mathrm{~mL}$ de cada amostra, e na 
segunda centrifugação foram utilizados $15 \mathrm{~mL}$ do sobrenadante (de cada amostra) resultante da centrifugação anterior. Essa primeira etapa de separação foi realizada a fim de agilizar o processo de separação/precipitação das AgNP, fazendo com que a prata iônica ficasse no sobrenadante. Na segunda etapa foi realizada a ultrafiltração, utilizando filtros Amicon Ultra-4 5K, Millipore (7.500 x g; 20 minutos; $25^{\circ} \mathrm{C}$; rotor fixo; Allegra ${ }^{\mathrm{TM}} \mathrm{X}$ 22R, Beckman Coulter, Inc.), até obter um volume de $10 \mathrm{~mL}$ de filtrado para cada amostra. As análises foram realizadas, para as amostras dos dois experimentos, no espectrômetro de massas com plasma indutivamente acoplado (7700x, Agilent Technologies; Bilbao, Espanha) e os valores médios foram calculados a partir de três medições para cada grupo.

\subsection{AVALIAÇÃO DA TOXICIDADE AGUDA, EM ZEBRAFISH, DE NANOPARTÍCULAS DE PRATA SUSPENSAS EM ÁGUA SIST, COM E SEM A PRESENÇA DE ÁCIDO HÚMICO}

\subsubsection{Manutenção dos Peixes}

Todos os procedimentos seguiram os princípios éticos de experimentação animal, visando evitar ou minimizar o estresse, a angústia, a dor e o desconforto. 0 projeto foi aprovado pelo Comitê de Ética no Uso Animal (CEUA) do Instituto de Biologia da Universidade de Brasília (UnBDoC n66618/2014, ANEXO A). Os procedimentos seguiram as normas para experimentação estabelecidas na Lei Arouca ( $\mathrm{n}$ o 11.794 , de 8 de outubro de 2008) e os procedimentos preconizados na literatura: Usos de Animais de Laboratório" (National Research Council, 1996) e AVMA (2007).

Foram utilizados peixes Danio rerio adultos mantidos no Departamento de Genética e Morfologia (GEM-IB-UnB), em aquários apropriados e utilizando água (previamente tratada) proveniente da rede de abastecimento comum (Item 4.1.). A temperatura foi mantida em torno de $26 \pm 1{ }^{\circ} \mathrm{C}$ com aeração constante; pH 7,5 $\pm 0,5$ e fotoperíodo de 10 horas claro/14 horas escuro. Os animais receberam ração comercial para peixes, duas vezes ao dia. 


\subsubsection{Avaliação da toxicidade aguda no desenvolvimento embrio-larval do zebrafish}

\subsubsection{1. $\quad$ Produção de Ovos}

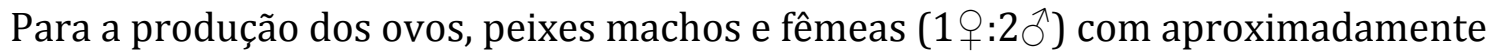
seis meses de idade foram colocados numa caixa de incubação, constituída por um tanque horizontal com divisória para separar os machos das fêmeas. No dia seguinte, a divisória foi removida imediatamente após as luzes terem sido acessas. Os embriões de zebrafish se desenvolvem rapidamente, por tal motivo, os ovos fertilizados foram coletados uma hora depois das luzes terem sido acesas e ovos viáveis foram separados e lavados pelo menos três vezes com água proveniente do meio de cultura. A fim de garantir a sincronização do desenvolvimento no início da exposição, os ovos fertilizados foram identificados pela fase de blástula no desenvolvimento. 3-3,5 horas após a fertilização (hpf); a viabilidade foi avaliada (ovos translúcidos) para distribuí-los aleatoriamente nos grupos experimentais.

\subsubsection{Preparo das Suspensões das Nanopartículas de Prata em Água do Sistema com e sem a Presença de Ácido Húmico}

Para avaliação da toxicidade das diferentes concentrações de AgNP, com e sem a presença de $\mathrm{AH}$ em embriões de zebrafish foi utilizada água do sistema. Para as amostras de AgNP com a presença de $\mathrm{AH}$, a água utilizada foi previamente preparada adicionando AH (a fim de obter uma solução de $20 \mathrm{mg} / \mathrm{L}$ de ácido húmico) na água, agitando a solução até se dissolver. É importante destacar que esta água foi utilizada apenas para o preparo das diferentes amostras de AgNP contendo $\mathrm{AH}$, e para aquelas sem a presença de AH foi utilizada apenas água SIST.

Posteriormente, duas soluções mãe de $10 \mathrm{mg} / \mathrm{L}$ AgNP (cada) foram preparadas, uma com a presença de $20 \mathrm{mg} / \mathrm{L}$ de $\mathrm{AH}$, e outra sem a presença de $\mathrm{AH}$ (apenas água SIST). Seguidamente cada uma foi sonicada durante 40 minutos, pulso 5/3 segundos (ON/OFF) e 20\% de amplitude (Vibra-CellTM 75042, $20 \mathrm{kHz}, 500$ W). A partir destas duas soluções mãe foram realizadas diluições, utilizando também água SIST (com e sem $20 \mathrm{mg} / \mathrm{L}$ de $\mathrm{AH}$ ), de maneira a obtermos as seguintes concentrações finais de AgNP: 
0,$25 ; 0,5 ; 1,0 ; 1,5 ; 2,0 ; 2,5 ; 3,0 ; 4,75 ; 6,5$ e $8,5 \mathrm{mg} / \mathrm{L}$.

Desta forma, as suspensões preparadas foram utilizadas para compor dois grupos experimentais conforme a Tabela 3. Para facilitar a compreensão, nomearemos ao grupo com diferentes concentrações de nanopartículas de prata sem a presença de ácido húmico, como AgNP, e ao grupo com diferentes concentrações de nanopartículas de prata com a presença de ácido húmico, como AgNP+AH.

Tabela 3. Grupos experimentais considerados para avaliação da toxicidade no desenvolvimento embrio-larval mediante a exposição de AgNP, AH e AgNP+AH.

\begin{tabular}{|c|c|c|c|c|c|c|c|c|c|c|c|c|c|}
\hline \multicolumn{14}{|c|}{ GRUPO EXPERIMENTAL AgNP } \\
\hline & \multicolumn{13}{|c|}{ Sub-grupos } \\
\hline \multirow{2}{*}{$\operatorname{AgNP}(\mathrm{mg} / \mathrm{L})$} & Controle & \multicolumn{12}{|c|}{ Tratados } \\
\hline & 0 & & 25 & 0,5 & 1,0 & 1,5 & 2,0 & 2,5 & 3,0 & 4,75 & 6,5 & 8,5 & 10 \\
\hline \multicolumn{14}{|c|}{ GRUPO EXPERIMENTAL AgNP+AH } \\
\hline & \multicolumn{13}{|c|}{ Sub-grupos } \\
\hline $\operatorname{AgNP}(\mathrm{mg} / \mathrm{L})$ & Controle & \multicolumn{12}{|c|}{ Tratados } \\
\hline $\begin{array}{c}+ \\
20 \mathrm{mg} / \mathrm{L} \mathrm{AH}\end{array}$ & 0 & $\mathrm{AH}$ & 0,25 & 0,5 & 1,0 & 1,5 & 2,0 & 2,5 & 3,0 & 4,75 & 6,5 & 8,5 & 10 \\
\hline
\end{tabular}

4.9.2.3. $\quad$ Avaliação da Toxicidade no Desenvolvimento Embrio-Larval do $\underline{\text { Zebrafish }}$

A avaliação do desenvolvimento embrio-larval foi baseada na diretriz "Fish Embryo Acute Toxicity (FET)” da OECD 236 (2013), a fim de determinar a concentração letal média (CL50) das AgNP, com e sem a presença de AH. Os ovos coletados foram distribuídos em dois grandes grupos, sendo um apenas com nanopartículas de prata (AgNP) e o segundo com nanopartículas de prata na presença de ácido húmico $(\mathrm{AgNP}+\mathrm{AH})$, como descrito na Tabela 3.

Os experimentos foram realizados em placas de cultura de 24 poços. Em cada placa (isto é uma placa por concentração), 20 poços foram preenchidos com $2 \mathrm{~mL}$ de AgNP ou $\mathrm{AgNP}+\mathrm{AH}$ e os 4 poços restantes foram preenchidos com $2 \mathrm{~mL}$ de água do sistema de manutenção, constituindo o grupo controle interno de cada placa. Um embrião foi transferido para cada poço da placa. Os experimentos foram realizados em duplicata. 
Todas as placas foram colocadas em uma incubadora de iluminação (SOLAB SL-224) a $26 \pm 1^{\circ} \mathrm{C}$ e fotoperíodo de 10 horas claro/14 horas escuro por até 96 horas.

O desenvolvimento embrio-larval foi monitorado com a ajuda de um microscópio invertido (ZEISS Axio Vert.A1; UnB - Brasília, Brasil), com sistema de captura de imagens acoplado (Carl Zeiss AxioCam MRc), às 24, 48, 72 e 96 horas pós fertilização (hpf). Os parâmetros avaliados foram coagulação (morte), formação dos olhos, otólitos e somitos, movimentos espontâneos, pigmentação do corpo, absorção do saco vitelino, desprendimento da cauda, batimento cardíaco, perda do equilíbrio, edema cardíaco, e malformações na cabeça, coluna e cauda (BAI et al., 2010). Para avaliar as malformações na coluna e na cauda foi considerado o ângulo da cabeça-cauda das larvas (ONG et al., 2017), onde a coluna se assemelha a uma linha reta e as malformações na coluna são identificadas como uma ou mais curvaturas presentes ao longo da coluna vertebral.

A análise macroscópica das larvas foi realizada, também, com o microscópio de eletrônico de varredura JEOL (JSM-700 1F; UnB - Brasília, Brasil). As larvas ( $n=10)$ dos diferentes grupos expostos, com e sem $\mathrm{AH}$, foram eutanasiadas por submersão em água fria $\left(0-4{ }^{\circ} \mathrm{C}\right)$ e seguidamente foram fixadas com o fixador Karnovsky (2\% paraformaldeído, 2\% glutaraldeído, 3\% sacarose, $5 \mathrm{mM}$ cloreto de cálcio em tampão $\mathrm{CaCO}_{3}$ 0,1 M; pH 7,4) durante 5 horas. Posteriormente, as amostras foram armazenadas no tampão $\mathrm{CaCO}_{3}(0,1 \mathrm{M}$; pH 7,4). 0 material foi pós-fixado com tetróxido de ósmio $(4 \%)$ durante 1 hora e imediatamente foram realizadas desidratações graduais utilizando acetona (30,50, 70, 90 e $100 \%)$; e desidratações com o secador ao ponto crítico de $\mathrm{CO}_{2}$ (Balzers CPD 030). As amostras foram dispostas sobre os suportes ("stubs"), previamente identificados e na sequência, a metalização foi realizada no equipamento Balzers (SCD 050). Posteriormente, foi realizada a análise e a captura de imagens.

\subsubsection{Parâmetros Físico-Químicos da Água do Sistema Contendo Nanopartículas de Prata com e Sem a Presença de Ácido Húmico}

Os parâmetros físico-químicos da água do sistema como: temperatura, pH (pHmetro), condutividade (PHTEK CD203), nitritos, amônia e dureza foram avaliados às 96 horas após o preparo das águas contendo AgNP $(0 ; 0,25 ; 0,5 ; 1,0 ; 1,5 ; 2,0 ; 2,5 ; 3,0$; 
4,75; 6,5; 8,5 e $10 \mathrm{mg} / \mathrm{L}$ AgNP), com ou sem a presença de ácido húmico (20 mg/L); água contendo apenas AH (20 mg/L), e água sem a presença dos materiais teste (AgNP, $\mathrm{AgNP}+\mathrm{AH}$ e $\mathrm{AH})$. Os parâmetros físico-químicos foram medidos utilizando os kits comerciais de Labcon $®$.

\subsubsection{Quantificação da Prata nas Larvas de Zebrafish}

A quantificação da prata incorporada nas larvas foi realizada por espectrometria de massas com plasma indutivamente acoplado (ICP-MS). Assim, as larvas dos grupos experimentais $0 ; 0,5 ; 1,0 ; 1,5$ e 3,0 mg/L de AgNP, com e sem a presença de $\mathrm{AH}$, foram eutanasiadas por submersão em água fria $\left(0-4{ }^{\circ} \mathrm{C}\right)$ e seguidamente foram colocadas em microtubos de centrifuga, previamente identificadas para cada grupo, formando pools de 23 larvas por sub-grupo experimental. As larvas foram liofilizadas e seguidamente foi realizada a digestão ácida com $\mathrm{HNO}_{3} 70 \%$ durante 48 horas a temperatura ambiente. As soluções foram transferidas a balões volumétricos $(10 \mathrm{~mL})$ e foram preenchidos até o nível com água $\mathrm{MQ}$, para obter amostras com concentração final de $\mathrm{HNO}_{3} 1 \%$. A análise quantitativa foi realizada no espectrômetro de massas com plasma indutivamente acoplado (7700x, Agilent Technologies; Bilbao, Espanha). Os valores médios foram calculados a partir de cinco repetições para cada sub-grupo. 0 protocolo foi baseado no protocolo proposto por (KRYSTEK, 2012; KIM et al., 2013) com algumas modificações.

\subsubsection{Avaliação da toxicidade aguda em peixes zebrafish adultos}

\subsubsection{Preparo das Nanopartículas de Prata com e sem a Presença de $\underline{\text { AH em Água do Sistema }}$}

Para avaliação da toxicidade das AgNP com e sem a presença de AH em peixes adultos de zebrafish foi utilizada água do sistema. Para as amostras de AgNP com a presença de $\mathrm{AH}$, a água utilizada foi previamente preparada adicionando $\mathrm{AH}$ (a fim de obter uma solução de $20 \mathrm{mg} / \mathrm{L}$ de ácido húmico), agitando a solução até se dissolver. É importante destacar que esta água foi utilizada apenas para o preparo das diferentes amostras de AgNP contendo $\mathrm{AH}$, e para aquelas sem a presença de AH foi utilizada apenas água SIST. 
Posteriormente, duas soluções mãe de $60 \mathrm{mg} / \mathrm{L}$ AgNP (cada) foram preparadas, utilizando numa delas água com a presença de $20 \mathrm{mg} / \mathrm{L}$ de $\mathrm{AH}$ e numa outra sem a presença de AH (apenas água SIST), e seguidamente cada uma foi sonicada durante 40 minutos, pulso 5/3 segundos (ON/OFF) e 20\% de amplitude (Vibra-CellTM 75042, 20 $\mathrm{kHz}, 500 \mathrm{~W}$ ). A partir destas duas soluções mãe foram realizadas diluições, utilizando também água SIST (com e sem $20 \mathrm{mg} / \mathrm{L}$ de $\mathrm{AH}$ ), de maneira a obtermos as seguintes concentrações finais de AgNP: 10, 20, 30 e 40 mg/L.

Desta forma, as suspensões preparadas foram utilizadas para compor dois grupos experimentais conforme a Tabela 4. De igual forma que para os experimentos realizados com embriões, nomearemos ao grupo com diferentes concentrações de nanopartículas de prata sem a presença de ácido húmico, como AgNP, e ao grupo com diferentes concentrações de nanopartículas de prata com a presença de ácido húmico, como $\mathrm{AgNP}+\mathrm{AH}$.

Tabela 4. Grupos experimentais considerados para avaliação da toxicidade em peixes adultos mediante a exposição de AgNP, AH e AgNP+AH.

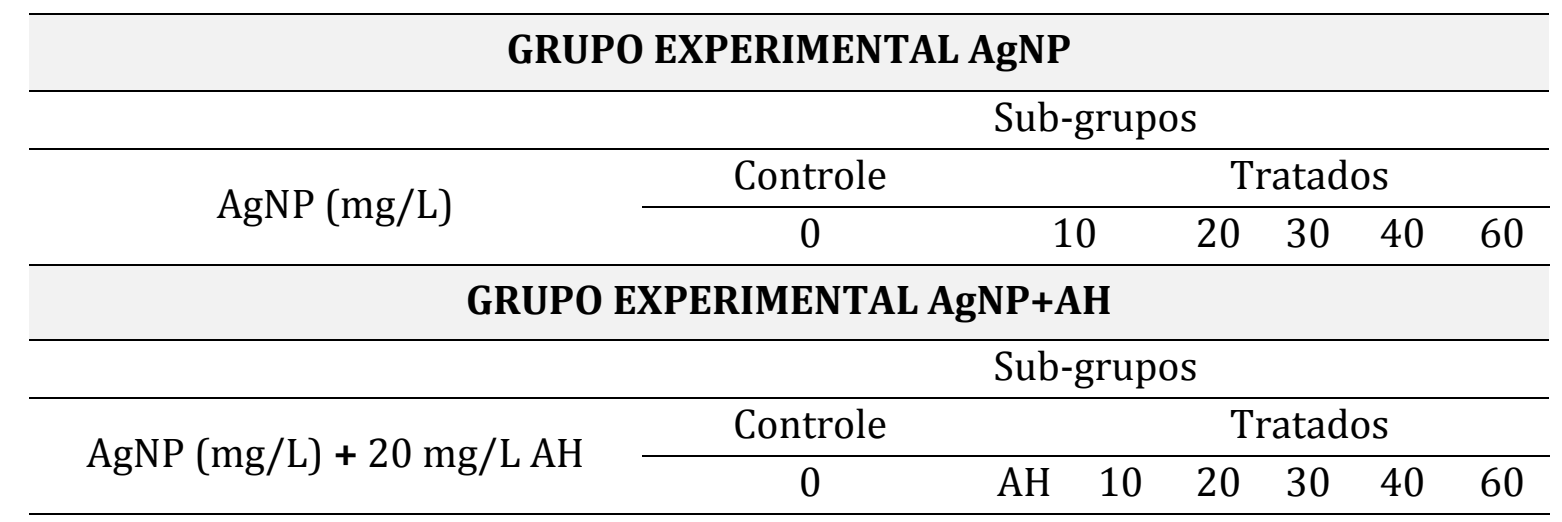

Nos sub-grupos controle (0) foi utilizada apenas água do sistema de manutenção e o sub-grupo AH foi tratado apenas com $20 \mathrm{mg} / \mathrm{L}$ de $\mathrm{AH}$.

\subsubsection{2. $\quad$ Avaliação da Toxicidade em Zebrafish Adultos}

A avaliação da toxicidade aguda em peixes adultos foi baseada na diretriz "Fish, Acute Toxicity Test” da OECD 203 (1992), a fim de determinar a concentração letal média (CL50) das AgNP, com e sem a presença de AH. Peixes com seis meses de idade foram distribuídos em dois grandes grupos, sendo um grupo apenas com nanopartículas de prata e o segundo grupo com nanopartículas de prata na presença de ácido húmico (20 mg/L), como descrito na Tabela 4. Cada sub-grupo foi composto por 7 animais, 
respeitando-se o limite de $1 \mathrm{~g}$ peixe/1 litro de água. A exposição ocorreu por 96 horas em meio estático sob aeração constante.

Após 24, 48, 72 e 96 horas da exposição, os peixes foram observados quanto à ocorrência de alterações clínicas e comportamentais, como perda do equilíbrio, natação superficial, errática e/ou circular, produção de muco branquial, alterações respiratórias, mudanças na cor da pele, morbidade e mortalidade. Ao finalizar a exposição, todos os peixes foram eutanasiados pela secção da medula, seguido de mielotomia. Imediatamente após esse procedimento, nos peixes pertencentes aos sub-grupos 10, 20 e $30 \mathrm{mg} / \mathrm{L}$ de AgNP (com e sem a presença de AH), peixes do sub-grupo controle (apenas com água do sistema), e peixes tratados apenas com $20 \mathrm{mg} / \mathrm{L}$ de $\mathrm{AH}$ foi realizada a coleta sanguínea para realização do teste do cometa, micronúcleo e anormalidades nucleares. Adicionalmente, as brânquias, o fígado e o intestino desses peixes foram coletados para posterior avaliação histopatológica.

\subsubsection{Parâmetros Físico-Químicos da Água do Sistema Contendo Nanopartículas de Prata com e sem a Presença de Ácido Húmico}

Os parâmetros físico-químicos da água do sistema como: temperatura, pH (pHmetro), condutividade (PHTEK CD203), nitritos, amônia e dureza foram avaliados às 96 horas após o preparo das águas contendo AgNP (0;10;20;30; 40 e 60 mg/L AgNP), com ou sem a presença de ácido húmico $(20 \mathrm{mg} / \mathrm{L})$; água contendo apenas $\mathrm{AH}$ (20 $\mathrm{mg} / \mathrm{L})$, e água sem a presença dos materiais teste (AgNP, AgNP+AH e AH). Os parâmetros físico-químicos foram medidos utilizando os kits comerciais de Labcon®.

\subsubsection{Genotoxicidade e Mutagenicidade em Peixes Adultos}

Após realizada a coleta sanguínea com auxílio de pipeta heparinizada, o sangue foi armazenado em microtubos contendo $500 \mu \mathrm{L}$ de soro fetal bovino (SFB). $40 \mu \mathrm{L}$ da mistura (SBF-sangue) foram utilizados para realizar o teste do cometa (KOSMEHL et al., 2008; CÁCERES-VÉLEZ et al., 2016) e $50 \mu \mathrm{L}$ foram utilizados para realizar o esfregaço em lâminas histológicas para o teste do micronúcleo (TSANGARIS et al., 2011; CÁCERESVÉLEZ et al., 2016) e o teste de anormalidades nucleares (CARRASCO et al., 1990; 
CÁCERES-VÉLEZ et al., 2016).

\subsection{Teste do Cometa}

Para realização do teste do cometa, os procedimentos foram realizados de acordo com o protocolo descrito por Kosmehl e colaboradores (2008). Assim, $40 \mu \mathrm{L}$ da solução SBF-sangue foram misturados cuidadosamente com $120 \mu \mathrm{L}$ de agarose "low melting point agarose" (LMP 7\%), previamente fundida e mantida em banho-maria a $37^{\circ} \mathrm{C}$, e aplicadas em lâminas previamente forradas com agarose normal (1,5 \%). Posteriormente, as lâminas foram imersas na solução de lise uso (Triton X de Merck, DMSO de Macron ${ }^{\mathrm{TM}}$, e lise estoque, $\mathrm{pH}$ 10) e após duas horas foram retiradas as lâminas da solução de lise e colocadas na cuba de eletroforese, padronizando a posição para que os cometas corram sempre para o mesmo lado. Seguidamente, foi preenchida a cuba com a solução de eletroforese (EDTA 0,2M de Vetec, NaOH 10M de Vetec, pH 13) até cobrir as lâminas. As lâminas descansaram na cuba (dentro da geladeira) por 20 minutos e a fonte de eletroforese foi regulada para 25 Volts e $300 \mathrm{~mA}$ (com tampão, se necessário) para realizar a eletroforese (20 minutos). Logo após, as lâminas foram imersas em solução tampão de neutralização (Tris de Vetec-Sigma, pH 7,5) por 5 minutos na solução, 5 minutos descansando fora da solução (3 vezes), e deixaram-se secar a temperatura ambiente. Após secagem, as lâminas foram fixadas com etanol absoluto ( 5 minutos) e guardadas na geladeira $\left(4^{\circ} \mathrm{C}\right)$ até o momento da análise. Todas as etapas do teste foram realizadas no escuro e antes de analisar as amostras foi realizado um teste cego escrevendo códigos nas lâminas de modo que, quando for executada a análise não for conhecida a origem das amostras.

As lâminas foram coradas com brometo de etídio $(20 \mu \mathrm{g} / \mathrm{mL})$ no mesmo dia da análise e foram classificadas e analisadas 150 células por individuo, no microscópio de fluorescência (ZEISS Axioskop 2-HAL 100; UnB - Brasília, Brasil). As células observadas foram classificadas de acordo com o tipo de dano $(0,1,2,3$ e 4), os quais correspondem ao tamanho e a proporção do nucleóide-cauda. A classificação baseou-se nos autores Gontijo e colaboradores (2003) e Collins e colaboradores (2008). 


\subsection{Teste de Micronúcleo e Anormalidades Nucleares}

Os testes de micronúcleo e anormalidades nucleares foram realizados de acordo com o protocolo proposto por Fenech e colaboradores (2003) e Barsiene e colaboradores (2006). $50 \mu \mathrm{L}$ da suspensão SBF-sangue foram utilizados para os esfregaços sanguíneos, sendo realizados esfregaços em duas lâminas por individuo. Posteriormente, as lâminas foram secas à temperatura ambiente, fixadas com metanol absoluto (10 minutos), coradas com Giemsa (20 \% v/v) e analisadas no microscópio de luz (ZEISS Axioskop 2-HAL 100) em lente objetiva de 100x. Três mil células foram contadas e analisadas por individuo (realizando previamente o teste cego), cujas características, propostas por Fenech (2003), foram adotadas para a identificação dos micronúcleos (Figura 13).

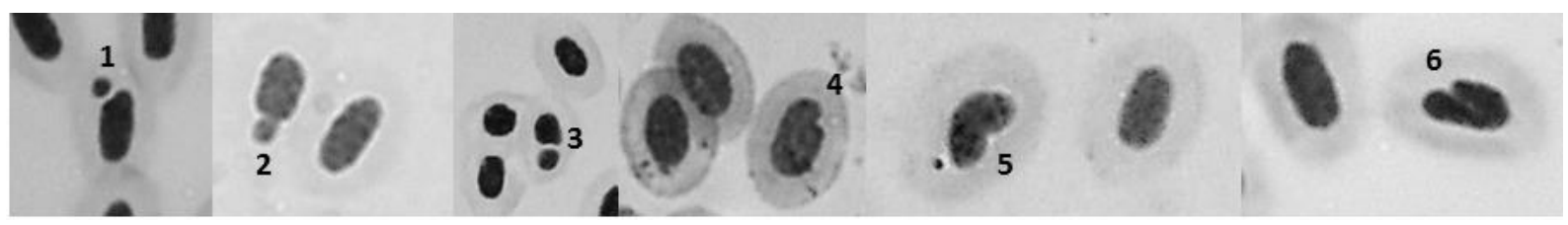

Figura 13. Fotografias de micronúcleo e diferentes tipos de anormalidades nucleares em eritrócitos de sangue periférico de Danio rerio. (1) Micronúcleo, (2) broto, (3) célula binucleada, (4) "blebbed”, (5) “lobed" e (6) "notched”. Tomado de Cáceres-Vélez (2013).

\subsubsection{5. $\quad$ Avaliação Histopatológica}

As brânquias, o fígado e o intestino foram coletados e processados para análise de microscopia de luz (corados com Hematoxilina-Eosina). Os órgãos coletados foram fixados com fixador Davidson (glicerina de Cromoline®, formaldeído 100\%, etanol 100\%, ácido acético glacial de Vetec-Sigma e água destilada) durante 12 horas na geladeira; posteriormente, foi realizada a desidratação com álcool em concentrações crescentes, seguido de diafanização em xilol e inclusão em parafina. As amostras foram cortadas no micrótomo (LEICA RM2235), coradas com H-E e analisadas no microscópio óptico (ZEISS Axioskop 2-HAL 100; UnB - Brasília, Brasil).

A avaliação histológica e a classificação das alterações foram utilizadas de acordo ao proposto por Cáceres-Vélez e colaboradores (2016). Assim, as alterações foram classificadas de acordo com seu estadiamento (Tabela 5) e o fator de importância (FI) 
em relação ao impacto sobre a saúde dos peixes. Cada alteração foi classificada de acordo ao FI ou grau da lesão, atribuindo valores de 0 a 3. Deste modo, o grau 0 representa os órgão sem alterações; o grau 1, alterações leves, facilmente reversíveis; o grau 2, alterações moderadas que podem ser reversíveis ou irreversíveis; e o grau 3, alterações graves que geralmente são irreversíveis e a sua persistência e progressão pode levar a uma perda parcial ou total da função do órgão.

Cada órgão foi avaliado separadamente, calculando três índices (1, 2 e 3). 0 primeiro índice $\left(\mathrm{E}_{\mathrm{A}}\right)$ foi calculado separadamente para cada estágio (I, II e III) apresentado em cada peixe. 0 segundo índice ( $\mathrm{T}_{\mathrm{P}}$-dano total por peixe) foi a somatória dos resultados de cada $\left.\mathrm{E}_{\mathrm{A}(\mathrm{I}, \mathrm{II}, \mathrm{e}} \mathrm{III}\right)$. E o terceiro índice ( $\mathrm{T}_{\mathrm{G}}$-dano total por grupo) foi a soma dos $\mathrm{T}_{\mathrm{P}}$ dividida pelo número de indivíduos.

$\mathrm{E}_{\mathrm{A}}=\sum(\mathrm{Y} \times \mathrm{FI})$

$T_{P}=E_{I}+E_{I I}+E_{I I I}$

$\mathrm{T}_{\mathrm{G}}=\sum \mathrm{T}_{\mathrm{P}} / \mathrm{n}$

Onde,

E: Estágio

A: estágio I, II ou III

Y: ausência de alteração (0) ou presença (1),

FI: fator de importância,

n: número total de indivíduos analisados por grupo (7)

$\mathrm{T}_{\mathrm{P}}$ : índice patológico total do peixe,

$\mathrm{T}_{\mathrm{G}}$ : índice patológico total do grupo experimental. 
Tabela 5. Alterações histológicas em brânquias, fígado e intestino, classificadas segundo o estadiamento. Tomada de Cáceres-Vélez (2013).

\begin{tabular}{cc}
\hline ESTÁDIO (E) & ALTERAÇõES HISTOLÓGICAS DAS BRÂNQUIAS \\
\hline I & $\begin{array}{c}\text { Hipertrofia* e hiperplasia* epitélio lamelar } \\
\text { Congestão sanguínea }\end{array}$ \\
& Descolamento do epitélio lamelar \\
Fusão lamelar \\
Hiperplasia da cartilagem \\
Infiltração de leucócitos* \\
II & Hemorragia e ruptura do epitélio lamelar \\
& Hipertrofia e hiperplasia de células mucosas \\
& Edema* \\
Hipertrofia e hiperplasia de células de cloreto & Aneurisma lamelar \\
& Vacuolização* \\
& Necrose (picnose, cariólise e cariorréxis)* \\
& Degeneração celular*
\end{tabular}

*Alterações para o fígado e o intestino.

4.9.3.6. $\quad$ Avaliação da Acumulação/Biodistribuição das Nanopartículas de Prata em Zebrafish Adultos

Baseado nos dados obtidos na determinação da concentração letal média (CL50-96h), peixes com aproximadamente 6 meses de idade $(2 \pm 1 \mathrm{~cm})$ foram alocados em sete grupos experimentais, cada um deles com 5 peixes. Os peixes foram tratados com concentrações crescentes de nanopartículas de prata em meio estático e aeração constante, avaliados às $96 \mathrm{~h}$ após exposição. Os subgrupos de exposição foram constituídos por: dois subgrupos expostos só a AgNP (10 e 20 mg/L AgNP), três subgrupos expostos a AgNP (10, 20 e $30 \mathrm{mg} / \mathrm{L}$ AgNP) na presença de $\mathrm{AH}(20 \mathrm{mg} / \mathrm{L} \mathrm{AH})$ e mais dois subgrupos controle (0 mg/L AgNP, $20 \mathrm{mg} / \mathrm{L} \mathrm{AH}$ ). Durante a exposição, os animais foram observados quanto à ocorrência de morbidade e alterações clínicas e/ou comportamentais. As populações nos aquários não excederam a concentração máxima 
de 1,0 g peixe por litro de água.

Ao final da exposição os peixes foram eutanasiados pela secção da medula, seguido de mielotomia, e posteriormente medidos (peso e comprimento). Baseados nos protocolos propostos por Zimmermann e colaboradores (2001), Ashoka e colaboradores (2009), Krystek (2012) e Osborne e colaboradores (2015), as brânquias, o músculo (parte caudal), o intestino, o fígado e o rim foram coletados, colocados em microtubos e estocados a $-20^{\circ} \mathrm{C}$. Após, as diferentes amostras foram liofilizadas e pesadas a fim de conhecer o peso seco. Para a digestão ácida das amostras foi utilizado o ácido nítrico $\left(\mathrm{HNO}_{3} \mathrm{70} \%\right)$, deixando-se reagir durante $48 \mathrm{~h}$ à temperatura ambiente. Após, foram realizadas diluições para obter amostras com um volume final de $10 \mathrm{~mL}$ e uma concentração de $\mathrm{HNO}_{3}$ 2\%. Finalmente, a análise quantitativa da prata foi realizada por ICP-MS (iCAP ${ }^{\mathrm{TM}}$ Q ICP-MS Thermo Scientific ${ }^{\mathrm{TM}}$; CICBiomaGUNE - San Sebastián, Espanha). Cada amostra foi medida em triplicata.

\subsection{ANÁLISE ESTATÍSTICA}

Os dados quantitativos foram avaliados por meio de estatística paramétrica ou não paramétrica, de acordo com a distribuição de normalidade, utilizando o teste Kolmogorov-Smirnov. Para os dados paramétricos, foi realizada a Análise de Variância (ANOVA) seguido do teste Tukey-Kramer; os dados não paramétricos foram analisados com o teste de Kruskal-Wallis seguido do Teste Dunn (comparações múltiplas). As análises dos dados quantitativos foram realizadas utilizando o Teste Exato de Fisher e, para a determinação da CL50, foi utilizado o Teste Probit (SPSS). 0 programa estatístico utilizado foi GraphPad Instat 3.02, cujo nível de significância foi estabelecido em 5\%. 
5.

\section{$\mathbf{R}_{\text {rsurtados }}$}

\section{1. ÁGUA UTILIZADA PARA OS DIFERENTES EXPERIMENTOS}

Na tabela a seguir mostram-se os dados obtidos (Tabela 6), observando que a água REC possui maior quantidade de magnésio, potássio cálcio e prata do que a água MQ e SIST. No entanto, a quantidade de sódio foi maior na água SIST. É importante destacar que foram detectados traços de prata em todos os tipos de água utilizada nos experimentos, sendo estes $\leq 0,04 \mu \mathrm{g} / \mathrm{L}$.

Tabela 6. Caracterização da água MQ, REC e SIST por ICP-MS.

\begin{tabular}{cccccc}
\hline AMOSTRA & Ag ( $\boldsymbol{\mu g} / \mathbf{L})$ & $\mathbf{C a}(\mathbf{m g} / \mathbf{L})$ & $\mathbf{K}(\mathbf{m g} / \mathbf{L})$ & $\mathbf{M g}(\mathbf{m g} / \mathbf{L})$ & $\mathrm{Na}(\mathbf{m g} / \mathbf{L})$ \\
\hline MQ & $<0,01$ & $<0,05$ & $<0,05$ & $<0,05$ & $<0,05$ \\
REC & $<0,01$ & 104,00 & 3,17 & 12,90 & 19,00 \\
SIST & 0,04 & 3,99 & 3,06 & 7,87 & 86,40 \\
\hline
\end{tabular}

\subsection{CARACTERIZAÇÃO DAS NANOPARTÍCULAS DE PRATA E DO ÁCIDO HÚMICO}

As análises por MET permitiram verificar o estado de agregação, o formato e o tamanho das AgNP (Figura 14). Observamos nanopartículas de formato variável e irregular, cujo diâmetro médio foi de $26 \pm 16 \mathrm{~nm}$ (Figura 14B). Também observamos que as AgNP permaneceram agregadas, mesmo após a sonicação, como representado na Figura 14A. 

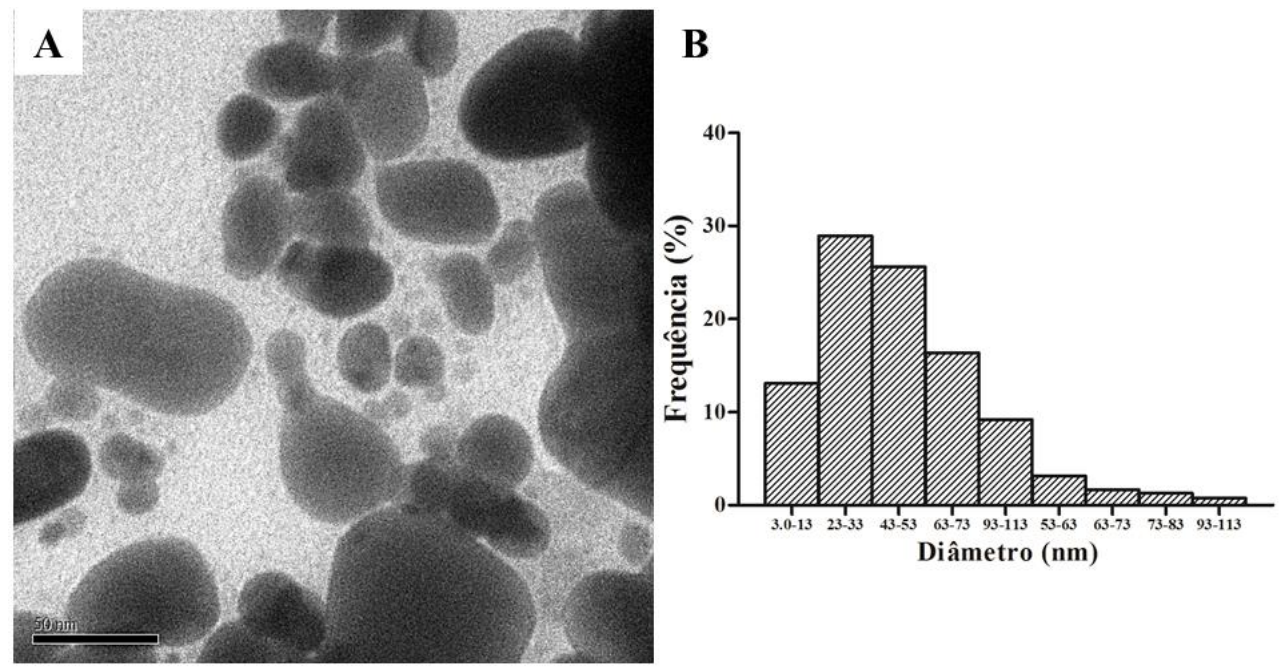

Figura 14. Caracterização das AgNP por MET. (A) Micrografia eletrônica de transmissão apresentando nanopartículas com formatos variáveis e irregulares com diâmetro médio de $26 \pm 16 \mathrm{~nm}$. (B) Histograma com a distribuição de frequências dos tamanhos das AgNP. A barra corresponde a $50 \mathrm{~nm}$.

A Figura 15 apresenta o difratograma das AgNP, que correspondem ao padrão apresentado pela prata metálica $\left(\mathrm{Ag}^{0}\right)$ na literatura. Também podemos observar a ausência de espalhamento difuso no difratograma, um indicativo da ausência ou baixa concentração de material amorfo na amostra e ausência de pico relacionado ao óxido de prata. Com esta metodologia também foi possível calcular o diâmetro médio dos cristalitos das AgNP que foi de $20 \mathrm{~nm}$, menor ao tamanho médio observado por MET $(26 \pm 16 \mathrm{~nm})$.

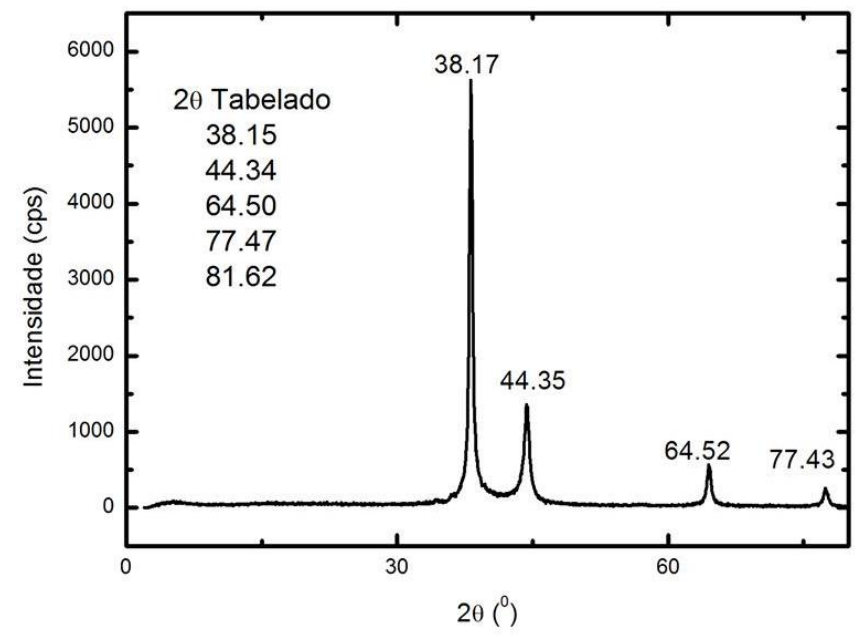

Figura 15. Difratograma de raios $X$ das nanopartículas de prata em pó. Os dados experimentais obtidos ( $2 \theta$ tabelado) correspondem ao padrão apresentado pela prata metálica $\left(\mathrm{Ag}^{0}\right)$ na literatura. 0 diâmetro médio das AgNP calculado foi de $20 \mathrm{~nm}$. 
O espectro 3d da amostra de AgNP analisada por XPS está representado na Figura 16. Destaca-se a apresentação de alta qualidade do espectro, onde se observa que em torno de $368,4 \mathrm{eV}$ está posicionado o pico $3 \mathrm{~d}_{5 / 2}$, indicando que as AgNP correspondem a prata metálica $\left(\mathrm{Ag}^{0}\right)$, de acordo com o estabelecido na literatura (MOULDER et al., 1995).

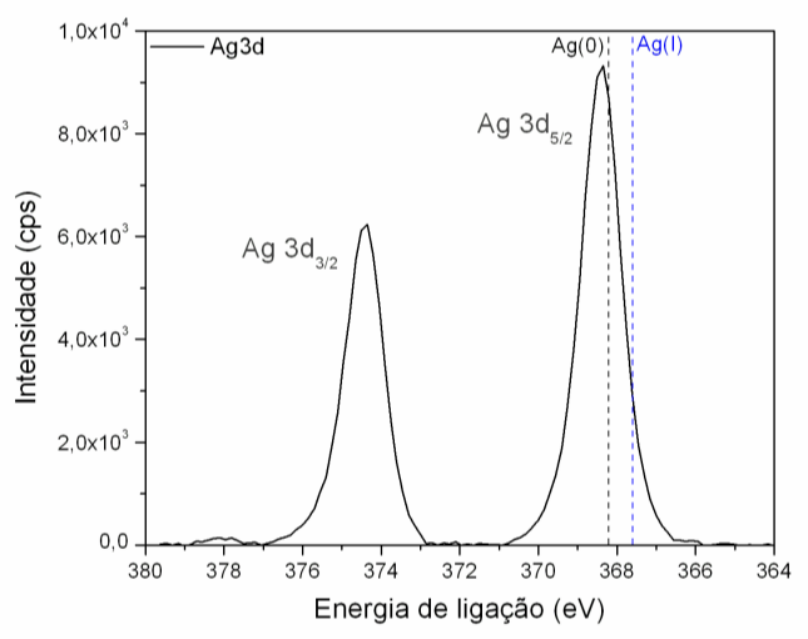

Figura 16. Espectro XPS das AgNP. Picos referentes a energia de ligação encontradas, comparadas com os valores teóricos para as regiões $3 \mathrm{~d}$ da $\mathrm{Ag}(0)$ e da $\mathrm{Ag}(\mathrm{I})$, indicando que as AgNP correspondem a Ag (0).

A determinação do estado químico da amostra (Figura 17) foi realizada utilizando o parâmetro Auger modificado, $\alpha$. Definido como a diferença entre a energia cinética do fotoelétron mais intenso ( $\mathrm{Ag} 3 \mathrm{~d}_{5 / 2}$ ) e o pico Auger (Ag $\mathrm{M}_{5} \mathrm{VV}$ ) de maior energia, mais a energia da fonte de excitação (1253.6 eV para Mg). 0 parâmetro Auger modificado, $\alpha$, calculado para a amostra de AgNP foi de $726.1 \mathrm{eV}$, o qual está de acordo com os valores estabelecidos na literatura (MOULDER et al., 1995) para prata metálica $\left(\mathrm{Ag}^{0}\right)$. Assim, tanto os dados obtidos por DRX (Figura 15) e por XPS (Figuras 16 e 17) corroboram que as AgNP correspondem a prata metálica. 


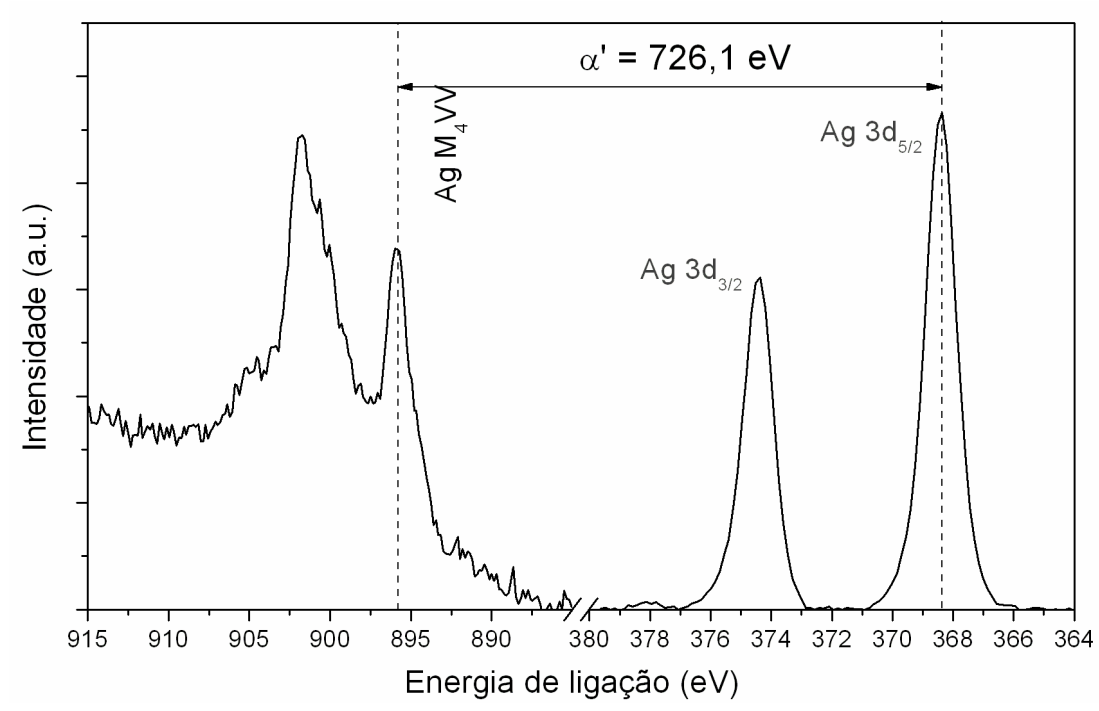

Figura 17. Espectro Auger das AgNP. 0 parâmetro Auger calculado para a amostra de AgNP foi de $726.1 \mathrm{eV}$, indicando que as AgNP correspondem a Ag (0).

As análises do ácido húmico realizadas por XPS permitiram conhecer a sua composição química e a energia de ligação, através de escaneamentos de alta resolução, para o carbono e o oxigênio. No espectro XPS, mostrado na Figura 18, podem ser observados três picos típicos para os orbitais do carbono 1s (C1s), do oxigênio 1s (01s) e do sódio 1s (Na1s), com energias de ligação em 285 eV, 533 eV e 1070 eV, respectivamente, indicando a que a composição química do $\mathrm{AH}$ é dada principalmente pela presença dos elementos carbono, oxigênio e sódio. Adicionalmente, a Figura 19A mostra o espectro com os picos ajustados e associados às ligações $\mathrm{C}-\mathrm{C} / \mathrm{C}$-H com outros componentes associados às ligações $\mathrm{C}-\mathrm{O}, \mathrm{C}=\mathrm{O}$ e $\mathrm{CO}_{2}$. No espectro são mostradas as posições esperadas para as ligações do C-C e C-H designadas a 285,0 eV; ligações CO em torno de 286,5 eV; ligações $\mathrm{C}=\mathrm{O}$ e $0=\mathrm{C}-\mathrm{OH}$ ao redor de 288,5 eV e ligações $\mathrm{CO}_{2}$ em torno de 290,5 eV. O espectro 01s do AH (Figura 19B) mostra as posições esperadas para as ligações C=0 e C-O em torno de 531,6 e 533,1 eV; respectivamente. 


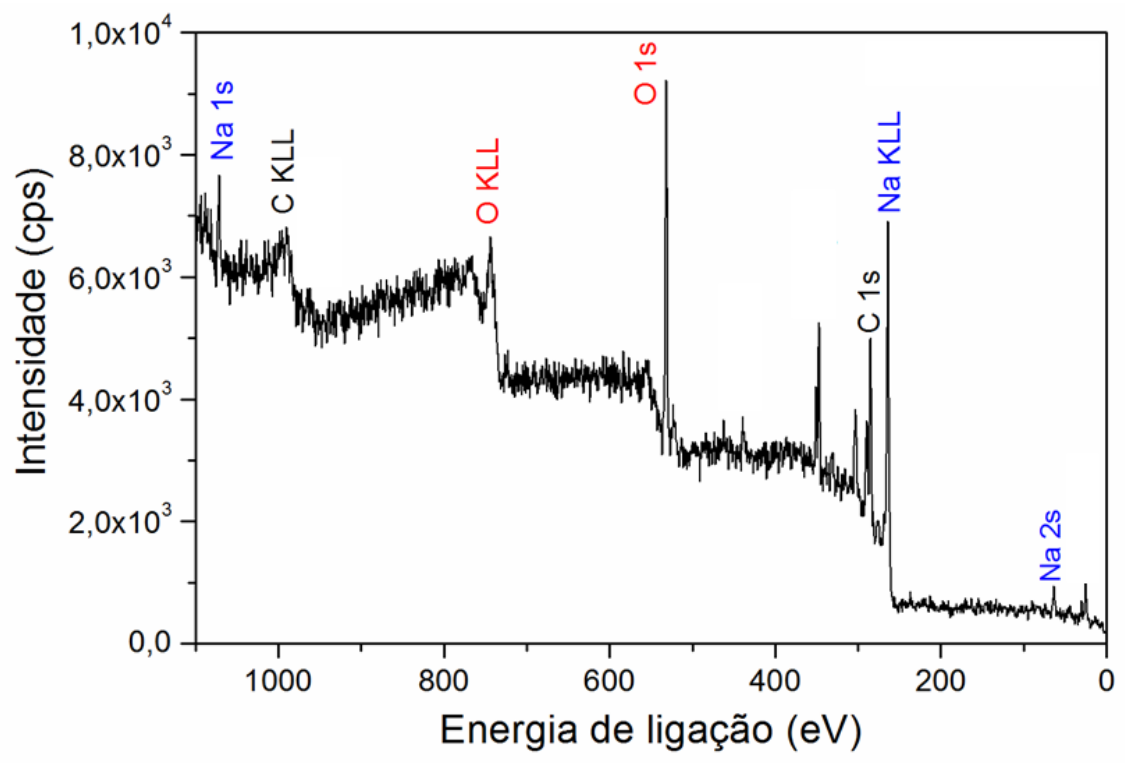

Figura 18. Caracterização do ácido húmico em pó por XPS. No espectro estão indicados os picos correspondentes para os diferentes elementos (carbono, oxigênio e sódio) encontrados no AH.
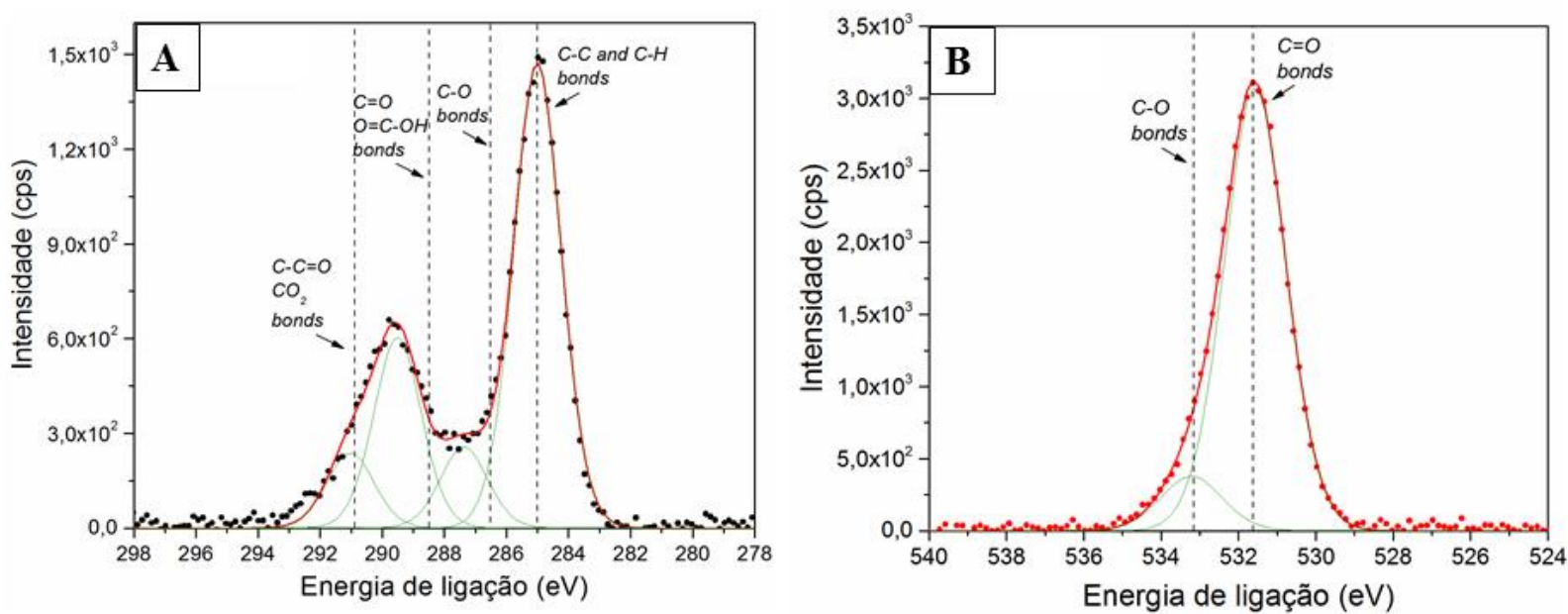

Figura 19. Caracterização do ácido húmico em pó por XPS. As regiões dos espectros C1s e 01s obtidos para o AH estão representados nas figuras A e B, respectivamente. Nos espectros estão indicados (setas) os picos correspondentes para as diferentes ligações encontradas para o carbono e o oxigênio.

Na Figura 20 pode ser observada a estrutura típica do AH obtida por espectroscopia FTIR. O espectro FTIR obtido (Figura 20A) apresenta picos localizados a $3400 \mathrm{~cm}^{-1}$ pertencente ao stretching do grupamento $0-\mathrm{H}, 2928 \mathrm{~cm}^{-1}$ atribuído ao stretching do $\mathrm{C}-\mathrm{H}$ alifático e ao stretching do $\mathrm{C}-\mathrm{H}$ dos grupos metilo. $\mathrm{O}$ pico em torno de 
$1500 \mathrm{~cm}^{-1}$ corresponde ao stretching do $\mathrm{C}=\mathrm{C}$ aromático e os picos em 1581 e $1402 \mathrm{~cm}^{-1}$ correspondem ao stretching assimétrico e simétrico, respectivamente, do grupamento carboxila. A região em torno de 1300 a $1000 \mathrm{~cm}^{-1}$ corresponde ao stretching do C-OH alifático e os números de onda entre 900 a $700 \mathrm{~cm}^{-1}$ oferece informação sobre os planos vibracionais do $\mathrm{C}-\mathrm{H}$ aromático, ligações do benzeno e do alquilbenzeno presentes na molécula de $\mathrm{AH}$. As posições dos picos, mencionados anteriormente, estão listados na Figura 20B.

Os espectros do AH em água MQ (Figura 21) foram obtidos por espectroscopia na região do ultravioleta/visível (UV-VIS). Nos espectros é possível observar dois picos, um deles em $270 \mathrm{~nm}$ e outro perto de $400 \mathrm{~nm}$, sendo o primeiro um pico discreto. Adicionalmente, os espectros mostram decréscimos nas intensidades da absorção ao aumentar o comprimento de onda. Isto pode estar relacionado com o fato de que a matéria orgânica possui cromóforos, como estruturas aromáticas (quinonas e cetonas), que absorvem em toda a região analisada (200-600 nm).

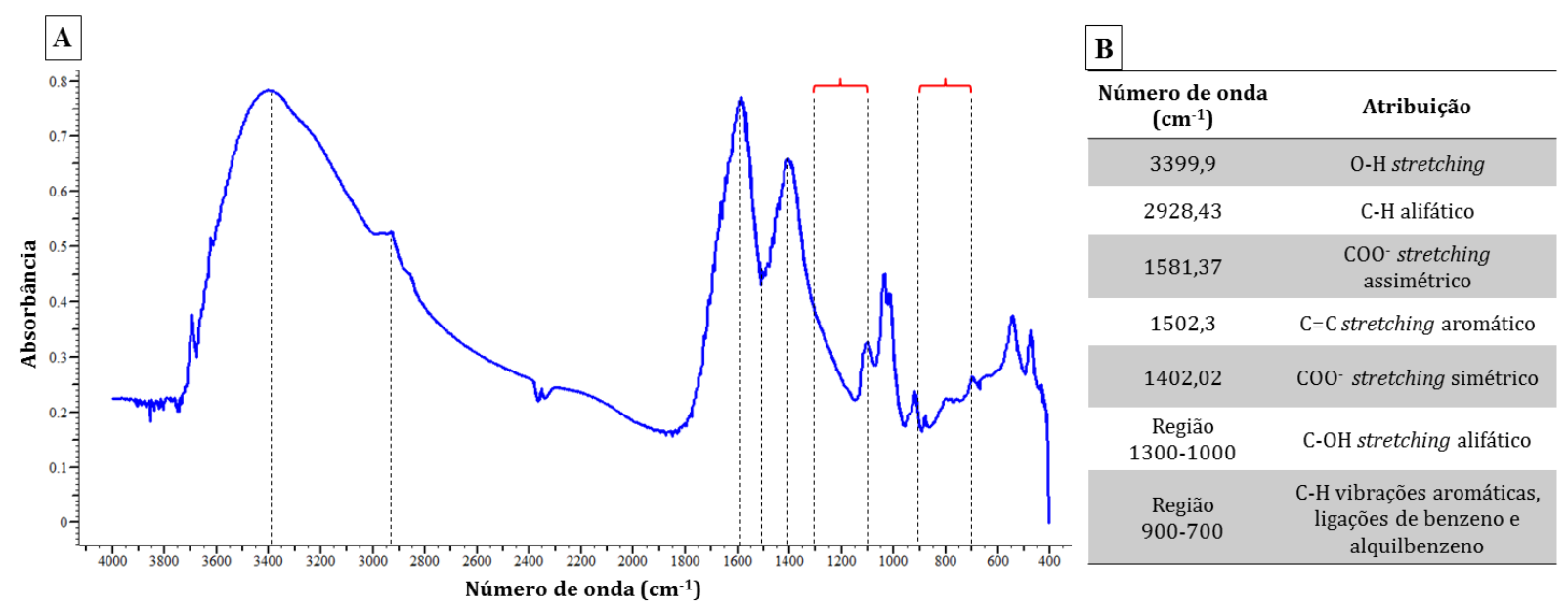

Figura 20. Caracterização do ácido húmico em pó por FTIR. (A) Espectro FTIR do AH cujos valores indicados por setas e chaves estão representados na tabela (B). 


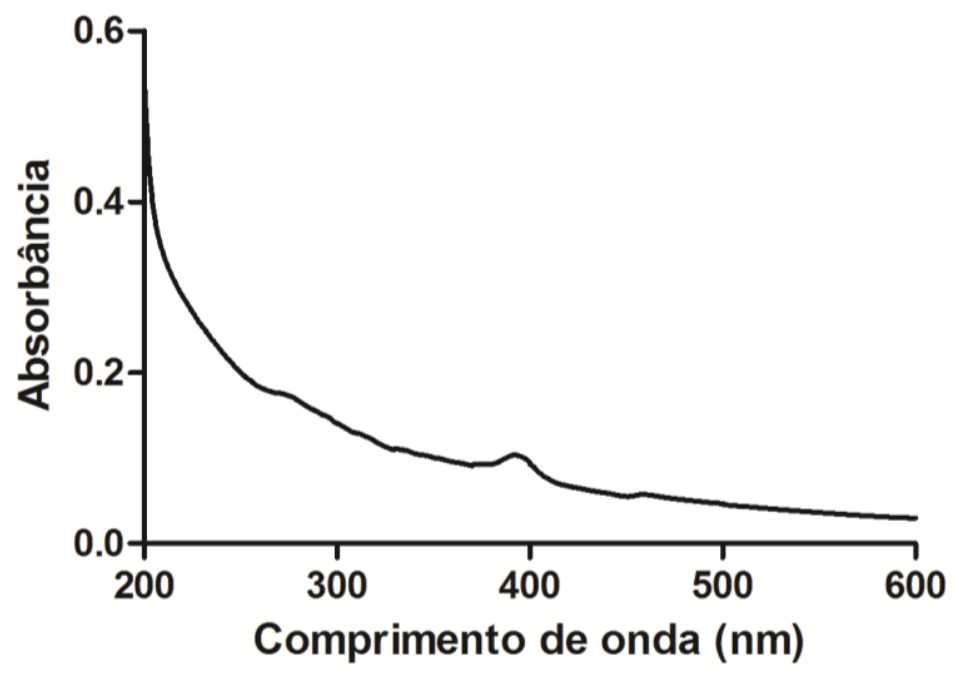

Figura 21. Espectros UV/VIS do AH (20 mg/L) suspenso em água ultrapura (MQ). Os espectros foram obtidos na faixa de 200-600 nm. Observam-se picos característicos do AH em $270 \mathrm{~nm}$ e $392 \mathrm{~nm}$.

\subsection{ESTABILIDADE DAS NANOPARTÍCULAS DE PRATA EM DIFERENTES MEIOS AQUOSOS}

Os resultados obtidos estão representados na Figura 22. A estabilidade das suspensões de nanopartículas de prata, medidas durante um período de 24 horas, mostraram alterações quando foi adicionado o $\mathrm{NaCl}$ (Figura 22), sendo que, quanto maior a concentração de $\mathrm{NaCl}$ menor é a proporção $\mathrm{A} / \mathrm{A}_{0}$ (A: Absorbância no tempo final, $\mathrm{A}_{0}$ : Absorbância no tempo inicial). Na Figura 22 observamos um declínio nas curvas ao longo do tempo, sendo este mais evidente após 120 minutos. Também notamos uma sobreposição das curvas referentes às amostras de AgNP em suspensão na água do sistema e na água MQ, indicando comportamentos similares das nanopartículas nesses sistemas aquosos. Na Figura 22 pode-se observar que partir do tempo de 120 minutos o declínio nas curvas sobrepostas é mais perceptível, indicando que até 120 minutos as suspensões de AgNP são mais estáveis ao apresentar valores de $\mathrm{A} / \mathrm{A}_{0}$ (absorbância final/absorbância inicial em cada tempo) próximos a um. 


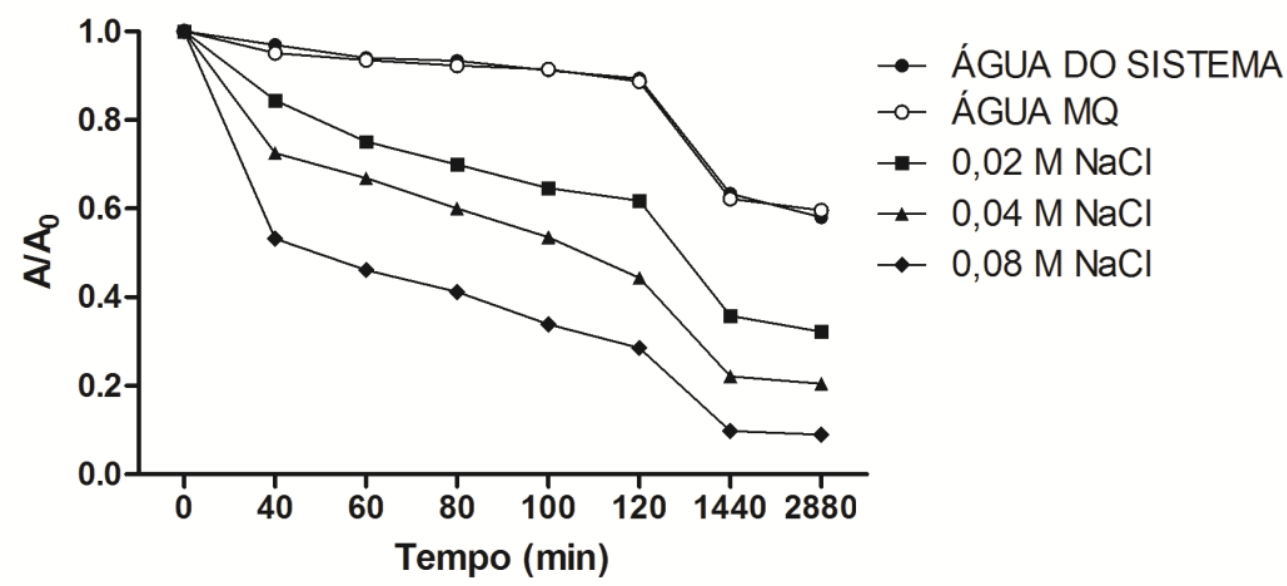

Figura 22. Análise das AgNP (100 mg/L) na presença de diferentes concentrações de $\mathrm{NaCl}(0,02$; $0,04$ e $0,08 \mathrm{M})$ e pH neutro $(7,0 \pm 0,5)$. Medidas da absorbância no tempo inicial e final $(\mathrm{A} / \mathrm{A} 0)$ de cada amostra, ao longo de 48 horas (2880 min), correlacionado com a sedimentação das AgNP em função da força iônica. Todas as amostras foram dispersas em água do sistema. 1440 min=24 horas, $2880 \mathrm{~min}=48$ horas. Os dados representam a Média \pm Desvio Padrão.

O comportamento descrito anteriormente (Figura 22) pode ser também observado na Figura 23A, onde as AgNP apresentaram maior agregação e incremento no tamanho dos agregados ao longo do tempo nos sistemas aquosos que continham $\mathrm{NaCl}$ em concentrações de 0,04 e 0,08M. No entanto, as AgNP em água com $\mathrm{NaCl}$ 0,02 M, na água MQ e SIST, apresentaram comportamentos similares quanto à agregação e tamanho dos agregados ao longo do tempo. Deste modo, as AgNP se agregaram com maior facilidade em sistemas aquosos com alta concentração de sal.

Na Figura 23B estão representadas as medições do potencial zeta das diferentes amostras. Os dados mostram que o potencial zeta diminui com o aumento da força iônica, cujo comportamento das nanopartículas é bastante repulsivo em baixa força iônica. Também observamos um declínio nos valores do potencial zeta a partir dos 120 minutos para as AgNP em suspensão nos diferentes meios aquosos, exceto nas suspensões com água do sistema, que apresentaram valores constantes do potencial zeta ao longo do tempo. 

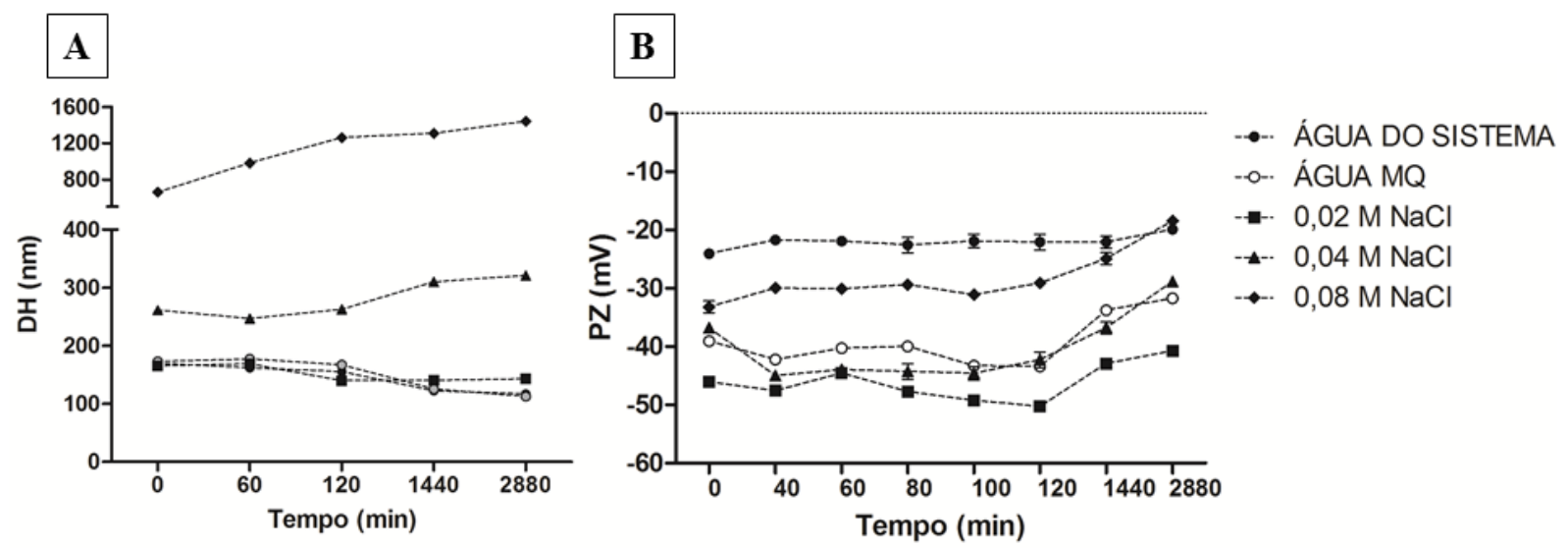

Figura 23. Diâmetro hidrodinâmico e potencial zeta das AgNP (100 mg/L) para diferentes concentrações de $\mathrm{NaCl}(0,02 ; 0,04$ e $0,08 \mathrm{M})$ e pH neutro $(7,0 \pm 0,5)$. (A) Medidas do diâmetro hidrodinâmico de cada amostra, ao longo de 48 horas (2880 min), em função da força iônica. (B) Medições do potencial zeta das AgNP em função da força iônica. Todas as amostras foram dispersas em água do sistema. $1440 \mathrm{~min}=24$ horas, $2880 \mathrm{~min}=48$ horas. Os dados representam a Média \pm Desvio Padrão.

Na Figura 24 é possível observar que as AgNP apresentam maior estabilidade quando aumentamos a concentração de AH. Assim, a suspensão mais estável de nanopartículas foi observada na concentração de $100 \mathrm{mg} / \mathrm{L}$ de $\mathrm{AH}$, seguida pela concentração de 50; 25 e 12,5 mg/L de AH. Para todas as amostras (especialmente para as concentrações de 0; 12,5 e $25 \mathrm{mg} / \mathrm{L}$ de AH), após 120 minutos, o decaimento da proporção $\mathrm{A} / \mathrm{A}_{0}$ foi mais evidente, indicando um aumento na taxa de aglomeração e sedimentação das nanopartículas nesse tempo, e consequentemente uma diminuição na estabilidade dos sistemas ao longo do tempo. Por outro lado, o diâmetro hidrodinâmico das amostras (Figura 25A) indica que as AgNP sem a presença de AH apresentaram maior tamanho dos agregados quando comparado com os tamanhos das outras amostras que continham AH. Adicionalmente, essa amostra apresentou um aumento notório no tamanho dos agregados no tempo de 2880 minutos (48 horas), enquanto que as outras amostras apresentaram um decréscimo a partir dos 120 minutos. 


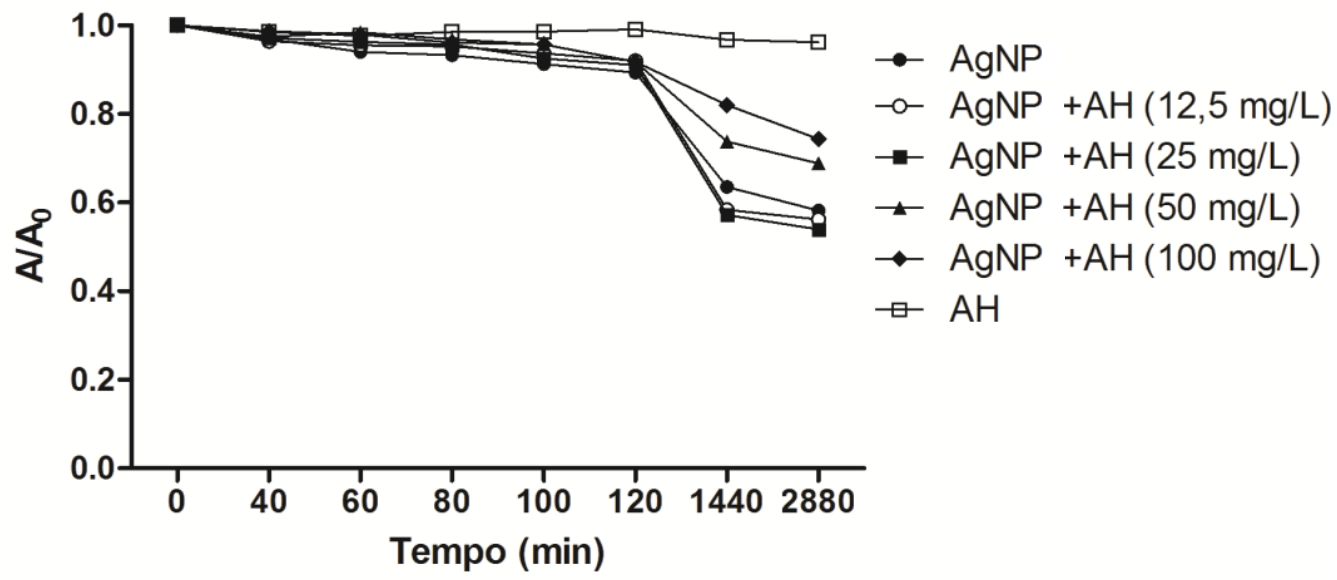

Figura 24. Análise das AgNP (100 mg/L) na presença de diferentes concentrações de AH (12,5; 12; 50 e $100 \mathrm{mg} / \mathrm{L})$ e pH neutro $(7,0 \pm 0,5)$. Medidas da absorbância no tempo inicial e final (A/A0) de cada amostra, ao longo de 48 horas (2880 min), em função da concentração de AH. Todas as amostras foram dispersas em água do sistema. 1440 min=24 horas, 2880 min=48 horas. Os dados representam a Média \pm Desvio Padrão.

O potencial zeta em $\mathrm{pH}$ neutro $(7,5 \pm 0,5)$ das AgNP em concentrações crescentes de AH estão representados na Figura 25B. O aumento da negatividade nos valores do potencial zeta foi observado, especialmente, nas concentrações 50 e $100 \mathrm{mg} / \mathrm{L}$ de $\mathrm{AH}$. Na Figura 25B pode se observar que a amostra de $\mathrm{AH}$ e a amostra que continha as $\mathrm{AgNP}+\mathrm{AH}$ (100 mg/L) apresentaram valores similares no potencial zeta ao longo do tempo, e adicionalmente, para todas as amostras analisadas os valores do potencial zeta apresentaram comportamento similar ao longo do tempo.

Na Figura 26 podem ser observadas as micrografias eletrônicas de transmissão das AgNP na presença de $\mathrm{AH}$ em diferentes concentrações, às 6 e 24 horas após o preparo. As imagens são representativas para cada amostra e podem ser observados diferentes estados de agregação nos diferentes tempos avaliados; encontrando que os agregados de AgNP tornam-se maiores ao longo do tempo e também quando a concentração de AH aumenta. Adicionalmente, pode se observar a possível adsorção do AH (setas) na superfície das AgNP. 

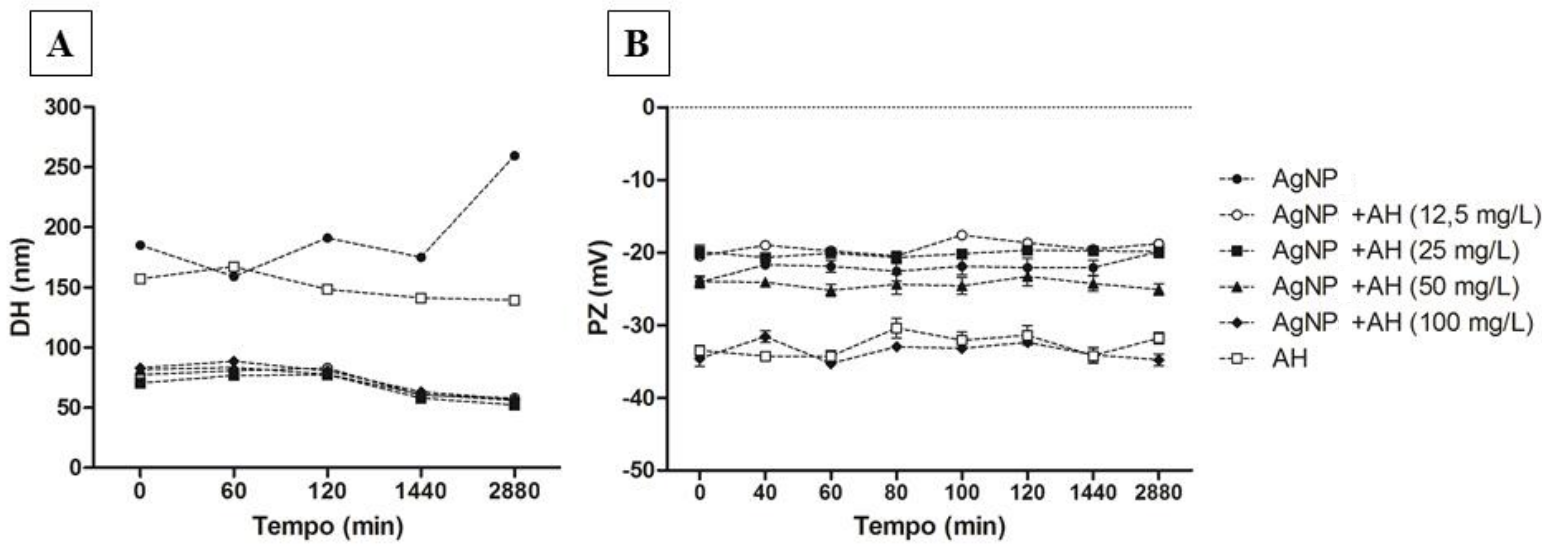

Figura 25. Diâmetro hidrodinâmico e potencial zeta das AgNP (100 mg/L) na presença de diferentes concentrações de $\mathrm{AH}(12,5 ; 12 ; 50$ e $100 \mathrm{mg} / \mathrm{L})$ e pH neutro $(7,0 \pm 0,5)$. (A) Medidas do diâmetro hidrodinâmico de cada amostra, ao longo de 48 horas (2880 min), em função da concentração de AH. (B) Medições do potencial zeta das AgNP em função da concentração do AH. Todas as amostras foram dispersas em água do sistema. 1440 min=24 horas, 2880 min=48 horas. Os dados representam a Média \pm Desvio Padrão.

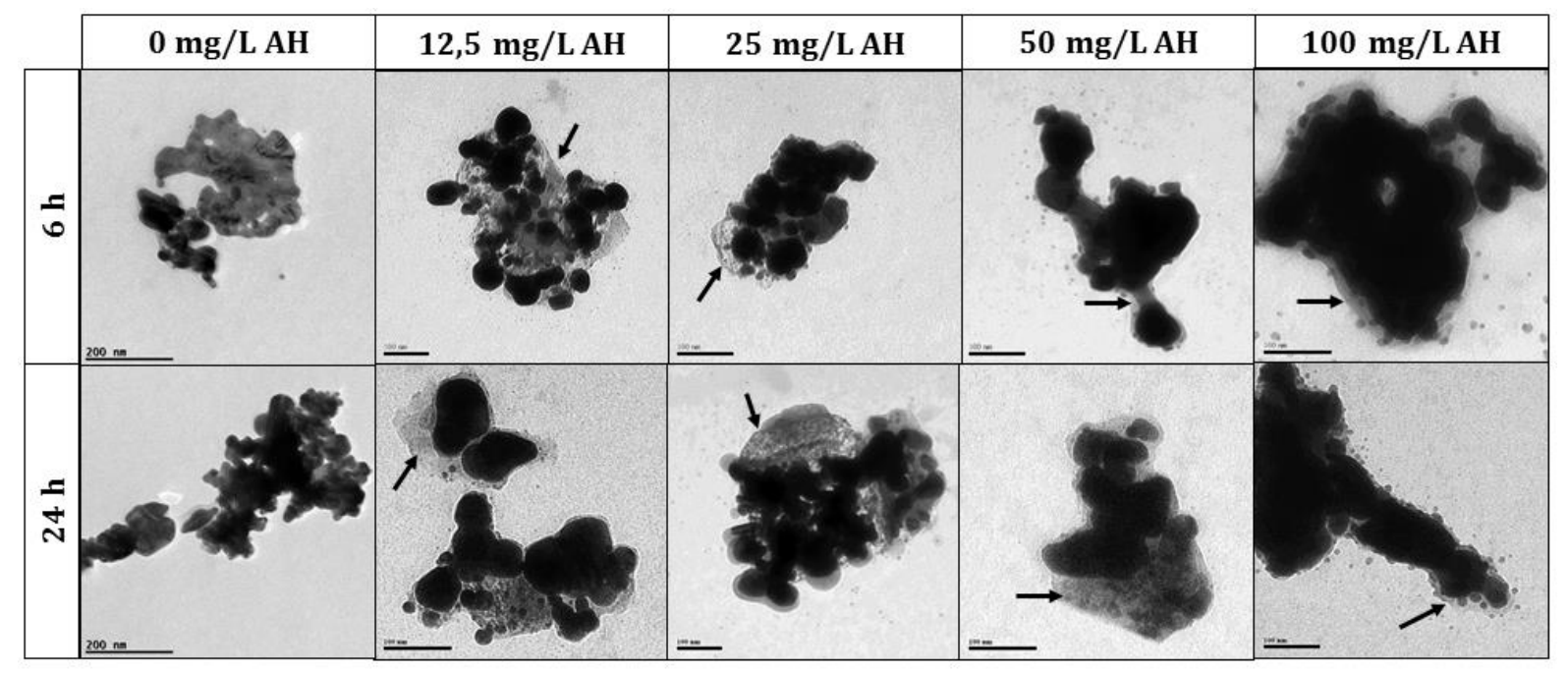

Figura 26. Micrografias eletrônicas de transmissão representativas das AgNP na presença de AH em diferentes concentrações (12,5; 12; 50 e 100 mg/L) às 6 e 24 horas após sonicação. Pode se observar os diferentes estados de agregação das AgNP nas diferentes amostras avaliadas. As setas indicam a possível adsorção do AH (menor elétron-densidade) nas AgNP. As escalas de barras correspondem a $100 \mathrm{~nm}(12,5-100 \mathrm{mg} / \mathrm{L})$ e $200 \mathrm{~nm}(0 \mathrm{mg} / \mathrm{L})$. 
O comportamento das AgNP em água MQ, água SIST e água REC, com e sem a presença de AH, está representado nas Figuras 27, 28 e 29, onde se mostram os valores obtidos no diâmetro hidrodinâmico e potencial zeta dos diferentes sistemas avaliados ao longo de 96 horas. Na Figura 27 pode ser observado que o diâmetro hidrodinâmico das AgNP suspendidas em água REC foi maior do que na água MQ e SIST, sendo que as nanopartículas na água MQ e SIST apresentaram um comportamento mais próximo. Adicionalmente, foi possível se observar que as AgNP em água REC formaram agregados de maior tamanho, com variações no mesmo, ao longo de 96 horas; enquanto que o diâmetro hidrodinâmico das AgNP em água MQ e SIST foi mais estável durante o período avaliado. Deste modo, quando se aumentou a concentração de sais no meio, as AgNP se agregaram com maior facilidade.

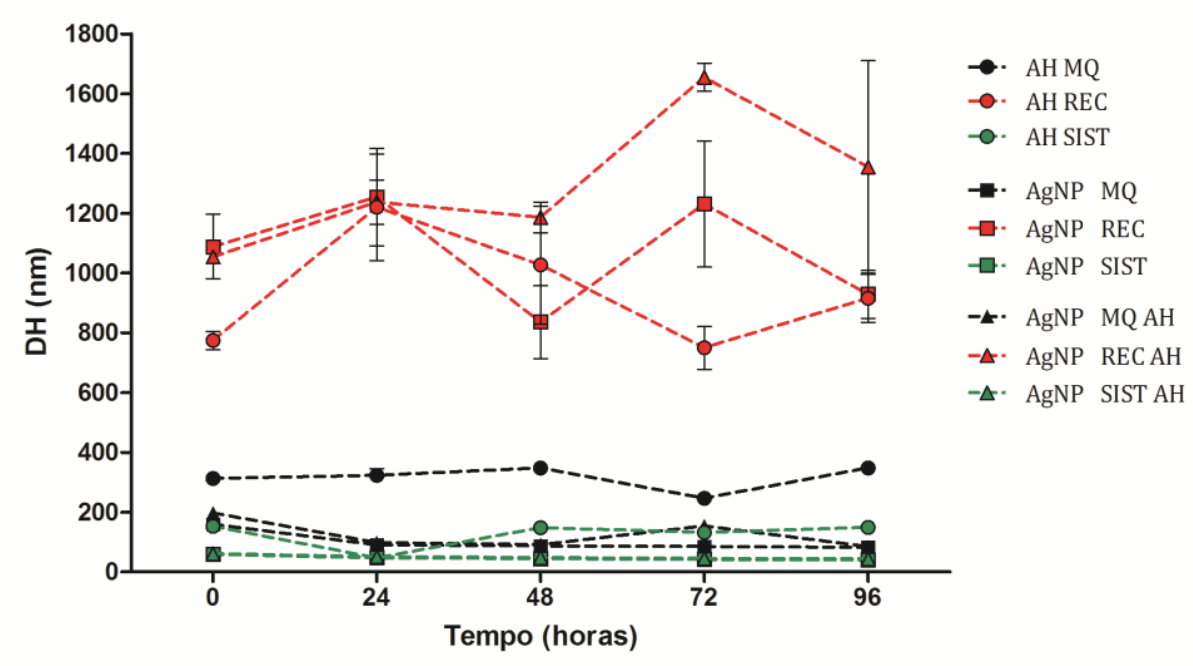

Figura 27. Valores do diâmetro hidrodinâmico das AgNP (30 mg/L) na presença de AH (20 $\mathrm{mg} / \mathrm{L}$ ), em água MQ, REC e SIST. Os dados correspondem às medidas obtidas diariamente, por 96 horas, após sonicação, e estão representados pela Média \pm Desvio Padrão. MQ AH (Ácido húmico em água ultrapura), MQ Ag (água ultrapura contendo AgNP), MQ AH Ag (Ácido húmico em água ultrapura contendo AgNP), REC AH (Ácido húmico em água reconstituída), REC Ag (água reconstituída contendo AgNP), REC AH Ag (Ácido húmico em água reconstituída contendo AgNP), SIST AH (Ácido húmico em água do sistema), SIST Ag (água do sistema contendo AgNP), SIST AH Ag (Ácido húmico em água do sistema contendo AgNP).

Ao comparar todos os sistemas, considerando a ausência/presença de AH, não foi observado um padrão similar quanto à formação de agregados de nanopartículas. Assim, os agregados da amostra AgNP REC AH, a partir das 24 horas, foram maiores $(>1200$ 
nm) quando comparados com a amostra AgNP REC e AH REC. Por outro lado, as amostras AgNP MQ, AgNP MQ AH, AgNP SIST, AgNP SIST AH apresentaram tamanhos semelhantes, os quais não ultrapassaram os $250 \mathrm{~nm}$. Nas amostras que continham AH foi observada uma diminuição, embora discreta, no tamanho dos agregados quando comparadas com as amostras sem $\mathrm{AH}$.

Na Figura 28 estão apresentados os valores obtidos do potencial zeta obtidos para as diferentes amostras avaliadas. Observamos que esses valores nos diferentes meios aquosos variaram dependendo da quantidade de sais, encontrando que o potencial zeta foi maior para as AgNP na água MQ, seguido pela água SIST e por último a água REC. Adicionalmente, esses valores obtidos apresentaram um aumento ao longo do tempo, destacando que as AgNP na presença do AH (em água REC, SIST ou MQ) apresentaram maior carga superficial do que as nanopartículas sem a presença de $\mathrm{AH}$.

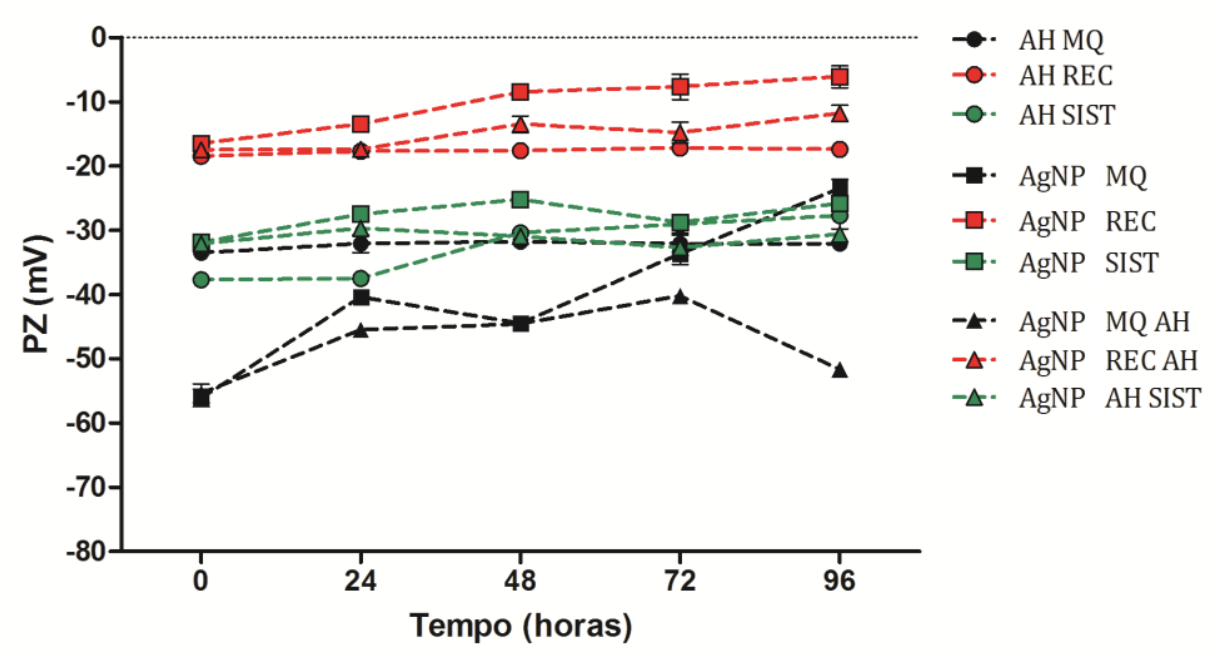

Figura 28. Valores do potencial zeta das AgNP (30 mg/L) na presença de AH (20 mg/L), em água MQ, REC e SIST. Os dados correspondem às medidas obtidas diariamente, por 96 horas, após sonicação, e estão representados pela Média \pm Desvio Padrão. MQ AH (Ácido húmico em água ultrapura), MQ Ag (água ultrapura contendo AgNP), MQ AH Ag (Ácido húmico em água ultrapura contendo AgNP), REC AH (Ácido húmico em água reconstituída), REC Ag (água reconstituída contendo AgNP), REC AH Ag (Ácido húmico em água reconstituída contendo AgNP), SIST AH (Ácido húmico em água do sistema), SIST Ag (água do sistema contendo AgNP), SIST AH Ag (Ácido húmico em água do sistema contendo AgNP).

A Figura 29 elaborou-se a fim de facilitar a observação dos resultados obtidos às 96 horas, tanto para o diâmetro hidrodinâmico (Figura 29A) como para o potencial zeta (Figura 29B). Observa-se que tanto a água MQ como SIST proporcionam condições 
similares às AgNP, o que pode ser observado nos valores do diâmetro hidrodinâmico (Figura 29A). Esses valores indicam que as AgNP na presença de AH (água MQ e SIST) formaram agregados de menor tamanho do que as nanopartículas sem o AH (AgNP MQ e AgNP SIST). Em contraste, a amostra AgNP REC AH formaram se agregados de maior tamanho quando comparadas com a amostra AgNP REC. No entanto, os valores do potencial zeta (Figura 29B), para as todas amostras que continham AH (AgNP MQ AH, AgNP REC AH e AgNP SIST AH), foi maior do que para as amostras AgNP MQ, AgNP REC e AgNP SIST. Aliás, os valores do potencial zeta foram inversos à concentração de sais presentes nos diferentes sistemas aquosos testados. Deste modo, encontrou-se que as AgNP REC AH apresentaram valores menores no potencial zeta do que as AgNP SIST AH e AgNP MQ AH. Os valores negativos no potencial zeta podem ser devidos à adsorção do AH na superfície das AgNP, a qual se observa nas micrografias eletrônicas de transmissão (Figura 30C), indicado pela seta. Assim, os resultados indicam que a carga superficial das AgNP é influenciada pela presença de AH e sais no meio.
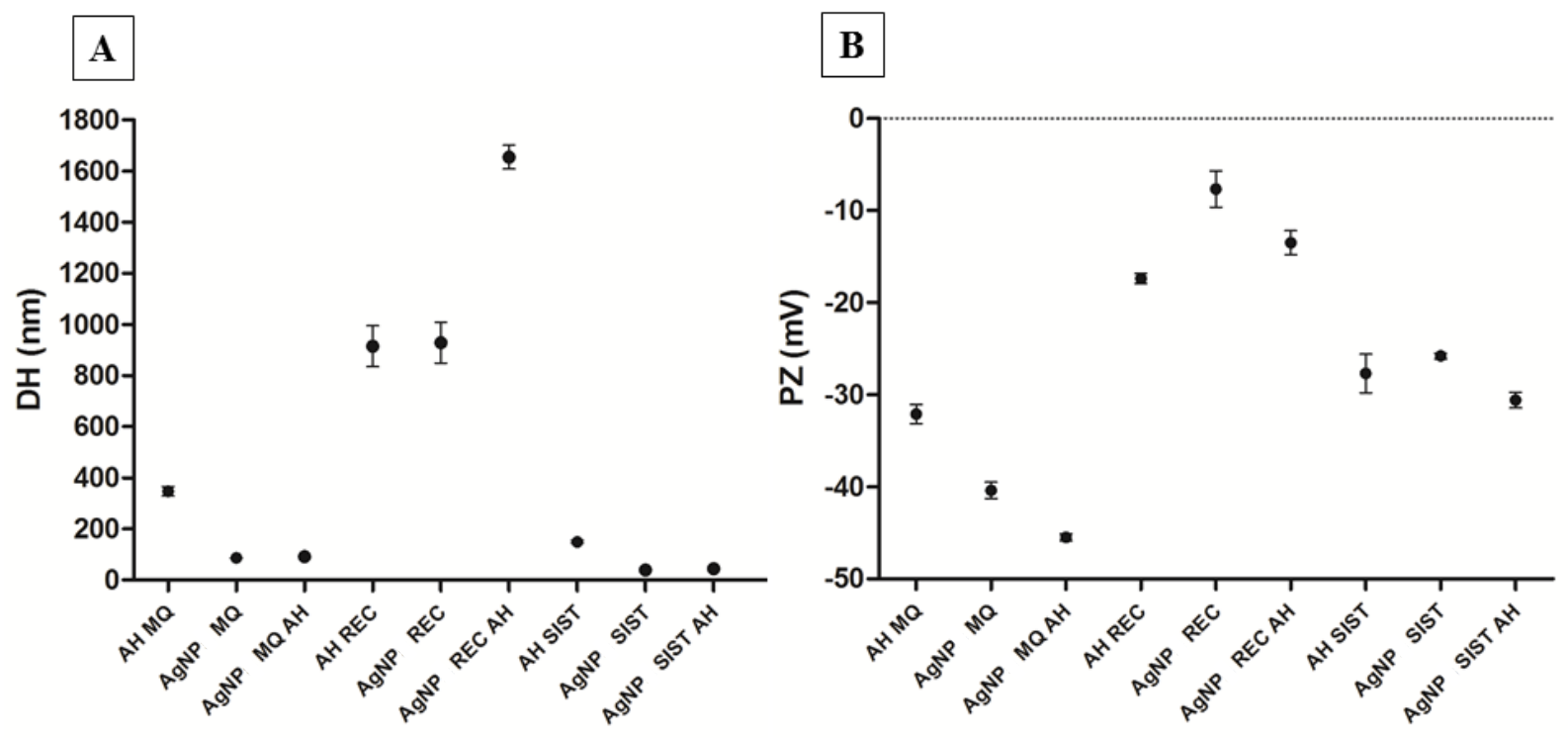

Figura 29. Valores do diâmetro hidrodinâmico (A) e potencial zeta (B) das AgNP (30 mg/L) na presença de $\mathrm{AH}(20 \mathrm{mg} / \mathrm{L})$, em água MQ, REC e SIST. Os dados correspondem às medidas após 96 horas da sonicação, e estão representados pela Média \pm Desvio Padrão. MQ AH (Ácido húmico em água ultrapura), MQ Ag (água ultrapura contendo AgNP), MQ AH Ag (Ácido húmico em água ultrapura contendo AgNP), REC AH (Ácido húmico em água reconstituída), REC Ag (água reconstituída contendo AgNP), REC AH Ag (Ácido húmico em água reconstituída contendo AgNP), SIST AH (Ácido húmico em água do sistema), SIST Ag (água do sistema contendo AgNP), SIST AH Ag (Ácido húmico em água do sistema contendo AgNP). 


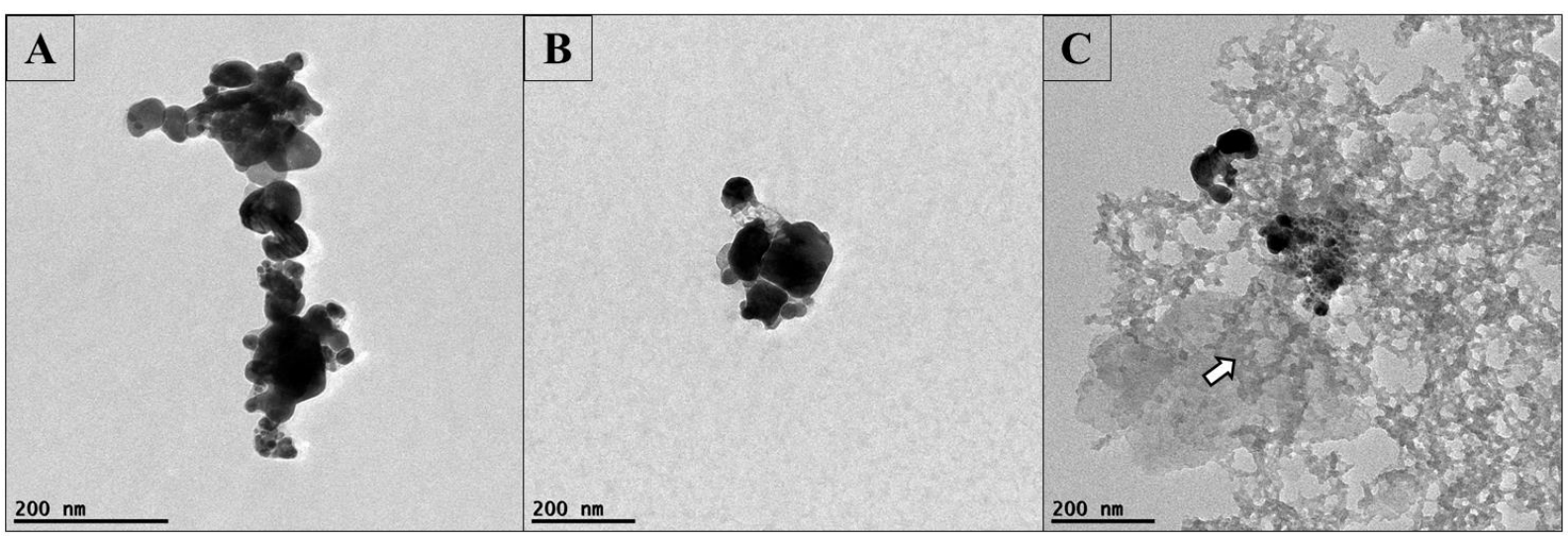

Figura 30. Micrografias eletrônicas de transmissão das AgNP (30 mg/L) com e sem a presença de AH (20 mg/L), após 96 horas da sonicação. AgNP suspensas em metanol (A), em água ultrapura (B), em água ultrapura com $\mathrm{AH}(\mathrm{C})$. As áreas mais elétron-densas correspondem às AgNP e as de menor elétron-densidade ao AH (seta). A contrastação negativa foi realizada com acetato de uranila $(0,05 \%)$.

\subsection{ADSORÇÃo E MODIFICAÇões do ÁCIDO HÚMICO NA PRESENÇA DAS NANOPARTÍCULAS DE PRATA}

Uma vez que os diferentes grupos funcionais do $\mathrm{AH}$ (grupamentos carboxílicos e fenólicos) possuem alta capacidade de complexação com as AgNP, foram realizadas análises por espectroscopia no infravermelho por refletância total atenuada com transformada de fourier (ATR-FTIR) a fim de corroborar essa interação. A utilização dessa técnica permitiu identificar deslocamentos no stretching assimétrico e simétrico do grupamento carboxila, localizados em 1562,8 e $1378 \mathrm{~cm}^{-1}$. Na Figura 31 estão ilustrados os espectros (Figura 31A) e os números de onda (Figura 31B) onde foram observadas as mudanças no AH após 1, 2 e 3 horas de interação com as AgNP. Adicionalmente, uma nova banda foi observada (ver em detalhe na Figura 31B) entre os picos do stretching assimétrico e simétrico em cada tempo de interação, como se mostra na figura 31A e B. Quando considerada a separação do número de onda entre as bandas IR assimétricas e simétricas COO- a diferença $(\Delta)$ do número de onde foi de $204 \mathrm{~cm}^{-1}$. 


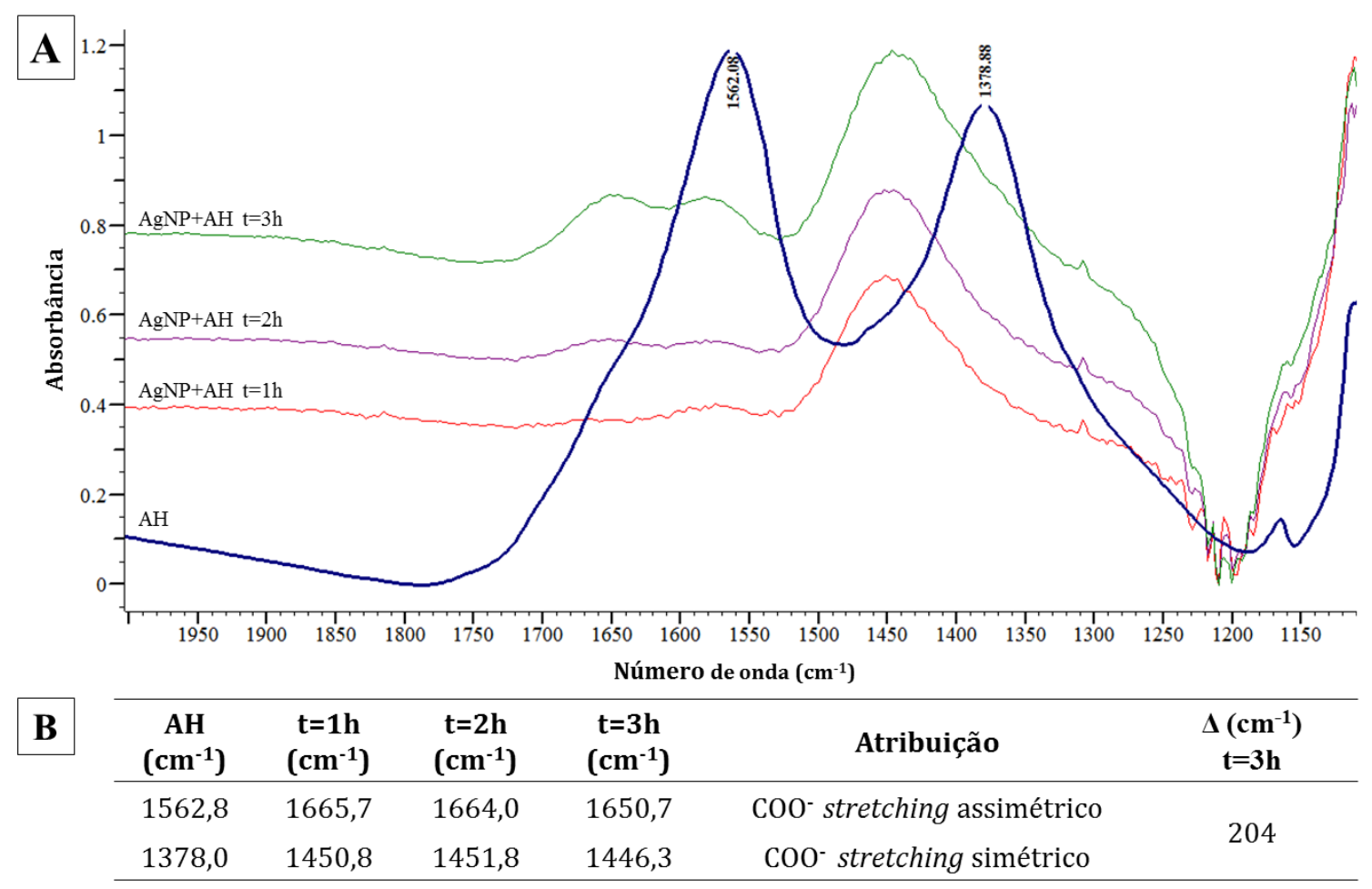

Figura 31. Análise por ATR-FTIR do filme de AH (100 mg/mL depositado no cristal de ZnSe) e AH adsorvido no filme de AgNP (3 mg/mL) depositado no cristal ZnSe. (A) Os dados foram adquiridos após 1, 2 e 3 horas do preparo. (B) Representação dos valores dos picos. Na faixa de 2000-1100 $\mathrm{cm}^{-1}$ foram observadas mudanças no stretching assimétrico e simétrico do COO-

\subsection{MODIFICAÇÕES NA SUPERFÍCIE DAS NANOPARTÍCULAS DE PRATA EM DIFERENTES MEIOS AQUOSOS}

A fim de conhecer as mudanças na superfície das AgNP, causada pelo ambiente aquoso (MQ, REC, SIST), foram realizados experimentos e análises em diferentes tempos após o preparo das nanopartículas. Desta maneira, nas Figuras 32-35 e na Tabela 7 estão representados os resultados obtidos no primeiro experimento, segundo o descrito no item 4.7 dos materiais e métodos (Modificações na superfície das nanopartículas de prata em diferentes meios aquosos). Especificamente os espectros para as AgNP suspendidas em água $\mathrm{MQ}$, sem e com a presença de $\mathrm{AH}$, estão representados nas Figuras 32A-D e 32E-H, respectivamente. Nas Figuras 33A-D encontram-se os espectros para as AgNP suspendidas em água reconstituída sem a presença de AH e nas Figuras 33E-H para as AgNP com AH. Do mesmo modo, os resultados obtidos para as AgNP suspendidas em água do sistema sem presença de AH estão representados nas Figuras 34A-D, e com AH nas Figuras 34E-H. 
Na Figura 32 (A-D) observamos os espectros obtidos por XPS, das amostras de AgNP em água MQ nos diferentes tempos experimentais (0, 24, 48 e 96 horas), onde as posições dos picos Ag 3d $\mathrm{d}_{5 / 2}$ próximo de 368,4 eV indicam que as amostras de AgNP, para cada tempo, correspondem a prata metálica (MOULDER et al., 1995), ou seja as AgNP não apresentaram mudanças no estado de oxidação, em pH neutro, permanecendo como Ag (0) ao longo do tempo experimental, tal como se tinha encontrado nos resultados anteriores (Figura 16). Embora a qualidade dos espectros das amostras analisadas de AgNP em água REC e SIST foram menores, observaram-se os picos nas mesmas posições (Figuras 33A-D e 34A-D) que para a prata metálica Ag (0).

A Tabela 7 mostra os parâmetros Auger obtidos para amostras de AgNP em água MQ, REC e SIST. Os parâmetros Auger calculados para as amostras de AgNP suspendidas em água MQ e SIST mostram que as nanopartículas não apresentaram mudanças no estado de oxidação, permanecendo em estado $\mathrm{Ag}(0)$ com pico $\mathrm{Ag} 3 \mathrm{~d}_{5 / 2}$ próximo de 368,4 eV, indicando que as amostras de AgNP em água MQ e SIST com e sem AH (Ag AH MQ), para cada tempo, correspondem à prata metálica (MOULDER et al., 1995). No entanto, para as AgNP suspendidas em água REC com a presença de AH (Figuras 33E-H), os resultados indicaram que houve mudanças significativas nos espectros das amostras ao longo do tempo, quando comparadas com as amostras sem AH (Figuras 33A-D), onde não se observaram mudanças no estado de oxidação da prata. Os espectros $\mathrm{Ag} 3 \mathrm{~d}$ das amostras de AgNP em água REC com AH, apresentadas na Figuras 33E-H, mostraram a presença de dois estados diferentes, um para Ag (0) com pico Ag 3d $\mathrm{d}_{5 / 2}$ próximo de 368,4 eV e outro para Ag (III) com pico Ag 3 $\mathrm{d}_{5 / 2}$ em torno de 370,4 eV (MOULDER et al., 1995). É claramente visível que o componente associado ao estado Ag (III) aumenta ao longo do tempo, estabelecendo-se uma diferença notória entre as amostras de AgNP sem AH (Figura 33A-D). Estes resultados indicam que a presença do $\mathrm{AH}$, possivelmente, influiu na mudança do estado de oxidação de Ag (0) para Ag (III) nas amostras de AgNP analisadas. Esta mudança no estado de oxidação foi observada também no parâmetro Auger calculado para essa amostra (Figura 35). 
A

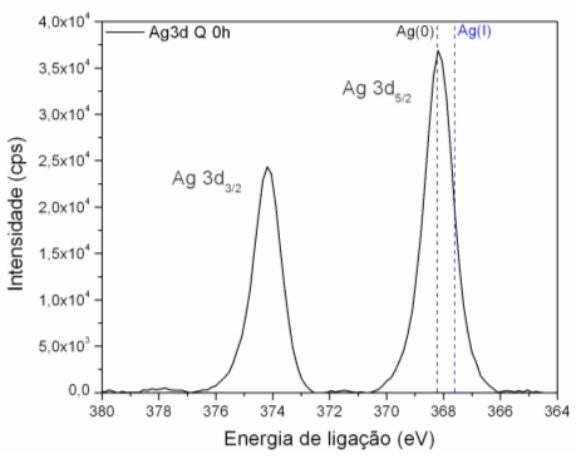

B

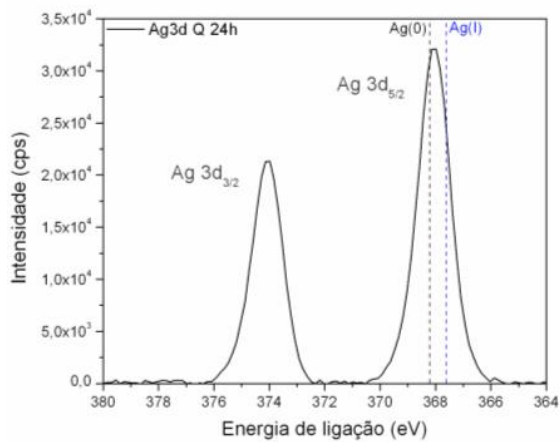

C

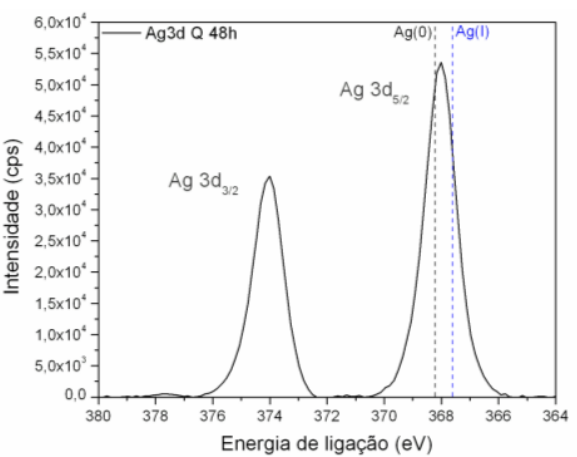

$\mathrm{D}$

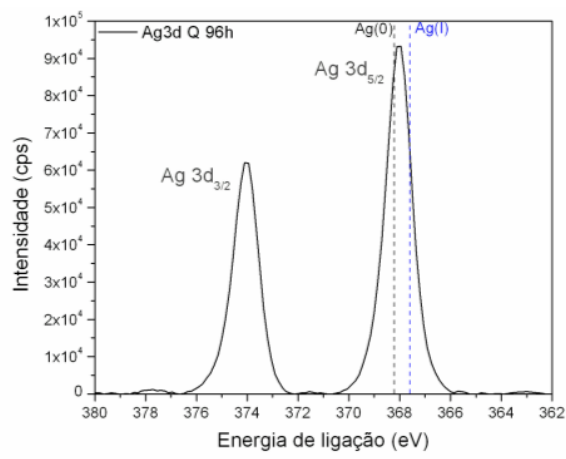

E

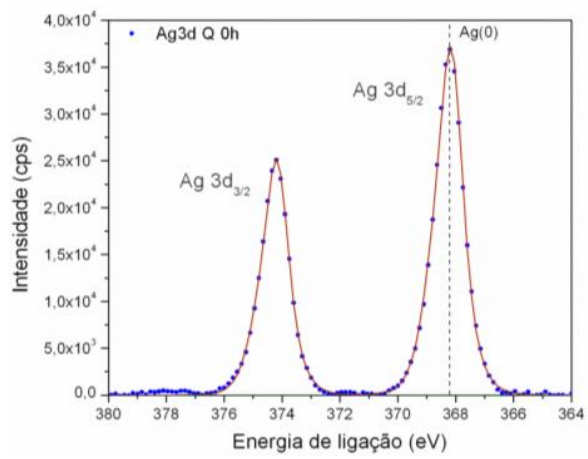

F

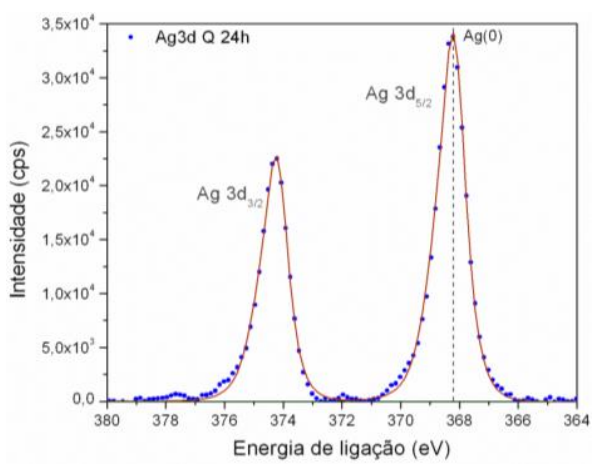

G

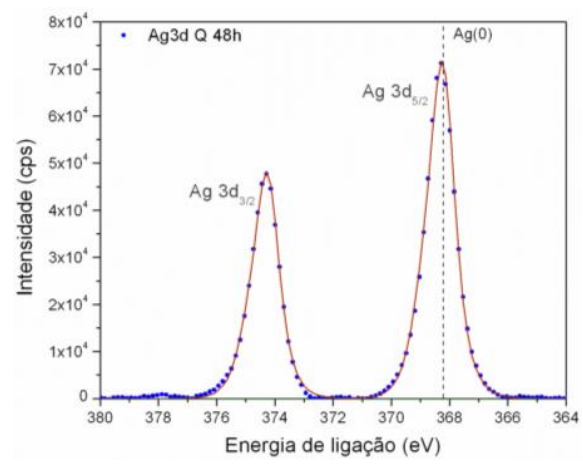

$\mathrm{H}$

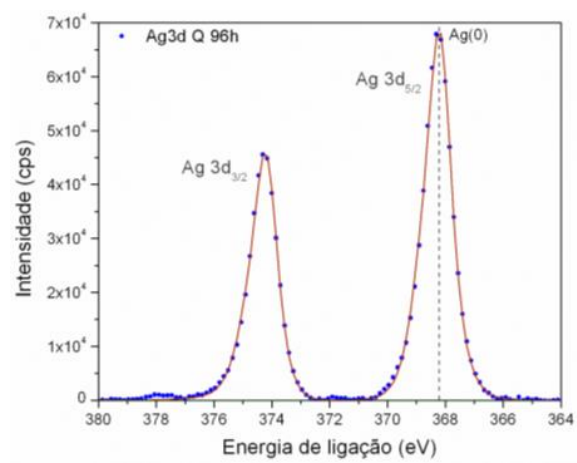

Figura 32. Espectros XPS das amostras de AgNP suspendidas em água deionizada. Espectros XPS das AgNP suspendidas em água $M Q$ sem a presença de $\mathrm{AH}$, nos diferentes tempos experimentais 0 (A), 24 (B), 48 (C) e 96 (D) horas. Espectros XPS das amostras de AgNP em água MQ contendo AH, nos diferentes tempos experimentais 0 (E), 24 (F), $48(\mathrm{G})$ e $96(\mathrm{H})$ horas. As posições dos picos $( \pm 368,4 \mathrm{eV})$ nos espectros A-H indicam que as amostras correspondem ao estado de valência da prata, $\mathrm{Ag}$. 
A

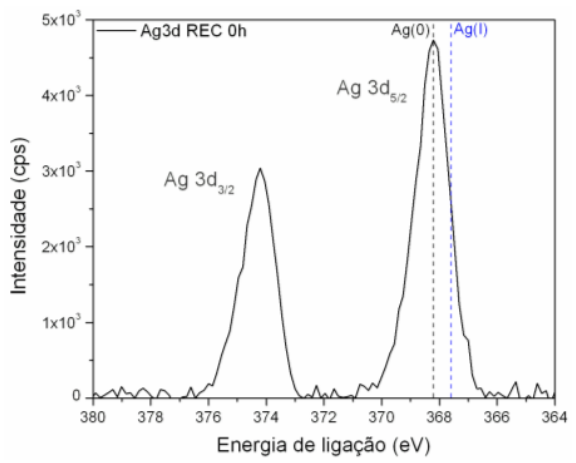

B

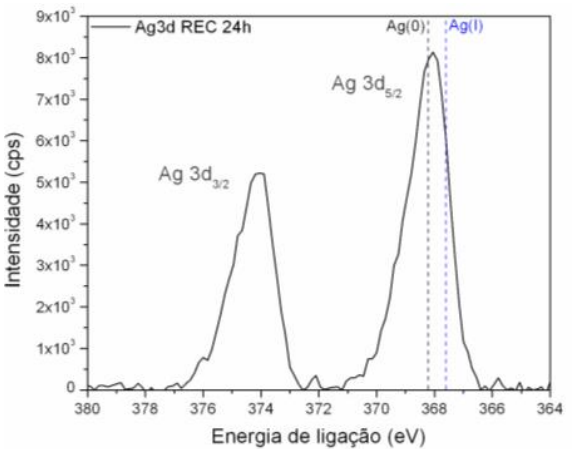

C

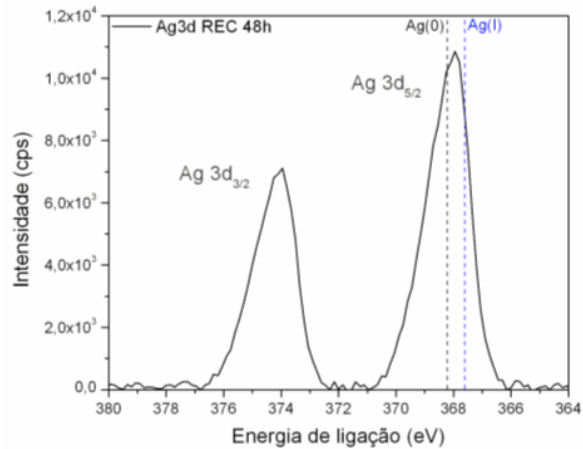

D

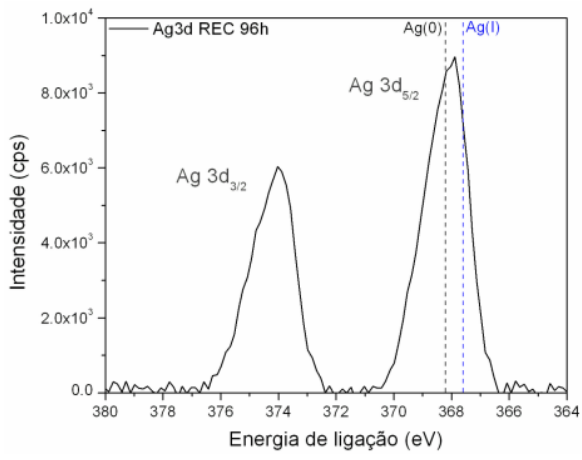

E

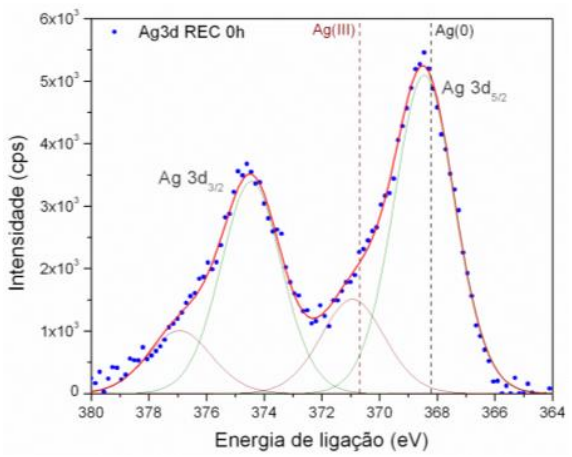

$\mathrm{F}$

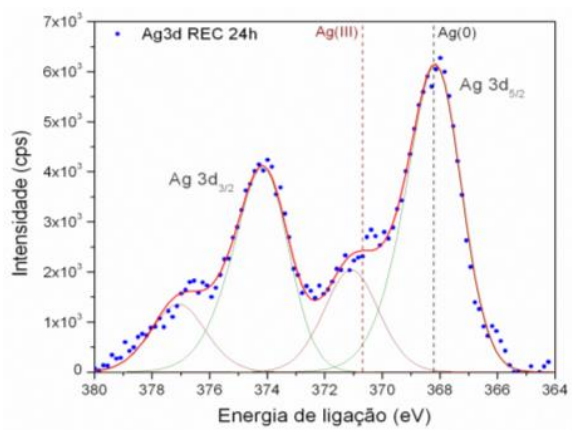

G

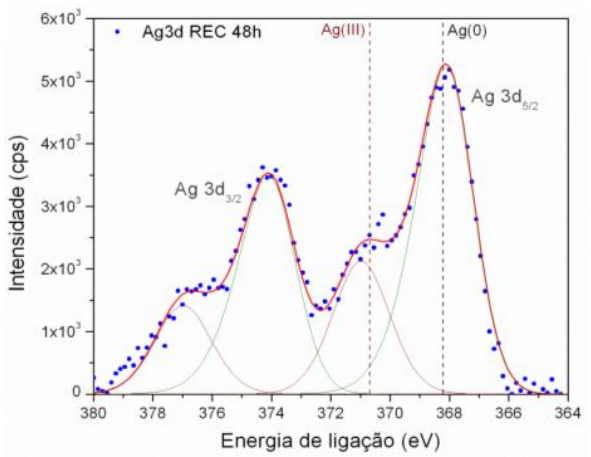

$\mathrm{H}$

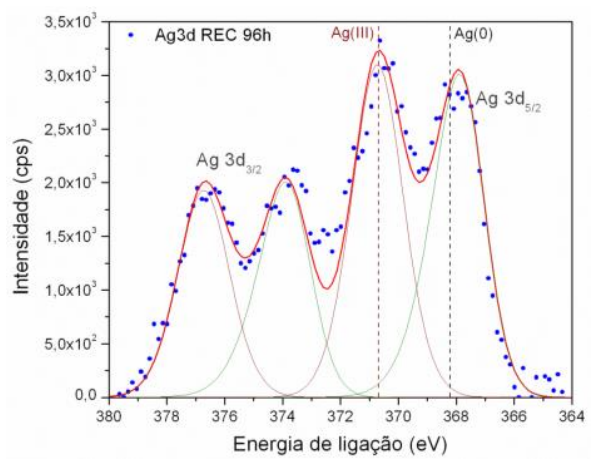

Figura 33. Espectros XPS das amostras de AgNP suspendidas em água reconstituída. Espectros XPS das AgNP suspendidas em água REC sem a presença de $\mathrm{AH}$, nos diferentes tempos experimentais 0 (A), 24 (B), 48 (C) e 96 (D) horas. Espectros XPS das amostras de AgNP em água REC contendo AH, nos diferentes tempos experimentais 0 (E), 24 (F), 48 (G) e 96 (H) horas. As posições dos picos $( \pm 368,4 \mathrm{eV})$ nos espectros A-D indicam que as amostras correspondem ao estado de valência da prata, $\mathrm{Ag}^{0}$, enquanto que nos espectros $\mathrm{E}-\mathrm{H}$ se observa a presença de dois estados de valência da prata, $\mathrm{Ag}^{0}( \pm 368,4 \mathrm{eV}) \mathrm{e} \mathrm{Ag}^{3+}( \pm 370,4 \mathrm{eV})$. 
A

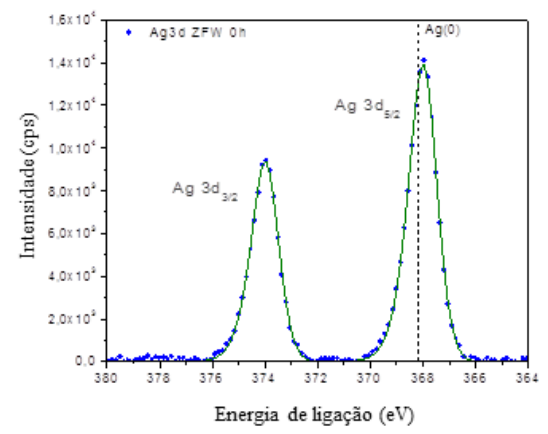

B

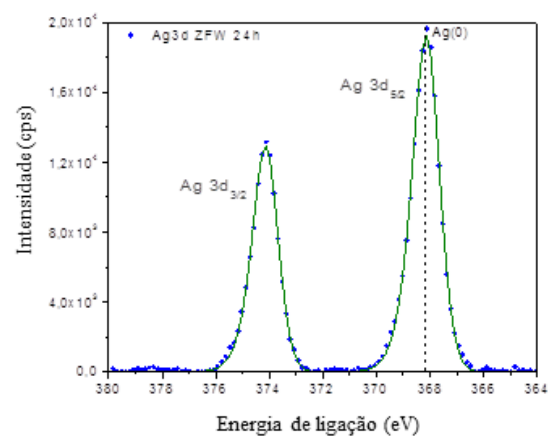

C

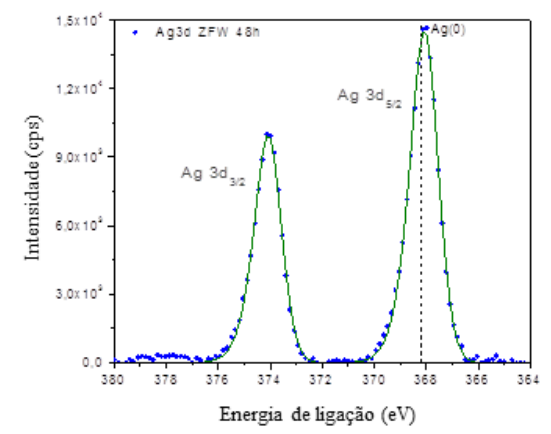

D

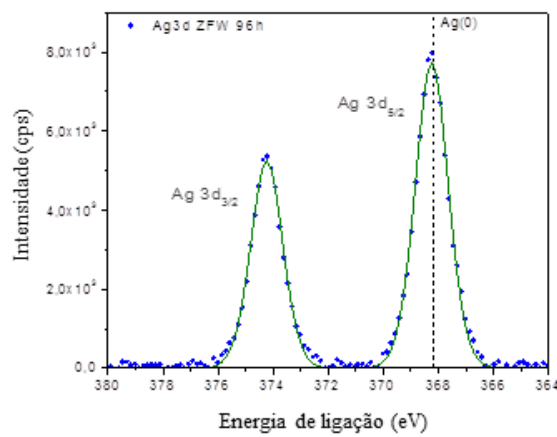

$\mathrm{E}$

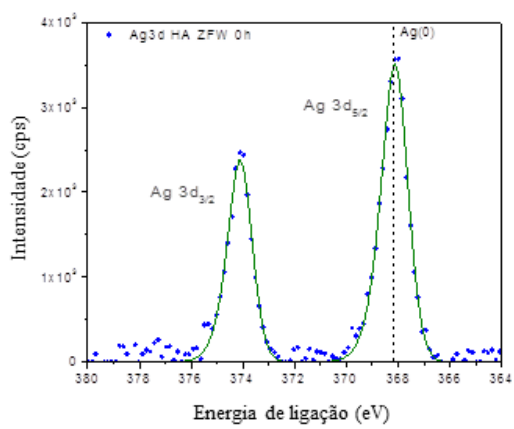

$\mathrm{F}$

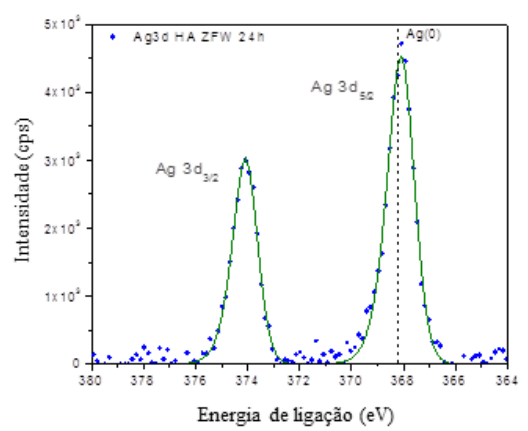

G

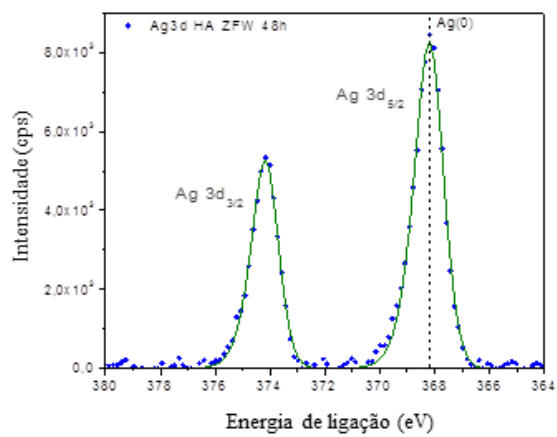

$\mathrm{H}$

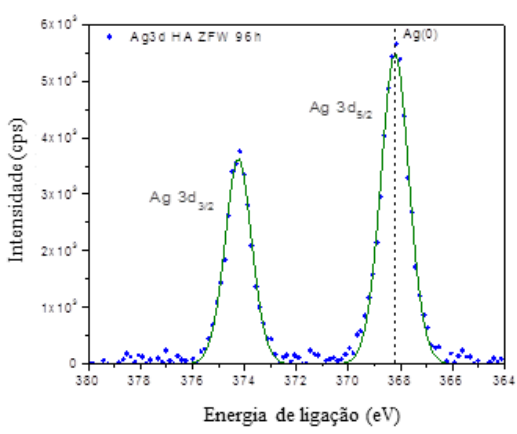

Figura 34. Espectros XPS das amostras de AgNP suspendidas em água do sistema. Espectros XPS das AgNP suspendidas em água SIST sem a presença de $\mathrm{AH}$, nos diferentes tempos experimentais 0 (A), 24 (B), 48 (C) e 96 (D) horas. Espectros XPS das amostras de AgNP em água SIST contendo AH, nos diferentes tempos experimentais 0 (E), 24 (F), 48 (G) e 96 (H) horas. As posições dos picos $( \pm 368,4 \mathrm{eV})$ nos espectros $\mathrm{A}-\mathrm{H}$ indicam que as amostras correspondem ao estado de valência da prata, Ag0. 
Tabela 7. Parâmetro Auger calculado para as amostras de AgNP em água MQ, REC e SIST nos tempos $0,24,48$, e 96 horas após sonicação.

\begin{tabular}{|c|c|c|c|c|}
\hline AMOSTRAS & $\begin{array}{c}\text { TEMPO } \\
\text { (h) }\end{array}$ & $\begin{array}{c}\operatorname{Ag~3d} 5 / 2 \\
\text { (ev) }\end{array}$ & $\begin{array}{l}\text { AUGER M } 4 \text { VV } \\
(\mathrm{eV})\end{array}$ & $\begin{array}{c}\text { PARÂMETRO AUGER } \\
(\mathrm{eV})\end{array}$ \\
\hline \multirow{4}{*}{ AgNP MQ } & 0 & 367,75 & 895,2 & 726,2 \\
\hline & 24 & 367,54 & 894,92 & 726,2 \\
\hline & 48 & 367,51 & 894,92 & 726,2 \\
\hline & 96 & 367,72 & 895,12 & 726,2 \\
\hline \multirow{4}{*}{ AgNP REC } & 0 & 367,73 & 895,01 & 726,3 \\
\hline & 24 & 367,41 & 895,31 & 725,7 \\
\hline & 48 & 367,43 & 895,08 & 726,0 \\
\hline & 96 & 367,42 & 894,76 & 726,3 \\
\hline \multirow{4}{*}{ AgNP SIST } & 0 & 367,42 & 894,92 & 726,10 \\
\hline & 24 & 367,34 & 894,76 & 726,18 \\
\hline & 48 & 367,37 & 894,88 & 726,09 \\
\hline & 96 & 369,24 & 896,76 & 726,08 \\
\hline
\end{tabular}

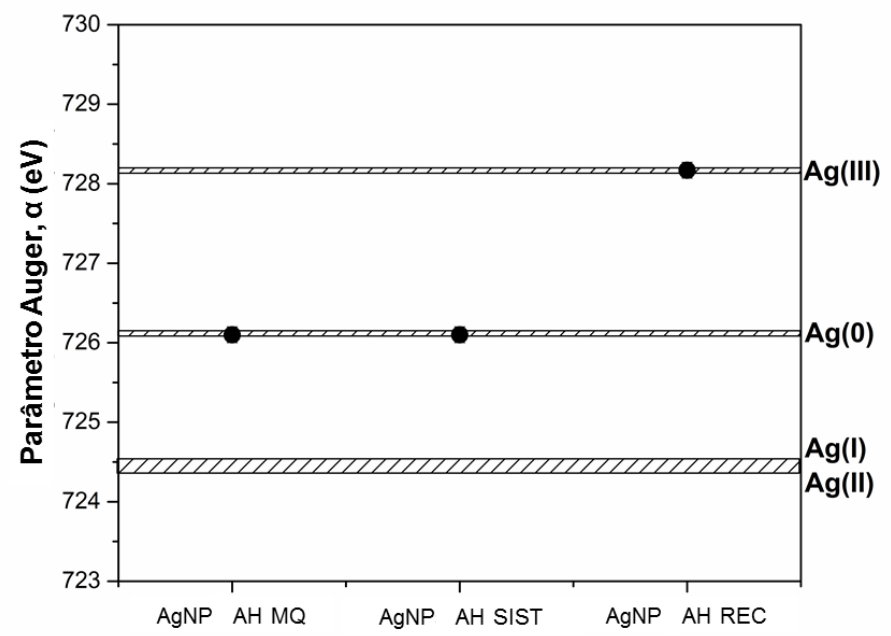

Figura 35. Parâmetro Auger calculado para as amostras de AgNP em água MQ, SIST e REC com a presença de AH no tempo 96 horas após sonicação. 
As figuras abaixo mostram os espectros C 1s para as AgNP suspendidas em água MQ (Figuras 36A-D), REC (Figuras 37-D) e SIST (Figuras 38A-D), obtidos nos tempos 0, 24, 48 e 96 horas após o preparo. Os espectros C 1s de todas as amostras mostram os picos associados a ligações C-C/C-H em 285,0 eV, ligações C-O em 286,5 eV, ligações C=0 e $\mathrm{O}=\mathrm{C}-\mathrm{OH}$ ao redor de $288,5 \mathrm{eV}$ e carbonatos em $290,2 \mathrm{eV}$.

Por outro lado, nas Figuras 36E-H, 37E-H e 38E-H estão representados os espectros para o oxigênio (0 1s) que correspondem às AgNP suspendidas em água MQ, REC e SIST, respectivamente. Nestas figuras podemos observar que as posições esperadas para as ligações Ag-O, oxigênio em carbonatos, $\mathrm{C}=\mathrm{O}$, e C-O-C estão ao redor de 529,$2 ; 531,0 ; 532,0$ e 533,3 eV; respectivamente. 0 componente relacionado com as ligações Ag-O foi observado somente nas AgNP suspendidas em água REC, analisada às 96 horas após o preparo. Estes resultados corroboram os dados representados na Figura $33 \mathrm{H}$, onde se observou a presença do componente para Ag (III) com alta intensidade no espectro Ag 3d para esta amostra, e também no parâmetro Auger calculado (Figura 35). 
A

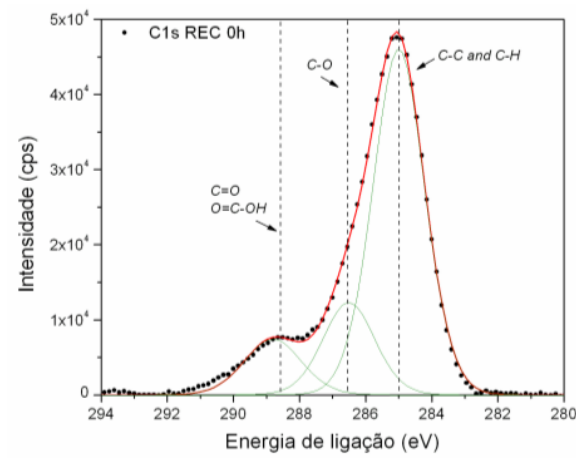

B

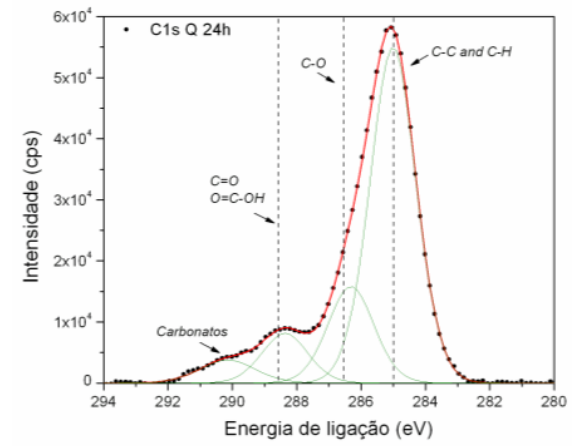

C

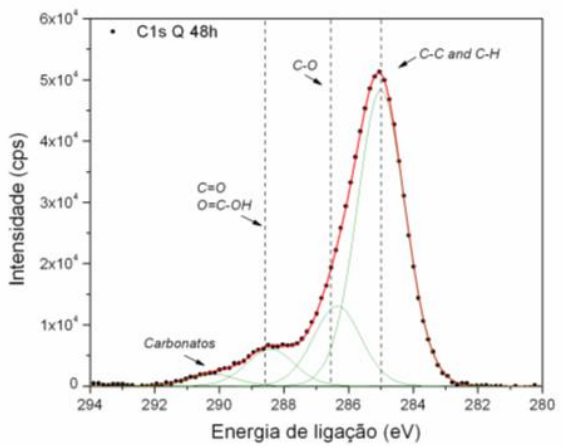

D

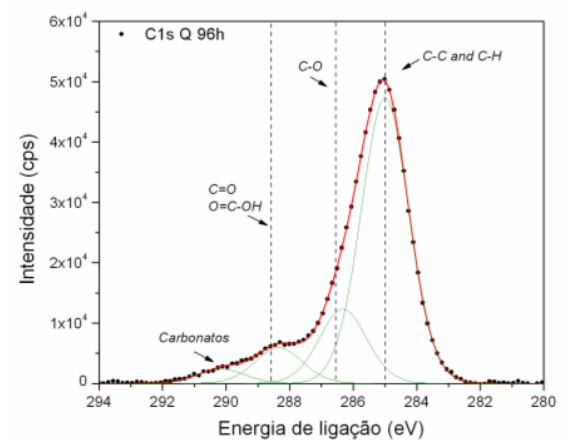

E

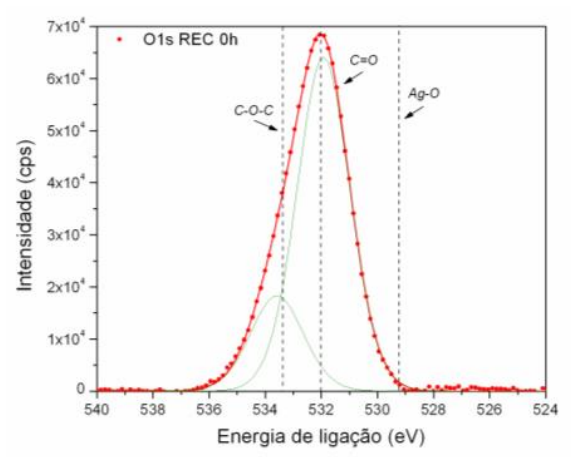

F

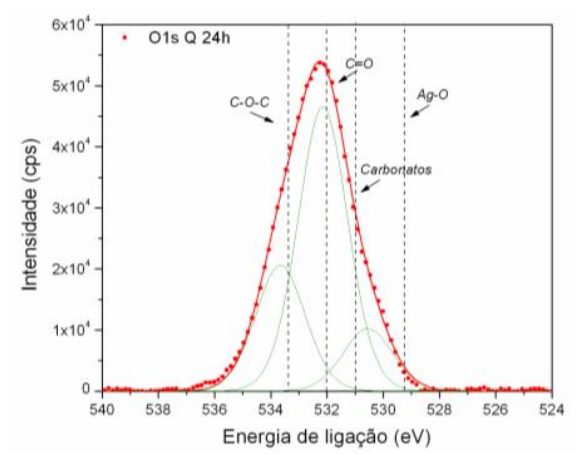

G

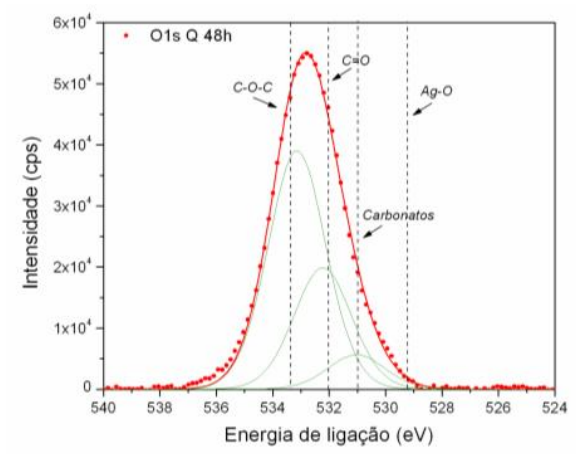

$\mathrm{H}$

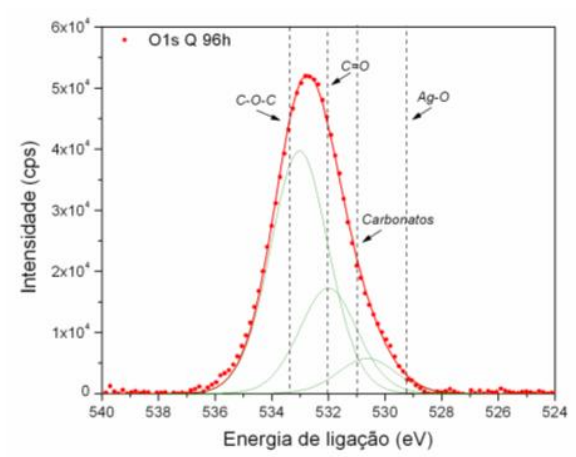

Figura 36. Espectros XPS das amostras de AgNP (1 mg/mL), dispersas em água MQ com AH (1 mg/L) obtidos às 0 (a), 24 (b), 48 (c) e 96 (d) horas após sonicação. Regiões da energia de ligação do carbono (A-D) e do oxigênio $(\mathrm{E}-\mathrm{H})$. Os picos indicados pelas setas correspondem às diferentes energias de ligação encontradas para o carbono e o oxigênio, indicando a presença do AH nas amostras. 
A

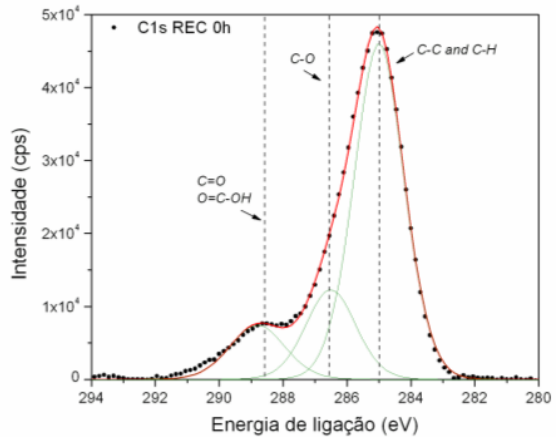

B

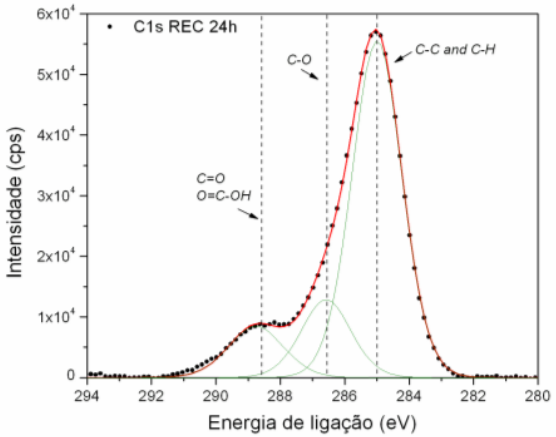

C

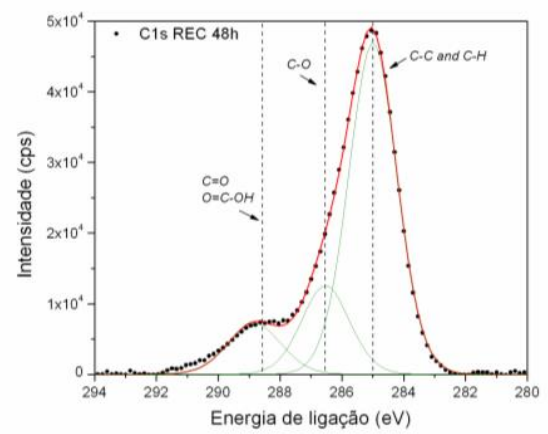

$\mathrm{D}$

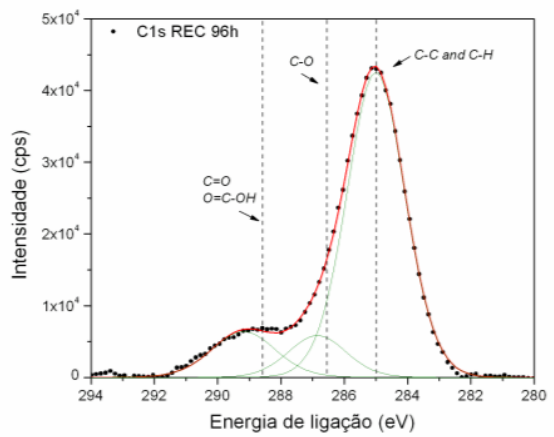

$\mathrm{E}$

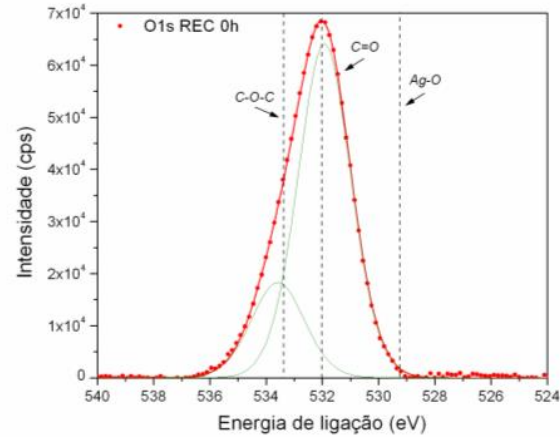

$\mathrm{F}$

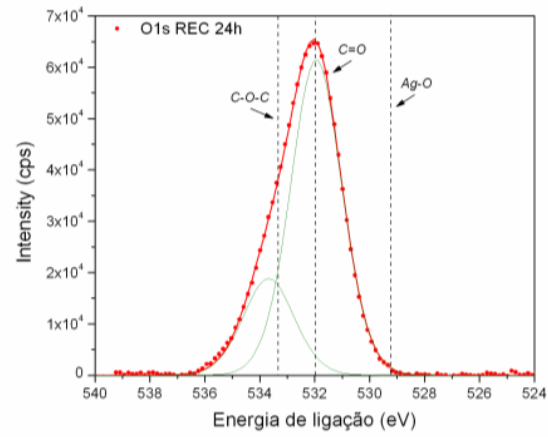

G

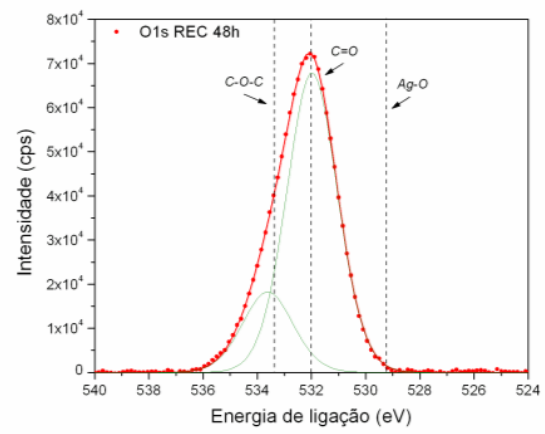

$\mathrm{H}$

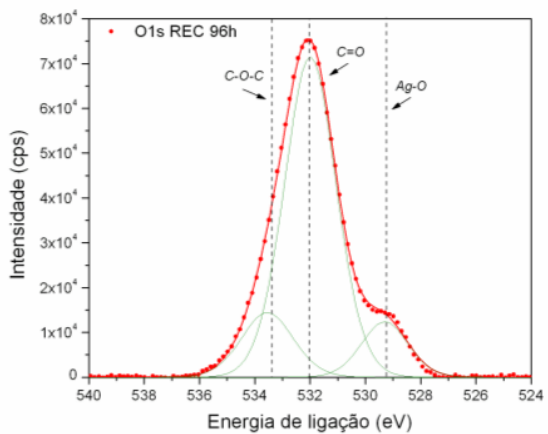

Figura 37. Espectros XPS das amostras de AgNP (1 mg/mL), dispersas em água REC com AH (1 mg/L) obtidos às 0 (a), 24 (b), 48 (c) e 96 (d) horas após sonicação. Regiões da energia de ligação do carbono (A-D) e do oxigênio $(\mathrm{E}-\mathrm{H})$. As setas indicam os picos correspondentes às diferentes energias de ligação encontradas para o carbono e o oxigênio, indicando a presença de AH nas amostras. Na figura H é possível observar o pico associado à energia de ligação Ag-O. 
A

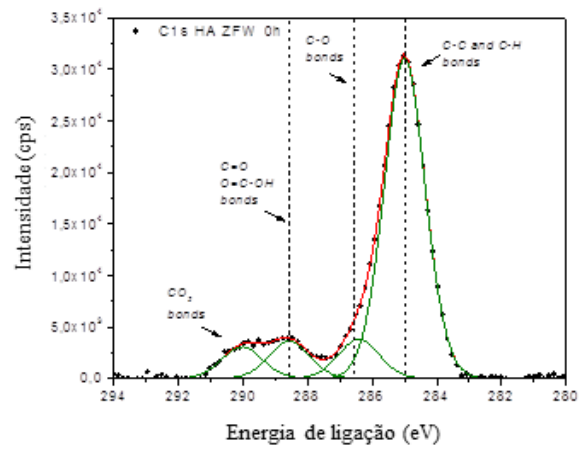

B

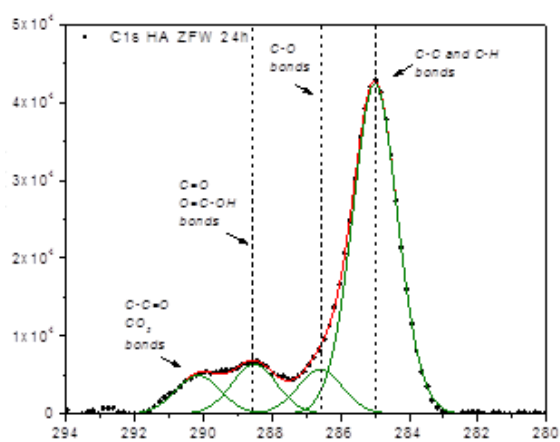

C

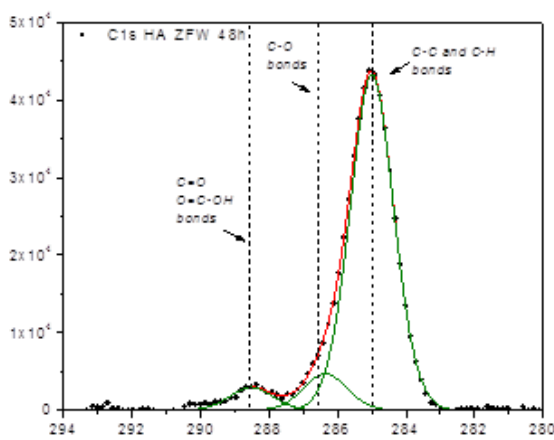

$\mathrm{D}$

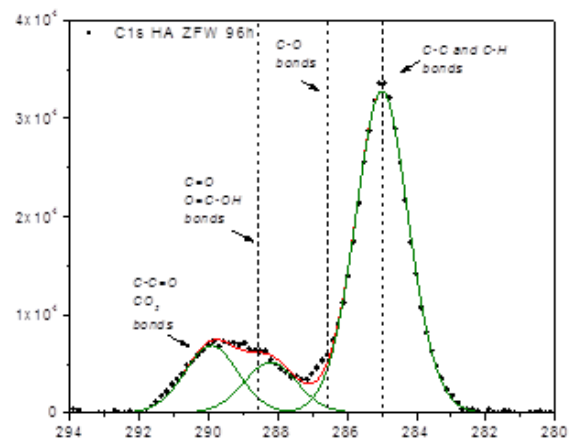

$\mathrm{E}$

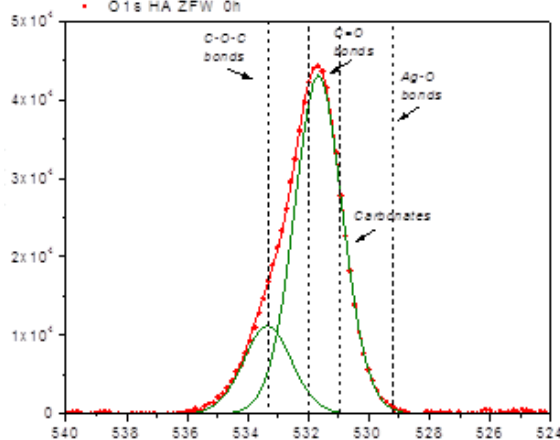

$\mathrm{E}$

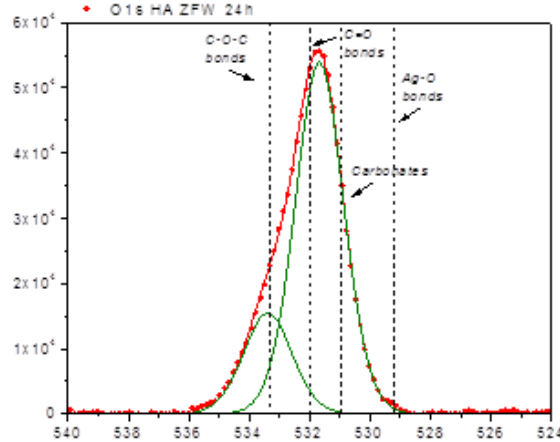

$\mathrm{F}$

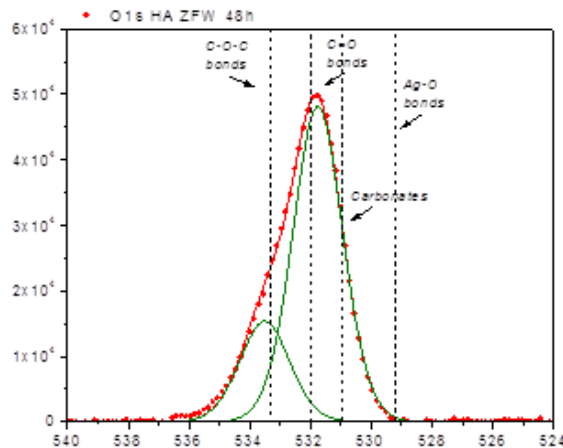

G

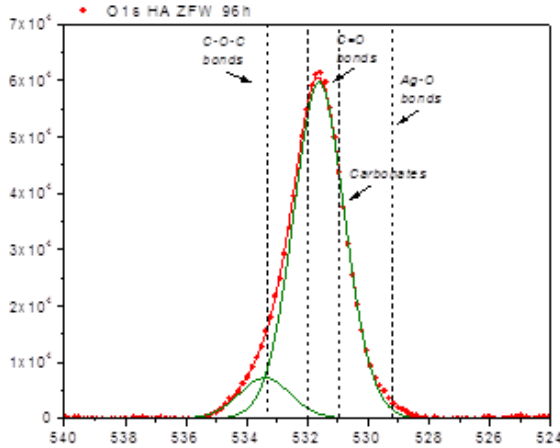

Figura 38. Espectros XPS das amostras de AgNP $(1 \mathrm{mg} / \mathrm{mL})$, dispersas em água SIST com AH (1 mg/L) obtidos às 0 (a), 24 (b), 48 (c) e 96 (d) horas após sonicação. Regiões da energia de ligação do carbono (A-D) e do oxigênio $(\mathrm{E}-\mathrm{H})$. Os picos indicados pelas setas correspondem às diferentes energias de ligação encontradas para o carbono e o oxigênio, indicando a presença do AH nas amostras. 
O segundo experimento foi realizado a fim de conhecer a influência do AH e dos sais utilizados no preparo da água REC na oxidação das AgNP. Assim, na Figura 39 estão ilustrados os espectros obtidos para cada meio aquoso contendo $\mathrm{NaHCO}_{3}$ (Figura 39B), $\mathrm{KCl}$ (Figura 39C), $\mathrm{CaCl}_{2}$ (Figura 39D) e $\mathrm{MgSO}_{4}$ (Figura 39E), observando que as AgNP que apresentaram maior porcentagem de oxidação, correspondendo à presença de Ag (III), foram as suspendidas em água contendo $\mathrm{NaHCO}_{3}$ (29\%), seguido por $\mathrm{KCl}$ (18\%), $\mathrm{MgSO}_{4}$ (15\%) e $\mathrm{CaCl}_{2}$ (14\%). As porcentagens atômicas relativas para os dois estados de valência da prata para cada espectro estão representadas nos quadros à direita dos espectros da Figura 39.

A partir da observação que o $\mathrm{NaHCO}_{3}$ foi o sal que mais influenciou a oxidação das AgNP, foram realizados experimentos estabelecendo como constante a presença deste sal na água. Desta maneira, nos espectros obtidos no terceiro experimento (Figura 40) foi possível observar que as AgNP se oxidaram em maior proporção quando suspendidas em água com $\mathrm{NaHCO}_{3}+\mathrm{MgSO}_{4}$ (38\%), seguido pelo $\mathrm{NaHCO}_{3}+\mathrm{KCl}$ (19\%). As AgNP suspendidas em água com $\mathrm{NaHCO}_{3}+\mathrm{CaCl}_{2}$ não apresentaram mudanças no estado de oxidação, permanecendo como Ag (0). As porcentagens atômicas relativas para o nitrogênio, oxigênio, carbono, cálcio e os dois estados de valência da prata para cada espectro estão representados nos quadros à direita dos espectros da Figura 40. 


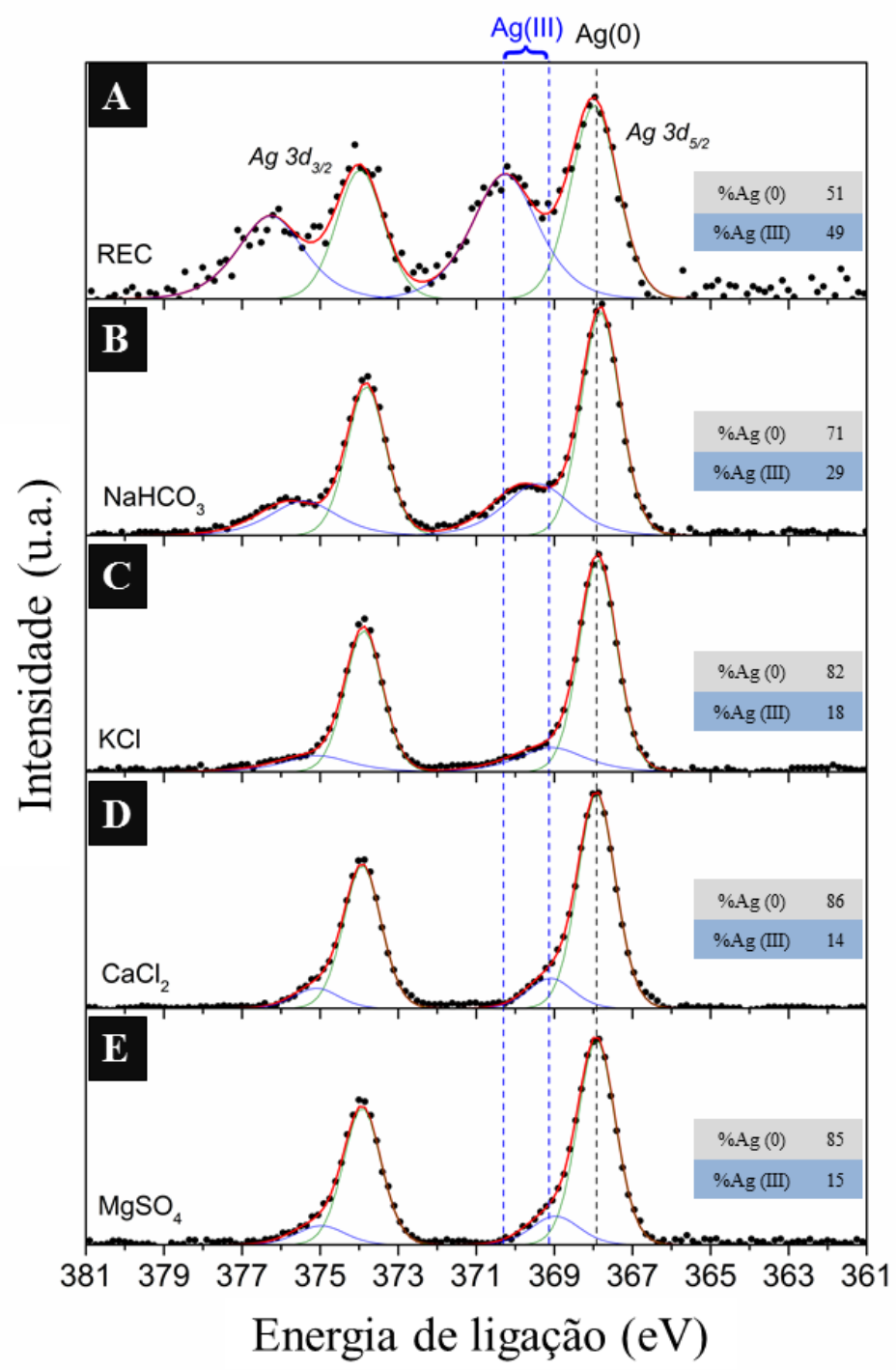

Figura 39. Espectros XPS das amostras de AgNP $(1 \mathrm{mg} / \mathrm{mL})$ dispersas em diferentes meios aquosos com AH (1 mg/L), obtidos às 96 horas após sonicação. (A) Espectro XPS das AgNP dispersas em água reconstituída. Espectro XPS das AgNP dispersas em água contendo $\mathrm{NaHCO}_{3}$ (B), $\mathrm{KCl}$ (C), $\mathrm{CaCl}_{2}$ (D) e $\mathrm{MgSO}_{4}$ (E). As porcentagens atômicas relativas para os dois estados de valência da prata para cada espectro estão representadas nos quadros à direita. 


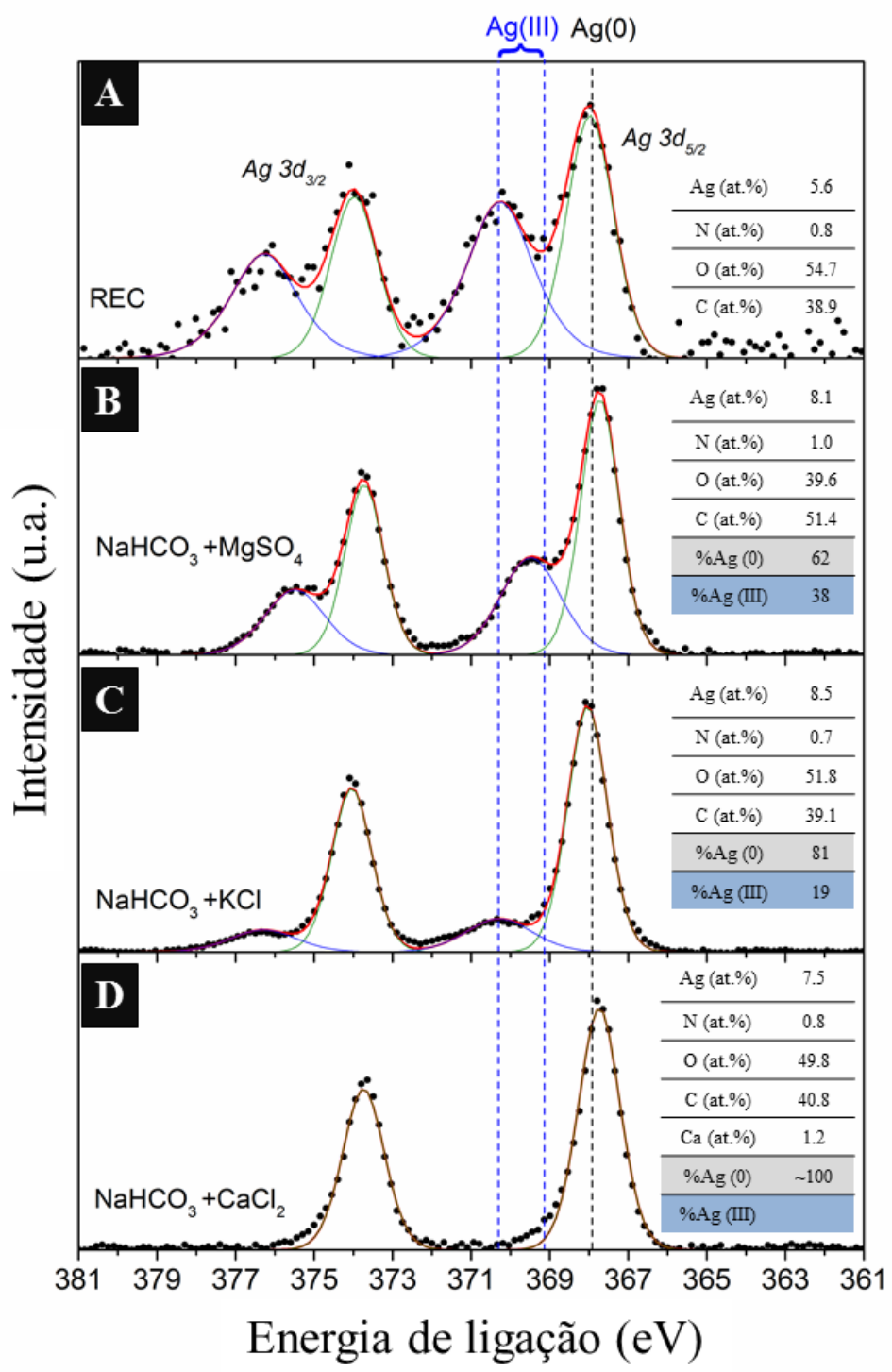

Figura 40. Espectros XPS das amostras de AgNP $(1 \mathrm{mg} / \mathrm{mL})$ dispersas em diferentes meios aquosos com AH (1 mg/L), obtidos às 96 horas após sonicação. (A) Espectro XPS das AgNP dispersas em água reconstituída. Espectro XPS das AgNP contendo $\mathrm{NaHCO}_{3}$ e $\mathrm{MgSO}_{4}$ (B), $\mathrm{NaHCO}_{3}$ e $\mathrm{KCl}$ (C), $\mathrm{NaHCO}_{3}$ e $\mathrm{CaCl}_{2}$ (D). As porcentagens atômicas relativas para o nitrogênio, oxigênio, carbono, cálcio e os dois estados de valência da prata para cada espectro estão representados nos quadros à direita. 


\subsection{ESTUDO DA LIBERAÇÃO DE ÍONS DE PRATA}

Na Figura 41 está representada a quantidade de prata dissolvida (íons) após 96 horas da sonicação em água MQ, água REC e água SIST, a partir de diferentes concentrações de AgNP $(0 ; 0,5 ; 1,0 ; 3,0$ e $10 \mathrm{mg} / \mathrm{L})$, com e sem a presença de AH (20 $\mathrm{mg} / \mathrm{L}$ ). Os dados sugerem que os íons liberados (durante 96 horas), em todas as concentrações avaliadas, foram maiores para as amostras suspendidas na água $\mathrm{MQ}$ (Figura 41A), SIST (Figura 41B) e REC (Figura 41C) quando comparadas com o grupo controle (0 mg/L AgNP), com ou sem a presença de ácido húmico. Além disso a liberação foi concentração dependente, sendo maior para as maiores concentrações de AgNP suspendidas em todos os tipos de água nas condições utilizadas nos experimentos.

A quantidade de prata liberada foi menor nas amostras que continham AH. No entanto, a partir da concentração de 3,0 mg/L e $10 \mathrm{mg} / \mathrm{L}$ de AgNP suspendidas em água REC e SIST, respectivamente, foi observado que houve maior liberação de íons nas amostras que continham AH do que para as que não o continham. Além disso, para as AgNP suspendidas em água contendo AH foi observado que a maior quantidade de íons liberados ocorreu para as nanopartículas suspendidas na água REC, seguido pela água SIST e MQ, independente da concentração utilizada, atingindo valores até de 28,66; 9,36 e $0,99 \mu \mathrm{g} / \mathrm{L}$ de $\mathrm{Ag}$, respectivamente.

Na Figura 42 está representada a quantidade de íons de prata (20 mg/L) liberados nas diferentes amostras, com ou sem ácido húmico $(20 \mathrm{mg} / \mathrm{L})$ às $0,24,48$ e 96 horas após o preparo. Para as amostras de AgNP suspendidas em água SIST e REC sem AH não foi observada uma correlação tempo dependente na liberação de íons, enquanto que para as amostras de AgNP suspendidas em água SIST e REC, com presença de ácido húmico, a liberação de íons foi aumentando ao longo do tempo. Este comportamento (correlação tempo dependente) também foi observado para as amostras de AgNP suspendidas em água MQ na presença ou ausência de ácido húmico, sendo no entanto maior para as amostras de AgNP em presença de ácido húmico (AgNP AH MQ). Este comportamento ocorreu de maneira inversa para as AgNP suspendidas em água SIST, onde as nanopartículas com a presença do AH liberaram maior quantidade de íons. Adicionalmente foi observado que para as AgNP suspendidas em água SIST sem AH, a partir de 24 horas, a concentração de íons de prata liberados decresce. Para as AgNP 
suspendidas em água REC foi observado um comportamento similar, mas se começa a observar a diminuição na concentração de íons às 96 horas após o preparo das nanopartículas.
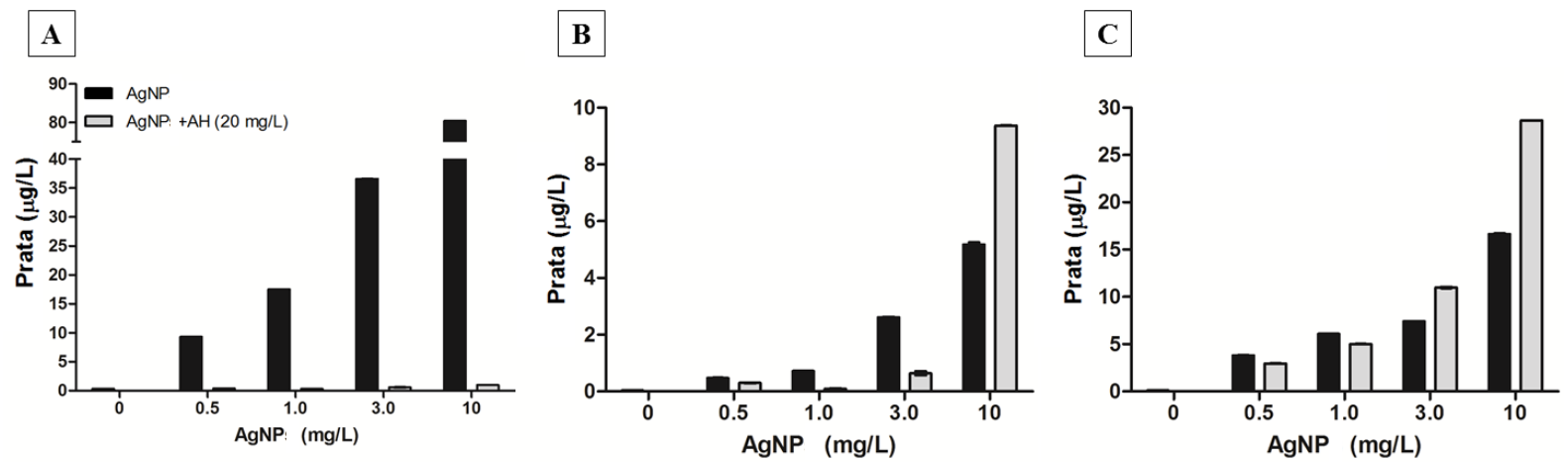

Figura 41. Quantificação dos íons de prata liberados na água a partir de diferentes concentrações de AgNP (0; 0,5; 1,0; 3,0 e $10 \mathrm{mg} / \mathrm{L}$ ) com e sem a presença de AH (20 mg/L), após 96 horas da sonicação. AgNP suspendidas em água MQ (A), água SIST (B) e água REC (C). As análises foram realizadas por ICP-MS. Os dados representam a Média \pm Desvio Padrão.

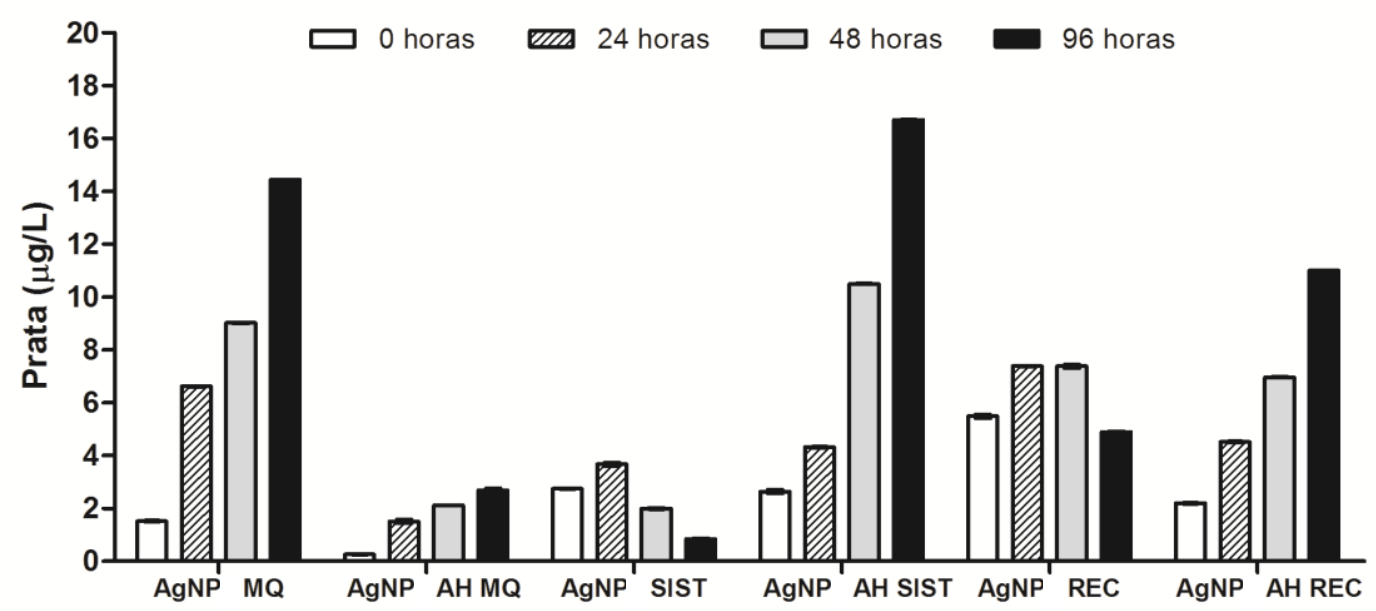

Figura 42. Quantificação dos íons de prata liberados na água a partir da concentração de 20 mg/L de AgNP, com e sem a presença de AH (20 mg/L), nos tempos 0, 24, 48 e 96 horas após exposição. As AgNP foram suspendidas em água MQ, água REC e água SIST. As análises foram realizadas por ICP-MS. Os dados representam a Média \pm Desvio Padrão. 
5.7. AVALIAÇÃO DA TOXICIDADE AGUDA, EM ZEBRAFISH, DE NANOPARTÍCULAS DE PRATA SUSPENSAS EM ÁGUA SIST, COM E SEM A PRESENÇA DE ÁCIDO HÚMICO

\subsubsection{Avaliação da toxicidade no desenvolvimento embrio-larval do zebrafish}

Os embriões expostos às AgNP, com e sem a presença de $\mathrm{AH}$, nas condições experimentais já especificadas mostraram toxicidade correlacionada com as concentrações avaliadas (relação concentração-resposta) (Figuras 43 e 44A). A CL50 encontrada para os subgrupos expostos a AgNP foi de 1,19 mg/L, e para os subgrupos expostos a AgNP+AH foi de 3,56 mg/L (Figura 43). A mortalidade foi observada principalmente às 24 horas de exposição para os subgrupos expostos a concentrações menores do que a CL50 para AgNP, e às 72 horas de exposição para os subgrupos expostos a concentrações maiores do que a CL50 para AgNP+AH. Nos subgrupos controle (0 e $20 \mathrm{mg} / \mathrm{L} \mathrm{AH}$ ) foi observado que a mortalidade foi <5\% (Figura 44A) ao longo do período experimental.

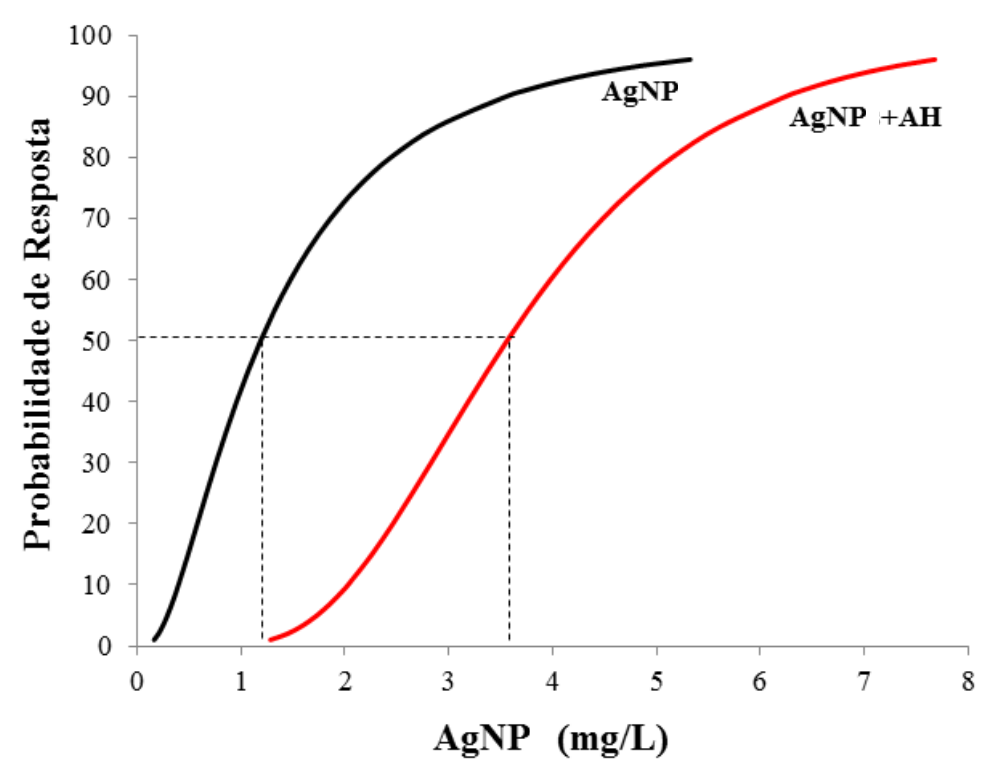

Figura 43. Concentração letal 50\% (CL50) das AgNP e das AgNP na presença de AH (20 mg/L) em 96 horas após fertilização. CL50: AgNP=1,19mg/L; AgNP+AH=3,56mg/L. Teste Probit (SPSS).

As larvas expostas a AgNP mostraram diferenças estatisticamente significativas nas concentrações testadas e para os diferentes parâmetros considerados nesta avaliação. Desta maneira, as larvas expostas apenas a AgNP mostraram diferenças 
estatisticamente significativas na viabilidade dos ovos (Figura 44A), batimento cardíaco (Figura 44C), e alterações do equilíbrio (Figura 44D) quando comparados com o grupo controle, a partir da concentração de $0,25 \mathrm{mg} / \mathrm{L}$ de AgNP. 0 atraso na eclosão (Figura 44B), edema generalizado (Figura 44F), atraso na absorção do saco vitelínico (Figura 44E), anormalidades no saco vitelínico (Figuras 45B e F, 46B) e malformações tais como microcefalia (Figura 44I) foram estatisticamente diferentes a partir da concentração de $1 \mathrm{mg} / \mathrm{L}$ de AgNP e a partir de 0,5 mg/L para o edema cardíaco. A frequência do total de organismos malformados (Figura $44 \mathrm{H}$ ) foi alta, mas não estatisticamente significativa quando comparado com o grupo controle. Entre as outras anormalidades encontradas sem significância estatística estão malformações na cauda (Figuras 45C e G) e na coluna (Figuras 45F e G; Figuras 46C-E; Figuras 47B).

Por outro lado, os organismos expostos às AgNP+AH mostraram diferenças estatisticamente significativas apenas a partir da concentração de $2 \mathrm{mg} / \mathrm{L}$ de AgNP+AH para o batimento cardíaco (Figura 44C) e atraso na absorção do saco vitelínico (Figura 44E); a partir de 3,0 mg/L AgNP+AH para coagulação (Figura 44A), alteração no equilíbrio (Figura 44D) e total de malformados (Figura 44H); a partir de 4,75 mg/L AgNP+AH para microcefalia (Figura 44I), e a partir de 6,5 mg/L AgNP+AH para atraso na eclosão (Figura 44B) e edema generalizado (Figura 44F). Os organismos expostos apenas ao AH apresentaram, como única anormalidade, edema cardíaco (Figura 44G), o qual foi estatisticamente significativo.

A coagulação dos ovos foi observada, principalmente, às 24 horas para os grupos expostos à AgNP e às 72 horas para os grupos expostos às AgNP+AH. Adicionalmente, a eclosão foi observada no grupo controle às 48 horas enquanto que para os grupos expostos aconteceu ao redor das 72 horas após exposição, indicando um atraso neste processo natural para os organismos expostos tanto às AgNP como às AgNP+AH.

0 edema generalizado foi observado principalmente entre as 72 e 96 horas de exposição às AgNP, e entre as 48 e 96 horas após exposição às AgNP+AH.

Com os resultados obtidos, foi possível observar que as AgNP causaram efeitos tóxicos em concentrações menores do que a CL50 calculada $(1,19 \mathrm{mg} / \mathrm{L})$, pois foram encontradas alterações (estatisticamente significativas) nos organismos expostos a 
partir de $1 \mathrm{mg} / \mathrm{L}$. Em contraste, os organismos expostos as AgNP com a presença de AH essas alterações foram estatisticamente significativas principalmente para os organismos expostos a concentrações maiores do que a CL50 calculada (3,56 mg/L) para este grupo experimental. Nas Tabelas 8 e 9 estão resumidos os dados descritos anteriormente, indicando com " $\mathrm{x}$ " a partir de qual concentração foram encontradas as diferentes alterações. É importante mencionar que se observou formação de precipitado no fundo das placas de cultura (Figuras 47B, C) e também deposição na superfície do corion dos embriões (Figura 47D). Macroscopicamente foi possível observar os precipitados formados, provavelmente, pela agregação das AgNP e/ou AgNP+AH ao longo do experimento.

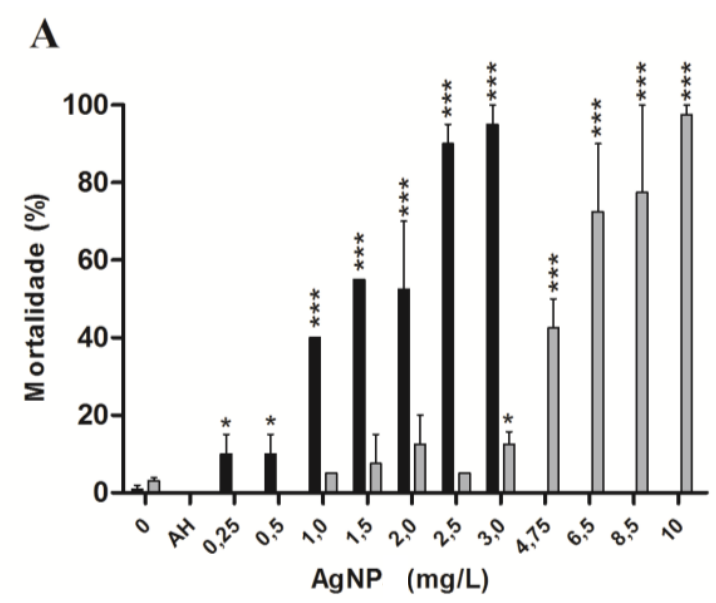

B

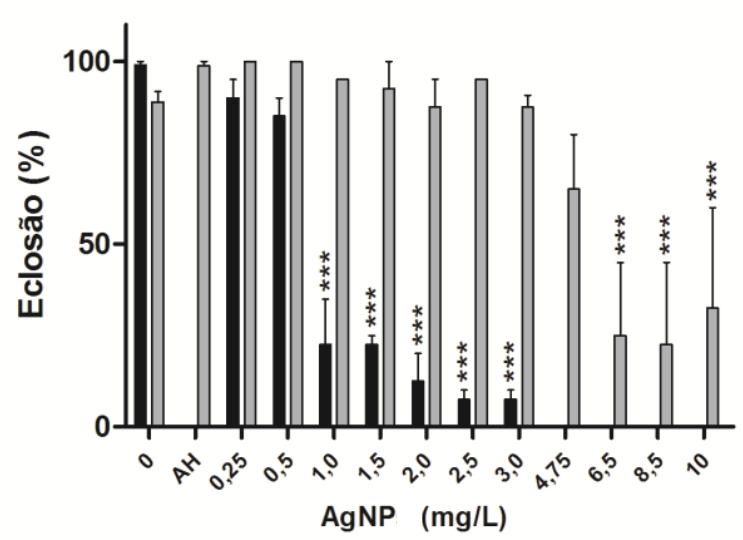

C

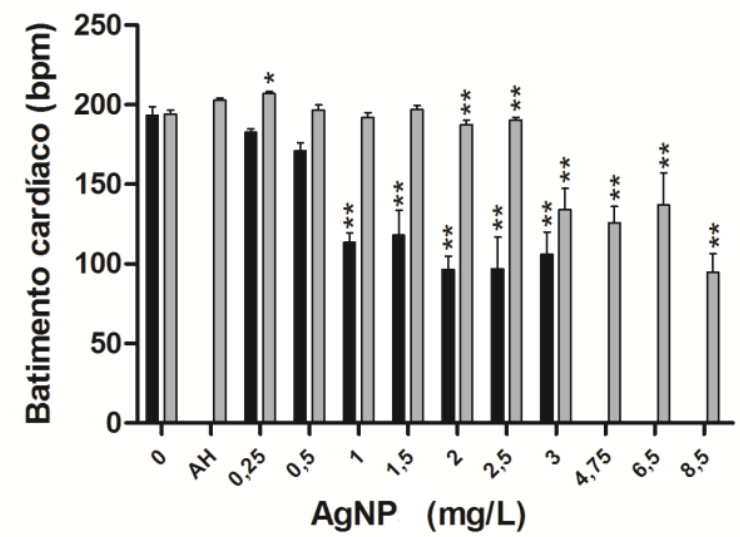


D

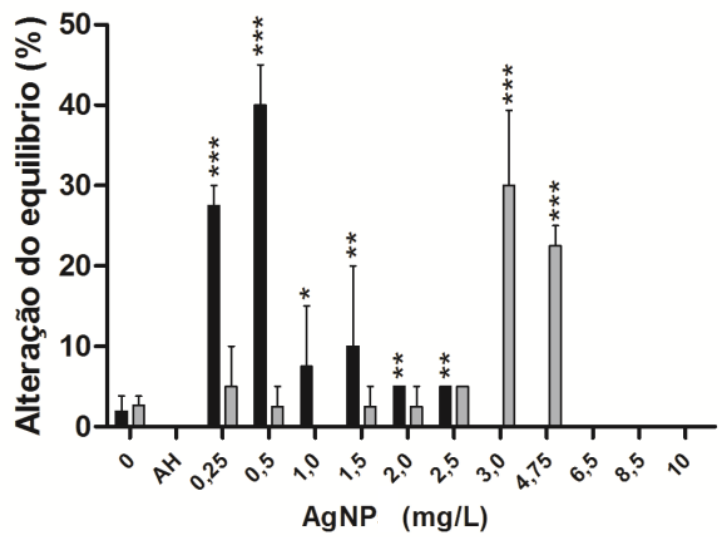

$\mathbf{F}$

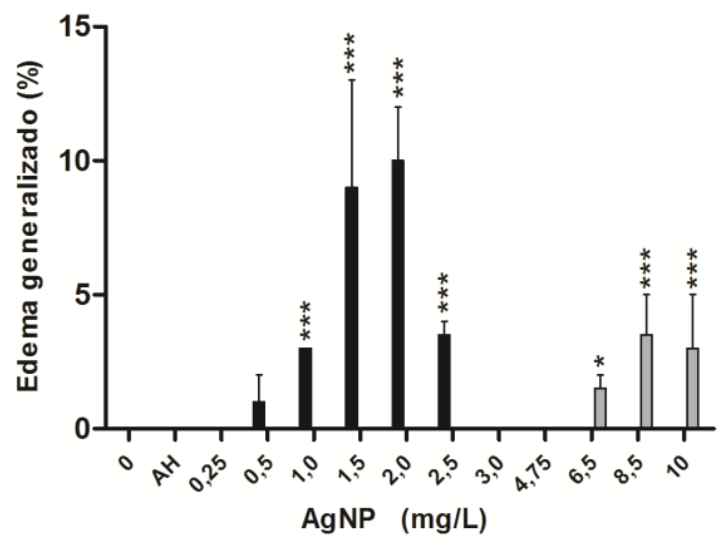

$\mathbf{H}$

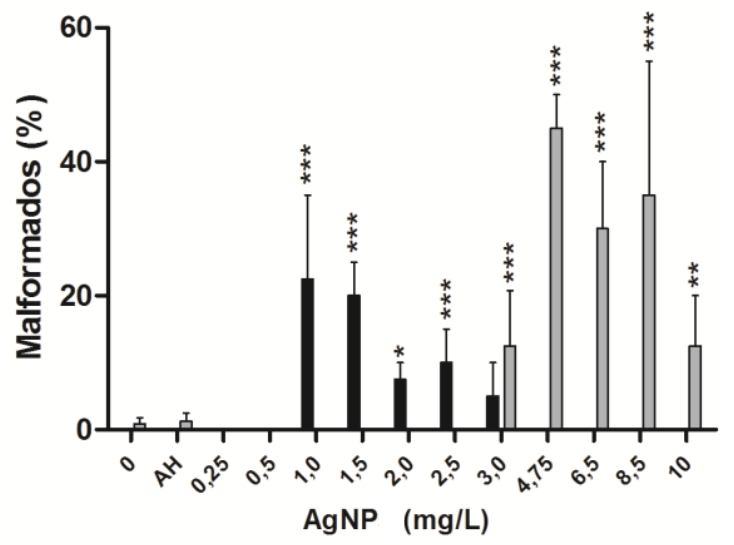

$\mathbf{E}$

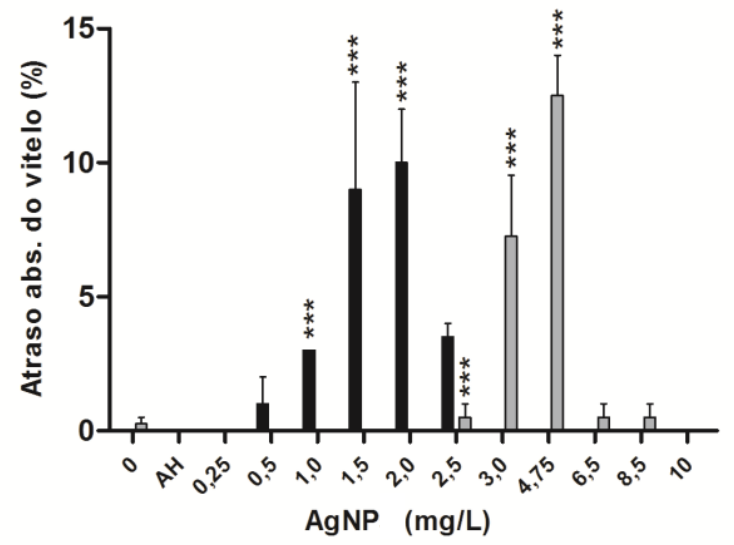

G

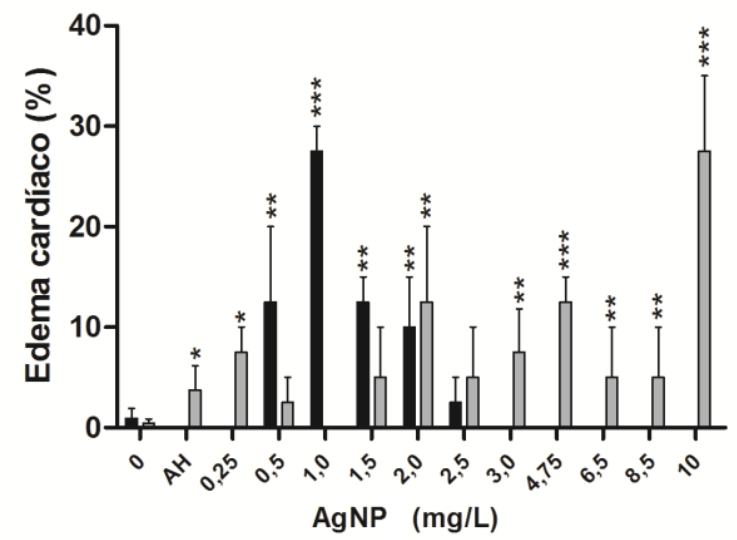

I

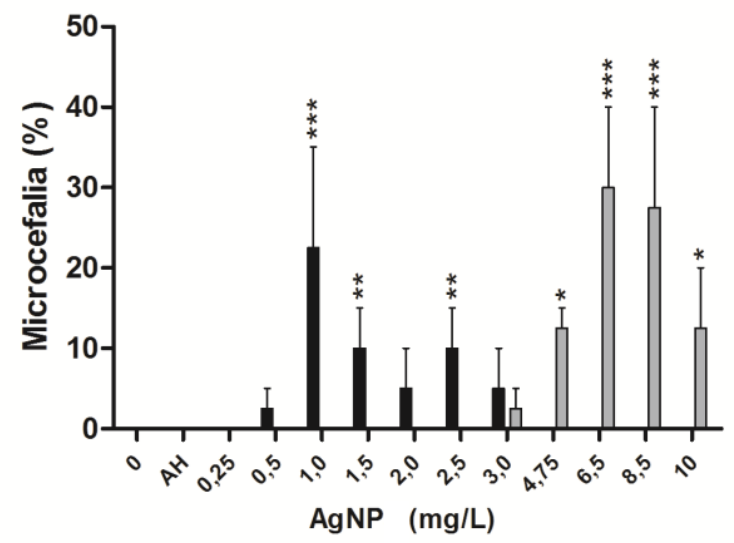

Figura 44. Avaliação do desenvolvimento embrio-larval durante 96 horas da fertilização mediante a exposição de AgNP (barras pretas), $\mathrm{AH}$ e AgNP+AH (barras cinzas). As figuras ilustram as comparações entre os diferentes parâmetros considerados na avaliação do desenvolvimento embrio-larval: (A) mortalidade, (B) eclosão, (C) batimento cardíaco, (D) alteração do equilibrio, (E) atraso na absorção do saco vitelínico, (F) edema generalizado, (G) edema cardíaco, (H) total de malformados, (I) microcefalia. Os dados estão representados pela Média \pm Desvio Padrão, $n=40$. Os asteriscos indicam a significância estatística quando comparados os grupos expostos com o grupo controle: $\mathrm{p} \leq 0,05(*) ; p \leq 0,01\left(^{* *}\right)$ e $p \leq 0,001\left({ }^{* *}\right)$. 0 s dados foram analisados utiliando o Teste exato de Fisher. 

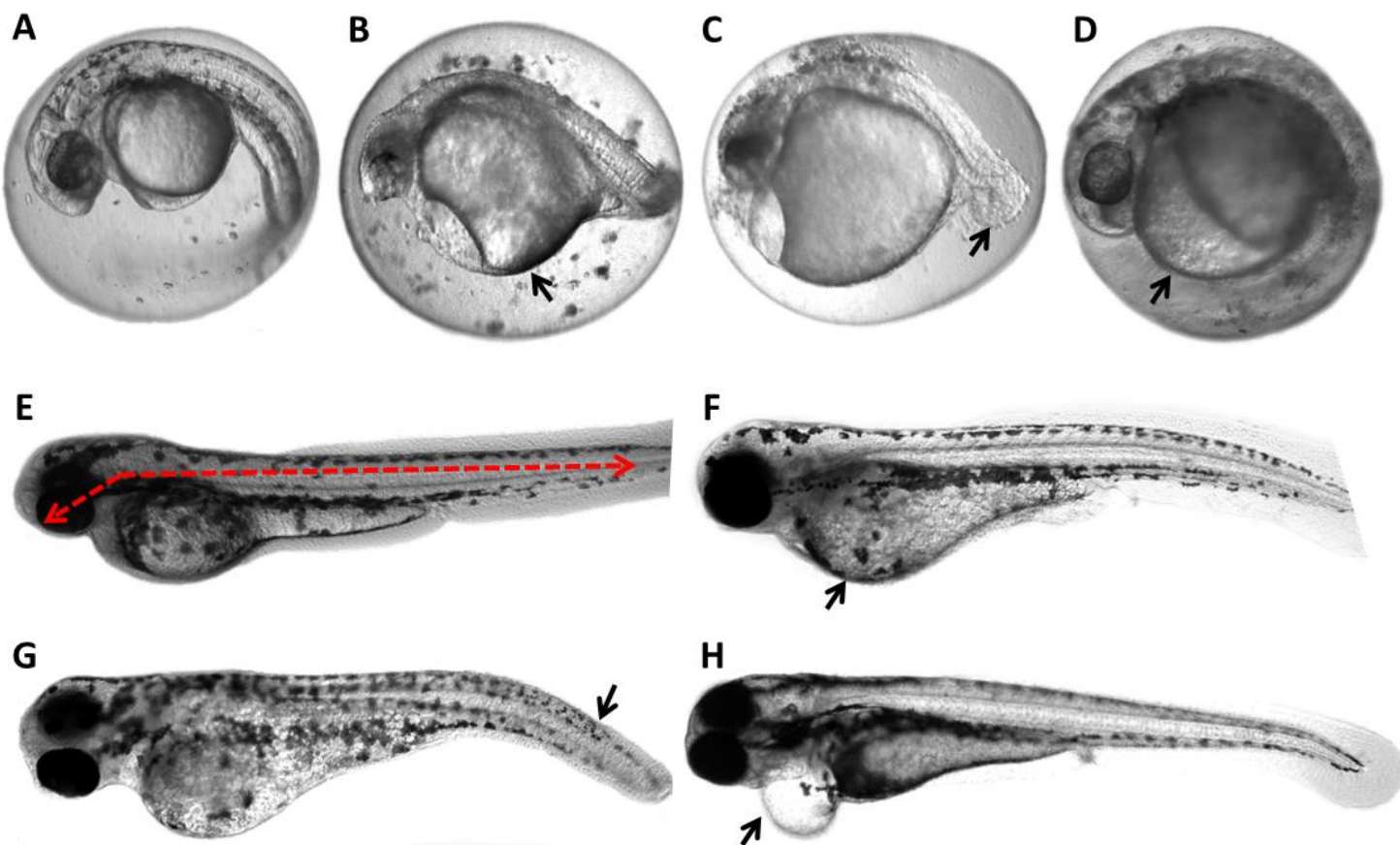

Figura 45. Imagens representativas dos organismos expostos durante 96 horas às AgNP, com e sem a presença de AH. A-D correspondem aos embriões e E-H às larvas. (A, E) organismos controle, (B, C, D, F, G e H) expostos. As setas indicam: (B, F) atraso na absorção do saco vitelino, (C, G) malformação da cauda e (D, H) edema cardíaco. O parâmetro normal pro ângulo da cabeça-cauda nas larvas está indicado pelas setas vermelhas pontilhadas. 


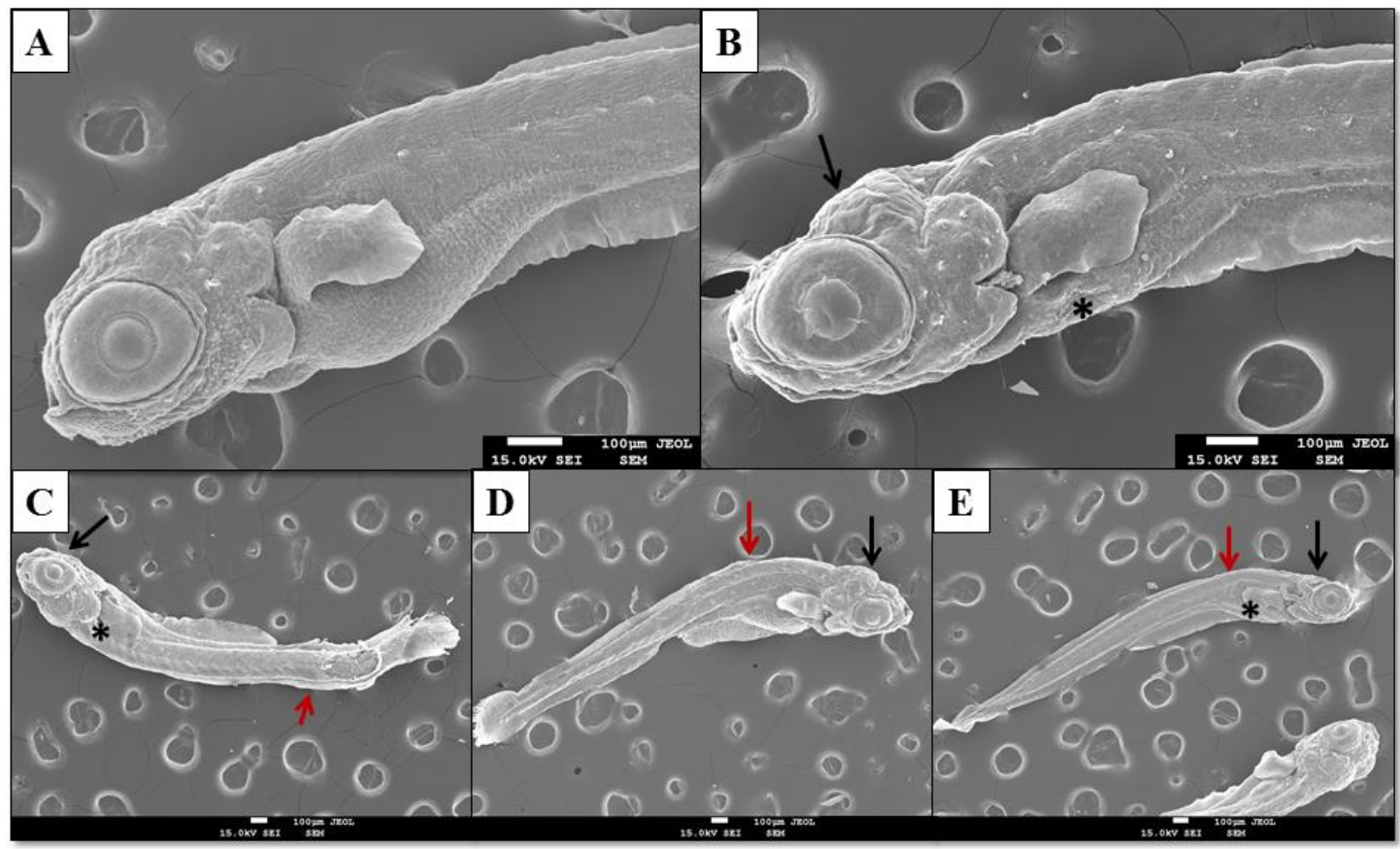

Figura 46. Micrografias eletrônicas de varredura de organismos expostos às AgNP, com e sem a presença de aH, após 96 horas da fertilização. (A) larva do grupo controle e (B, C, D e E) dos grupos expostos. Mudanças na morfologia da cabeça (setas pretas) e do saco vitelino (asteriscos), e tipos de malformações na coluna (setas vermelhas) encontradas nos grupos expostos. As escalas de barras correspondem a $100 \mu \mathrm{m}$.

Tabela 8. Síntese dos resultados obtidos na avaliação do desenvolvimento embrio-larval durante 96 horas da fertilização mediante a exposição de AgNP (Figura 44).

\begin{tabular}{ccccccc}
\hline $\begin{array}{c}\text { AgNP } \\
\mathbf{m g} / \mathbf{L})\end{array}$ & Mortalidade & $\begin{array}{c}\text { Atraso na } \\
\text { eclosão }\end{array}$ & $\begin{array}{c}\text { Edema } \\
\text { cardíaco }\end{array}$ & Bradicardia & $\begin{array}{c}\text { Total de } \\
\text { malformados }\end{array}$ & $\begin{array}{c}\text { Perda do } \\
\text { equilíbrio }\end{array}$ \\
\hline $\mathbf{0}$ & - & - & - & - & - & - \\
\hline $\mathbf{0 , 2 5}$ & - & - & - & - & - & - \\
\hline $\mathbf{0 , 5}$ & - & - & $X$ & $X$ & - & $X$ \\
\hline $\mathbf{1 , 0}$ & $\mathrm{X}$ & $\mathrm{X}$ & $\mathrm{X}$ & $\mathrm{X}$ & $\mathrm{X}$ & $\mathrm{X}$ \\
\hline $\mathbf{1 , 5}$ & $\mathrm{X}$ & $\mathrm{X}$ & $\mathrm{X}$ & $\mathrm{X}$ & $\mathrm{X}$ & $\mathrm{X}$ \\
\hline $\mathbf{2 , 0}$ & $\mathrm{X}$ & $\mathrm{X}$ & $\mathrm{X}$ & $\mathrm{X}$ & $\mathrm{X}$ & $\mathrm{X}$ \\
\hline $\mathbf{2 , 5}$ & $\mathrm{X}$ & $\mathrm{X}$ & $\mathrm{X}$ & $\mathrm{X}$ & $\mathrm{X}$ & $\mathrm{X}$ \\
\hline $\mathbf{3 , 0}$ & $\mathrm{X}$ & $\mathrm{X}$ & $\mathrm{X}$ & $\mathrm{X}$ & $\mathrm{X}$ & $\mathrm{X}$ \\
\hline $\mathrm{X}$ & & & & & \\
\hline
\end{tabular}

X: concentrações onde foram observadas as diferentes alterações. 
Tabela 9. Síntese dos resultados obtidos na avaliação do desenvolvimento embrio-larval durante 96 horas da fertilização mediante a exposição de AgNP+AH (Figura 44).

\begin{tabular}{ccccccc}
\hline $\begin{array}{c}\text { AgNP+AH } \\
(\mathbf{m g} / \mathrm{L})\end{array}$ & Mortalidade & $\begin{array}{c}\text { Atraso na } \\
\text { eclosão }\end{array}$ & $\begin{array}{c}\text { Edema } \\
\text { cardíaco }\end{array}$ & Bradicardia & $\begin{array}{c}\text { Total de } \\
\text { malformados }\end{array}$ & $\begin{array}{c}\text { Perda do } \\
\text { equilíbrio }\end{array}$ \\
\hline $\mathbf{0 - 2 , 5}$ & - & - & - & - & - & - \\
\hline $\mathbf{3 , 0}$ & - & - & - & $\mathrm{X}$ & $\mathrm{X}$ & $\mathrm{X}$ \\
\hline $\mathbf{4 , 7 5}$ & $\mathrm{X}$ & $\mathrm{X}$ & $\mathrm{X}$ & $\mathrm{X}$ & $\mathrm{X}$ & $\mathrm{X}$ \\
\hline $\mathbf{6 , 5}$ & $\mathrm{X}$ & $\mathrm{X}$ & $\mathrm{X}$ & $\mathrm{X}$ & $\mathrm{X}$ & $\mathrm{X}$ \\
\hline $\mathbf{8 , 5}$ & $\mathrm{X}$ & $\mathrm{X}$ & $\mathrm{X}$ & $\mathrm{X}$ & $\mathrm{X}$ & $\mathrm{X}$ \\
\hline $\mathbf{1 0}$ & $\mathrm{X}$ & $\mathrm{X}$ & $\mathrm{X}$ & $\mathrm{X}$ & $\mathrm{X}$ & $\mathrm{X}$ \\
\hline $\mathrm{X}$ & & &
\end{tabular}

X: concentrações onde foram observadas as diferentes alterações.

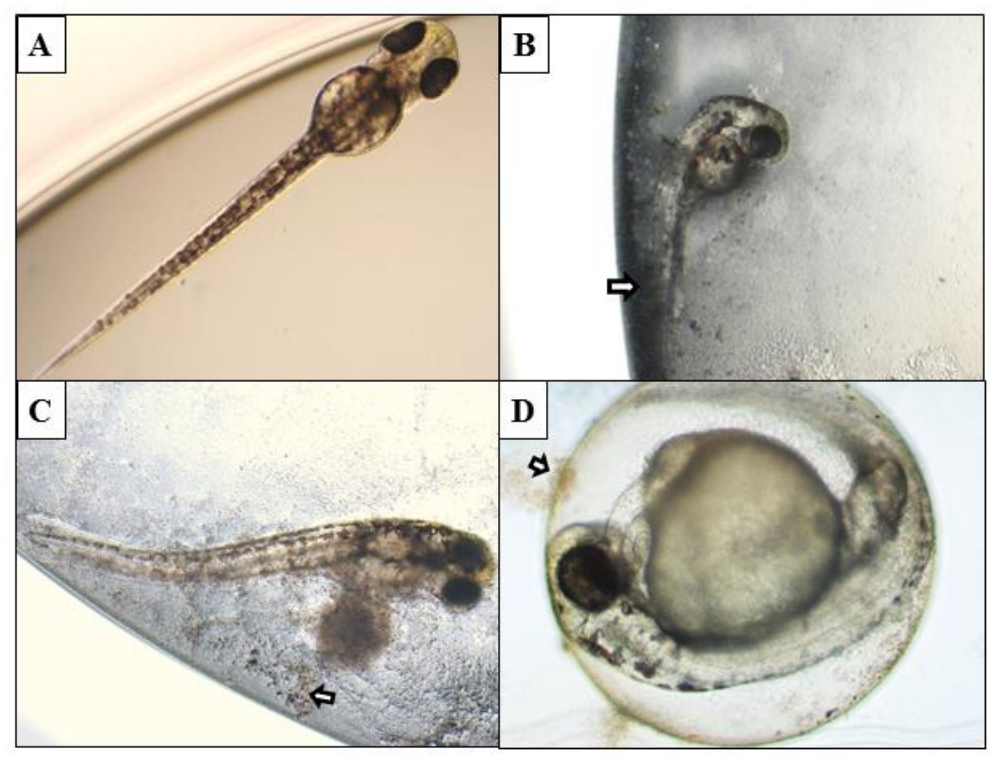

Figura 47. Imagens representativas dos organismos expostos a AgNP, AH, e AgNP+AH. Larvas pertencentes aos subgrupos: controle (A), AgNP (B), AgNP+AH (C) e AH (D). As setas indicam a precipitação dos materiais testados, no fundo da placa de cultura (B e C) e na superfície do corion (D).

\subsubsection{Parâmetros Físico-Químicos da Água do Sistema Contendo Nanopartículas de Prata com e sem a Presença de Ácido Húmico}

No Anexo B estão representadas as medidas dos parâmetros físico-químicos da água dos diferentes grupos expostos às AgNP, com e sem a presença de AH. Nos diferentes experimentos não foram observadas alterações na concentração de nitritos 
(ppm), amônia (ppm), dureza total, $\mathrm{pH}$, condutividade ou temperatura entre os subgrupos experimentais expostos à AgNP. Os parâmetros físico-químicos encontrados estão dentro dos parâmetros estabelecidos no guideline da OECD 273 "Fish Embryo Acute Toxicity Test (FET)".

\subsubsection{Quantificação da Prata nas Larvas de Zebrafish}

Após 96 horas de exposição tanto às AgNP como às AgNP+AH os resultados mostraram que houve incorporação da prata em todos os organismos. Essa incorporação nos embriões (Figura 48) aumentou na medida em que se aumentou a concentração de AgNP, em ambos os grupos experimentais, e quando comparadas com o grupo controle ( $0 \mathrm{mg} / \mathrm{L} \mathrm{AgNP}$ ), as diferenças foram estatisticamente significativas $(\mathrm{p}<0,05)$, exceto para o grupo exposto à concentração de $0,5 \mathrm{mg} / \mathrm{L} \mathrm{AgNP}+\mathrm{AH}$. Em todas as concentrações $(0,5 ; 1,0 ; 1,5$ e 3,0 mg/L) observou-se que os organismos expostos à AgNP incorporaram quantidades maiores de prata do que os grupos expostos a $\mathrm{AgNP}+\mathrm{AH}$.

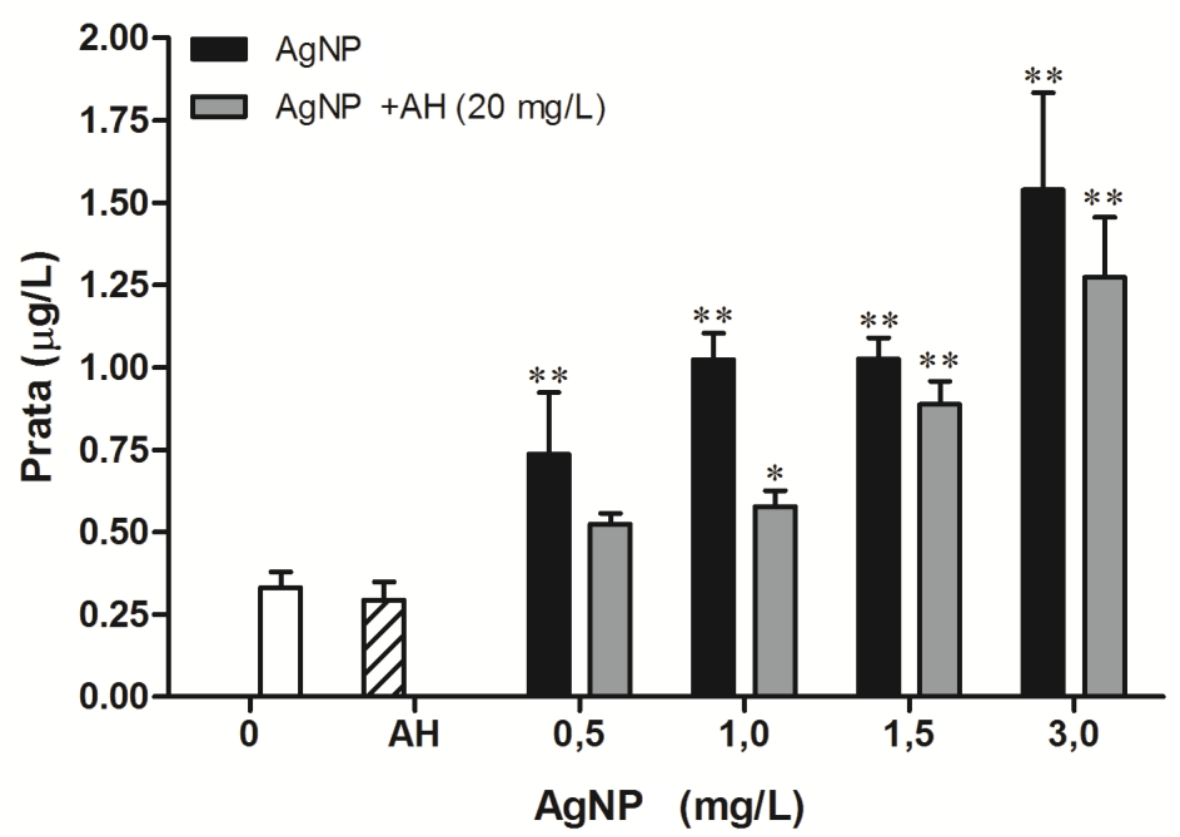

Figura 48. Prata incorporada $(\mu \mathrm{g} / \mathrm{L})$ nos organismos durante 96 horas de exposição às AgNP, com e sem a presença de AH. Os dados representam a Média \pm Desvio Padrão das amostras analisadas. Os asteriscos indicam a significância estatística quando comparados os grupos expostos com o grupo controle: $p \leq 0,05\left(^{*}\right)$; $p \leq 0,01\left(^{* *}\right)$ e $p \leq 0,001\left(^{* * *}\right)$. Os dados foram analisados utiliando o Teste de Dunnett (ANOVA). 


\subsubsection{Avaliação da toxicidade em peixes zebrafish adultos}

Para a determinação da CL50 das AgNP, com e sem a presença de AH, os peixes

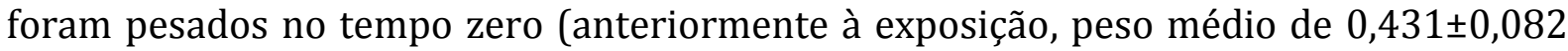

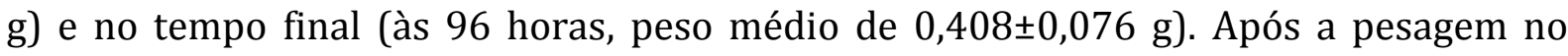
tempo zero, os peixes foram distribuídos aleatoriamente entre os subgrupos experimentais descritos no item 4.9.3.2 de Materiais e Métodos (Avaliação da toxicidade em zebrafish adultos). Durante o tempo de exposição os peixes foram observados para se avaliar os sinais clínicos decorrentes da exposição, encontrando que entre os subgrupos experimentais 0; $10 \mathrm{mg} / \mathrm{L}$ de AgNP (com e sem AH) e $20 \mathrm{mg} / \mathrm{L}$ de AH não foram observadas ocorrência de morbidade, alterações macroscópicas, alterações comportamentais e outras alterações clínicas. Entretanto, os subgrupos tratados com AgNP sem AH, foi observado que a partir da concentração de $20 \mathrm{mg} / \mathrm{L}$ de AgNP a mortalidade começou a aumentar assim como a ocorrência de pelo menos três das alterações macroscópicas avaliadas (Tabela 10). No entanto, nos subgrupos tratados com AgNP na presença de AH (Tabela 11), observou-se que a ocorrência de alterações macroscópicas diminuíram quando comparados com os subgrupos tratados só com AgNP, mesmo nas maiores concentrações. É importante mencionar que a alteração macroscópica mais frequente entre todos os subgrupos tratados (AgNP, com e sem $\mathrm{AH}$ ) foi o salto, o qual foi observado durante as primeiras 4 horas de exposição. Por outro lado, não foram observados sinais de comportamento agressivo ou alterações na cor da pele dos organismos de todos os grupos. Durante as primeiras 8 horas de exposição, os peixes que sobreviveram permaneceram no fundo do aquário, mas depois de 24 horas de exposição, não houve diferenças visíveis no comportamento entre o controle e os subgrupos expostos.

Baseado nos dados de mortalidade foi possível a determinação da concentração letal média (CL50), estimada em 25 e 40,56 mg/L de AgNP para os grupos expostos a AgNP e AgNP+AH, respectivamente (Figura 49). Os valores foram calculados para peixes adultos de Danio rerio expostos em meio estático durante 96 horas. 
Tabela 10. Ocorrência de mortalidade e sinais clínicos observados nos peixes adultos $(n=14)$ expostos às AgNP.

\begin{tabular}{ccccccc}
\hline $\begin{array}{c}\text { AgNP } \\
(\mathbf{m g} / \mathrm{L})\end{array}$ & $\begin{array}{c}\text { Mortalidade } \\
\text { No de individuos }\end{array}$ & $\begin{array}{c}\text { Perda do } \\
\text { equilíbrio }\end{array}$ & $\begin{array}{c}\text { Natação } \\
\text { superficial }\end{array}$ & $\begin{array}{c}\text { Natação } \\
\text { errática e } \\
\text { circular }\end{array}$ & $\begin{array}{c}\text { Salto } \\
\text { Produção de } \\
\text { muco }\end{array}$ \\
\hline $\mathbf{0}$ & - & - & - & - & - & - \\
branquial
\end{tabular}

X: grupos onde foram observadas as diferentes alterações.

Tabela 11. Ocorrência de mortalidade e sinais clínicos observados nos peixes adultos $(n=14)$ expostos ao $\mathrm{AH}$ e às $\mathrm{AgNP}+\mathrm{AH}$.

\begin{tabular}{ccccccc}
\hline $\begin{array}{c}\text { AH, AgNP+AH } \\
\text { (mg/L AgNP) }\end{array}$ & $\begin{array}{c}\text { Mortalidade } \\
\text { No de individuos }\end{array}$ & $\begin{array}{c}\text { Perda do } \\
\text { equilíbrio }\end{array}$ & $\begin{array}{c}\text { Natação } \\
\text { superficial }\end{array}$ & $\begin{array}{c}\text { Natação } \\
\text { errática e } \\
\text { circular }\end{array}$ & $\begin{array}{c}\text { Salto } \\
\text { muco }\end{array}$ & $\begin{array}{c}\text { Próão de } \\
\text { branquial }\end{array}$ \\
\hline $\mathbf{A H}$ & - & - & - & - & - & - \\
\hline $\mathbf{0}$ & - & - & - & - & - & - \\
\hline $\mathbf{1 0}$ & 1 & - & - & - & $\mathrm{X}$ & - \\
\hline $\mathbf{2 0}$ & 1 & - & - & - & $\mathrm{X}$ & - \\
\hline $\mathbf{3 0}$ & 3 & - & - & - & $\mathrm{X}$ & - \\
\hline $\mathbf{6 0}$ & 8 & - & - & $\mathrm{X}$ & $\mathrm{X}$ & - \\
\hline
\end{tabular}

$\mathrm{X}$ : grupos onde foram observadas as diferentes alterações. 


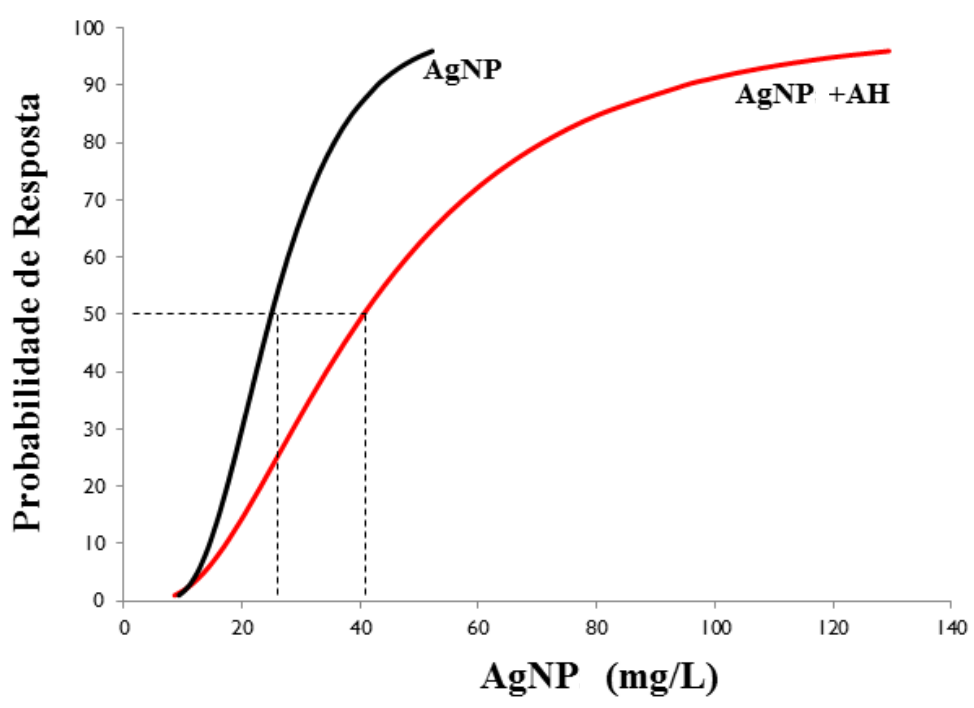

Figura 49. Concentração letal 50\% (CL50) das AgNP em adultos de zebrafish após exposição aguda (96 horas). CL50: AgNP=25,0 mg/L; AgNP+AH=40,56mg/L. Teste Probit (SPSS).

\subsubsection{Parâmetros Físico-Químicos da Água do Sistema Contendo Nanopartículas de Prata com e Sem a Presença de Ácido Húmico}

No Anexo B estão representadas as medidas dos parâmetros físico-químicos da água dos diferentes grupos expostos às AgNP, com e sem a presença de AH. Nos diferentes experimentos não foram observadas alterações na concentração de nitritos (ppm), amônia (ppm), dureza total, $\mathrm{pH}$, condutividade ou temperatura entre os subgrupos experimentais expostos à AgNP. Os parâmetros físico-químicos encontrados estão dentro dos parâmetros estabelecidos no guideline da OECD 203 "Fish, Acute Toxicity Test".

\subsubsection{Genotoxicidade e Mutagenicidade em Peixes Adultos}

Na Figura 50 estão representadas as porcentagens de fragmentação do DNA e a sua respectiva classificação segundo o tipo de dano encontrado nas células de peixes expostos a diferentes concentrações da AgNP, com e sem a presença de AH, após a realização do teste do cometa. As porcentagens correspondentes ao dano moderado (Figura 50A), elevado (Figura 50B) e total (Figura 50C) sugerem que a exposição às AgNP ou às AgNP+AH não induziram fragmentação no DNA do Danio rerio. Consequentemente, diferenças estatisticamente significativas não foram observadas 
entre os subgrupos de cada material-teste utilizados neste delineamento experimental, não estabelecendo uma relação concentração-resposta.

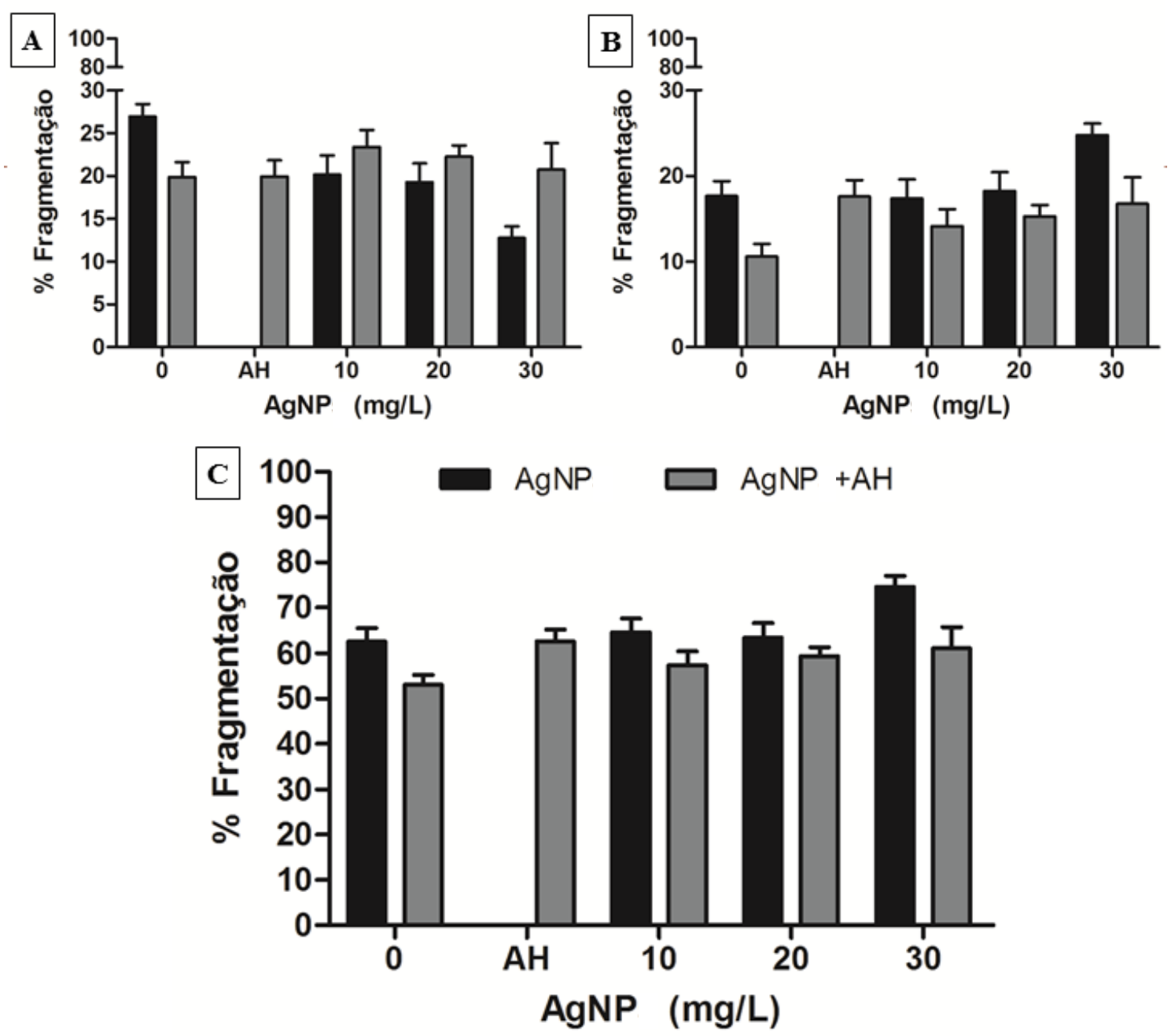

Figura 50. Fragmentação no DNA (\%) em eritrócitos de peixes expostos a AgNP com e sem a presença de AH. As figuras representam o dano moderado (A), dano elevado (B) e dano total (C) observado após 96 horas de exposição. Os dados representam a Média \pm Desvio Padrão ( $n=14)$. Foram realizadas comparações múltiplas utilizando o Teste de Tukey-Kramer (ANOVA). Diferenças significativas não foram observadas para todos os subgrupos expostos a AgNP, com e sem a presença de $\mathrm{AH}(\mathrm{p}>0,05)$.

A Tabela 12 representa as anormalidades nucleares e células com micronúcleos que foram observadas em eritrócitos de peixes dos subgrupos controle e tratados com AgNP ou AgNP+AH. Diferenças estatisticamente significativas não foram observadas para células micronucleadas, com brotos e "lobed". Entretanto, os organismos expostos a 
$30 \mathrm{mg} / \mathrm{L}$ de AgNP, $20 \mathrm{mg} / \mathrm{L}$ de AgNP+AH e $20 \mathrm{mg} / \mathrm{L}$ de AH apresentaram diferenças estatisticamente significativas quanto a presença de células binucleadas, células com núcleo "blebbed" e "notched", respectivamente.

Tabela 12. Micronúcleos e anormalidades nucleares observadas en eritrócitos de sangue periférico de peixes (Danio rerio) expostos a AgNP, com e sem a presença de AH.

\begin{tabular}{|c|c|c|c|c|c|c|c|}
\hline GRUPO & $\begin{array}{c}\text { AgNP } \\
(\mathrm{mg} / \mathrm{L})\end{array}$ & MN & BR & BN & BB & LB & NT \\
\hline \multirow{4}{*}{ AgNP } & $\mathbf{0}$ & $0.50 \pm 0.71$ & $1.00 \pm 1.14$ & 0 & $1.14 \pm 1.22$ & $0.50 \pm 0.64$ & $0.57 \pm 0.73$ \\
\hline & 10 & $1.08 \pm 1.04$ & $1.46 \pm 1.34$ & $0.08 \pm 0.14$ & $1.00 \pm 1.08$ & $0.31 \pm 0.47$ & $1.23 \pm 2.27$ \\
\hline & 20 & $0.67 \pm 0.89$ & $1.92 \pm 1.58$ & $0.08 \pm 0.14$ & $0.58 \pm 0.78$ & $0.08 \pm 0.14$ & $0.17 \pm 0.28$ \\
\hline & 30 & 0 & $1.75 \pm 0.75$ & $1.50 \pm 1.50^{* *}$ & $0.75 \pm 1.13$ & $0.25 \pm 0.38$ & $0.75 \pm 0.75$ \\
\hline \multirow{5}{*}{$\mathrm{AgNP}+\mathrm{AH}$} & $\mathbf{0}$ & $0.21 \pm 0.37$ & $1.07 \pm 0.68$ & 0 & 0 & $0.21 \pm 0.34$ & 0 \\
\hline & AH & $0.21 \pm 0.37$ & $1.43 \pm 1.06$ & 0 & $0.64 \pm 0.73$ & $0.57 \pm 0.73$ & $0.64 \pm 0.73^{*}$ \\
\hline & 10 & 0 & $0.54 \pm 0.75$ & 0 & $0.31 \pm 0.43$ & $0.31 \pm 0.43$ & $0.31 \pm 0.47$ \\
\hline & 20 & $0.15 \pm 0.28$ & $0.77 \pm 0.83$ & 0 & $0.77 \pm 0.71^{*}$ & $0.38 \pm 0.47$ & 0 \\
\hline & 30 & $0.11 \pm 0.20$ & $1.11 \pm 1.06$ & 0 & $0.56 \pm 0.74$ & $0.33 \pm 0.52$ & $0.33 \pm 0.59$ \\
\hline
\end{tabular}

Os datos representam a Média \pm Desvio Padrão ( $n=14)$ de eritrócitos micronucleados (MN), com brotos (BR), binucleados (BN), "blebbed" (BB), "lobed" (LB) e "notched" (NT). Foi utilizado o Teste Dunn (Kruskal-Wallis), onde os asteriscos indicam a significância estatística quando comparado o grupo controle com os grupos expostos: $p \leq 0,05\left(^{*}\right) ; p \leq 0,01\left(^{* *}\right)$ e $p \leq 0,001\left(^{* * *}\right)$.

\subsubsection{3. $\quad$ Avaliação Histopatológica}

As alterações histológicas encontradas nas brânquias dos organismos expostos às AgNP e AgNP+AH estão representadas nas Tabelas 13 e 14, respectivamente. Nas Tabelas 13 e 14 está descrito o total de organismos que apresentaram alterações histológicas, detalhando o tipo de alteração histológica e a sua respectiva classificação segundo o estádio em que foi observada. Adicionalmente, na Figura 51 estão ilustrados os índices patológicos totais $\left(\mathrm{T}_{\mathrm{G}}\right)$ das brânquias, nos quais foram observadas diferenças, estatisticamente significativas $(\mathrm{p} \leq 0,05)$, quando comparado o subgrupo controle com a 
concentração de $30 \mathrm{mg} / \mathrm{L}$ do grupo exposto a AgNP+AH. Entretanto, as alterações observadas nos organismos expostos a AgNP não foram estatisticamente significativas.

Tabela 13. Alterações histológicas encontradas nos peixes expostos durante 96 horas a AgNP.

\begin{tabular}{|c|c|c|c|c|c|}
\hline \multirow[b]{2}{*}{ ESTÁDIO } & \multirow[b]{2}{*}{ ALTERAÇÕES HISTOLÓGICAS } & \multicolumn{4}{|c|}{ GRUPOS } \\
\hline & & $\begin{array}{c}0 \text { mg/L } \\
(n=7)\end{array}$ & $\begin{array}{c}10 \mathrm{mg} / \mathrm{L} \\
(\mathrm{n}=5)\end{array}$ & $\begin{array}{c}20 \mathrm{mg} / \mathrm{L} \\
(\mathrm{n}=6)\end{array}$ & $\begin{array}{c}30 \mathbf{~ m g} / \mathbf{L} \\
(\mathrm{n}=7)\end{array}$ \\
\hline \multirow{4}{*}{ I } & Descolamento do epitélio lamelar & 0 & 3 & 3 & 3 \\
\hline & Hipertrofia epitélio lamelar & 0 & 2 & 3 & 3 \\
\hline & Hiperplasia células epitélio lamelar & 0 & 1 & 0 & 0 \\
\hline & Fusão lamelar & 0 & 1 & 0 & 0 \\
\hline \multirow{4}{*}{ II } & Hipertrofia das células de cloro & 0 & 0 & 0 & 2 \\
\hline & Hiperplasia de células mucosas & 0 & 0 & 0 & 0 \\
\hline & Hipertrofia de células mucosas & 0 & 0 & 0 & 0 \\
\hline & Edema lamelar & 0 & 0 & 0 & 0 \\
\hline \multirow[t]{2}{*}{ III } & Aneurisma lamelar & 1 & 1 & 0 & 1 \\
\hline & Total de alterados & 1 & 3 & 3 & 4 \\
\hline
\end{tabular}

Na tabela está descrito o número de peixes que apresentaram alterações histológicas.

Tabela 14. Alterações histológicas encontradas nos peixes expostos durante 96 horas a $\mathrm{AgNP}+\mathrm{AH}$.

\begin{tabular}{|c|c|c|c|c|c|c|}
\hline \multirow[b]{2}{*}{ ESTÁDIO } & \multirow[b]{2}{*}{ ALTERAÇÕES HISTOLÓGICAS } & \multicolumn{5}{|c|}{ GRUPOS } \\
\hline & & $\begin{array}{c}0 \mathrm{mg} / \mathrm{L} \\
(\mathrm{n}=8)\end{array}$ & $\begin{array}{c}\text { AH } \\
(n=8)\end{array}$ & $\begin{array}{c}10 \mathrm{mg} / \mathrm{L} \\
(\mathrm{n}=6)\end{array}$ & $\begin{array}{c}20 \mathrm{mg} / \mathrm{L} \\
(\mathrm{n}=8)\end{array}$ & $\begin{array}{c}30 \mathrm{mg} / \mathrm{L} \\
(\mathrm{n}=8)\end{array}$ \\
\hline \multirow{4}{*}{ I } & Descolamento do epitélio lamelar & 3 & 4 & 5 & 5 & 5 \\
\hline & Hipertrofia epitélio lamelar & 3 & 2 & 5 & 6 & 7 \\
\hline & Hiperplasia células epitélio lamelar & 0 & 0 & 0 & 1 & 1 \\
\hline & Fusão lamelar & 0 & 0 & 0 & 2 & 1 \\
\hline \multirow{4}{*}{ II } & Hipertrofia das células de cloro & 0 & 0 & 1 & 2 & 2 \\
\hline & Hiperplasia de células mucosas & 0 & 0 & 0 & 1 & 0 \\
\hline & Hipertrofia de células mucosas & 0 & 0 & 0 & 2 & 0 \\
\hline & Edema lamelar & 0 & 0 & 0 & 0 & 1 \\
\hline \multirow[t]{2}{*}{ III } & Aneurisma lamelar & 0 & 0 & 0 & 2 & 2 \\
\hline & Total de alterados & 3 & 4 & 5 & 7 & 7 \\
\hline
\end{tabular}

Na tabela está descrito o número de peixes que apresentaram alterações histológicas. 


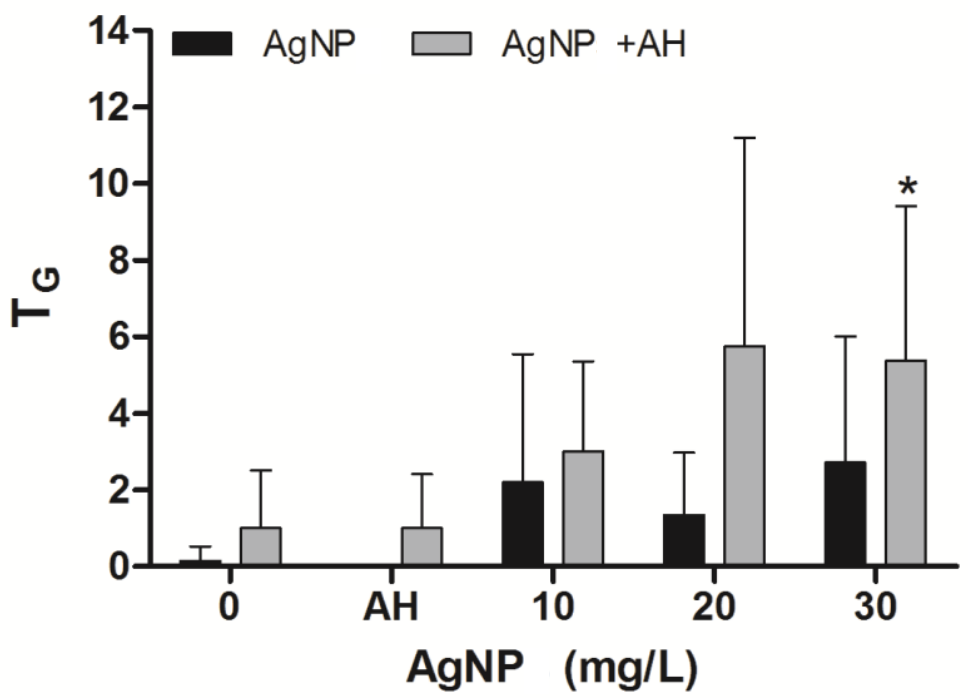

Figura 51. Índice histopatológico total para brânquia de Danio rerio. Foi utilizado o Teste Dunn (Kruskal-Wallis). Os asteriscos indicam a significância estatística quando comparado o grupo controle com os grupos expostos: $p \leq 0,05\left(^{*}\right) ; p \leq 0,01\left(^{* *}\right)$ e $p \leq 0,001\left({ }^{* * *}\right)$.

Na Figura 52 podemos observar imagens representativas das brânquias de Danio rerio, dos diferentes subgrupos obtidos por microscopia óptica. Na Figura 52A observase um corte longitudinal de filamentos branquiais, correspondentes a organismos sem alterações, mostrando a estrutura normal para este órgão. As alterações encontradas (Tabelas 13 e 14) nos organismos dos diferentes grupos de exposição são mostradas na Figura 52. Nessa figura é possível observar alterações como: hipertrofia do epitélio lamelar (Figura 52B), hipertrofia de células de cloro (Figura 52B), hipertrofia e hiperplasia de células mucosas (Figura 52C), edema lamelar (Figura 52C), hiperplasia das células do epitélio lamelar (Figura 52D), descolamento do epitélio lamelar (Figura 52D), aneurismas (Figuras 52D e E) e fusão lamelar (Figura 52F).

O fígado (Figuras 53A e B) e o intestino (Figuras 53C e D) dos organismos tratados com as AgNP e as AgNP+AH não apresentaram alterações histológicas; portanto, não foi realizado o calculo de $\mathrm{T}_{\mathrm{G}}$ para esses órgãos. Apesar disso, em todas as concentrações testadas, foi observada a presença dos materiais testados no lúmen intestinal (Figura 53D), indicando o seu consumo. A presença desses materiais no lúmen intestinal foi corroborada por Espectrometria de Energia Dispersiva de Raios X (EDX), cujos resultados estão apresentados na Figura 54. Os mapas e os espectros obtidos permitiram identificar a presença de prata, em todas as concentrações testadas, nos 
organismos expostos às AgNP (Figura 54B) e às AgNP+AH (Figura 54C).

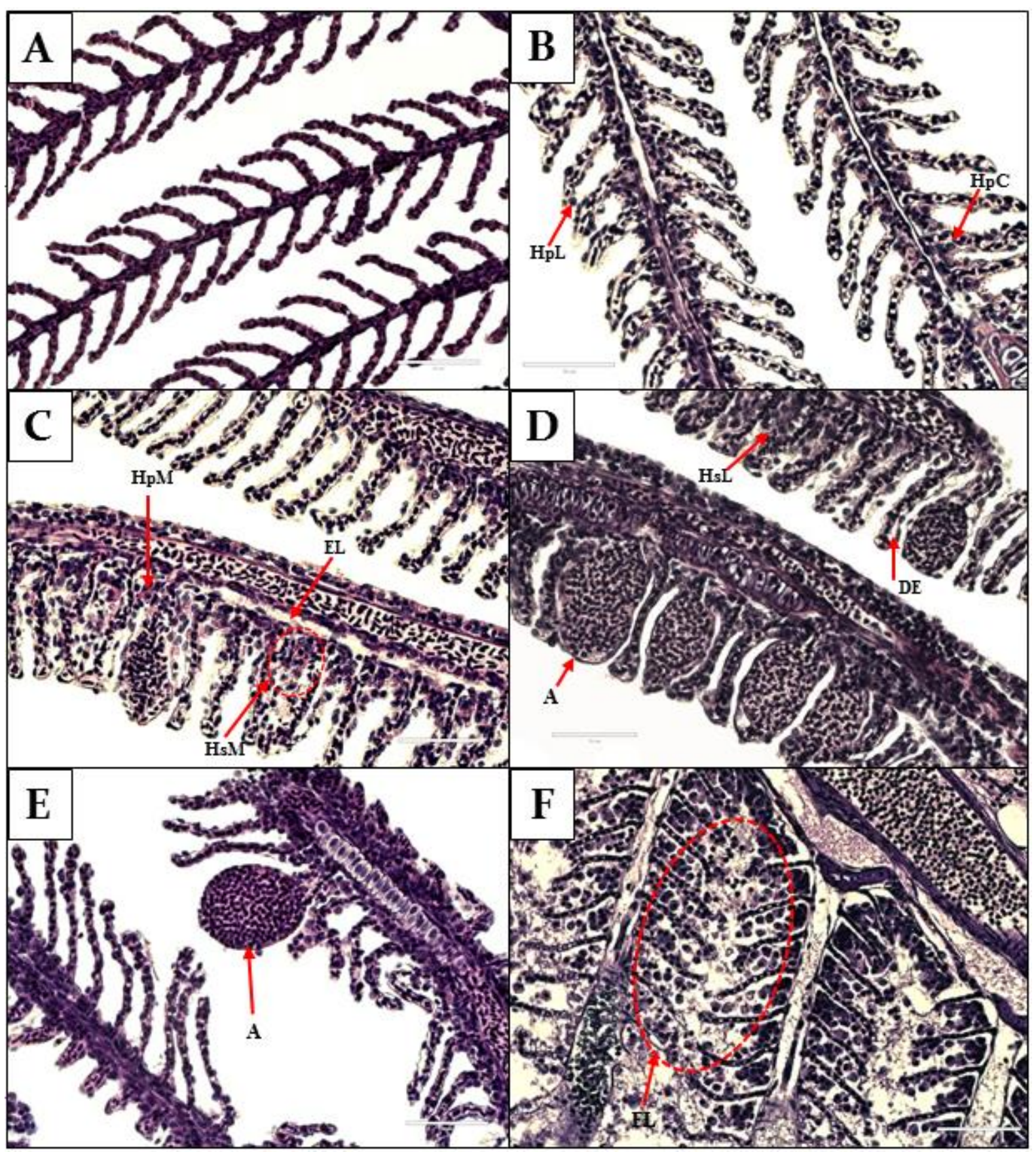

Figura 52. Cortes longitudinais de filamentos branquiais de Danio rerio. Micrografias representativas de brânquias de peixes que não apresentaram alterações histológicas (A). Micrografias representativas de filamentos branquiais onde se indicam com setas as alterações histopatológicas encontradas. Hipertrofia de células do epitélio lamelar (FpL), hipertrofia de células de cloreto $(\mathrm{HpC})$, hipertrofia de células mucosa ( $\mathrm{HpM})$, edema lamelar (EL), hiperplasia das células mucosas (HsM), hiperplasia das células do epitélio lamelar (HsL), descolamento do epitélio lamelar (DE), Aneurisma (A) e fusão lamelar (FL). Coloração H-E. As escalas de barras correspondem a $50 \mu \mathrm{m}$. 


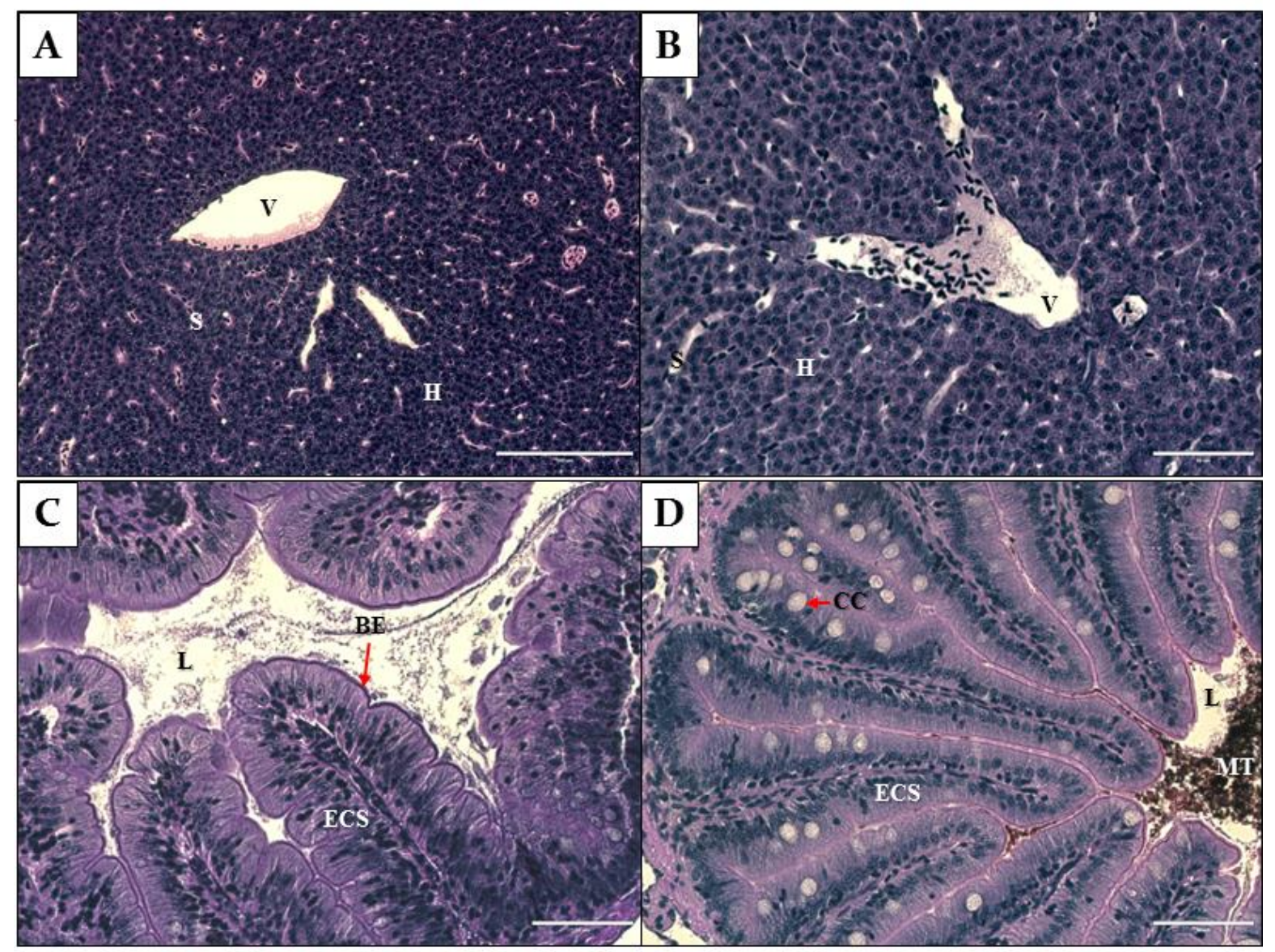

Figura 53. Micrografias representativas de fígado e intestino de Danio rerio de diferentes grupos experimentais. A figura A corresponde ao fígado de peixes do grupo controle, e a figura $\mathbf{B}$ corresponde ao fígado dos organismos tratados com AgNP ou AgNP+AH. Nas figuras A e B observam-se os hepatócitos (H), sinusóides (S) e a veia central (V). A micrografia C corresponde ao intestino dos peixes do grupo controle e a figura D representa o intestino dos organismos tratados com AgNP, AgNP+AH ou AH. Nas figuras C e D observam-se bordadura em escova (BE), epitélio colunar simples (ECS), lúmen (L) e as células caliciformes (CC). Os materiais testados (MT) foram observados no lúmen intestinal (D) dos peixes expostos a AgNP e AgNP+AH (D). Coloração H-E. As escalas de barras correspondem a $50 \mu \mathrm{m}$ (B, C e D) e $100 \mu \mathrm{m}$ (A). 


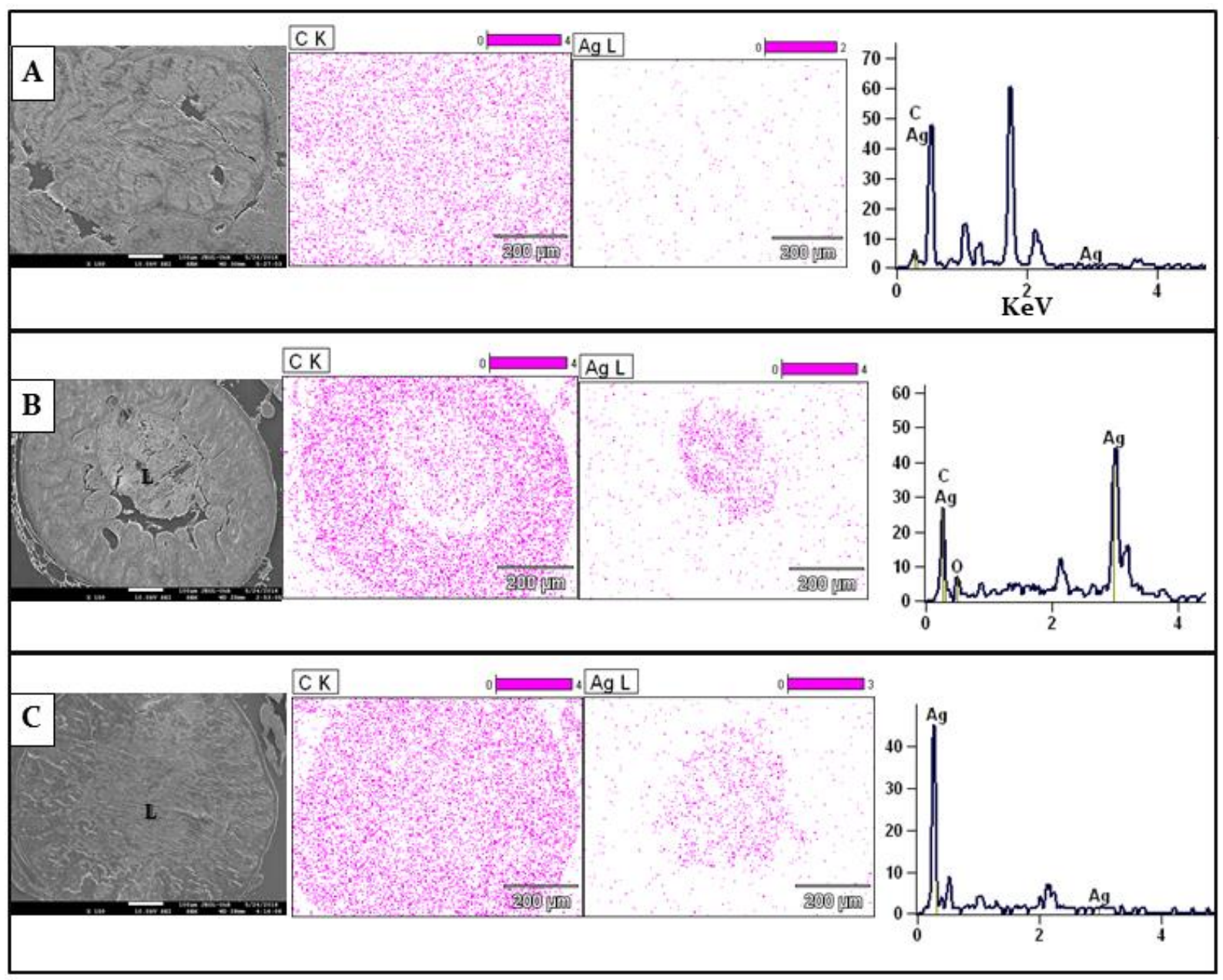

Figura 54. Micrografias eletrônicas de varredura de intestino de Danio rerio. Mapeamento do carbono (C) e prata (Ag) em cortes histológicos do intestino de peixes pertencentes ao grupo controle (A), AgNP (B) e AgNP+AH (C). Os mapas e os espectros foram obtidos por Espectrometria de Energia Dispersiva de Raios X (EDX). A intensidade da cor de cada elemento indica sua presença e localização na amostra. Foi observada a presença dos materiais testados no lúmen intestinal dos organismos expostos a AgNP e AgNP+AH.

\subsubsection{4. $\quad$ Avaliação da Acumulação/Biodistribuição das Nanopartículas de $\underline{\text { Prata em Zebrafish Adultos }}$}

0 peso e o comprimento médio dos peixes (Danio rerio) após exposição foi de 0,51 $\pm 0,10$ g e 3,11 $\pm 0,15 \mathrm{~cm}$, respectivamente, como determinado por ICP-MS. Na Figura 55 está apresentada a concentração de prata (ng Ag / mg órgão) no intestino (Figura 55A), fígado (Figura 55B), rim (Figura 55C), brânquia (Figura 55D) e músculo (Figura 55E) dos peixes zebrafish, expostos durante 96 horas a 0, 10 e $20 \mathrm{mg} / \mathrm{L}$ de AgNP; 0, 10, 
20 e $30 \mathrm{mg} / \mathrm{L}$ de AgNP+AH; e $20 \mathrm{mg} / \mathrm{L}$ de $\mathrm{AH}$. Nos grupos expostos às diferentes concentrações de AgNP foi observado que no intestino, fígado, rim e brânquias, a quantidade de prata presente aumentou em relação ao aumento da concentração de AgNP, mas quando comparados com o grupo controle encontrou-se significância estatística apenas no fígado, rim e brânquia na concentração de 20 mg/L AgNP. Embora no músculo não tenha sido observada uma relação (aumento) dependente da concentração, a incorporação de prata na concentração de 20 mg/L AgNP também foi estatisticamente significativa. Considerando os valores mais altos de prata quantificados em cada órgão analisado, nos grupos expostos às diferentes concentrações de AgNP, encontrou-se que o intestino foi o órgão que mais continha prata atingindo valores de 687,98 ng Ag / mg órgão; seguido pelo rim (147,11 ng Ag / mg órgão), o fígado (133,54 ng Ag / mg órgão), as brânquias (31,29 ng Ag / mg órgão) e o músculo (5,66 ng Ag / mg órgão).

Nos peixes zebrafish expostos às diferentes concentrações de AgNP+AH, foi observado que a quantidade de prata presente nestes órgãos não aumentou com o aumento da concentração de AgNP, mas quando comparados com o grupo controle encontrou-se significância estatística no intestino, fígado e músculo dos peixes expostos a $20 \mathrm{mg} / \mathrm{L} \mathrm{AgNP}+\mathrm{AH}$, e no fígado e brânquia dos expostos a $30 \mathrm{mg} / \mathrm{L} \mathrm{AgNP}+\mathrm{AH}$. Considerando os valores mais altos de prata quantificados em cada órgão analisado, nos grupos expostos às diferentes concentrações de $\mathrm{AgNP}+\mathrm{AH}$, encontrou-se que o intestino foi o órgão que mais continha prata atingindo valores de 470,86 ng $\mathrm{Ag} / \mathrm{mg}$ órgão; seguido pelo fígado (103,36 ng Ag / mg órgão), o rim (41,86 ng Ag / mg órgão), as brânquias (23,71 ng Ag / mg órgão), e o músculo (3,18 ng Ag / mg órgão).

Quando comparados os valores mais altos da prata quantificados nos diferentes órgãos avaliados dos peixes zebrafish expostos às AgNP e às $\mathrm{AgNP}+\mathrm{AH}$, observamos que a quantidade de prata nos órgãos dos peixes expostos às $\mathrm{AgNP}+\mathrm{AH}$ foi menor do que nos órgãos dos peixes expostos às AgNP. Quando calculadas as porcentagens de redução para cada órgão, considerando apenas os valores mais altos, o rim foi o órgão que apresentou maior porcentagem de redução (71,55\%), seguido pelas brânquias (54,89\%), músculo (43,82\%), intestino (31,56\%) e fígado $(22,56 \%)$. 

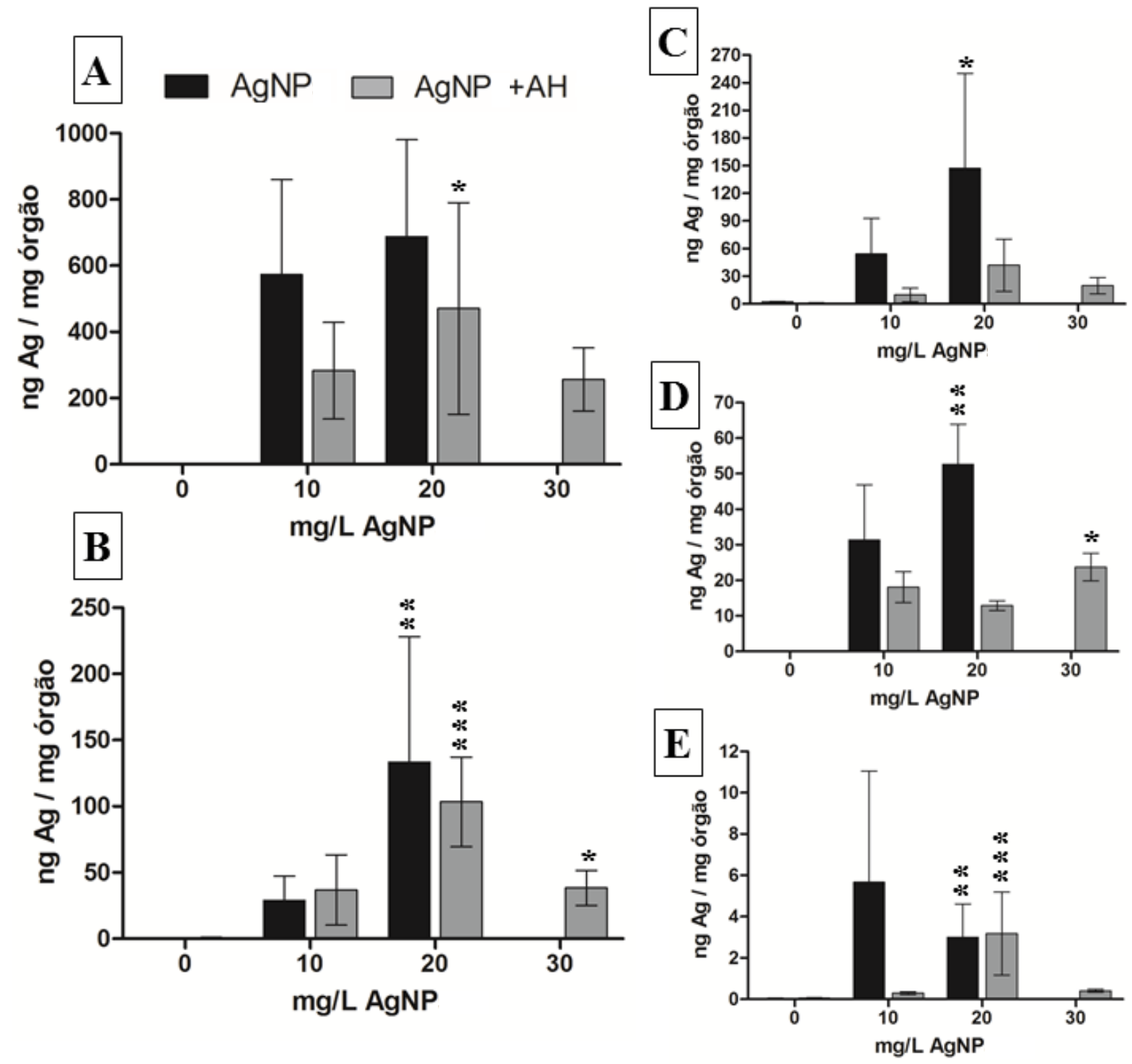

Figura 55. Concentração de Ag (ng Ag / mg órgão) no intestino (A), fígado (B), rim (C), brânquia (D) e músculo (E) dos peixes expostos durante 96 horas a 0, 10 e $20 \mathrm{mg} / \mathrm{L}$ de AgNP (barras pretas); 0, 10, 20 e $30 \mathrm{mg} / \mathrm{L}$ de AgNP na presença de $20 \mathrm{mg} / \mathrm{L}$ de ácido húmico (barras cinzas); e $20 \mathrm{mg} / \mathrm{L}$ de $\mathrm{AH}$. Os dados representam a Média \pm Desvio Padrão $(n=5)$. Foi utilizado o Teste Dunn (Kruskal-Wallis). Os asteriscos indicam a significância estatística quando comparado o grupo controle com os grupos expostos: $p \leq 0,05\left(^{*}\right) ; p \leq 0,01\left(^{* *}\right)$ e $p \leq 0,001(* *)$. 
6.

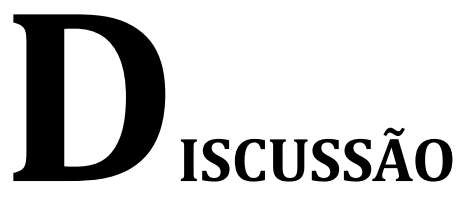

Hoje em dia existe um rápido desenvolvimento e produção de nanopartículas de prata para fabricação de diferentes produtos com propriedades antimicrobianas (BENN E WESTERHOFF, 2008), mas os impactos ambientais da liberação das AgNP de produtos comerciais não são ainda bem conhecidos. A quantidade e a forma em que os nanomateriais são liberados a partir de produtos de consumo devem ser determinadas para avaliar os riscos ambientais da nanotecnologia. Isto sugere a demanda de um maior conhecimento que permita aprimorar e regular tanto a fabricação quanto o uso dos nanomateriais.

É conhecido que os nanomateriais têm potencial para influenciar nas interações fisiológicas, desde o nível molecular até o nível sistemico (JEYARAJ et al., 2013; JOVANOVIĆ et al., 2014), devido as suas características físico-químicas, tornando os estudos relacionados com nanomateriais um tópico de pesquisa importante e interessante. Desta maneira, a utilização de técnicas robustas para a caracterização dos nanomateriais é fundamental para garantir a segurança das populações que possam interagir com estes.

Até certo ponto, a caracterização depende dos objetivos propostos em cada estudo. No entanto, há uma série de propriedades fundamentais que devem ser conhecidas para responder às perguntas de interesse. Autores como Oberdörster e colaboradores (2005 e 2005b), e Powers e colaboradores (2006), sugerem que uma completa caracterização das nanopartículas inclui o conhecimento do tamanho e a sua distribuição, formato, cristalinidade, porosidade, rugosidade, química do material, solubilidade, área de superfície, estado de dispersão, química de superfície, entre outras. 
Em nosso trabalho foram utilizadas técnicas como microscopia eletrônica de transmissão (MET), espalhamento dinâmico de luz (DLS), difração de raios X (DRX), espectroscopia no infravermelho com transformada de Fourier (FTIR), espectroscopia no infravermelho por refletância total atenuada com transformada de Fourier (ATRFTIR), espectroscopia de fotoelétrons excitados por raios X (XPS), entre outras, a fim de conhecer as características e comportamento das AgNP em diferentes sistemas aquosos.

É importante destacar que foram detectados traços de prata em todos os tipos de água utilizada nos experimentos, sendo estes $\leq 0,04 \mu \mathrm{g} / \mathrm{L}$. Os valores encontrados para a prata (Tabela 6) podem ser explicados pelo fato de que este é um elemento traço em águas doces e marinhas. Segundo os "Guidelines for Drinking-water Quality" da WHO (2003) e os critérios nacionais recomendados de qualidade da água da US EPA (2002), as concentrações médias de prata em águas naturais e o nível recomendado para a prata na água doce são 0,2-0,3 $\mu \mathrm{g} / \mathrm{L}$ e 3,2 $\mu \mathrm{g} / \mathrm{L}$, respectivamente.

Nos experimentos realizados com os três tipos de água (MQ, SIST e REC), as quais contém diferentes concentrações de sais, foi observado aumento no diâmetro hidrodinâmico das AgNP (Figura 27), e diminuição nos valores do potencial zeta (Figura 28) nessa ordem: REC $>$ SIST $>M Q$, provavelmente em função da maior concentração de sais presentes na primeira. Este comportamento também foi observado nos experimentos de estabilidade (Figuras 22 e 23) das AgNP em água MQ com diferentes forças iônicas $(0,02 ; 0,04$ e 0,08 $\mathrm{M}$ de $\mathrm{NaCl}$ ), onde o diâmetro hidrodinâmico (Figura 23A) e o potencial zeta (Figura 23B) das amostras que continham maior força iônica apresentaram tamanhos hidrodinâmicos maiores e diminuição no potencial zeta, indicando a formação de agregados nas amostras ao longo do tempo, como consequência da baixa repulsão na elevada força iônica (BIAN et al., 2011). Adicionalmente, essas mudanças no diâmetro hidrodinâmico e potencial zeta foram corroboradas com o decaimento da proporção $\mathrm{A} / \mathrm{A}_{0}$ nas medições de absorbância ao longo do tempo (Figura 22), indicando um aumento na taxa de aglomeração e sedimentação das nanopartículas nesse tempo e, consequentemente, uma diminuição na estabilidade dos sistemas ao longo do tempo considerado para as análises.

O comportamento das AgNP em meios aquosos com diferentes forças iônicas observado nos diferentes experimentos de estabilidade é semelhante aos dados obtidos 
por Bian e colaboradores (2011), e Yang e colaboradores (2013) para nanopartículas de óxidos de zinco e titânio, respectivamente. Analogamente a outras nanopartículas metálicas, as AgNP se agregam com maior facilidade em sistemas aquosos com alta concentração de sal, o que pode mudar as suas propriedades químicas, físicas e biológicas, resultando numa perda ou diminuição da toxicidade (LOK et al., 2007). Desta forma, a estabilidade das nanopartículas metálicas em solução aquosa depende, em grande medida, da força iônica (ZHANG et al., 2009; ZHOU; KELLER, 2010).

Apesar de que no preparo das suspensões de AgNP tenha sido utilizado um tempo de 40 minutos de sonicação, observou-se que o tamanho médio das nanopartículas foi maior do que o diâmetro médio calculado por microscopia eletrônica de transmissão (26 nm). Estes resultados sugerem que a agregação também pode ser causada pelo carácter hidrofóbico das AgNP que, além de induzir a aglomeração, pode aumentar a sua velocidade de sedimentação nos diferentes sistemas aquáticos (BIAN eta al., 2011; Yang et al., 2013).

Em ambientes aquáticos, a matéria orgânica natural, como por exemplo, o ácido húmico, pode se adsorver na superfície de nanopartículas, aprimorando a sua estabilidade nas suspensões (ZHANG et al., 2009). Em nosso trabalho, pode ser observado a partir da proporção $\mathrm{A} / \mathrm{A}_{0}$ que, na medida em que se aumenta a concentração de ácido húmico dissolvido nas diferentes amostras, as suspensões de AgNP se tornam mais estáveis (Figura 24), sendo a suspensão de nanopartículas mais estável na solução aquosa com concentração de $100 \mathrm{mg} / \mathrm{L}$ de AH. No entanto, em períodos mais prolongados (>120 minutos), as suspensões são instáveis, mesmo na mais alta concentração, o qual pode ser o resultado de presença de ponte entre as nanopartículas pela interação de múltiplos grupamentos funcionais da molécula do ácido húmico (BIAN et al., 2011). De fato nossos resultados demonstram o aumento da negatividade nos valores do potencial zeta das AgNP, especialmente quando na presença de concentrações de 50 e $100 \mathrm{mg} / \mathrm{L}$ de AH, e que podem ser atribuídas às moléculas de ácido húmico adsorvidas na superfície das nanopartículas de prata (ZHANG et al., 2009; BIAN et al., 2011). A adsorção do AH na superfície das AgNP foi corroborada nas imagens obtidas por microscopia eletrônica de transmissão (Figura 26). 
Como colocado anteriormente, a adsorção do AH na superfície das AgNP foi observada nos resultados obtidos pela microscopia eletrônica de transmissão (Figura 26 e 30) além de ser observado nos espectros ATR-FTIR (Figura 31), dado pelo deslocamento das posições dos picos correspondentes aos alongamentos assimétricos (a partir de $1562,8 \mathrm{~cm}^{-1}$ a $\left.1665,7 \mathrm{~cm}^{-1}\right)$ e simétricos $\left(1378,0 \mathrm{~cm}^{-1}\right.$ a $\left.1446,3 \mathrm{~cm}^{-1}\right)$ do grupo carboxila. A formação de novos picos e o deslocamento dos picos nos espectros FTIR, sendo mais evidente na amostra após 3 h, sugerem a formação de complexos de esfera interna, devido a uma interação do AH com as AgNP (BRONSTEIN et al., 2007). De fato, os picos em $\sim 1650 \mathrm{~cm}^{-1}, \sim 1582 \mathrm{~cm}^{-1}$ e a banda que aparece em $\sim 1445 \mathrm{~cm}^{-1}$ podem ser atribuídos, respectivamente, às vibrações assimétrica e simétrica de ligações C-O do complexo carboxila-prata, na superfície das nanopartículas.

A separação do número de onda entre as bandas de IR assimétricas e simétricas C00- $\left(137 \mathrm{~cm}^{-1}\right)$ indica que a interação entre a cabeça do carboxilato e o átomo metálico (neste caso prata) é uma coordenação do tipo ponte. Quando considerado o pico dividido em $\sim 1650 \mathrm{~cm}^{-1}$, esta diferença do número de onda é de $204 \mathrm{~cm}^{-1}$ e as interações mais propensas a serem formadas são do tipo monodentadas (NAKAMOTO, 2009). É importante considerar que as alterações espectrais dos ácidos carboxílicos devem ser interpretadas em termos de equilíbrio ácido-base entre fracções - $\mathrm{COOH}$ e -COO, assim, como uma função do pH do meio. Consequentemente, mais de um tipo de interação poderia coexistir entre o $\mathrm{AH}$ e as AgNP. Além disso, o AH apresenta uma variedade de componentes incluindo quinonas, fenóis, catecóis e porções de açúcar (RODRIGUES et al., 2009), que também podem se complexar com a superfície das AgNP.

A complexação entre o AH e as AgNP também foi confirmada por XPS (Figuras 36, 37 e 38), sendo possível observar os picos associados a ligações $\mathrm{C}-\mathrm{C}, \mathrm{C}-\mathrm{H}, \mathrm{C}-\mathrm{O}$ e $\mathrm{O}=\mathrm{C}-\mathrm{OH}$, característicos da molécula de $\mathrm{AH}$, na superficie das AgNP. Estas ligações estão relacionadas aos grupos funcionais que possuem alta capacidade de complexação com os íons metálicos, tais como os grupamentos carboxílicos e fenólicos (ZHANG et al., 2009; GAO et al., 2012). A dissociação dos grupamentos carboxila pode explicar os valores negativos do potencial zeta (BIAN et al., 2011), indicando também a possível adsorção/complexação do AH na superfície das AgNP. 
Dentre as diferentes técnicas de análise espectroscópicas, a análise por XPS tem uma contribuição importante para a caracterização da superfície dos materiais. A energia de ligação obtida pela técnica de XPS é resultante do ambiente químico existente na amostra, tornando o XPS uma ferramenta importante na análise de estados de oxidação dos elementos associados à superfície da amostra (MOULDER et al., 1995). Isto possibilitou a análise química elementar, quantitativa e estados de oxidação das AgNP em pH neutro, diferentes tempos experimentais $(0,24,48$ e 96 horas) e meios dispersantes (água MQ, água REC e água SIST, com e sem a presença de AH).

Termodinamicamente, os produtos de solubilidade e as constantes de estabilidade das AgNP ligadas com compostos orgânicos, tais como o $\mathrm{AH}$, podem ser úteis para prever as espécies de prata, a sua solubilidade e no geral o seu comportamento no ambiente (HASHIMOTO et al., 2015). As espécies predominantes de prata no ambiente são $\mathrm{AgCl}, \mathrm{Ag}_{2} \mathrm{~S}$ e $\mathrm{Ag} 0$, o que depende do potencial redox do sistema, podendo competir em diferentes ambientes com outros íons metálicos para estabelecer ligações com os sulfuretos (HASHIMOTO et al., 2015).

Nossos resultados mostraram que a única amostra que apresentou as mudanças no estado de oxidação foram as AgNP suspendidas em água REC+AH. Embora a maioria dos artigos descreva que as nanopartículas de prata podem ser oxidadas, principalmente para Ag (I) ou Ag (II) (BABAPOUR et al., 2011; AGNIHOTRI et al., 2013), no nosso estudo as amostras apresentaram os estados de oxidação, Ag (0) e Ag (III). Esses resultados corroboram os dados obtidos no parâmetro Auger (Figura 35), e com o componente relacionado às ligações Ag-O (Figuras 37E-H). Assim, a oxidação das AgNP poderia ter sido causada pelas concentrações de sais utilizadas no preparo da água REC e também, pela presença do AH (Figuras 39 e 40). O AH é conhecido pelas suas propriedades redox, cujo potencial de redução é de 0,5-0,7 V, devido aos seus grupamentos fenólicos e hidroquinonas implicadas nas reações (TIPPING, 2005). Além disso, as ligações podem influenciar o estado físico-químico da matéria húmica e assim, suas interações com outros componentes do sistema ambiental (TIPPING, 2005). Deste modo, é importante conhecer como as substâncias húmicas podem influenciar o comportamento dos cátions, e também, como os cátions influenciam mudanças nas substâncias húmicas, desempenhando um papel importante nas reações redox fotoquímicas em águas 
naturais. Vale ressaltar que a complexação entre as AgNP e o AH pode produzir novas espécies químicas, alterando as propriedades de transporte no meio, a biodisponibilidade e a toxicidade de AgNP em diferentes organismos (TIPPING, 2005; GAO et al., 2012; WIRTH et al., 2012; KIM et al., 2013; MOUSAVI et al., 2015). A biodisponibilidade dos metais está intimamente relacionada com a sua especiação química na solução que se encontram suspendidos.

Os valores de pH $(7,5 \pm 0,5)$ podem causar a desprotonação dos grupamentos carboxílicos e fenólicos do $\mathrm{AH}$, resultando numa maior carga negativa e caráter iônico, o qual foi observado nos resultados do potencial zeta (Figuras 25B, 28 e 29B) e também nos espectros de ATR-FTIR pela ausência da banda de absorção do "stretching" do C=0 em $1720 \mathrm{~cm}^{-1}$ (Figura 31). Sabe-se que a complexação entre o AH e as AgNP pode diminuir em pH ácidos (desde pH 6,0), e em pH 7,5-9,0 a capacidade de solubilidade e complexação do AH aumenta de maneira que, em valores de pH mais elevados os grupamentos carboxílicos e fenólicos são desprotonados (BIAN et al., 2011; MOUSAVI et al., 2015). Isso porque as moléculas de AH se tornam mais abertas (em forma linear), devido à diminuição das ligações intra e intermoleculares do hidrogênio e pelo aumento das forças de repulsão entre os grupamentos funcionais dissociados (BIAN et al., 2011).

Os resultados indicam alta probabilidade de que as AgNP que não se oxidaram ao longo de 96 horas, na água MQ e REC sem AH, permaneçam como prata metálica $\left(\mathrm{Ag}^{0}\right)$ (Figuras 32 e 34). Para estas amostras, as energias de ligação $\mathrm{Ag} 3 \mathrm{~d}_{3 / 2}(374,5 \mathrm{eV})$, Ag $3 d_{5 / 2}(368,4 \mathrm{eV})$ e a separação do dubleto $3 \mathrm{~d}$ da $\mathrm{Ag}(\sim 6 \mathrm{eV})$ indicam que as AgNP se encontravam no estado de oxidação $\mathrm{Ag}^{0}$. Estas energias de ligação para $\mathrm{Ag}^{0}$ também foram descritos por Murray e colaboradores no 2005, e por Agnihotri e colaboradores no 2013. Os resultados observados (AgNP não oxidadas ou pouco oxidadas - neste último caso fora do limite de resolução do equipamento de XPS) podem ser explicados pelo fato que, a concentração de cátions $\left(\mathrm{Ca}^{2+}, \mathrm{Mg}^{2+}, \mathrm{Na}^{+}, \mathrm{K}^{+}\right.$e $\left.\mathrm{Cl}^{-}\right)$provenientes dos sais presentes na água MQ e SIST não foi suficiente para promover a oxidação das nanopartículas. Desta maneira, os resultados indicam que a oxidação da superfície das AgNP resulta da interação entre o ácido húmico $(20 \mathrm{mg} / \mathrm{L})$ e os sais presentes no meio (294 mg/L CaCl $2 . \mathrm{H}_{2} \mathrm{O}, 123,3 \mathrm{mg} / \mathrm{L} \mathrm{MgSO}_{4} .7 \mathrm{H}_{2} \mathrm{O}, 63 \mathrm{mg} / \mathrm{L} \mathrm{NaHCO}_{3}$ e 5,5 mg/L KCl). 
Em resumo, as nanopartículas de prata $\left(\mathrm{Ag}^{0}\right)$ não são persistentes no meio ambiente aquático real, podendo se oxidar pela presença do oxigênio dissolvido e outros fatores como o pH, temperatura, composição química do meio dispersante e presença de ácido húmico (LIU E HURT, 2010). Além disso, a oxidação das AgNP em solução pode ocorrer em valores de pH baixo (SOTIRIOU et al., 2012), o que explica o porque em alguns dos resultados obtidos no presente experimento não tenham sido observadas mudanças no estado de oxidação (experimentos conduzidos em $\mathrm{pH}$ neutro). As mudanças observadas no estado de oxidação das amostras de AgNP na presença do AH (Figura 33), podem ser devidas também à presença de outros íons no meio tais como sódio, cálcio, potássio e magnésio (Figuras 39 e 40).

A dissolução das AgNP para formar íons de prata é uma das principais questões na avaliação de risco ambiental. Para avaliar a solubilidade das nanopartículas de prata, sob condições aeróbicas, deve ser considerada não só a presença de prata metálica, que é insolúvel em águas anaeróbicas, mas também a possível presença de uma camada de óxido $\left(\mathrm{Ag}_{2} \mathrm{O}\right)$ na superfície da nanopartícula (XIU et al., 2011). Em contraste com a prata metálica, o óxido de prata se dissolve em água pura (Kps=4x10-11) (JOHNSTON et al., 1933), que resulta na liberação de cátions $\mathrm{Ag}^{+}\left(2 \mathrm{Ag}_{(\mathrm{s})}+1 / 2 \mathrm{O}_{2(\mathrm{aq})}+2 \mathrm{H}^{+} \rightarrow 2 \mathrm{Ag}^{+}{ }_{(\mathrm{aq})}+\mathrm{H}_{2} \mathrm{O}_{(\mathrm{aq})}\right)$. Uma vez que a camada de $\mathrm{Ag}_{2} \mathrm{O}$ é dissolvida, a oxidação/dissolução das AgNP ocorre apenas na presença de um oxidante em solução (LEVARD et al., 2012).

Os resultados de liberação de íons no nosso estudo mostraram que a quantidade de íons liberados aumentava com o aumento da concentração de AgNP (Figura 41), exceto para a suspensão de AgNP em água $M Q+A H$, onde não se observou este padrão de liberação de íons (Figura 41A). Além disso, os íons liberados a partir das AgNP suspendidas em água MQ, SIST e REC foram maiores nas amostras que não continham $\mathrm{AH}$ e, especificamente, as AgNP suspendidas em água $\mathrm{REC}+\mathrm{AH}$ liberaram uma maior quantidade de íons (Figura 41C), os quais provavelmente foram produzidos pela oxidação da superfície das nanopartículas (Figuras 33E-H, 39, 40), quando comparado com as amostras de AgNP suspendidas em água MQ+AH (Figuras 32, 41A) e água SIST+AH (Figuras 34 e 41B). A formação de complexos entre o AH e as AgNP pode induzir modificações na superfície das nanopartículas, atrasando e/ou diminuindo ligeiramente este processo de oxidação. Lee e colaboradores (2012), e Mousavi e 
colaboradores (2015) observam também que, em um ambiente mais complexo, a taxa de conversão de íons de prata poderia ser maior a partir de AgNP sem cobertura do que para AgNP com cobertura. Consequentemente, a formação de complexos de prata depende fortemente das condições ambientais e, por conseguinte, torna-se indispensável a caracterização do ambiente químico em que as nanopartículas estão suspendidas.

Baseados nos resultados obtidos e ilustrados na Figura 42, pode-se inferir que entre as 24 e 48 horas, na amostra AgNP REC, os íons liberados a partir das AgNP $(20 \mathrm{mg} / \mathrm{L})$ possivelmente atingiram um platô, sendo semelhantes aos dados obtidos por Sotiriou e colaboradores (2012). Tais pesquisadores verificaram uma pequena liberação de íons imediatamente após a sua dispersão, que foi atribuída à presença de uma pequena fração/camada de óxidos de prata na superfície das AgNP, as quais podem ser parcialmente oxidadas em condições ambientais. Adicionalmente, as partículas de prata de menor tamanho podem ter sido oxidadas mais rapidamente do que as maiores (SOTIRIOU E PRATSINIS, 2010), e o óxido de prata tem maior solubilidade do que a prata metálica quando em contato com a água, facilitando assim a liberação de íons. Nesta mesma amostra, às 96 horas, a quantidade de íons liberada foi menor do que no tempo inicial. Este comportamento pode ser explicado pela ocorrência de um processo chamado "Ostwald ripening". Este mecanismo explica como os pequenos aglomerados, partículas ou átomos/moléculas transferem sua massa para aglomerados maiores (ZENG, 2007), reduzindo a área superficial das nanopartículas e, ao mesmo tempo, formando precipitados. Além disso, a diminuição da concentração de íons de prata possivelmente foi originada a partir da interação catiônica com ânions presentes no meio, tais como o sulfato e o cloreto, resultando na sedimentação, o que corrobora com os dados obtidos por Kim e colaboradores (2013).

No estudo realizado por Henglein (1998) e Zeng (2007), afirma-se que os íons de prata podem adsorver-se quimicamente (quimissorção) às nanopartículas, onde cada íon adsorvido torna-se parte da partícula. Outra teoria que poderia explicar este comportamento é a hipótese proposta por Sotiriou e colaboradores (2012), os quais afirmam que a liberação de íons de nanopartículas sonicadas atinge um platô, imediatamente após sonicação. Isto provavelmente acontece por que a camada de óxido 
que está próxima ao "core" da nanopartícula passa a ser Ag (0), aumentando o conteúdo de prata metálico.

Em contraste, os íons de prata liberados nas amostras de AgNP (20 mg/L) na presença de $20 \mathrm{mg} / \mathrm{L}$ de AH (AgNP AH REC e AgNP AH MQ) (Figura 42), tanto na água reconstituída como na água deionizada, exibiram um aumento na sua concentração, comparado com a concentração dos íons de prata na água sem AH. O aumento da concentração de prata dissolvida (íons) foi provavelmente induzido pela complexação dos grupamentos carboxílicos e tióis orgânicos do AH com os íons de prata (KIM et al., 2013). A concentração de íons de prata dissolvidos aumentou ao longo do tempo nessas amostras (AgNP AH REC e AgNP AH mQ), provavelmente devido à estabilidade coloidal das nanopartículas em meios com AH (Figuras 24, 25, 27, 28 e 29). Isso está de acordo com a hipótese sugerida por Manoharan e colaboradores (2014), na qual se descreve que quando o $\mathrm{AH}$ é adicionado a uma dispersão de AgNP, liga-se às nanopartículas e íons; uma vez complexados continuam liberando íons, resultando numa diminuição no tamanho das AgNP. A taxa de dissolução das AgNP ligadas a uma determinada quantidade de moléculas de $\mathrm{AH}$ é altamente influenciada pelo $\mathrm{AH}$, sendo que os íons que se ligam ao AH podem formar novas AgNP. Estes novos de AgNP, ligados ao AH, também podem liberar íons de modo semelhante ao descrito anteriormente e, esses íons podem voltar a formar novas AgNP. Este processo pode ser repetido continuamente.

Embora os resultados de XPS tenham mostrado que o estado predominante de prata é $\mathrm{Ag}(0)$ para as amostras de AgNP suspendidas em água MQ e SIST, observaram-se íons liberados (Figuras 41A e 41B) em todas as concentrações avaliadas. Isto pode ser explicado pelo fato de que a camada de óxido de prata formada foi mais fina do que o limite de detecção do espectrómetro XPS (como mencionado em parágrafos anteriores), e outra possibilidade é que o óxido de prata formado tenha sido dissolvido rapidamente em forma de íons para o meio, desde que os íons de prata são provenientes, principalmente, da oxidação de partículas metálicas (LIU E HURT, 2010; SOTIRIOU et al., 2012). Neste sentido, e concordando com o afirmado por Sotiriou e colaboradores (2012), os íons de prata são liberados a partir da superfície das AgNP e a cinética de liberação é determinada pela área superficial das nanopartículas, $\mathrm{pH}$, temperatura, presença de outros íons, processos de sonicação, entre outros fatores. 
Sabe-se que as nanopartículas de menor tamanho têm uma maior superfície de contato e, consequentemente, a liberação de íons pode ser maior, constituindo a principal causa de toxicidade das AgNP (LIU et al., 2010; YU et al., 2013). No entanto, no estudo desenvolvido por Agnihotri e colaboradores (2013) verificou-se que a quantidade de íons liberados foi maior nas amostras em que as nanopartículas apresentaram maior agregação. Isto poderia explicar os resultados do nosso estudo, onde as amostras de AgNP com diâmetro hidrodinâmico maior (Figura 27), mostraram uma maior liberação de íons do que aquelas com menor diâmetro hidrodinâmico.

Apesar da utilização das AgNP ter aumentado significativamente nos últimos anos, com uma produção mundial total estimada em 500 toneladas por ano (FABREGA et al., 2011), os dados empíricos disponíveis sobre os níveis ambientais de AgNP são poucos e, dada a sua produção muito significativa, é muito provável que as AgNP entrem em contato com o meio ambiente aquático (AERLE et al., 2013). De acordo com os estudos, a toxicidade deste metal é afetada pela sua especiação no meio, que por sua vez, é afetada por uma série de parâmetros, incluindo composição iônica e matéria orgânica dissolvida na água. Como consequência da diminuição da biodisponibilidade da prata quando a força iônica aumenta na água, os peixes que habitam ambientes de água doce são mais suscetíveis à toxicidade das espécies de prata quando comparados com os peixes marinhos (WOOD et al., 1999).

Os experimentos desenvolvidos no presente estudo foram realizados utilizando água do sistema de manutenção dos peixes (água doce), de acordo com os parâmetros estabelecidos pela OECD 236 e 203, para avaliar a toxicidade aguda embrio-larval e em peixes adultos de Danio rerio, respectivamente. A mortalidade observada nos organismos expostos (embriões e peixes adultos) apenas às AgNP pode estar associada à aderência/adsorção de aglomerados de AgNP no córion dos embriões, larvas e brânquias dos peixes adultos, os quais podem permanecer na superfície causando estresse por contato físico, falência na troca de oxigênio e/ou produção excessiva de espécies reativas de oxigênio (ERO), resultando em estresse oxidativo (CHENG et al., 2007; ZHU et al., 2009). É importante destacar que, tanto nos experimentos de toxicidade aguda embrio-larval como de toxicidade em peixes adultos de Danio rerio foi observado que a presença de ácido húmico no sistema aquoso avaliado modificou, 
principalmente, a toxicidade decorrente da exposição às AgNP. Esta diminuição da toxicidade dada pela presença do $\mathrm{AH}$ pode ser observada no aumento dos valores calculados para a CL50 nos testes realizados em embriões e em peixes adultos de zebrafish (Figuras 43 e 49).

Os resultados mencionados estão de acordo com a informação encontrada na literatura, onde se descreve que o $\mathrm{AH}$ pode ser adsorvido na superfície das nanopartículas, reduzindo a sua aglomeração (HYUNG et al., 2007), modificando a sua biodisponibilidade e toxicidade em organismos aquáticos (BALAREZO et al., 2002; VOETS et al., 2004), bactérias (WIRTH et al., 2012; ZHANG et al., 2012) e nematoides (YANG et al., 2014). Estes trabalhos e os resultados obtidos por Gunsolus e colaboradores (2015) sugerem que a adsorção da matéria orgânica natural-MON na superfície das AgNP (pode diminuir o total de íons liberados, bem como modular a adsorção ou interiorização das nanopartículas pelos organismos) é o principal mecanismo de mitigação de toxicidade.

Os outros resultados obtidos nos experimentos de toxicidade embrio-larval indicam que os efeitos adversos (edema cardíaco, total de mortos, atraso na eclosão e alterações no equilíbrio) foram observados em menor proporção para as larvas expostas a AgNP+AH do que para grupos expostos a AgNP, sugerindo que tanto a quantidade de AgNP quanto de íons liberados a partir das concentrações testadas, estão correlacionados com os efeitos adversos mencionados anteriormente. Além do mais, a quantidade de prata incorporada, durante 96 horas, foi menor em larvas expostas a AgNP+AH do que para aqueles expostos apenas a AgNP. Estes resultados sugerem que, embora houvesse liberação de íons nas amostras de $\mathrm{AgNP}+\mathrm{AH}$, estes poderiam ter formado complexos com moléculas de $\mathrm{AH}$, reduzindo os efeitos tóxicos em embriões de Danio rerio (Figuras 43 e 44).

Embora não tenham sido realizados estudos sobre os mecanismos de toxicidade das AgNP com e sem a presença de $\mathrm{AH}$, nossos resultados sugerem que a toxicidade observada nos embriões do zebrafish poderia estar relacionada com a quantidade de íons liberados (Figura 41B) ou/e pelo estresse causado pelo contato/interação direto entre os aglomerados das AgNP com os embriões/larvas (Figura 47). Além da mortalidade, outros efeitos tóxicos (com significância estatística) foram observados 
durante o desenvolvimento embrio-larval, tais como, atraso na eclosão, bradicardia, atraso na absorção do saco vitelínico, alterações no equilíbrio, edema generalizado e cardíaco, bem como, presença de embriões malformados. Estes efeitos tóxicos das AgNP podem ter sido causados principalmente pela produção de íons de prata (LUOMA et al., 1995b; SOTIRIOU E PRATSINIS, 2010; LÓPEZ-SERRANO et al., 2014), mas pode também ser causado na mesma extensão pelas nanopartículas.

Outros mecanismos ou modos de toxicidade das AgNP são o contato direto com os aglomerados/precipitados de nanopartículas, nanopartículas liberadas como colóides na solução e por íons liberados a partir tanto dos aglomerados como das nanopartículas (AGNIHOTRI et al., 2013). Portanto, a toxicidade das AgNP não pode estar relacionada apenas com as concentrações de prata testadas, mas também com as espécies de prata presentes no meio.

A incorporação de prata nas larvas (Figura 48) pode ter acontecido pela endocitose de AgNP e/ou pelo transporte de íons ao interior das células. Os estudos realizados por Lee e colaboradores (2007), e Asharani e colaboradores (2008) reportaram que as AgNP podem ser incorporadas por embriões de zebrafish através dos canais dos poros do córion, e posteriormente se localizar no cérebro, coração, saco vitelínico e sangue, durante o desenvolvimento embrionário. Uma vez incorporados, os íons de prata podem se ligar aos grupamentos tiol das enzimas, tais como a NADH desidrogenase (ASHARANI et al., 2009; LIU E HURT, 2010), causando os efeitos tóxicos apresentados na Figura 44. Outras formas de toxicidade causadas pela exposição às AgNP pode acontecer após a endocitose ou adesão das AgNP na membrana celular, uma vez que existe a possibilidade de gerar um fluxo de íons através da membrana e/ou de transportar ativamente os íons $\mathrm{Ag}^{+}$para alvos biológicos sensíveis no interior das células (LIU et al., 2010). Adicionalmente, também é conhecido que as AgNP podem causar outros efeitos tóxicos como incrementar a produção de ERO, interromper a cadeia de transporte de elétrons, induzir danos estruturais e baixa produção de ATP (ASHARANI et al., 2009).

Nos experimentos realizados com peixes adultos, foi observado que durante as primeiras oito horas de exposição, os peixes que sobreviveram (dos subgrupos 10, 20 e $30 \mathrm{mg} / \mathrm{L}$ de AgNP) permaneceram no fundo do aquário, mas depois de 24 horas de exposição, não houve diferenças visíveis no comportamento entre o controle e os 
subgrupos expostos. Outras alterações observadas foram a perda do equilíbrio, natação errática e circular, salto e produção de muco branquial (Tabelas 10 e 11), as quais foram observadas, principalmente, a partir da concentração de $20 \mathrm{mg} / \mathrm{L}$ de AgNP, enquanto que para os grupos expostos às AgNP+AH foram observadas nos peixes expostos a 60 $\mathrm{mg} / \mathrm{L}$ de AgNP+AH. Durante 96 horas de exposiçao às AgNP e às AgNP+AH, houve ocorrência de mortalidade nos diferentes subgrupos experimentais a partir da concentraçao de $10 \mathrm{mg} / \mathrm{L}$ AgNP (Tabelas 10 e 11). Desta forma, a curva concentraçãoresposta ou a CL50-96h foi calculada em 25,0 mg/L para os peixes expostos a AgNP, e 40,56mg/L para os expostos a AgNP+AH. Estes resultados indicam que o AH, além de diminuir a mortalidade, contribui na diminuição da ocorrência dos sinais clínicos. As alterações clínicas descritas anteriormente sugerem a ocorrência de toxicidade respiratória, também observada nos estudos realizados por Bilberg e colaboradores (2012), e por Krishnaraj e colaboradores (2016).

Estudos prévios determinaram que a $\mathrm{CL}_{50-48 \mathrm{~h}}$ foi de 7,07 $\mathrm{mg} / \mathrm{L}$ para zebrafish expostos a óxidos metálicos revestidos por AgNP com um diâmetro médio de 44,5 e 216 nm (GRIFFITT et al., 2007). Choi e colaboradores (2010) realizaram um estudo com zebrafish encontrando a CL50-24h em $250 \mathrm{mg} / \mathrm{L}$ para AgNP de 5-20 nm de diâmetro, sendo maior do que o valor da CL50 encontrada por Griffitt e colaboradores (2007) e no presente estudo. Em outro estudo realizado com peixes da espécie Oryzias latipes, a CL5096h foi determinada em 34,6 $\mu \mathrm{g} / \mathrm{L}$ para AgNP não revestidas de $50 \mathrm{~nm}$ de diâmetro (CHAE et al., 2009), cujo valor calculado da CL50-96h é diferente ao encontrado no presente estudo para AgNP de 26 nm de diâmetro. Krishnaraj e colaboradores (2016) determinaram que a $C_{50-96 h}$ foi de $142,2 \mu \mathrm{g} / \mathrm{L}$ em peixes adultos de Danio rerio. Por conseguinte, é evidente que as nanopartículas de prata de diferentes tamanhos, com ou sem agentes estabilizantes, podem causar diferentes graus de toxicidade em organismos, tempos e condições de exposição diferentes.

Um biomarcador é definido como alterações qualitativas e quantitativas decorrentes da exposição a uma substância determinada, obtidos por meio de medidas de fluidos corporais, células, tecidos e/ou do organismo, que indicam, em termos bioquímicos, celulares, fisiológicos, comportamentais ou energéticos, a presença de substâncias contaminantes, a magnitude da resposta do organismo alvo (LAM E GRAY, 
2003) ou do grau de contaminação (WALKER et al., 1996). Neste contexto, a fragmentação do DNA e as alterações histológicas são considerados biomarcadores de efeito (CÁCERES-VÉLEZ et al., 2015).

No presente estudo foram utilizadas a fragmentaçao do DNA e as alteraçoes histológicas como biomarcadores da exposição a AgNP e AgNP+AH. Os resultados obtidos pelo teste do cometa (Figura 50) e micronúcleo (Tabela 12) mostraram que as concentraçoes testadas de AgNP e AgNP+AH não causaram fragmentacão no DNA dos eritrócitos dos peixes expostos, mas foram observadas alterações nucleares estatísticamente significativas relacionadas à frequência de células binucleadas $(p \leq 0,01)$ e células com núcleo "blebbed" ( $\mathrm{p} \leq 0,05)$.

A formação de anormalidades nucleares (como células com núcleo "blebbed"), cadeias de cromatina, células binucleadas e micronúcleos estão intimamente relacionadas com o tipo de quebra-fusão-ponte de alterações mitóticas causadas principalmente durante a anáfase. As anormalidades no formato nuclear podem ser essencialmente consideradas como indicadoras de instabilidade genética e heterogeneidade, independente da complexidade citogenética dos organismos (GISSELSSON et al., 2001). Algumas pesquisas afirmam que as irregularidades nucleares indicam a associação entre a exposicão a substâncias químicas e a formação de aberrações cromossômicas estruturais (AMBROS et al., 1997). Adicionalmente, as anormalidades nucleares, incluindo variabilidade no tamanho nuclear, estrutura da cromatina anormal e as irregularidades no formato nuclear, têm sido frequentemente observadas em tecidos malignos (BIBBO, 1997; GISSELSSON et al., 2001), mas os mecanismos por trás desses fenômenos ainda são pouco conhecidos.

0 teste do cometa tem sido amplamente utilizado como um teste de genotoxicidade que pode detectar danos primários/reversíveis no DNA, tais como sítios álcali-lábeis e quebras de fita simples e dupla no DNA de células individuais, (SINGH et al., 1988; GIANNOTTI et al., 2002; KIMURA et al., 2013), enquanto que o teste de MN é um teste bem estabelecido para detectar quebras de fita dupla do DNA irreparáveis, efeitos clastogênicos, aneugênicos (BOLOGNESI et al., 2004; KIMURA et al., 2013), danos cromossômicos fixos do tipo estrutural e/ou numérico (GOETHEM et al., 1997; KRISHNA E HAYASHI, 2000). A combinação desses testes resulta em uma abordagem sensível para 
a detecção eficiente do efeito de múltiplas classes de compostos genotóxicos em diferentes órgãos-alvo (VASQUEZ, 2010). 0 anteriormente exposto permite inferir que tanto as $\mathrm{AgNP}$, como as $\mathrm{AgNP}+\mathrm{AH}$, não possuem potencial genotóxico ou mutagênico significativo em Danio rerio, associado com as condições utilizadas no desenvolvimento dos experimentos, tais como tempo e tipo de exposição, concentrações avaliadas e o organismo teste selecionado, entre outras condições mencionadas nos materiais e métodos.

Além dos biomacadores de genotoxidade, foi utilizado o biomarcador histopatológico a fim de conhecer as alterações nas brânquias, fígado e intestino dos peixes, associadas à exposição de AgNP ou de AgNP+AH. Esses resultados indicaram que as AgNP na presença de $\mathrm{AH}$ podem induzir alterações adicionais, sendo significativas a partir da concentração de $30 \mathrm{mg} / \mathrm{L}$ de AgNP+AH (Figura 51). Isto provavelmente é devido a que o AH contribui com a estabilidade das nanopartículas na água (Figuras 24 e 27), permanecendo mais tempo em suspensão e consequentemente interagindo com os peixes. Em parágrafos anteriores tinha se mencionado que a liberação de íons a partir das AgNP+AH (Figura 42) foi dependente do tempo, enquanto que para as AgNP não foi observado este comportamento. Podemos inferir que a crescente liberação de íons nas amostras de $\mathrm{AgNP}+\mathrm{AH}$ pode estar relacionada com as alterações descritas especificamente para este grupo, embora a avaliação histopatológica tenha sido realizada no tempo final da exposição.

Uma das principais vias de absorção e toxicidade das AgNP é através das brânquias, causando efeitos adversos na osmorregulação, semelhantes aos descritos para a prata iônica (GRIFFITT et al., 2009; FARMEN et al., 2012). Para as AgNP, os efeitos sobre a atividade da $\mathrm{Na}^{+} / \mathrm{K}^{+}$-ATPase nas brânquias tem sido atribuída à dissolução de íons de prata a partir das partículas, e/ou à presença de íons de prata na superfície das nanopartículas (GRIFFITT et al., 2009; OSBORNE et al., 2015). Os mecanismos pelos quais estes efeitos específicos ocorrem pela exposição às AgNP não são claros ainda, mas podem ser devido a danos da superfície das brânquias causados pela presença de partículas em suspensão e/ou dissociação de íons de prata a partir de AgNP adsorvidas no muco presente ao redor das membranas branquiais (AERLE et al., 2013). 
Autores como Osborne e colaboradores (2015) afirmam que as alterações morfológicas observáveis nas brânquias de peixes expostos a nanopartículas de prata são em grande medida decorrentes dos íons presentes no meio. Os autores anteriormente mencionados encontraram nas brânquias alterações como fusão lamelar, hiperplasia e inflamação; e no intestino observaram processos inflamatórios, vacualizacão, perda de microvilosidades, aumento do numero de células caliciformes e danos na lâmina própria. Outros efeitos observados em zebrafish pela exposição às AgNP são apoptose nas células do fígado-após 24 horas de exposição (CHOI et al., 2010); danos na membrana celular, núcleos picnóticos e ruptura completa das células, decorrentes do estresse oxidativo em brânquias e fígado, após 96 horas de exposição (KRISHNARAJ et al., 2016).

Os resultados sobre a quantidade de prata presente nos diferentes órgãos avaliados nos peixes adultos de zebrafish sugerem que, embora nas análises de acumulação/ biodistribuição de prata nos órgãos analisados (dos peixes expostos tanto às $\mathrm{AgNP}$ como às $\mathrm{AgNP}+\mathrm{AH}$ ) não tenha sido encontrada significância estatística para todas as concentrações avaliadas em relação ao grupo controle, para 96 horas de exposição, pode ter significado biológico a longo prazo.

Independentemente se os peixes foram expostos a $\mathrm{AgNP}$ ou $\mathrm{AgNP}+\mathrm{AH}$, o órgão que contém maior quantidade de prata é o intestino, e o músculo o que contém menor quantidade de prata. É importante mencionar que a diferença entre a quantidade de prata presente nos peixes destes dois grupos ( $\mathrm{AgNP}$ ou $\mathrm{AgNP}+\mathrm{AH})$ está relacionada com a presença de ácido húmico, onde foi observada redução da incorporação de prata nas diferentes soluções aquosas avaliadas. Desta maneira, o acúmulo de prata em diferentes órgãos de peixes provenientes de água naturais se dá de forma dependente da presença de ácido húmico, concentração de prata, do tempo de exposição, e da afinidade da prata para determinados órgãos (GIGUÈRE et al., 2004).

O acúmulo de metais em peixes inclui diferentes vias, como a ingestão de alimentos contaminados, material particulado em suspensão, troca de íons (liberados do metal) através de brânquias e pele. A partir dessas vias, os metais podem ser absorvidos, entrando em contato com o sangue e posteriormente transportado para vários órgãos para armazenamento ou excreção (AKAN et al., 2012). Por enquanto, os estudos 
realizados em 1996 por Hogstrand e colaboradores, e Yamazaki e colaboradores mostraram que a prata é acumulada principalmente no fígado, seguido pela vesícula biliar, rim e brânquias de peixes de água doce. Deste modo, a dinâmica da concentração de metais em vários órgãos durante a exposição e depuração pode ser diferente. Por exemplo, no início de exposições a determinadas concentrações de metais, o acúmulo pode aumentar rapidamente nas brânquias e no intestino, enquanto que o acúmulo no músculo é muito menor e mais lento. Posteriormente à exposição (período de recuperação), os metais podem ser transportados rapidamente das brânquias e biodistribuídos pela corrente sanguínea para o resto do corpo, acumulando-se em outros órgãos, como o fígado, os rins e o músculo (JEZIERSKA, 2006).

Sabe-se que as brânquias são mais susceptíveis aos efeitos adversos aos xenobióticos, por serem altamente permeáveis, seguido da pele, que apresenta uma extensa área de exposição. Devido à estrutura e localização, tais órgãos apresentam maior vulnerabilidade aos efeitos adversos, por estarem em contato constante e direto com o ambiente (SEITBAYEV et al., 2013). Isto é um fator que pode determinar o acúmulo de metais (SANCHEZ et al., 1998), embora no nosso estudo a brânquia não tenha sido o órgão que continha maior quantidade de prata, foi o que presentou alterações histológicas. Isto indica que provavelmente as alterações nas concentrações avaliadas causam mudanças na sua estrutura, dadas principalmente pela interação física entre as AgNP e este órgão, além da quantidade de prata incorporada. Embora o intestino tenha sido o órgão que mais continha prata, este não apresentou mudanças histológicas provavelmente devido ao tempo de exposição.

O acúmulo de metais nos órgãos de peixe é uma função das taxas de absorção e eliminação, e as concentrações de metal em vários órgãos podem mudar durante e após a exposição, de acordo com vários padrões. Alguns fatores que influem na deposição de metais nos diferentes órgãos são a temperatura, dureza da água (principalmente concentração de cálcio), tempo de exposição, entre outros (AKAN et al., 2012). A temperatura da água pode estabelecer diferenças na deposição de metais em vários órgãos, sendo que as temperaturas mais elevadas promovem uma maior acumulação especialmente no rim e no fígado, possivelmente pela maior taxa metabólica, incluindo uma maior taxa de absorção e de ligação de metais (YANG E CHEN, 1996). A dureza da 
água afeta consideravelmente a absorção de metais em todo o epitélio branquial; o enriquecimento de água com cálcio reduz o acúmulo de metais nas brânquias (BALDISSEROTTO et al., 2005). O efeito do tempo é um problema complexo na distribuição do metal dentro do organismo devido afinidades diferentes dos vários metais para os tecidos de várias espécies de peixes (JEZIERSKA, 2006). Várias espécies de peixes provenientes do mesmo corpo de água podem acumular quantidades diferentes de metais, possivelmente pelos hábitos de vida e alimentação (AKAN et al., 2012), além da apresentação de metabolismos diferentes.

Os resultados obtidos nos estudos in vivo permitem inferir que as propriedades da superfície das AgNP, a interação entre as AgNP e o $\mathrm{AH}$ e as características físicoquímicas do meio determinam o comportamento das nanopartículas em ambientes aquáticos e, consequentemente, seus efeitos tóxicos. Assim, algumas das características físico-químicas a serem consideradas (baseados nos nossos achados) nos estudos nanoecotoxicológicos são a estabilidade, estado de agregação, modificação da superfície, dissolução das nanoparticulas, bem como a força iônica, matéria orgânica presente na água e pH do meio. 


\section{7.}

\section{$\mathbf{C}_{\text {onclusoōes }}$}

Os resultados obtidos no presente trabalho indicam que:

O ácido húmico tem a capacidade de mitigar não só os efeitos tóxicos, principalmente a mortalidade $(\sim 50 \%)$, mas também outros efeitos deletérios decorrentes da exposição às nanopartículas de prata, tanto em embriões, como em organismos adultos de Danio rerio. A diminuição dos efeitos tóxicos observados pode ser atribuída à adsorção do ácido húmico na superfície das AgNP, que por sua vez, induz mudanças na estabilidade e no potencial- $\zeta$ das nanopartículas de prata. Desta maneira, o ácido húmico, em ambientes aquáticos, aparece como um atenuador/remediador natural da água poluída com nanopartículas de prata. 


\section{8.}

\section{ReferênCias bibliográficas}

ABLAIN, J.; ZON, L. I. Of fish and men: using zebrafish to fight human diseases. Trends in Cell Biology, v. 23, n. 12, p. 584-586, 2013.

ADAMS, W. H. A.; KRAMER, J. R. Environmental Chemistry PORE WATERS. Environmental Chemistry, v. 18, n. 12, p. 2667-2673, 1999.

ADELEYE, A. S. et al. Persistence of commercial nanoscaled zero-valent iron (nZVI) and by-products. Journal of Nanoparticle Research, v. 15, n. 1, 2013.

AERLE, R. VAN et al. Molecular mechanisms of toxicity of silver nanoparticles in Zebra fish embryos. Environmental Science \& Technology, v. 47, p. 8005-8014, 2013.

AGNIHOTRI, S.; MUKHERJI, S.; MUKHERJI, S. Immobilized silver nanoparticles enhance contact killing and show highest efficacy: elucidation of the mechanism of bactericidal action of silver. Nanoscale, v. 5, n. 16, p. 7328-40, 2013.

AKAIGHE, N. et al. Humic acid-induced silver nanoparticle formation under environmentally relevant conditions. Environmental Science and Technology, v. 45, n. 9, p. 3895-3901, 2011.

AKAN, J. C. et al. Bioaccumulation of some heavy metals in fish samples from river benue in Vinikilang, Adamawa State, Nigeria. American Journal of Analytical Chemistry, v. 03, n. 11, p. 727-736, 2012.

ALI, S. et al. Zebrafish embryos and larvae: a new generation of disease models and drug screens. Birth defects research. Part C, Embryo today : reviews, v. 93, n. 2, p. 115-33, 2011.

ALLEN, H. J. et al. Effects from filtration, capping agents, and presence/absence of food on the toxicity of silver nanoparticles to Daphnia magna. Environmental Toxicology and Chemistry, v. 29, n. 12, p. 2742-2750, 2010.

AMBROS, I. M. et al. Neuroblastoma cells can actively eliminate supernumerary MYCN gene copies by micronucleus formation - Sign of tumour cell revertance? European Journal of Cancer, v. 33, n. 12, p. 2043-2049, 1997. 
ANGEL, V. et al. pH Effect on surfactant properties and supramolecular structure of humic substances obtained from sewage sludge composting 1 Centro de Investigación y Desarrollo en Electroquímica (CIDETEQ), Parque Tecnológico Querétaro, Sanfan- 2 Unidad Profesional In. Rev. Int. Contam. Ambie., v. 29, n. 3, p. 191-199, 2013.

ARUOJA, V. et al. Toxicity of nanoparticles of $\mathrm{CuO}, \mathrm{ZnO}$ and $\mathrm{TiO} 2$ to microalgae Pseudokirchneriella subcapitata. The Science of the total environment, v. 407, n. 4, p. 1461-8, 2009.

ASHARANI, P. V et al. Toxicity of silver nanoparticles in zebrafish models. Nanotechnology, v. 19, n. 25, p. 255102, 2008.

ASHARANI, P. V et al. Cytotoxicity and Genotoxicity of Silver. ACS Nano, v. 3, n. 2, p. 279$290,2009$.

ASHOKA, S. et al. Comparison of digestion methods for ICP-MS determination of trace elements in fish tissues. Analytica chimica acta, v. 653, n. 2, p. 191-9, 2009.

BABAPOUR, A. et al. Low-temperature sol-gel-derived nanosilver-embedded silane coating as biofilm inhibitor. Nanotechnology, v. 22, p. 155602, 2011.

BACCHETTA, C. et al. Toxicological effects induced by silver nanoparticles in zebra fish (Danio rerio) and in the bacteria communities living at their surface. Bulletin of Environmental Contamination and Toxicology, p. 1-7, 2016.

BAI, W. et al. Toxicity of zinc oxide nanoparticles to zebrafish embryo: a physicochemical study of toxicity mechanism. Journal of Nanoparticle Research, v. 12, n. 5, p. 16451654, 2010.

BALAREZO, A. L. et al. Influence of Humic Acid on 1-Aminopyrene Ecotoxicity During Solar Photolysis Process. International Journal of Molecular Sciences, v. 3, n. 11, p. 1133-1144, 2002.

BALDISSEROTTO, B.; CHOWDHURY, M. J.; WOOD, C. M. Effects of dietary calcium and cadmium on cadmium accumulation, calcium and cadmium uptake from the water, and their interactions in juvenile rainbow trout. Aquatic toxicology, v. 72, n. 1-2, p. 99-117, 2005.

BALOGH, L. et al. Dendrimer - Silver complexes and nanocomposites as antimicrobial agents. Nano letters, v. 1, n. 1, p. 18-21, 2001.

BARRERA, C.; HERRERA, A. P.; RINALDI, C. Colloidal dispersions of monodisperse magnetite nanoparticles modified with poly(ethylene glycol). Journal of Colloid and Interface Science, v. 329, n. 1, p. 107-113, 2009.

BARSIENE, J. et al. Investigation of micronuclei and other nuclear abnormalities in peripheral blood and kidney of marine fish treated with crude oil. Aquatic toxicology, v. 78 Suppl 1, p. S99-104, 2006. 
BENN, T. M.; WESTERHOFF, P. Nanoparticle Silver Released into Water from Commercially Available Sock Fabrics. Environmental Science \& Technology, v. 42, p. 4133-4139, 2008.

BENNETT, S. W. et al. Stability, metal leaching, photoactivity and toxicity in freshwater systems of commercial single wall carbon nanotubes. Water Research, v. 47, n. 12, p. 4074-4085, 2013.

BERNIER, M. C. et al. Titanium dioxide nanoparticles disturb the fibronectin-mediated adhesion and spreading of pre-osteoblastic cells. Langmuir, v. 28, n. 38, p. 1366013667, 2012.

BERNOT, R. J.; BRANDENBURG, M. Freshwater snail vital rates affected by non-lethal concentrations of silver nanoparticles. Hydrobiologia, v. 714, n. 1, p. 25-34, 2013.

BHATTACHARJEE, S. et al. Role of surface charge and oxidative stress in cytotoxicity of organic monolayer-coated silicon nanoparticles towards macrophage NR8383 cells. Particle and fibre toxicology, v. 7, n. 1, p. 25, 2010.

BIAN, S.-W. et al. Aggregation and dissolution of $4 \mathrm{~nm} \mathrm{ZnO}$ nanoparticles in aqueous environments: influence of $\mathrm{pH}$, ionic strength, size, and adsorption of humic acid. Langmuir: the ACS journal of surfaces and colloids, v. 27, n. 10, p. 6059-68, 2011.

BIANCHINI, A. et al. Acute silver toxicity in aquatic animals is a function of sodium uptake rate. Environmental Science and Technology, v. 36, n. 8, p. 1763-1766, 2002.

BIBBO, M. Comprehensive Cytopathology. 2. ed. Philadelphia: W. B. Saunders Company, 1997.

BILBERG, $K$. et al. In vivo toxicity of silver nanoparticles and silver ions in Zebrafish (Danio rerio). Journal of toxicology, v. 2012, p. 293784, 2012.

BOBROV, K.; GUILLEMOT, L. Nanostructure formation by reactions of $\mathrm{H}_{2} \mathrm{O}$ with preadsorbed O on a Ag (110) surface. Surface Science, v. 601, n. 15, p. 3268-3275, 2007.

BOGGS, S.; LIVERMORE, D.; SELTZ, M. G. Humic substances in natural waters and their complexation with trace metals and radionuclides: a review. UNT Digital Library. Argonne, Illinois. Disponível em: <http://digital.library.unt.edu/ark:/67531/metadc282740/>.

BOLOGNESI, C. et al. Comet and micronucleus assays in zebra mussel cells for genotoxicity assessment of surface drinking water treated with three different disinfectants. The Science of the total environment, v. 333, n. 1-3, p. 127-36, 2004.

BOONSTRA, J.; POST, J. A. Molecular events associated with reactive oxygen species and cell cycle progression in mammalian cells. Gene, v. 337, p. 1-13, 2004. 
BUKHTIYAROV, V. I. et al. Atomic oxygen species on silver: Photoelectron spectroscopy and x-ray absorption studies. Physical Review B, v. 67, n. 23, p. 235422, 2003.

BURY, N. Metal contamination in aquatic environments: science and lateral management. Freshwater Biology, v. 54, n. 9, p. 2015-2015, 2009.

BUZEA, C.; PACHECO, I. I.; ROBBIE, K. Nanomaterials and nanoparticles: sources and toxicity. Biointerphases, v. 2, n. 4, p. MR17-R71, 2007.

CÁCERES-VÉLEZ, P. R. Uso de biomarcadores de genotoxicidade e histopatológicos para avaliação de toxicidade de vermiculita expandida magnética e vermiculita expandida em peixes Danio rerio. 2013.

CÁCERES-VÉLEZ, P. R. et al. Genotoxic and histopathological biomarkers for assessing the effects of magnetic exfoliated vermiculite and exfoliated vermiculite in Danio rerio. Science of The Total Environment, v. 551-552, p. 228-237, 2016.

$\mathrm{CAO}, \mathrm{S}$. et al. Synthesis and characterization of $\mathrm{CeO}_{2}$ and $\mathrm{ZnCeO}_{2}$ nanomaterials and exposure to photocatalytic activity. Journal of Materials Science: Materials in Electronics, v. 27, n. 2, p. 1873-1880, 2016.

CARRASCO, K. R.; TILBURY, K. L.; MYERS, M. S. Assessment of the piscine micronucleus test as an in situ biological indicator of chemical contaminant effects. Canadian Journal of Fisheries and Aquatic Sciences, v. 47, n. 11, p. 2123-2136, 1990.

CÉSAR, J.; AZEVEDO, R. DE. Análise de fluorescência de substâncias húmicas extraídas da água, solo e sedimento da lagoa dos patos - MS. Quim. Nova, v. 31, n. 6, p. 1324-1329, 2008.

CHAE, Y. J. et al. Evaluation of the toxic impact of silver nanoparticles on Japanese medaka (Oryzias latipes). Aquatic Toxicology, v. 94, n. 4, p. 320-327, 2009.

CHAKRABORTY, B. R. et al. TOF-SIMS and laser-SNMS investigations of dopant distribution in nanophosphors. Nanotechnology, v. 16, n. 8, p. 1006-1015, 2005.

CHEN, J. et al. Effect of silver nanoparticle dressing on second degree burn wound. Zhonghua wai ke za zhi, v. 44, n. 1, p. 50-2, 2006.

CHEN, Y. et al. Mitigation in multiple effects of graphene oxide toxicity in zebrafish embryogenesis driven by humic acid. Environmental Science and Technology, v. 49, n. 16, p. 10147-10154, 2015.

CHEN, Z. et al. Influence of humic acid on algal uptake and toxicity of ionic silver. Environmental Science and Technology, v. 47, n. 15, p. 8835-8842, 2013.

CHENG, J.; FLAHAUT, E.; CHENG, S. H. Effect of carbon nanotubes on developing zebrafish (Danio rerio) embryos. Environmental toxicology and chemistry / SETAC, v. 26, n. 4, p. 708-16, 2007. 
CHITHRANI, B. D.; GHAZANI, A. A.; CHAN, W. C. W. Determining the size and shape dependence of gold nanoparticle uptake into mammalian cells. Nano Letters, v. 6, n. 4, p. 662-668, 2006.

CHO, K. et al. Therapeutic nanoparticles for drug delivery in cancer. Clinical Cancer Research, v. 14, n. 5, p. 1310-1316, 2008.

CHOI, J. et al. Physicochemical Characterization and in vitro hemolysis evaluation of silver nanoparticles. Toxicological Sciences, v. 123, n. 1, p. 133-143, 2011.

CHOI, J. E. et al. Induction of oxidative stress and apoptosis by silver nanoparticles in the liver of adult zebrafish. Aquatic toxicology, v. 100, n. 2, p. 151-9, 2010.

COLLINS, A. et al. The comet assay: topical issues. Mutagenesis, v. 23, n. 3, p. 143-51, 2008.

CONG, Y. et al. Importance of Characterizing Nanoparticles before Conducting Toxicity Tests. Integrated Environmental Assessment and Management, v. 7, n. 3, p. 502-503, 2011.

CONWAY, J. R. et al. Aggregation, dissolution, and transformation of copper nanoparticles in natural waters. Environmental Science and Technology, v. 49, n. 5, p. 2749-2756, 2015.

DAI, L. et al. Influence of copper oxide nanoparticle form and shape on toxicity and bioaccumulation in the deposit feeder, Capitella teleta. Marine Environmental Research, v. 111, p. 99-106, 2015.

DASARI, T. P.; HWANG, H.-M. The effect of humic acids on the cytotoxicity of silver nanoparticles to a natural aquatic bacterial assemblage. The Science of the total environment, v. 408, n. 23, p. 5817-23, 2010.

DAUTREMEPUITS, C. et al. Humoral immune factors modulated by copper and chitosan in healthy or parasitised carp (Cyprinus carpio L.) by Ptychobothrium sp. (Cestoda). Aquatic toxicology, v. 68, n. 4, p. 325-38, 2004.

DEDAVID, B. A.; GOMES, C. I.; MACHADO, G. Microscopia eletrônica de varredura: Aplicações e preparação de amostras. Porto Alegre: EDIPUCRS, 2007.

DENG, S. et al. High-Throughput determination of statistical structure information for horizontal carbon nanotube arrays by optical imaging. Advanced Materials, v. 28, n. 10, p. 2018-2023, 2016.

DRAKE, P. L.; HAZELWOOD, K. J. Exposure-related health effects of silver and silver compounds: a review. The Annals of occupational hygiene, v. 49, n. 7, p. 575-85, 2005. 
DUFFIN, R. et al. Aluminium lactate treatment of DQ12 quartz inhibits its ability to cause inflammation, chemokine expression, and nuclear factor-kappaB activation. Toxicology and applied pharmacology, v. 176, n. 1, p. 10-7, 2001.

ESGUERRA-ARCE, A. et al. Influence of the Al content on the in vitro bioactivity and biocompatibility of PVD Ti1-xAxN coatings for orthopaedic applications. RSC Adv., v. 6, n. 65, p. 60756-60764, 2016.

ETHERIDGE, M. L. et al. The big picture on nanomedicine: The state of investigational and approved nanomedicine products. Nanomedicine: Nanotechnology, Biology, and Medicine, v. 9, n. 1, p. 1-14, 2013.

FABREGA, J. et al. Silver nanoparticle impact on bacterial growth: effect of $\mathrm{pH}$, concentration, and organic matter. Environmental science \& technology, v. 43, n. 19, p. 7285-90, 2009.

FABREGA, J. et al. Silver nanoparticles: Behaviour and effects in the aquatic environment. Environment International, v. 37, n. 2, p. 517-531, 2011.

FAN, W. et al. Effect of titanium dioxide nanoparticles on copper toxicity to Daphnia magna in water: Role of organic matter. Water Research, v. 105, p. 129-137, 2016.

FARMEN, E. et al. Acute and sub-lethal effects in juvenile Atlantic salmon exposed to low $\mu \mathrm{g} / \mathrm{L}$ concentrations of Ag nanoparticles. Aquatic Toxicology, v. 108, p. 78-84, 2012.

FENECH, M. et al. HUMN project: detailed description of the scoring criteria for the cytokinesis-block micronucleus assay using isolated human lymphocyte cultures. Mutation research, v. 534, n. 1-2, p. 65-75, 2003.

FILIPE, V.; HAWE, A.; JISKOOT, W. Critical evaluation of nanoparticle tracking analysis (NTA) by NanoSight for the measurement of nanoparticles and protein aggregates. Pharmaceutical Research, v. 27, n. 5, p. 796-810, 2010.

FLAK, D. et al. Tuning the photodynamic efficiency of $\mathrm{TiO}_{2}$ nanotubes against HeLa cancer cells by Fe-doping. RSC Adv., v. 5, n. 103, p. 85139-85152, 2015.

GAO, J. et al. Influence of Suwannee River humic acid on particle properties and toxicity of silver nanoparticles. Chemosphere, v. 89, n. 1, p. 96-101, 2012.

GARCÍA-ALONSO, J. et al. Toxicity and accumulation of silver nanoparticles during development of the marine polychaete Platynereis dumerilii. Science of the Total Environment, v. 476-477, p. 688-695, 2014.

GARNETT, M. C.; KALLINTERI, P. Nanomedicines and nanotoxicology: Some physiological principles. Occupational Medicine, v. 56, n. 5, p. 307-311, 2006. 
GEORGE, S. et al. Surface defects on plate-shaped silver nanoparticles contribute to its hazard potential in a fish gill cell line and Zebra fish embryos. ACS Nano, n. 5, p. 37453759, 2012.

GIANNOTTI, E. et al. A comparison of the in vitro Comet assay with the in vitro chromosome aberration assay using whole human blood or Chinese hamster lung cells: validation study using a range of novel pharmaceuticals. Mutagenesis, v. 17, n. 2, p. 163-70, 2002.

GIGUÈRE, A. et al. Influence of lake chemistry and fish age on cadmium, copper, and zinc concentrations in various organs of indigenous yellow perch (Perca flavescens). Canadian Journal of Fisheries and Aquatic Sciences, v. 61, n. 9, p. 1702-1716, 2004.

GISSELSSON, D. et al. Abnormal nuclear shape in solid tumors reflects mitotic instability. The American Journal of Pathology, v. 158, n. 1, p. 199-206, 2001.

GONTIJO, M. C.; MARQUES, Á.; TICE, R. Teste do cometa para a detecção de dano no DNA e reparo em células individualizadas. In: RIBEIRO, L.; SALVADORI, D.; MARQUES, E. (Eds.). Mutagênese Ambiental. Primera ed. Brasil. p. 247-279, 2003.

GREGUREC, D. et al. Stability of polyelectrolyte multilayers in oxidizing media: a critical issue for the development of multilayer based membranes for nanofiltration. Colloid and Polymer Science, v. 293, n. 2, p. 381-388, 2014.

GRIFFITT, R. J. et al. Exposure to copper nanoparticles causes gill injury and acute lethality in zebrafish (Danio rerio). Environmental science \& technology, v. 41, n. 23, p. 8178-86, 2007.

GRIFFITT, R. J. et al. Comparison of molecular and histological changes in zebrafish gills exposed to metallic nanoparticles. Toxicological Sciences, v. 107, n. 2, p. 404-415, 2009.

GROH, K. J. et al. Critical influence of chloride ions on silver ion-mediated acute toxicity of silver nanoparticles to zebrafish embryos. Nanotoxicology, v. 5390, p. 1-11, 2014.

GUNSOLUS, I. L. et al. Effects of humic and fulvic acids on silver nanoparticle stability, dissolution, and toxicity. Environmental Science \& Technology, v. 49, n. 13, p. 80788086, 2015.

GUO, J. Synchrotron radiation, soft-X-ray spectroscopy and nanomaterials. International Journal of Nanotechnology, v. 1, p. 193, 2004.

GUPTA, G. S.; DHAWAN, A.; SHANKER, R. Montmorillonite clay alters toxicity of silver nanoparticles in zebrafish (Danio rerio) eleutheroembryo. Chemosphere, v. 163, p. 242-251, 2016. 
GUSAIN, R. et al. Covalently attached graphene-ionic liquid hybrid nanomaterials: synthesis, characterization and tribological application. J. Mater. Chem. A, p. 1-12, 2016.

HAMMOCK, D. et al. The effect of humic acid on the uptake of mercury(II), cadmium(II), and zinc(II) by Chinook salmon (Oncorhynchus tshawytscha) eggs. Archives of environmental contamination and toxicology, v. 44, n. 1, p. 83-8, 2003.

HANAOR, D. et al. The effects of carboxylic acids on the aqueous dispersion and electrophoretic deposition of $\mathrm{ZrO}_{2}$. Journal of the European Ceramic Society, v. 32, n. 1, p. 235-244, 2012.

HANDY, R. D. et al. Ecotoxicity test methods for engineered nanomaterials: Practical experiences and recommendations from the bench. Environmental Toxicology and Chemistry, v. 31, n. 1, p. 15-31, 2012.

HASHIMOTO, Y. et al. Chemical speciation of silver (Ag) in soils under aerobic and anaerobic conditions: Ag nanoparticles vs. ionic Ag. Journal of Hazardous Materials, 2015.

HATCHETT, D. W.; WHITE, H. S. Electrochemistry of sulfur adlayers on the low-index faces of silver. The Journal of Physical Chemistry, v. 100, n. 23, p. 9854-9859, 1996.

HAVRDOVA, M. et al. Toxicity of carbon dots-Effect of surface functionalization on the cell viability, reactive oxygen species generation and cell cycle. Carbon, v. 99, p. 238248, 2016.

HENGLEIN, A. Colloidal silver nanoparticles: photochemical preparation and interaction with $\mathrm{O}_{2}, \mathrm{CCl}_{4}$, and Some metal ions. Chem. Mater., v. 2, n. 1, p. 444-450, 1998.

HENRY, T. B. et al. Attributing effects of aqueous C60 nano-aggregates to tetrahydrofuran decomposition products in larval zebrafish by assessment of gene expression. Environmental health perspectives, v. 115, n. 7, p. 1059-65, 2007.

HILL, A. J. et al. Zebrafish as a model vertebrate for investigating chemical toxicity. Toxicological sciences, v. 86, n. 1, p. 6-19, 2005.

HINTHER, A. et al. Nanometals induce stress and alter thyroid hormone action in amphibia at or below North American water quality guidelines. Environmental Science and Technology, v. 44, n. 21, p. 8314-8321, 2010.

HOFMANN, A. Spectroscopic techniques: I Spectrophotometric techniques. Principles and Techniques of Biochemistry and Molecular Biology, p. 477-521, 2010.

HOGSTRAND, C.; GALVEZ, F.; WOOD, C. M. Toxicity, silver accumulation and metallothionein induction in freshwater rainbow trout during exposure to different silver salts. Environmental Toxicology and Chemistry, v. 15, n. 7, p. 1102-1108, 1996. 
HOWE, K. et al. The zebrafish reference genome sequence and its relationship to the human genome. Nature, v. 496, n. 7446, p. 498-503, 2013.

HYUNG, H. et al. Natural organic matter stabilizes carbon nanotubes in the aqueous phase. Environmental science \& technology, v. 41, n. 1, p. 179-84, 2007.

ONG, K. J. et al. Humic acid ameliorates nanoparticle-induced developmental toxicity in zebrafish. Environmental Science: Nano, 2017.

JEYARAJ, M. et al. An investigation on the cytotoxicity and caspase-mediated apoptotic effect of biologically synthesized silver nanoparticles using Podophyllum hexandrum on human cervical carcinoma cells. Colloids and Surfaces B: Biointerfaces, v. 102, p. 708$717,2013$.

JEZIERSKA, B. The metal uptake and accumulation in fish living in polluted waters. Soil and Water Pollution Monitoring, Protection and Remediation, p. 107$114,2006$.

JIANG, W. et al. Nanoparticle-mediated cellular response is size-dependent. Nature nanotechnology, v. 3, n. 3, p. 145-50, 2008.

JO, H. J. et al. Acute toxicity of $\mathrm{Ag}$ and $\mathrm{CuO}$ nanoparticle suspensions against Daphnia magna: The importance of their dissolved fraction varying with preparation methods. Journal of Hazardous Materials, v. 227-228, p. 301-308, 2012.

JOHAL, M. S. Understanding Nanomaterials. CRC Press, 2011.

JOHNSTON, H.; CUTA, F.; GARRETT, A. The solubility of silver oxide in water, in alkali and in alkaline salt solutions. The amphoteric character of silver hydroxide. Journal of the American Chemical Society, p. 1930-1931, 1933.

JOVANOVIĆ, B.; WHITLEY, E. M.; PALIĆ, D. Histopathology of fathead minnow (Pimephales promelas) exposed to hydroxylated fullerenes. Nanotoxicology, v. 8, n. 7, p. 755-63, 2014.

KALBASSI, M. R.; SALARI-JOO, H.; JOHARI, A. Toxicity of silver nanoparticles in aquatic ecosystems: Salinity as the main cause in reducing toxicity. Iranian Journal of Toxicology, v. 5, n. 1, p. 436-443, 2011.

KETTLER, K. et al. Cellular uptake of nanoparticles as determined by particle properties, experimental conditions, and cell type. Environmental Toxicology and Chemistry, v. 33, n. 3, p. 481-492, 2014.

KHAN, F. R. et al. Accumulation dynamics and acute toxicity of silver nanoparticles to Daphnia magna and Lumbriculus variegatus: Implications for metal modeling approaches. Environmental Science and Technology, v. 49, n. 7, p. 4389-4397, 2015. 
KHATUN, Z. et al. Oral delivery of near-infrared quantum dot loaded micelles for noninvasive biomedical imaging. ACS Applied Materials and Interfaces, v. 4, n. 8, p. 3880-3887, 2012.

KIM, J. Y. et al. Developmental toxicity of Japanese medaka embryos by silver nanoparticles and released ions in the presence of humic acid. Ecotoxicology and environmental safety, v. 92, p. 57-63, jun. 2013a.

KIM, K.-T. et al. Silver nanoparticle toxicity in the embryonic zebrafish is governed by particle dispersion and ionic environment. Nanotechnology, v. 24, n. 11, p. 115101, 2013.

KIM, S. H. et al. Target-specific cellular uptake of PLGA nanoparticles coated with poly(Llysine)-poly(ethylene glycol)-folate conjugate. Langmuir, v. 21, n. 19, p. 8852-8857, 2005.

KIMURA, A.; MIYATA, A.; HONMA, M. A combination of in vitro comet assay and micronucleus test using human lymphoblastoid TK6 cells. Mutagenesis, v. 28, n. 5, p. 583-590, 2013.

KLASEN, H. . A historical review of the use of silver in the treatment of burns. II. Renewed interest for silver. Burns, v. 26, n. 2, p. 131-138, 2000.

KOSMEHL, T. et al. DNA damage induced by genotoxicants in zebrafish (Danio rerio) embryos after contact exposure to freeze-dried sediment and sediment extracts from Laguna Lake (The Philippines) as measured by the comet assay. Mutation research, v. 650, n. 1, p. 1-14, 2008.

KRISHNA, G.; HAYASHI, M. In vivo rodent micronucleus assay: protocol, conduct and data interpretation. Mutation research, v. 455, n. 1-2, p. 155-66, 2000.

KRISHNARAJ, C.; HARPER, S. L.; YUN, S.-I. In Vivo toxicological assessment of biologically synthesized silver nanoparticles in adult Zebrafish (Danio rerio). Journal of Hazardous Materials, v. 301, p. 480-491, 2016.

KRYSTEK, P. A review on approaches to bio distribution studies about gold and silver engineered nanoparticles by inductively coupled plasma mass spectrometry. Microchemical Journal, v. 105, p. 39-43, 2012.

KUKKONEN, J. et al. Effects of humus concentrations on benzo[a]pyrene accumulation from water to Daphnia magna: compaison of natural water sandstandard preparations. The Science of the Total Environment, v. 79, p. 197-207, 1989.

LAM, P. K. S.; GRAY, J. S. The use of biomarkers in environmental monitoring programmes. Marine pollution bulletin, v. 46, n. 2, p. 182-6, 2003. 
LAMMER, E. et al. Development of a flow-through system for the fish embryo toxicity test (FET) with the zebrafish (Danio rerio). Toxicology in vitro: An international journal published in association with BIBRA, v. 23, n. 7, p. 1436-42, 2009.

LANDGRAF, M. D. et al. Caracterização de ácidos húmicos de vermicomposto de esterco bovino compostado durante 3 e 6 meses. Quimica Nova, v. 22, n. 4, p. 483-486, 1999.

LECLERC, S.; WILKINSON, K. J. Bioaccumulation of nanosilver by Chlamydomonas reinhardtii - Nanoparticle or the free ion? Environmental Science and Technology, v. 48, n. 1, p. 358-364, 2014.

LEE, K. J. et al. In vivo imaging of transport and biocompatibility of single silver nanoparticles in early development of zebrafish embryos. ACS Nano, v. 1, n. 2, p. 133143, 2007.

LEE, K. J. et al. Single nanoparticle spectroscopy for real-time in vivo quantitative analysis of transport and toxicity of single nanoparticles in single embryos. The Analyst, v. 137, n. 13, p. 2973-86, 2012.

LEE, K. J. et al. Silver nanoparticles induce developmental stage-specific embryonic phenotypes in zebrafish. Nanoscale, v. 5, n. 23, p. 11625-36, 2013.

LEE, Y. J. et al. Ion-release kinetics and ecotoxicity effects of silver nanoparticles. Environmental Toxicology and Chemistry, v. 31, n. 1, p. 155-159, 2012.

LEVARD, C. et al. Environmental transformations of silver nanoparticles: Impact on stability and toxicity. Environmental Science and Technology, v. 46, n. 13, p. 69006914, 2012.

LI, X.; LENHART, J. J.; WALKER, H. W. Dissolution-accompanied aggregation kinetics of silver nanoparticles. Langmuir, v. 26, n. 22, p. 16690-16698, 2010.

LI, Y. et al. Molecular modeling of the relationship between nanoparticle shape anisotropy and endocytosis kinetics. Biomaterials, v. 33, n. 19, p. 4965-4973, 2012.

LIMPERT, E. et al. Log-normal distributions across the sciences: Keys and clues. BioScience, v. 51, n. 5, p. 341-352, 2001.

LIN, D. et al. The influence of dissolved and surface-bound humic acid on the toxicity of $\mathrm{TiO}_{2}$ nanoparticles to Chlorella sp. Water Research, v. 46, n. 14, p. 4477-4487, 2012.

LIN, P. C. et al. Techniques for physicochemical characterization of nanomaterials. Biotechnology Advances, v. 32, n. 4, p. 711-726, 2014.

LIN, S. et al. High Content screening in zebra fi sh speeds up hazard ranking of transition metal oxide nanoparticles. ACS nano, v. 5, n. 9, p. 7284-7295, 2011. 
LING, D.; HYEON, T. Chemical design of biocompatible iron oxide nanoparticles for medical applications. Small, v. 9, n. 9-10, p. 1450-66, 2013.

LITVIN, V.; GALAGAN, R.; MINAEV, B. Kinetic and mechanism formation of silver nanoparticles coated by synthetic humic substances. Colloids and Surfaces A: Physicochemical and Engineering Aspects, v. 414, p. 234-243, 2012.

LIU, J. et al. Controlled release of biologically active silver from nanosilver surfaces. ACS Nano, v. 4, n. 11, p. 6903-6913, 2010.

LIU, J.; HURT, R. Ion release kinetics and particle persistence in aqueous nano-silver colloids. Environmental science \& technology, v. 44, n. 6, p. 2169-2175, 2010.

LIU, Y. et al. Intracellular dynamics of cationic and anionic polystyrene nanoparticles without direct interaction with mitotic spindle and chromosomes. Biomaterials, v. 32, n. 32, p. 8291-8303, 2011.

LOK, C.-N. et al. Silver nanoparticles: partial oxidation and antibacterial activities. Journal of biological inorganic chemistry : JBIC, v. 12, n. 4, p. 527-34, 2007.

LÓPEZ-SERRANO, A. et al. Nanoparticles: a global vision. Characterization, separation, and quantification methods. Potential environmental and health impact. Analytical Methods, v. 6, n. 1, p. 38, 2014.

LÓPEZ-SERRANO, A. et al. Comparison of bioconcentration of ionic silver and silver nanoparticles in zebrafish eleutheroembryos. Environmental pollution, v. 191, p. 20714, 2014.

LUOMA, S. N. Silver nanotechnologies and the environment: Old problems or new challenges? Woodrow Wilson International Center of Scholars, 2008.

LUOMA, S. N.; HO, Y. B.; BRYAN, G. W. Fate, bioavailability and toxicity of silver in estuarine environments. Marine Pollution Bulletin, v. 31, n. 1-3, p. 44-54, 1995.

LUYTS, K. et al. How physico-chemical characteristics of nanoparticles cause their toxicity: complex and unresolved interrelations. Environmental Science-Processes \& Impacts, v. 15, n. 1, p. 23-38, 2013.

MA, X. et al. Interactions between engineered nanoparticles (ENPs) and plants: phytotoxicity, uptake and accumulation. The Science of the total environment, v. 408, n. 16, p. 3053-61, 2010.

MANOHARAN, V.; RAVINDRAN, A.; ANJALI, C. H. Mechanistic insights into interaction of humic acid with silver nanoparticles. Cell biochemistry and biophysics, v. 68, n. 1, p. 127-31, 2014.

MAO, Z. et al. Influence of structure and properties of colloidal biomaterials on cellular uptake and cell functions. Biomaterials Science, v. 1, n. 9, p. 896, 2013. 
MASSARSKY, A. et al. Assessment of nanosilver toxicity during zebrafish (Danio rerio) development. Chemosphere, v. 92, n. 1, p. 59-66, 2013.

MAYNARD, A. D. Estimating aerosol surface area from number and mass concentration measurements. Annals of Occupational Hygiene, v. 47, n. 2, p. 123-144, 2003.

MILLER, R. J. et al. $\mathrm{TiO}_{2}$ nanoparticles are phototoxic to marine phytoplankton. PloS one, v. 7, n. 1, 2012.

MIONE, M. C.; TREDE, N. S. The zebrafish as a model for cancer. Disease models \& mechanisms, v. 3, n. 9-10, p. 517-23, 2010.

MISRA, S. K. et al. The complexity of nanoparticle dissolution and its importance in nanotoxicological studies. The Science of the total environment, v. 438, p. 225-32, 1 nov. 2012.

MOHD OMAR, F.; ABDUL AZIZ, H.; STOLL, S. Aggregation and disaggregation of ZnO nanoparticles: Influence of $\mathrm{pH}$ and adsorption of Suwannee River humic acid. Science of The Total Environment, v. 468, p. 195-201, 2014.

MORGAN, T. P. et al. Time course analysis of the mechanism by which silver inhibits active $\mathrm{Na}^{+}$and $\mathrm{Cl}^{-}$uptake in gills of rainbow trout. Am. J. Physiol. Regul. Integr. Comp. Physiol., v. 1, p. 234-242, 2004.

MORONES, J. R.; ELECHIGUERRA, J. L. The bactericidal effect of silver nanoparticles. Nanotechnology, v. 16, n. 10, p. 2346-53, 2005.

MOSSELHY, D. A. et al. Silver nanoparticles: in vivo toxicity in zebrafish embryos and a comparison to silver nitrate. Journal of Nanoparticle Research, v. 18, n. 8, 2016.

MOULDER, J. F., STICKLE, W. F., SOBOL, P. E., \& BOMBEN, K. D. Handbook of X-ray Photoelectron Spectroscopy. Eden Prairie: Physical Electronics, 1995.

MOUSAVI, M. P. S. et al. Dynamic silver speciation as studied with fluorous-phase ionselective electrodes: Effect of natural organic matter on the toxicity and speciation of silver. Science of the Total Environment, v. 537, p. 453-461, 2015.

MURRAY, B. J. et al. Shape- and size-selective electrochemical synthesis of dispersed silver(l) oxide colloids. Nano Letters, v. 5, n. 11, p. 2319-2324, 2005.

MUTH-KOHNE, E. et al. The toxicity of silver nanoparticles to zebrafish embryos increases through sewage treatment processes. Ecotoxicology, 2013.

NAIR, R. et al. Nanoparticulate material delivery to plants. Plant Science, v. 179, n. 3, p. 154-163, 2010.

NAKAMOTO, K. Infrared and Raman Spectra of Inorganic and Coordination Compounds. Igarss, 2009. 
NAVARRO, E. et al. Toxicity of silver nanoparticles to Chlamydomonas reinhardtii. Environmental Science \& Technology, v. 42, n. 23, p. 8959-8964, 2008.

NAVARRO, E. et al. Effects of Differently Coated Silver Nanoparticles on the Photosynthesis of Chlamydomonas reinhardtii. Environmental Science and Technology, v. 49, n. 13, p. 8041-8047, 2015.

NEL, A. et al. Toxic potential of materials at the nanolevel. Science, v. 311, n. 5761, p. 622-7, 2006.

NOVAIS, R.F; ALVAREZ V., V.H.; BARROS, N.F. DE; FONTES, R.L.F.; CANTARUTTI, R.B.; NEVES, J. C. L. Fertilidade do solo. In: NOVAIS, R. F. DE et al. (Eds.). Matéria orgânica do solo. Viçosa, MG. p. 275-374.

NOWACK, B.; KRUG, H. F.; HEIGHT, M. 120 years of nanosilver history: Implications for policy makers. Environmental Science and Technology, v. 45, n. 4, p. 1177-1183, 2011.

NYLESE, T. Energy Dispersive Spectroscopy. second ed. Chichester: John Wiley \& Sons Ltd, 2015.

OBERDÖRSTER, G. et al. Principles for characterizing the potential human health effects from exposure to nanomaterials: elements of a screening strategy. Particle and fibre toxicology, v. 2, p. 8, 2005.

OBERDÖRSTER, G. Safety assessment for nanotechnology and nanomedicine: concepts of nanotoxicology. Journal of internal medicine, v. 267, n. 1, p. 89-105, 2010.

OBERDÖRSTER, G.; OBERDÖRSTER, E.; OBERDÖRSTER, J. Nanotoxicology: An emerging discipline evolving from studies of ultrafine particle. Environmental Health Perspective, v. 113, n. 7, p. 823-839, 2005.

OLIVEIRA, R. et al. Effects of triclosan on zebrafish early-life stages and adults. Environmental science and pollution research international, v. 16, n. 6, p. 679-88, 2009.

OLIVER, A. L. S. et al. Does water chemistry affect the dietary uptake and toxicity of silver nanoparticles by the freshwater snail Lymnaea stagnalis? Environmental Pollution, v. 189, p. 87-91, 2014.

OSBORNE, O. J. et al. Organ-Specific and size-dependent ag nanoparticle toxicity in gills and intestines of adult zebrafish. ACS Nano, v. 9, n. 10, p. 9573-9584, 2015.

OSTIGUY, C. et al. A good practice guide for safe work with nanoparticles: the Quebec Approach. Journal of Physics, v. 151, 2009. 
PAL, S.; TAK, Y. K.; SONG, J. M. Does the antibacterial activity of silver nanoparticles depend on the shape of the nanoparticle? A study of the gram-negative bacterium Escherichia coli. Journal of Biological Chemistry, v. 290, n. 42, p. 1712-1720, 2015.

PAN, G. H. et al. Preparation and characterization of decyl-terminated silicon nanoparticles encapsulated in lipid nanocapsules. Langmuir, v. 29, n. 41, p. 1268812696, 2013.

PARK, M. V. D. Z. et al. The effect of particle size on the cytotoxicity, inflammation, developmental toxicity and genotoxicity of silver nanoparticles. Biomaterials, v. 32, n. 36, p. 9810-7, 2011.

PARK, S. H. et al. Effects of silver nanoparticles on the fluidity of bilayer in phospholipid liposome. Colloids and Surfaces B: Biointerfaces, v. 44, n. 2-3, p. 117-122, 2005.

PATRI A, DOBROVOLSKAIA M, STERN S, MCNEIL S, A. M. Preclinical Characterization of Engineered Nanoparticles Intended for Cancer Therapeutics. In: AMIJI, M. M. (Ed.). Nanotechnology for Cancer Therapy. CRC Press, 2006. p. 105-137.

PELAZ, B. et al. Surface Functionalization of nanoparticles with polyethylene glycol: effects on protein adsorption and cellular uptake. ACS Nano, v. 9, n. 7, p. 6996-7008, 2015.

PETERSON, R. T.; MACRAE, C. A. Systematic approaches to toxicology in the zebrafish. Annual review of pharmacology and toxicology, v. 52, p. 433-53, jan. 2012.

POLITAKOS, N.; AZINAS, S.; MOYA, S. E. Responsive copolymer brushes of Poly[(2(Methacryloyloxy)Ethyl) Trimethylammonium Chloride] (PMETAC) and Poly(1H,1H,2H,2H-Perfluorodecyl acrylate) (PPFDA) to modulate surface wetting properties. Macromolecular Rapid Communications, v. 37, n. 7, p. 662-667, 2016.

POWERS, C. M. et al. Silver nanoparticles alter zebrafish development and larval behavior: Distinct roles for particle size, coating and composition. Neurotoxicology and Teratology, v. 33, n. 6, p. 708-714, 2011.

POWERS, K. W. et al. Research strategies for safety evaluation of nanomaterials. Part VI. characterization of nanoscale particles for toxicological evaluation. Toxicological Sciences, v. 90, n. 2, p. 296-303, 2006.

PRABHU, S.; POULOSE, E. K. Silver nanoparticles: mechanism of antimicrobial action, synthesis, medical applications, and toxicity effects. International Nano Letters, v. 2, n. 1, p. 32, 2012.

PSHYK, A. V. et al. High temperature behavior of functional TiAlBSiN nanocomposite coatings. Surface and Coatings Technology, v. 305, p. 49-61, 2016.

QIU, Y. et al. Surface chemistry and aspect ratio mediated cellular uptake of Au nanorods. Biomaterials, v. 31, n. 30, p. 7606-19, 2010. 
RATNER, B. D. Biomaterials Science: An Introduction to Materials in Medicine. San Diego: Academic Press, 1996.

REIDY, B. et al. Mechanisms of silver nanoparticle release, transformation and toxicity: A critical review of current knowledge and recommendations for future studies and applications. Materials, v. 6, n. 6, p. 2295-2350, 2013.

RODRIGUES, A. et al. Quantification of humic acids in surface water: Effects of divalent cations, $\mathrm{pH}$, and filtration. Journal of environmental monitoring: JEM, v. 11, n. 2, p. 377-82, 2009.

ROGERS, N. J. et al. The importance of physical and chemical characterization in nanoparticle toxicity studies. Integrated environmental assessment and management, v. 3, n. 2, p. 303-4, 2007.

SALEH, N. B.; PFEFFERLE, L. D.; ELIMELECH, M. Influence of biomacromolecules and humic acid on the aggregation kinetics of single-walled carbon nanotubes. Environmental Science and Technology, v. 44, n. 7, p. 2412-2418, 2010.

SANCHEZ, J. G. et al. Morphometric assessment of epidermal and mucous-biofilm changes caused by exposure of trout to chloramine-T or formalin treatment. Journal of comparative pathology, v. 118, n. 1, p. 81-7, 1998.

SAPSFORD, K. E. et al. Analyzing nanomaterial bioconjugates: A review of current and emerging purification and characterization techniques. Analytical Chemistry, v. 83, n. 12, p. 4453-4488, 2011.

SCHNITZER, M.; KHAN, S. U. Soil Organic Matter: Developments in Soil Science J3. New York: Elsevier Sci. Publ. Co., 1978.

SCHULTZ, A. G. et al. Aquatic toxicity of manufactured nanomaterials: Challenges and recommendations for future toxicity testing. Environmental Chemistry, v. 11, n. 3, p. 207-226, 2014.

SEITBAYEV, K. Z.; YESSIMSIITOVA, Z.; BAZARBAYEVA, M. Z. Histological Study of the Gills and gastrointestinal organs of the fishes, inhabiting the lake Bilikol. World Applied Sciences Journal, v. 25, n. 7, p. 1053-1056, 2013.

SHIN, J. T.; FISHMAN, M. C. From zebrafish to human: modular medical models. Annual review of genomics and human genetics, v. 3, n. 24, p. 311-40, 2002.

Silver in Drinking-water. Background document for development of WHO Guidelines for Drinking-water Quality.

SIMON-DECKERS, A. et al. Size-, composition- and shape-dependent toxicological impact of metal oxide nanoparticles and carbon nanotubes toward bacteria. Environmental Science and Technology, v. 43, n. 21, p. 8423-8429, 2009. 
SINGH, N. P. et al. A simple technique for quantitation of low levels of DNA damage in individual cells. Experimental Cell Research, v. 175, n. 1, p. 184-191, 1988.

SINGH, R.; NALWA, H. S. Medical applications of nanoparticles in biological imaging, cell labeling, antimicrobial agents, and anticancer nanodrugs. Journal of Biomedical Nanotechnology, v. 7, n. 4, p. 489-503, 2011.

SOTIRIOU, G. A. et al. Quantifying the origin of released $\mathrm{Ag}^{+}$ions from nanosilver. American Chemical Society, v. 28, p. 15929-15936, 2012.

SOTIRIOU, G.; PRATSINIS, S. Antibacterial activity of nanosilver ions and particles. Environmental science \& technology, v. 44, n. 14, p. 5649-5654, 2010.

STEVEnSON, F. J. Humus Chemistry: Genesis, Composition, Reactions. second ed. New York.

STOIBER, T. et al. Influence of hardness on the bioavailability of silver to a freshwater snail after waterborne exposure to silver nitrate and silver nanoparticles. Nanotoxicology, v. 9, n. 7, p. 918-27, 2015.

STUMm, W.; MORGan, J. J. Aquatic Chemistry: Chemical Equilibria and Rates in Natural Waters. 3rd Editio ed. Michigan: Environmental science and technology, 1995.

TAN, K. Humic matter in soil and the environment principles and controversies. New York: Marcel Dekker, Inc, 2003.

TAO, S. H. U. et al. Uptake of copper by neon tetras (Paracheirodon innesi) in the presence and absence of particulate and humic matter. Ecotoxicology, v. 8, p. 269-275, 1999.

TIEDE, K. et al. Considerations for environmental fate and ecotoxicity testing to support environmental risk assessments for engineered nanoparticles. Journal of Chromatography A, v. 1216, n. 3, p. 503-509, 2009.

TIPPING, E. Cation Binding by Humic Substances. UK: Cambridge University Press, 2005.

TORRES DE LEMOS, C. et al. River water genotoxicity evaluation using micronucleus assay in fish erythrocytes. Ecotoxicology and environmental safety, v. 66, n. 3, p. 391401, 2007.

TSANGARIS, C. et al. Genotoxicity and oxidative stress biomarkers in Carassius gibelio as endpoints for toxicity testing of Ukrainian polluted river waters. Ecotoxicology and environmental safety, v. 74, n. 8, p. 2240-4, 2011.

TURRENS, J. F. Mitochondrial formation of reactive oxygen species. The Journal of physiology, v. 552, p. 335-44, 2003. 
U.S. ENVIRONMENTAL PROTECTION AGENCY. Nanotechnology White Paper. Washington.

UNTERHALT, H.; RUPPRECHTER, G.; FREUND, H.-J. Vibrational sum frequency spectroscopy on $\mathrm{Pd}(111)$ and supported Pd nanoparticles: CO adsorption from ultrahigh vacuum to atmospheric pressure. J. Phys. Chem. B, v. 106, n. 2, p. 356-367, 2002.

\section{US EPA. National Recommended Water Quality Criteria.}

VAN GOETHEM, F.; LISON, D.; KIRSCH-VOLDERS, M. Comparative evaluation of the in vitro micronucleus test and the alkaline single cell gel electrophoresis assay for the detection of DNA damaging agents: genotoxic effects of cobalt powder, tungsten carbide and cobalt-tungsten carbide. Mutation research, v. 392, n. 1-2, p. 31-43, 1997.

VASQUEZ, M. Z. Combining the in vivo comet and micronucleus assays: a practical approach to genotoxicity testing and data interpretation. Mutagenesis, v. 25, n. 2, p. 187-99, 2010.

VOETS, J.; BERVOETS, L.; BLUST, R. Cadmium bioavailability and accumulation in the presence of humic acid to the zebra mussel, Dreissena polymorpha. Environmental Science \& Technology, v. 38, n. 4, p. 1003-8, 2004.

VÖLKER, C. et al. Toxicity of silver nanoparticles and ionic silver: Comparison of adverse effects and potential toxicity mechanisms in the freshwater clam Sphaerium corneum. Nanotoxicology, v. 5390, p. 1-9, 2014.

WAGNER, C. D. et al. Handbook of X-ray photoelectron spectroscopy. Minnesota: Perkin-Elmer Corporation, 1979.

WALKER, C. H. et al. Principles of Ecotoxicology. London: Taylor and Francis, 1996.

WANG, Z. et al. Humic substances alleviate the aquatic toxicity of polyvinylpyrrolidonecoated silver nanoparticles to organisms of different trophic levels. Environmental Toxicology and Chemistry, v. 34, n. 6, p. 1239-1245, 2015.

WANG, Z. et al. Toxicity assessment of precise engineered gold nanoparticles with different shapes in zebrafish embryos. RSC Adv., v. 6, n. 39, p. 33009-33013, 2016.

WARWICK, P. et al. Investigation of the permeability of humic molecules using zeta potential measurements. Chemosphere, v. 45, p. 303-307, 2001.

WIRTH, S. M.; LOWRY, G. V.; TILTON, R. D. Natural organic matter alters biofilm tolerance to silver nanoparticles and dissolved silver. Environmental Science and Technology, v. 46, n. 22, p. 12687-12696, 2012.

WOOD, C. M. et al. Bioavailability of silver and its relationship to ionoregulation and silver speciation across a range of salinities in the gulf toadfish (Opsanus beta). Aquatic toxicology, v. 70, n. 2, p. 137-57, 2004. 
WOOD, C. M.; PLAYLE, R. C.; HOGSTRAND, C. Physiology and modeling of mechanisms of silver uptake and toxicity in fish. Environmental toxicology and chemistry, v. 18, n. 1, p. 71-83, 1999.

XIU, Z. M. et al. Negligible particle-specific antibacterial activity of silver nanoparticles. Nano Letters, v. 12, n. 8, p. 4271-4275, 2012.

XIU, Z. M.; MA, J.; ALVAREZ, P. J. J. Differential effect of common ligands and molecular oxygen on antimicrobial activity of silver nanoparticles versus silver ions. Environmental Science and Technology, v. 45, n. 20, p. 9003-9008, 2011.

YAMAZAKI, M.; TANIZAKI, Y.; SHIMOKAWA, T. Silver and other trace elements in a freshwater fish, Carasius auratus langsdorfii, from the Asakawa river in Tokyo, Japan. Environmental pollution, v. 94, n. 1, p. 83-90, 1996.

YANG, H. N.; CHEN, H. C. Uptake and elimination of cadmium by Japanese eel, Anguilla japonica, at various temperatures. Bulletin of environmental contamination and toxicology, v. 56, n. 4, p. 670-6, 1996.

YANG, L. et al. Zebrafish embryos as models for embryotoxic and teratological effects of chemicals. Reproductive Toxicology, v. 28, n. 2, p. 245-253, 2009.

YANG, L.; ZHANG, L.; WEBSTER, T. J. Carbon nanostructures for orthopedic medical applications. Nanomedicine, v. 6, n. 7, p. 1231-44, 2011.

YANG, S. P. et al. Influence of humic acid on titanium dioxide nanoparticle toxicity to developing zebrafish. Environmental science \& technology, v. 47, p. 4718-4725, 2013.

YANG, X. et al. Silver nanoparticle behavior, uptake, and toxicity in Caenorhabditis elegans: Effects of natural organic matter. Environmental Science and Technology, v. 48, n. 6, p. 3486-3495, 2014.

YU, S.; YIN, Y.; LIU, J. Silver nanoparticles in the environment. Environmental Science: Processes \& Impacts, v. 15, n. 1, p. 78, 2013.

YUAN, H. et al. Variable nanoparticle-cell adhesion strength regulates cellular uptake. Physical Review Letters, v. 105, n. 13, 2010.

ZENG, H. C. Ostwald Ripening: A synthetic approach for hollow nanomaterials. Current Nanoscience, v. 3, p. 177-181, 2007.

ZHANG, H.; SMITH, J. A.; OYANEDEL-CRAVER, V. The effect of natural water conditions on the anti-bacterial performance and stability of silver nanoparticles capped with different polymers. Water Research, v. 46, n. 3, p. 691-699, 2012.

ZHANG, Y. et al. Impact of natural organic matter and divalent cations on the stability of aqueous nanoparticles. Water Research, v. 43, n. 17, p. 4249-4257, 2009. 
ZHAO, C. M.; WANG, W. X. Size-dependent uptake of silver nanoparticles in Daphnia magna. Environmental Science and Technology, v. 46, n. 20, p. 11345-11351, 2012.

ZHAO, T.; CHEN, K.; GU, H. Investigations on the interactions of proteins with polyampholyte-coated magnetite nanoparticles. Journal of Physical Chemistry B, v. 117, n. 45, p. 14129-14135, 2013.

ZHAO, X. et al. Evaluating the toxicity of hydroxyapatite nanoparticles in catfish cells and zebrafish embryos. Small, v. 9, n. 9-10, p. 1734-1741, 2013.

ZHAO, Y. et al. Interaction of mesoporous silica nanoparticles with human red blood cell membranes: size and surface effects. ACS Nano, v. 5, n. 2, p. 1366-75, 2011.

ZHOU, D.; KELLER, A. A. Role of morphology in the aggregation kinetics of ZnO nanoparticles. Water Research, v. 44, n. 9, p. 2948-2956, 2010.

ZHU, M. et al. Physicochemical properties determine nanomaterial cellular uptake, transport, and fate. Accounts of Chemical Research, v. 46, n. 3, p. 622-631, 2013.

$\mathrm{ZHU}, \mathrm{X}$. et al. The impact of $\mathrm{ZnO}$ nanoparticle aggregates on the embryonic development of zebrafish (Danio rerio). Nanotechnology, v. 20, n. 19, p. 195103, 2009.

ZIMMERMANN, S. et al. Trace analysis of platinum in biological samples: a comparison between sector field ICP-MS and adsorptive cathodic stripping voltammetry following different digestion procedures. Analytica Chimica Acta, v. 439, n. 2, p. 203-209, 2001. 
9.

$\mathbf{A}_{\text {Nexos }}$

\subsection{ANEXO A - DECLARAÇÃO DO COMITÊ DE ÉTICA NO USO DE ANIMAIS} (CEUA)

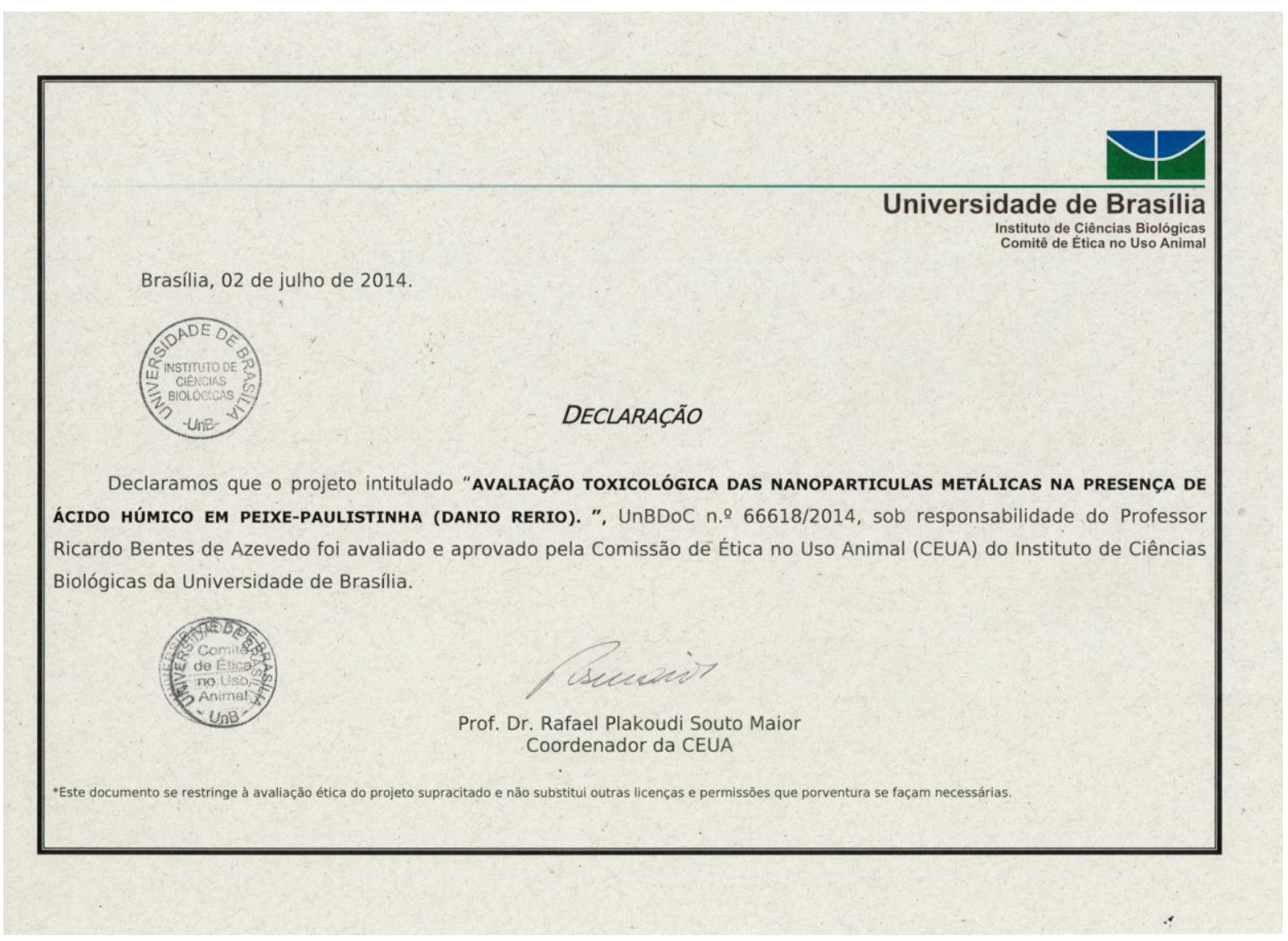




\subsection{ANEXO B - PARÂMETROS FÍSICO-QUÍMICOS DA ÁGUA NOS EXPERIMENTOS in vivo}

Parâmetros físico-químicos da água às 96 horas de exposição às nanopartículas de prata com e sem a presença de ácido húmico (20 mg/L). Testes de toxicidade em embriões e peixes adultos de zebrafish.

\begin{tabular}{|c|c|c|c|c|c|c|c|c|}
\hline \multicolumn{9}{|c|}{ PARÂMETROS FÍSICO-QUÍMICOS } \\
\hline $\begin{array}{c}\text { AgNP } \\
\text { (mg/L) }\end{array}$ & $\begin{array}{l}\text { Grupos de } \\
\text { exposição }\end{array}$ & $\begin{array}{c}\text { OXIGÊNIO } \\
\text { DISSOLVIDO } \\
\text { (ppm) }\end{array}$ & $\begin{array}{c}\text { NITRITOS } \\
\text { (ppm) }\end{array}$ & $\begin{array}{c}\text { AMONIA } \\
\text { (ppm) }\end{array}$ & $\begin{array}{c}\text { DUREZA } \\
\text { GH } \\
\text { (ppm) }\end{array}$ & pH & $\begin{array}{c}\text { COND. } \\
\left(\mu \mathrm{Scm}^{-1}\right)\end{array}$ & $\begin{array}{c}\text { TEMP. } \\
\left.\text { ( }{ }^{\circ} \mathrm{C}\right)\end{array}$ \\
\hline \multirow{2}{*}{0} & AgNP & 11,0 & nd & nd & 50 & 6,94 & 0,25 & 26 \\
\hline & $\mathrm{AgNP}+\mathrm{AH}$ & 8,0 & nd & 3,50 & 50 & 6,78 & 0,25 & 26 \\
\hline \multirow{2}{*}{0,25} & AgNP & 11,0 & nd & nd & 50 & 6,94 & 0,25 & 26 \\
\hline & $\mathrm{AgNP}+\mathrm{AH}$ & 8,0 & nd & 0,5 & 50 & 6,78 & 0,25 & 26 \\
\hline \multirow{2}{*}{0,5} & AgNP & 11,0 & nd & nd & 50 & 6,8 & 0,24 & 24 \\
\hline & $\mathrm{AgNP}+\mathrm{AH}$ & 8,0 & nd & 0,25 & 50 & 6,8 & 0,24 & 26 \\
\hline \multirow{2}{*}{1,0} & AgNP & 11,0 & nd & nd & 50 & 6,6 & 0,24 & 25 \\
\hline & $\mathrm{AgNP}+\mathrm{AH}$ & 8,0 & nd & 0,5 & 50 & 6,8 & 0,24 & 26 \\
\hline \multirow{2}{*}{1,5} & AgNP & & nd & nd & 50 & 6,8 & 0,24 & 25 \\
\hline & $\mathrm{AgNP}+\mathrm{AH}$ & 8,0 & nd & 0,25 & 50 & 7,0 & 0,24 & 25 \\
\hline \multirow{2}{*}{2,0} & AgNP & 11,0 & nd & nd & 50 & 6,8 & 0,24 & 26 \\
\hline & $\mathrm{AgNP}+\mathrm{AH}$ & 8,0 & nd & 0,25 & 50 & 7,0 & 0,24 & 25 \\
\hline \multirow{2}{*}{2,5} & AgNP & 11,0 & nd & nd & 50 & 6,8 & 0,24 & 25 \\
\hline & $\mathrm{AgNP}+\mathrm{AH}$ & 8,0 & nd & 0,5 & 50 & 6,8 & 0,24 & 26 \\
\hline \multirow{2}{*}{3,0} & AgNP & 11,0 & nd & nd & 50 & 6,6 & 0,24 & 25 \\
\hline & AgNP+AH & 8,0 & nd & 0,25 & 50 & 6,8 & 0,24 & 26 \\
\hline \multirow{2}{*}{4,75} & AgNP & 11,0 & nd & nd & 50 & 6,8 & 0,24 & 25 \\
\hline & $\mathrm{AgNP}+\mathrm{AH}$ & 8,0 & nd & 0,5 & 50 & 7,0 & 0,24 & 25 \\
\hline \multirow{2}{*}{6,5} & AgNP & 11,0 & nd & nd & 50 & 6,8 & 0,24 & 25 \\
\hline & $\mathrm{AgNP}+\mathrm{AH}$ & 8,0 & nd & 0,25 & 50 & 7,0 & 0,24 & 25 \\
\hline \multirow{2}{*}{8,5} & AgNP & 11,0 & nd & nd & 50 & 6,8 & 0,24 & 26 \\
\hline & $\mathrm{AgNP}+\mathrm{AH}$ & 8,0 & nd & 0,25 & 50 & 7,0 & 0,24 & 25 \\
\hline \multirow{2}{*}{10} & AgNP & 11,0 & nd & nd & 50 & 6,8 & 0,24 & 25 \\
\hline & $\mathrm{AgNP}+\mathrm{AH}$ & 8,0 & nd & 0,25 & 50 & 6,8 & 0,24 & 26 \\
\hline \multirow{2}{*}{20} & AgNP & 11,0 & nd & nd & 50 & 6,6 & 0,24 & 25 \\
\hline & $\mathrm{AgNP}+\mathrm{AH}$ & 8,0 & nd & 0,50 & 50 & 6,8 & 0,24 & 26 \\
\hline \multirow{2}{*}{30} & AgNP & 11,0 & nd & nd & 50 & 6,8 & 0,24 & 25 \\
\hline & $\mathrm{AgNP}+\mathrm{AH}$ & 8,0 & 0,25 & 0,50 & 50 & 7,0 & 0,24 & 25 \\
\hline \multirow{2}{*}{40} & AgNP & 11,0 & nd & nd & 50 & 6,8 & 0,24 & 25 \\
\hline & AgNP+AH & 8,0 & nd & 0,25 & 50 & 7,0 & 0,24 & 25 \\
\hline \multirow{2}{*}{60} & AgNP & 11,0 & nd & nd & 50 & 6,8 & 0,24 & 26 \\
\hline & $\mathrm{AgNP}+\mathrm{AH}$ & 8,0 & nd & 0,25 & 50 & 7,0 & 0,24 & 25 \\
\hline
\end{tabular}

COND.: condutividade, DUREZA GH: dureza geral, TEMP: temperatura, nd: não detectada. 